UNIVERSIDADE DE SÃO PAULO

MUSEU DE ARQUEOLOGIA E ETNOLOGIA

PROGRAMA DE PÓS-GRADUAÇÃO EM ARQUEOLOGIA

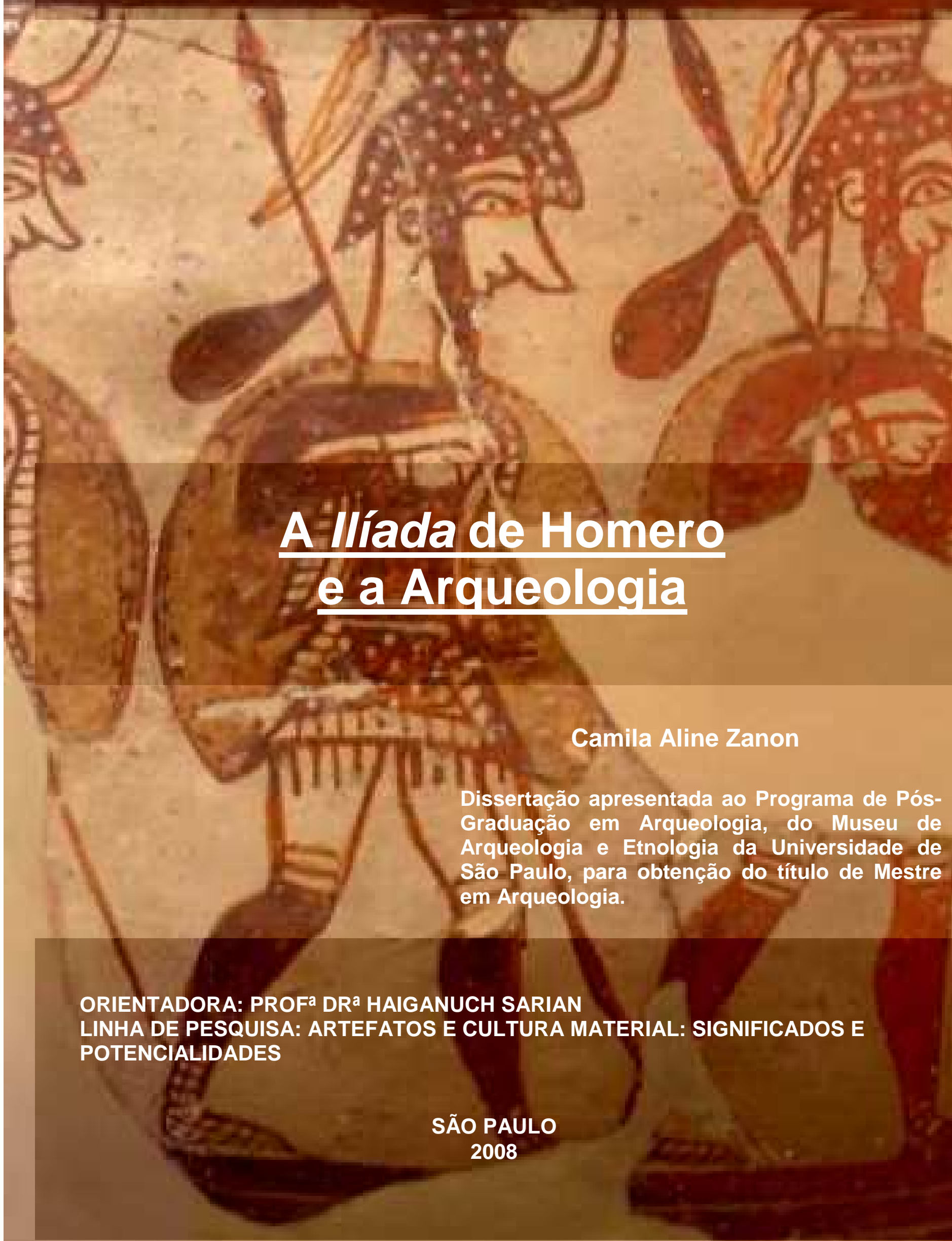




\section{A Ilíada de Homero e a Arqueologia}

Dissertação apresentada ao Programa de Pós-Graduação em Arqueologia no Museu de Arqueologia e Etnologia da Universidade de São Paulo para a obtenção do título de Mestre.

Orientadora: Profa. Dra . Haiganuch Sarian

São Paulo

2008 


\section{ERRATA}

Página Onde está Leia-se

$78 \quad$ Fig. $8 \quad$ Fig. 9

$79 \quad$ Fig. $9 \quad$ Fig. 10

$80 \quad$ Fig. $10 \quad$ Fig. 11

$81 \quad$ Fig. $11 \quad$ Fig. 12

Há duas páginas de número 139, mas não houve repetição do conteúdo nem prejuízo às referências a qualquer das duas páginas. 
A meus avós,

pelas memórias de uma infância feliz.

A meus tios,

pela generosidade e abnegação.

A meus pais, pela fé incondicional. 


\section{AGRADECIMENTOS}

Agradeço, em primeiro lugar, às pessoas sem as quais eu nunca teria chegado à Universidade de São Paulo: a meus pais que sempre apoiaram as minhas escolhas; à minha querida irmã Danieli, pelo respeito e admiração; a meus professores Sandra Bueno, José Barrios, Geraldo Teruya e Chico Néri, e a meus amigos Renan Carneiro, Lorena Carlson e Renata Monezzi, pessoas sem as quais as minhas escolhas não teriam sido as mesmas.

Aos meus amigos Alexandre Gomes e Adriana Cardoso, que me ajudaram a superar as dificuldades de viver numa cidade grande pela primeira vez e a enfrentar a maior universidade do país.

A Pedro Belasco, pelos mais de cinco anos de incentivo e cuidados dedicados a mim, por fazer da nossa convivência um processo cotidiano de aprendizado e superação.

Ao casal Izaura e Domingos Belasco e a Clóvis Ferreira, pessoas cujos limites da generosidade eu ainda não conheci.

A Luciano Ferreira, meu caro amigo platonista, por compartilhar muito mais do que a graduação em Grego Clássico, por transformar as coisas difíceis (ta/xal epa) em belas (ta/kal ay, e por ser a melhor companhia para os momentos de libação a Deméter.

A Tiago Attorre (Jerry), por fazer parte do conjunto de pessoas cuja generosidade não encontra limites.

À Lívia Oushiro, amiga querida de todas as horas (principalmente aquelas regadas a café e cigarro), a quem devo muito mais do que a revisão da dissertação; exemplo de objetividade e sobriedade.

A Gilberto da Silva Francisco, amigo querido, pela capa da presente dissertação, por algumas das fotos do capítulo 4, e principalmente por me ensinar a pensar arqueologicamente.

À Tatiana Bina, caríssima. Tati, você certamente também é um dos maiores ganhos desse mestrado. 
Ao Cláudio, Carol Guedes, Maria Fernanda e José Geraldo, colegas de MAE e de "Haiga".

À Carol Spinelli e Bernardo Goldberg, pela amizade sempre sincera.

À Sabrina Páscoli, Fabrício Barros e Caio Lorenzon, meus amigos incondicionais.

À Carla Hermann, minha querida amiga carioca.

Ao Irving Petrazzini (Genérico), responsável por grande parte da impressão da dissertação, por compartilhar o mesmo teto comigo e suportar minhas neuroses.

À generosidade e atenção de Nadia Gebara e Laila Spinelli.

À Erica Morais Angliker pela generosidade em compartilhar textos aos quais dificilmente eu teria acesso.

A JAA Torrano, a quem devo meus conhecimentos de Grego Antigo.

A André Malta pelo incentivo inicial para estudar Homero.

A Breno Batistini e a Daniel Rossi por transformarem o estudo de grego em uma tarefa gratificante e divertida.

A João Ângelo Oliva Neto, Marcos Martinho e Paulo Martins a quem devo meus conhecimentos de Latim.

Aos Vialou, que me deram a oportunidade de participar duas vezes (2007 e 2008) do estágio de campo na Cidade de Pedra (MT), fundamental para a minha formação em Arqueologia.

À Capes pelo financiamento.

Aos funcionários da biblioteca do MAE, por perdoar a minha falta de atenção com datas. E à Vanusa por sempre estar pronta a me ajudar com a burocracia.

Aos Profs. Drs. Christian Werner da Faculdade de Filosofia, Letras e Ciências Humanas da USP e Álvaro Allegrette da PUC por terem participado da banca de qualificação e contribuído com preciosas sugestões e cuidadosa leitura.

À minha orientadora Haiganuch Sarian por compartilhar toda a sua erudição com uma generosidade rara em pesquisadores de sua estatura.

E finalmente, mas não menos importante, a Uiran Gebara da Silva por ler minha dissertação, acompanhar passo a passo a sua confecção e estar sempre disposto a ser meu interlocutor mesmo nas horas em que as palavras me fugiam. 


\section{Resumo}

\section{ZANON, C. A. A llíada de Homero e a Arqueologia.}

2008. Dissertação (Mestrado). Museu de Arqueologia e Etnologia, Universidade de São Paulo, São Paulo, 2008.

A llíada de Homero é geralmente caracterizada como um poema que trata da Guerra de Tróia, que teria acontecido mais de 500 anos antes da composição de tal poema, e teria sido transmitido através da tradição oral, até o momento em que foi escrito pela primeira vez. Esperava-se, portanto, que os fatos narrados pelo poeta correspondessem aos achados arqueológicos encontrados para o Período Micênico, mas o que se encontra na llíada é uma mistura de elementos da sociedade micênica e da sociedade contemporânea a Homero, ou seja, o século VIII a.C. O estudo da relação entre documentos arqueológicos dos períodos Micênico, Proto-Geométrico e Geométrico, compreendidos entre 1550 e o final do século VIII a.C., e a llíada de Homero é composto por duas categorias de fontes distintas, a arqueológica e a escrita, esta como resultado de uma tradição oral que a precedeu. A presente dissertação tem como foco apresentar as informações que se podem depreender da llíada de Homero que, de alguma forma, contribuíram para a interpretação arqueológica e se, de tal confronto, surgiram controvérsias entre os dois tipos de fontes, levando a uma reflexão sobre a questão da continuidade e da ruptura de elementos culturais próprios da Civilização Micênica e que, de certa maneira, se refletem nos períodos posteriores em pauta.

Palavras-chave: Homero, Ilíada, Arqueologia, Idade do Bronze, Idade do Ferro. 


\section{Abstract}

\section{ZANON, C. A. The lliad of Homer and Archaeology.}

2008. Dissertation (Master). Museum of Archaeology and Ethnology, University of São Paulo, São Paulo, 2008.

The Iliad of Homer is generally seen as a poem about the Trojan War, which took place more than 500 years before the composition of such poem, and transmitted by oral tradition down to the moment it was written for the first time. It was hoped, therefore, that the facts narrated by its poet matched the archaeological finds for the Mycenaean Period; instead what is found in the lliad is an ensemble of the elements of the Mycenaean society and the one contemporary to Homer, which is considered to be the eighth century B.C. The study of the relation between the Mycenaean, Proto-Geometrical, and Geometrical archaeological finds, dating from 1550 to the end of the eighth century B.C., and the lliad of Homer is based on two different categories of sources, namely the archaeological and the literary ones, the last one being the result of an oral tradition which had preceded it. The present dissertation focuses on showing the information that can be derived from the lliad of Homer that somehow has contributed to the archaeological interpretation and whether controversies were raised between those two kinds of sources from such a comparison, leading to a reflection about the question of either continuity or rupture of the cultural elements proper to the Mycenaean Civilization and that, in a certain way, are reflected on the later periods concerned.

Keywords: Homer, Iliad, Archaeology, Bronze Age, Iron Age. 


\section{Sumário}

Introdução

Capítulo 1 - Homero, Schliemann, Tróia e Micenas:

a história de uma descoberta 16

1.1 A descoberta de Tróia: um breve histórico 21

1.2 Tirinto e Micenas 31

Capítulo 2 - Blegen e Wace em Tróia e Micenas:

o desenvolvimento de uma arqueologia 55

2.1 Tsountas em Micenas 56

2.2 Wace em Micenas, Blegen em Tróia 59

2.3 Blegen em Pilos $\quad 62$

2.4 Wace retorna a Micenas 63

2.5 Ventris, Chadwick e a Linear B 65

2.6 O estado da arte em Micenas $\quad 67$

2.7 O estado da arte em Tróia 69

2.8 Ahhiyawa e Wilusa: intersecções $\quad 71$

Capítulo 3 - Funerais $\quad 82$

3.1 Culto Tumular X Culto Heróico ou Culto Heróico $\cap$ Culto Tumular? 88

3.2 Reminiscências da Era Heróica na Arte Figurativa do Século VIII a.C.: pintores ilustrando Homero? $\quad 91$

3.3 Considerações Finais 96

Capítulo 4 - Armas $\quad 98$

4.1 Armas Defensivas 101

4.1.1 Cnêmides 101

4.1.2 Armadura e Couraça 109

4.1.3 Elmo 112 
4.1.4 Escudo 116

4.2 Armas Ofensivas 122

4.2.1 Espada 122

4.2.2 Lança e Dardo 128

4.2.3 O Arco e a Flecha 131

4.2.4 Carro 134

$\begin{array}{ll}4.3 \text { Considerações Finais } & 137\end{array}$

Capítulo 5 - “Arqueologia Homérica?”:

os desencontros de uma disciplina 159

5.1 Poesia homérica: tradição oral > fonte textual 160

5.2 Fonte textual $X$ fonte material ou fonte textual $\cap$ fonte material? 161

5.3 As expectativas arqueológicas em relação ao poema homérico: passado, $\begin{array}{ll}\text { presente e futuro } & 164\end{array}$

5.4 A impertinência do termo "Arqueologia Homérica" 168

$\begin{array}{ll}\text { Bibliografia } & 171\end{array}$

Fontes Literárias 184

Lista de Figuras $\quad 186$

Lista de Websites 192

ANEXOS

Anexo I - Mapa elaborado por Daphne Kleps (Reed College) 193

Anexo II - Mapa com a proveniência dos heróis homéricos 194

Anexo III - Sítios da Idade do Bronze que apresentam palácios 195

Anexo IV - Tabela Cronológica 196 


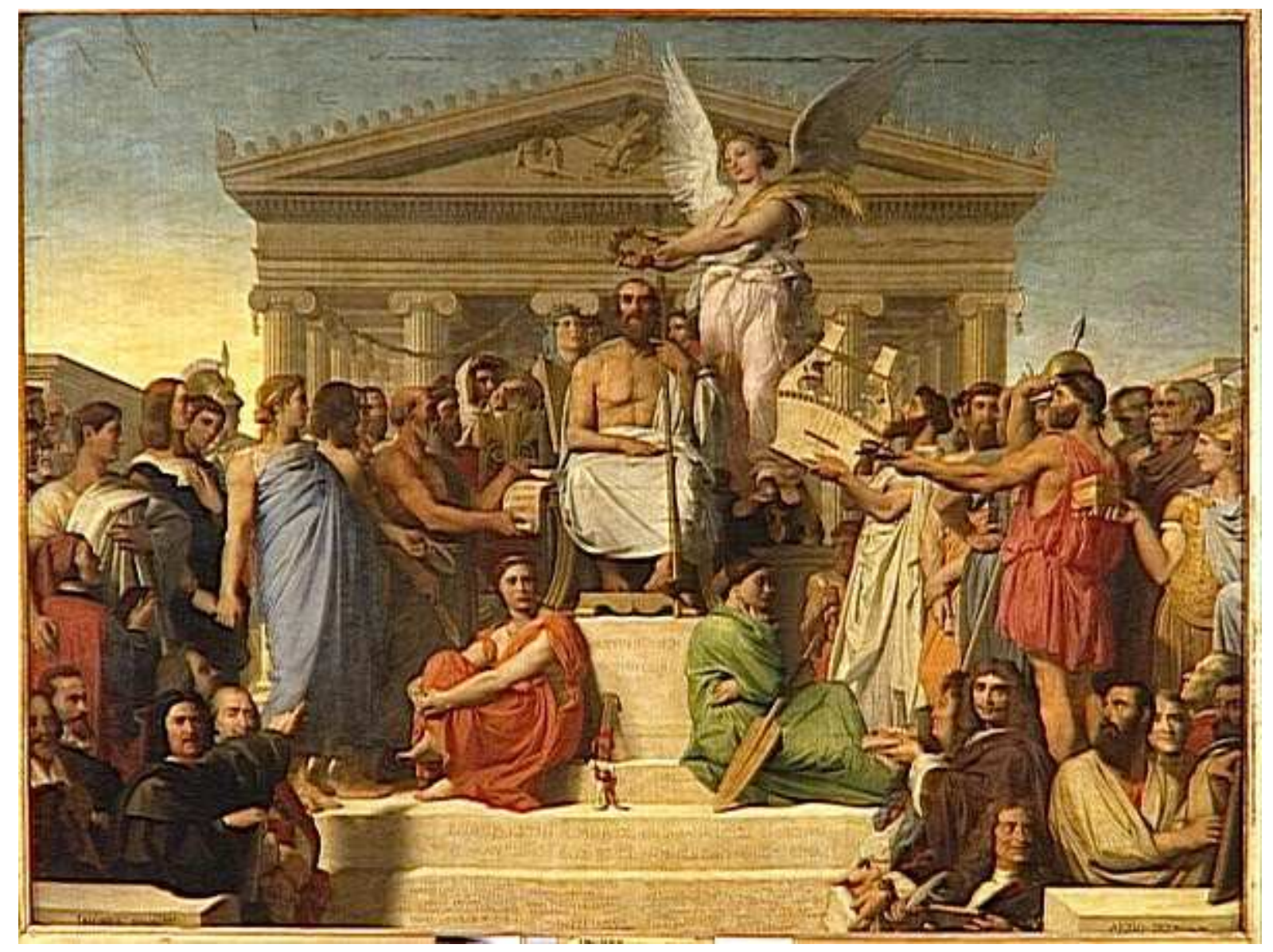

INTRODUCÃO 
"O fato e a verdade têm pouco em comum."

Paul Verlaine.

Gostaria de iniciar essa introdução com um tom bastante ensaístico expondo algumas das embaraçosas perguntas que os meus colegas, sabendo que eu me dedicava aos estudos da relação entre a llíada e a Arqueologia, dirigiram-me durante o período que dediquei à confecção dessa dissertação de mestrado; não porque elas me foram feitas por colegas que, em geral, são estudantes de História, Letras, Filosofia e Arqueologia, mas pelo embaraço de me sentir compelida a respondê-las, quando muitas delas ainda não apresentam uma resposta ou apresentam muitas: "Homero realmente existiu?" "Quando a llíada foi composta?" "Foi Homero mesmo quem a compôs?" "Se ela não foi composta por Homero, mas sim organizada aos poucos no curso de várias centenas de anos, então foi Homero quem a compilou?" "Se ela foi composta oralmente, quem e quando a escreveu?" "Quem a escreveu a modificou?" "O seu conteúdo é histórico ou apenas mitológico?" "O que a Arqueologia tem a ver com a llíada?" "Tróia realmente existiu? Mas não disseram que a cidade que aquele alemão maluco descobriu na verdade não é Tróia?”; “Tróia fica na Turquia?!? Mas não fica na Grécia?”

Por trás dessas perguntas aparentemente infantis, residem as questões fundamentais dos estudos homéricos. E, para começar a compreender as possibilidades de respostas para tais perguntas, é mister definir de antemão qual o sentido do adjetivo 'homérico' que será utilizado nessa dissertação. Desde a descoberta da Civilização Micênica durante o final do século XIX, quando se percebeu que a llíada e a Odisséia continham elementos de tal civilização, o termo 'Civilização Homérica' passou a ser usado como sinônimo para a 'Civilização Micênica'. Somente com o avanço nos estudos arqueológicos durante o século XX e o avanço dos estudos homéricos (aqueles concernentes à llíada e à Odisséia) é que essas duas civilizações deixaram de ser igualadas e o anacronismo foi, aos poucos, sendo desfeito. Portanto, o adjetivo 'homérico' somente será utilizado nessa dissertação no que concerne aos poemas épicos atribuídos a Homero, a saber, a Ilíada e a Odisséia. O termo 'Arqueologia Homérica', por conseguinte, receberá a sua devida revisão crítica no capítulo final da presente dissertação. 
Apesar de todos os esforços de estudiosos de diversas partes do mundo, a nuvem cinzenta em torno da entidade "Homero" ainda existe. Não se sabe ao certo se ele realmente existiu; isso a Arqueologia ainda não conseguiu descobrir e os textos ainda não proporcionaram uma resposta definitiva. A questão da existência ou não de Homero é uma preocupação moderna, e não antiga, pois os antigos não tinham dúvida de que ele realmente existiu (eles tinham a llíada e a Odisséia como provas conclusivas disso). Existe até mesmo um busto de Homero (Fig. 1) de época romana esculpido em mármore; evidentemente, este busto não nos apresenta como Homero foi, mas como um artista do período romano o idealizou.

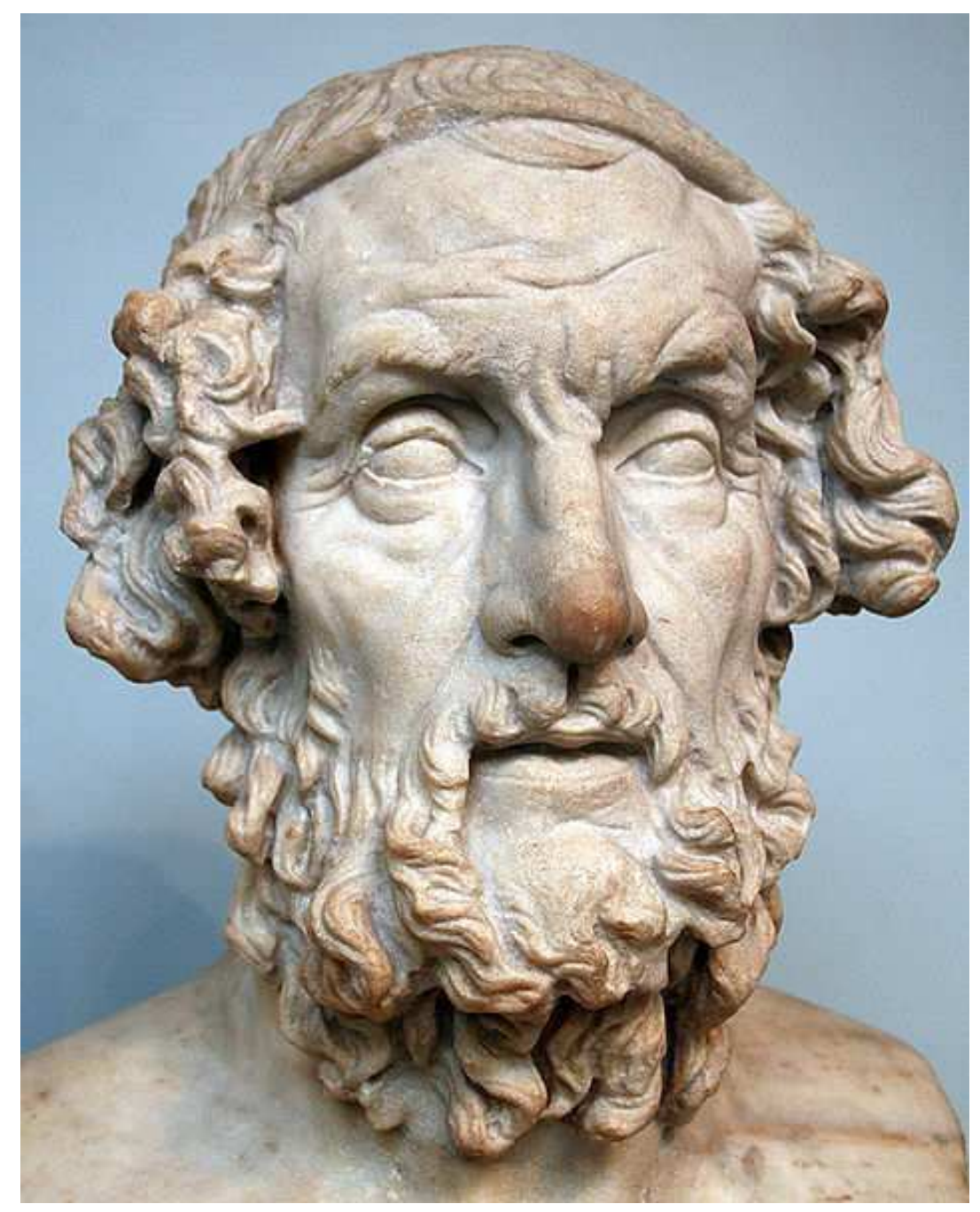

Fig. 1. Busto de Homero esculpido em mármore. Cópia romana datada dos séculos I-II d.C. de um suposto original do Período Helenístico (século II a.C.). Proveniente de Baiae, Campânia, Itália. Museu Britânico. Fonte da Figura: http://en.wikipedia.org/wiki/lmage:Homer British Museum.jpg. último acesso em 04 dez 2008. 
Embora seja um salto gigantesco partir dos primeiros séculos da nossa era, data proposta para o busto de Homero, para o século XVIII, gostaria de discorrer um pouco sobre o quadro no frontispício da presente introdução. O pintor francês Ingres (1780-1867), que considerava a si mesmo um 'pintor da história', presenteou-nos com um quadro, atualmente exposto no Museu do Louvre em Paris, denominado 'A apoteose (ou deificação) de Homero'. Neste, Homero portando um cetro ocupa um trono numa posição central no quadro ao ser coroado pela deusa Vitória. Não pretendo explorar toda a simbologia presente no quadro, mas é possível ver o poeta Píndaro the oferecendo uma lira e dentre as várias figuras presentes nessa cerimônia estão figuras humanas de várias épocas diferentes (observe nos cantos inferiores). A cena se passa diante de uma construção cujas características estilísticas são greco-romanas, e o mais curioso no quadro certamente são as figuras humanas nos cantos inferiores que olham para fora do quadro na direção de seu pintor ou de seu espectador; um deles aponta para Homero num gesto de quem está mostrando ou apresentando algo. Sem dúvida, o caráter anacrônico do quadro de Ingres não o priva de se constituir como obra de arte e, mais do que isso, confere a Homero a magnanimidade de ser glorificado através de subseqüentes e diferentes eras, chegando a ponto de ser transformado em divindade por Ingres. Se Ingres falhou em fornecer um retrato exato de Homero, não sabemos, mas certamente não falhou em representar a sua magnitude e imortalidade como poeta através dos tempos. O quadro de Ingres não representa Homero, mas a grandeza da qual ele gozava na época do pintor nos meios letrados.

Se a questão da existência ou não de Homero está bem longe de ser resolvida, é melhor partir de coisas e para coisas cuja existência não seja questionável: a llíada e a Odisséia. Ainda que Homero não tenha nunca existido, temos hoje, no século XXI, duas obras literárias, pertencentes ao gênero épico e que foram atribuídas a ele durante toda a Antiguidade e essa tradição ainda perdura. E mesmo que voltemos as nossas costas para a questão da existência ou não de Homero, a pergunta que recai sobre o momento em que ela foi composta persiste. Embora as datas ainda sejam controversas, elas não seriam anteriores ao meio do 
século VIII a.C. e não seriam posteriores à metade do século VI a.C. ${ }^{1} \mathrm{~A}$ resposta a essa questão também envolve a existência de uma tradição que antecedia a sua fixação e, sem dúvida, a data dessa fixação em forma de texto escrito.

A questão que envolve o caráter histórico ou mitológico de seu conteúdo também deve ser explorado cuidadosamente, pois a distinção entre o que é fato e o que não o é não consiste numa preocupação inerente ao texto homérico e, portanto, não se deve cobrar dele tal distinção. Isso é ponto pacífico. De qualquer maneira, o século XIX procurava o seu caráter histórico, e um alemão trouxe à luz algo que lhe conferia certa historicidade: um monte composto de escombros de uma cidade enterrada na planície da Anatólia, bem próximo ao estreito de Dardanelos, onde se supunha estar Tróia, a cidade que emprestou seu nome à poesia e que esta lhe retribuiu com a eternidade. O século XX precisava entender essa historicidade $\mathrm{e}$ explicá-la, e um século inteiro de escavações e intensos estudos do material arqueológico foi dedicado a entender as partes que constituíam os estudos dos textos homéricos e sua relação com a Grécia Pré-histórica, que passou a ser protohistórica, pois a escrita Linear B foi decifrada e se tornou parte integrante dos estudos da Civilização Micênica e também refletiu nos estudos dos textos homéricos como testemunhos de tal civilização. A Arqueologia também mostrou como as práticas que eram estranhas a tal civilização, como a cremação do morto, também estavam presentes na narrativa homérica, tornando-a uma 'colcha de retalhos' cujos fios e frações pertenciam a diferentes épocas. Mas em que medida é possível utilizar a llíada de Homero como fonte histórica? Descartá-la totalmente simplesmente por ser uma obra poética e não histórica é jogar o bebê com a água do banho, pois ela ainda é a nossa fonte mais antiga sobre a Guerra de Tróia; todas as outras referências são posteriores a ela.

O estranhamento sobre a localização de Tróia é perdoável em absoluto; fomos educados com a frase "a llíada é a primeira obra da literatura ocidental".2

\footnotetext{
${ }^{1}$ As discussões acerca da data mais provável para a composição desses poemas, mais especificamente o caso da Ilíada, serão apresentadas no capítulo final.

2 À parte os dois anacronismos expressos pelos termos 'ocidental', que certamente não assumia tal conotação na Antiguidade, e 'literatura', cujo conceito é ocidental e pressupõe as letras, ou seja, uma forma escrita de texto. Como as obras homéricas são o resultado de uma composição oral, não seria mais apropriado referir-se à Ilíada como a primeira obra poética ao invés de 'literária'?
} 
Como esperar ou acreditar que Tróia não fique na Europa? Assim como a questão do caráter histórico/mitológico da poesia, noções que não fazem parte do universo que esse poema reflete ou em que ele emerge, o conceito de Europa é também estranho a ele e, não menos, o termo Grécia. Mas é possível descartá-los? Se sim, teríamos de substituí-los, mas quais seriam os termos apropriados? Não pretendo responder a essa pergunta exatamente, pois fugiria do escopo da dissertação, mas isso não me impede de colocar a questão de outra maneira de forma a poder transformá-la numa questão cuja abordagem não é fácil, mas está dentro do limite temático proposto: Existiu ou existe uma Grécia Homérica? Estaria Tróia dentro dela?

Para entender melhor a construção do conhecimento acerca do conteúdo da Ilíada no que concerne à cultura material que ela evoca, o primeiro capítulo fará uma breve exposição do histórico das descobertas durante o século XIX e suas principais figuras responsáveis. O segundo capítulo se ocupará em continuar esse histórico no século XX com a organização e sistematização do material disponível, além das descobertas que continuaram a ser realizadas, mas, agora, institucionalmente através dos centros de estudos de nacionalidades diversas que convergiram para a Grécia em busca de suas origens (e somente de suas origens?). O terceiro capítulo discorrerá sobre os funerais apresentados na llíada e sua relação com a cultura material quanto às práticas mortuárias, o culto heróico e as representações vasculares durante o século VIII a.C. O quarto capítulo será um estudo das armas em Homero e seus paralelos ou contradições em relação à cultura material. E, finalmente, o capítulo cinco consistirá numa tentativa de realizar uma reflexão sobre a impertinência do termo "Arqueologia Homérica" e sobre as expectativas arqueológicas em relação ao texto homérico. 


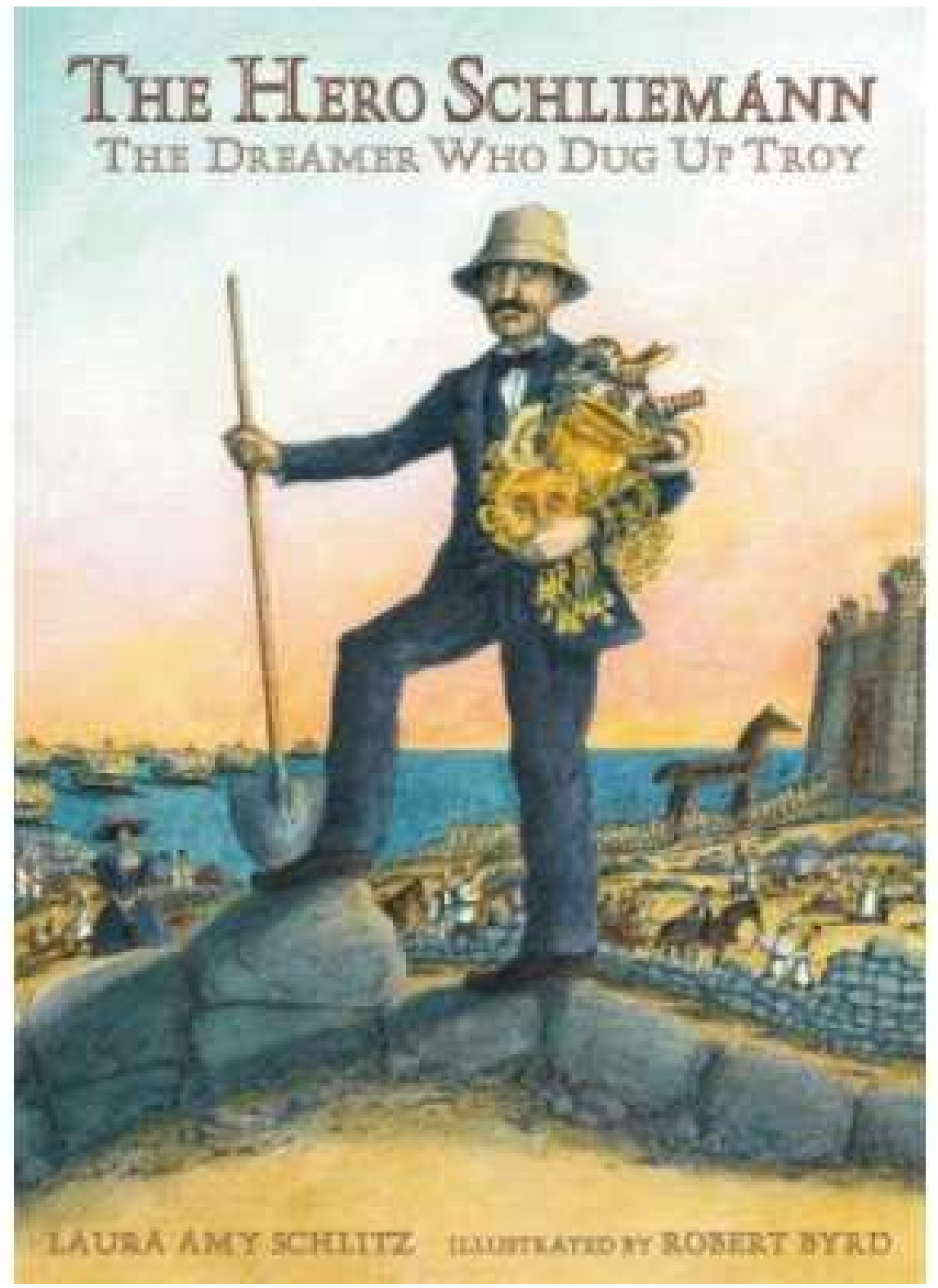

Capítulo 1

Schliemann, Homero, Tróia e Micenas: a história de uma descoberta 
... mas onde busquei os muros de Tróia,

quietas ovelhas pastam e o cágado se arrasta.

Lord Byron, Don Juan, 1819-1824.

Enquanto as raças de ouro e de prata, às quais faz referência Hesíodo (séc. VIII-VII a.C.) entre os versos 109-142 de Os trabalhos e os dias, ainda permanecem sob o véu do mito e nada mais são para nós do que manifestações míticas do pensamento antigo, sem nenhuma raiz na realidade histórica, as raças de bronze e de ferro já nos foram descortinadas e ganharam o aval da existência, passando, assim, a fazer parte dos nossos conhecimentos atestados arqueologicamente sobre a Proto-história egeana e Idade do Ferro Antiga. Agora, ela conserva para nós uma reminiscência da Idade do Bronze durante a qual viveu a raça dos heróis, aquela cujos ciclos épicos conservaram uma lembrança mais precisa e sobre a qual se debruçaram os poetas trágicos atenienses e poetas líricos, como Píndaro. Esta passagem definitiva de "mito" para a existência se deve principalmente a um alemão que viveu na segunda metade do século XIX, chamado Heinrich Schliemann. Até então, os conhecimentos sobre a Grécia referentes às épocas anteriores às obras de Homero e Hesíodo eram limitados aos textos daqueles poetas líricos ou trágicos que utilizaram os ciclos épicos, de poetas épicos de épocas tardias que trataram da viagem dos Argonautas ou que desenvolveram o ciclo troiano, de historiadores e mitólogos ${ }^{1}$ que amiúde sobreviveram aos mais de dois mil anos que nos separam da Antigüidade, sendo Homero a fonte mais antiga.

As próprias obras de Homero (e aqui o problema da autoria ou da unidade não se faz relevante) eram ora creditadas como possuidoras de um caráter histórico, ora destituídas deste, mas ainda permaneciam como sendo a fonte mais completa da época dos heróis, ou seja, dos dois últimos séculos da Idade do Bronze.

\footnotetext{
${ }^{1}$ A História de Heródoto (séc. V a.C.) oferece preciosas observações sobre cronologia; a História da Guerra do Peloponeso de Tucídides (séc. V-IV a.C.) é iniciada por uma Arqueologia que remonta à guerra de Tróia; a Bibliotheca, atribuída a Apolodoro (séc. II a.C.), é um resumo de todo o ciclo épico depois da criação dos deuses até a morte de Odisseu e o retorno dos Heráclidas; Diodoro da Sicília (séc. I a.C.) iniciou sua Bibliotheca Historica desde as épocas "mitológicas"; a obra do geógrafo Estrabão (séc. I a.C.- I d.C.) é rica em observações sobre etnografia Pré-helênica; Pausânias (séc. II d.C.) em sua Periegesis se refere a elementos míticos e legendários. Antes das descobertas de Heinrich Schliemann essas eram as principais fontes que poderiam ser utilizadas para se obter informações sobre a Idade do Bronze e a Idade do Ferro.
} 
Uma das grandes questões impostas pela curiosidade de qualquer leitor de Homero, além da existência ou não de Tróia, era sobre o "quando", ou seja, se a Guerra de Tróia realmente aconteceu, quando aconteceu? Heródoto (II, 145) nos diz que Pan, que é um pouco posterior à guerra de Tróia, viveu por volta de 800 anos antes da época do próprio Heródoto:

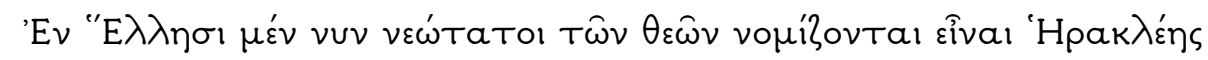

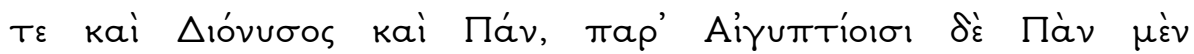

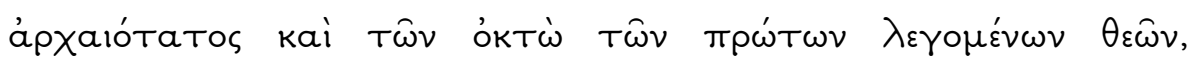

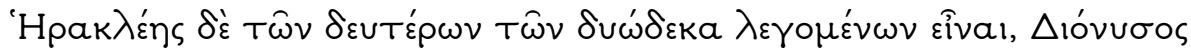

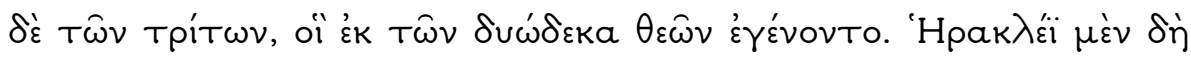

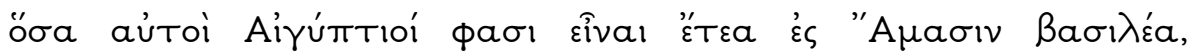

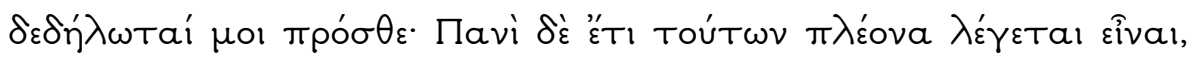

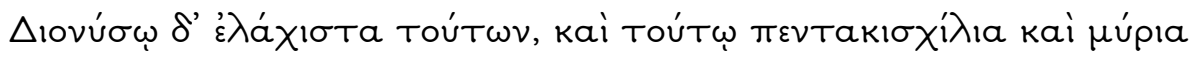

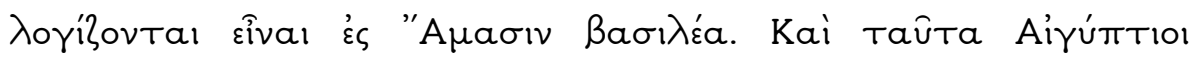

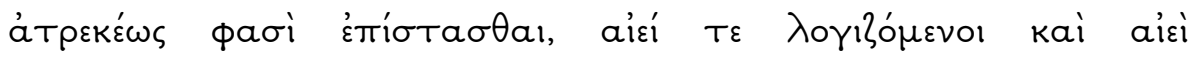

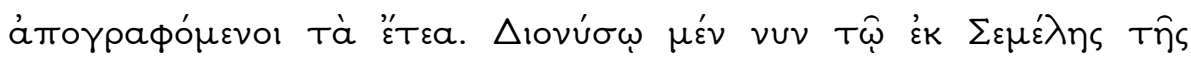

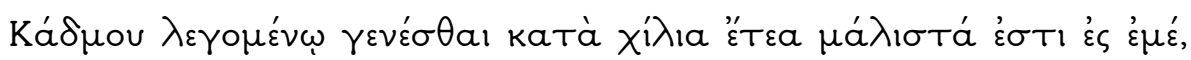

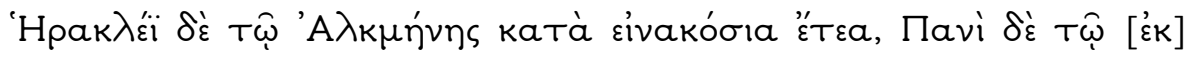

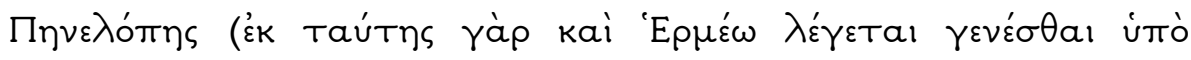

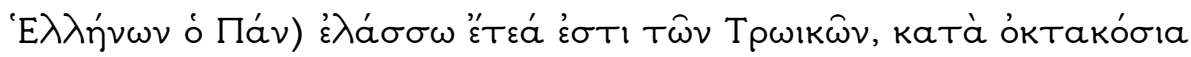

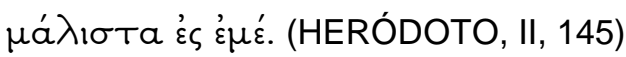

Para os gregos, os mais novos dentre os deuses costumam ser Héracles, Dioniso e Pan. Para os egípcios, Pan é o mais antigo e está dentre os deuses da ogdóade, ditos primordiais; Héracles está dentre os da segunda [dinastia] com 12 deuses; e Dioniso, dentre os da terceira, que nasceram dos 12 deuses. Os próprios egípcios dizem com exatidão quantos anos há entre o reinado de Amásis e Héracles, mostrado por mim anteriormente. Para Pan diz-se haver mais anos, e para Dioniso, menos anos. Para este, 15.000 anos calculam haver até o reinado de Amásis. Os egípcios, sempre calculando e registrando os anos, afirmam genuinamente conhecê-los. Dizse [entre os gregos] que Dioniso, nascido de Sêmele, filha de Cadmo, é mil anos aproximadamente anterior a mim; Héracles, filho de Alcmena, cerca de 900 anos; e Pan, filho de Penélope (pois desta e de Hermes dizem ter nascido entre os helenos), contemporâneo à Guerra de Tróia, é cerca de 800 anos anterior a $\mathrm{mim}^{2}$

\footnotetext{
${ }^{2}$ Tradução própria a partir do texto estabelecido por Ph.-E. Legrand, publicado na coleção Les Belles Lettres. (para a referênica completa da obra, ver a seção Fontes Literárias ao fim da dissertação).
} 
Como Heródoto viveu no século $V$ a.C., isso nos permite calcular a data da guerra de Tróia por volta de 1250 a.C.; curiosamente, esta é aproximadamente a data proposta por Blegen (1971), após as escavações no sítio de Tróia realizadas na década de 1930, para a destruição de Tróia VIla, que corresponde atualmente à Tróia homérica.

Tucídides (I, xii, 3) fixa em 60 anos após a destruição de Tróia a instalação dos beócios nos entornos de Tebas e 80 anos depois da mesma guerra a invasão do Peloponeso pelos dórios, embora ele não estabeleça nenhuma data para a captura de Tróia:

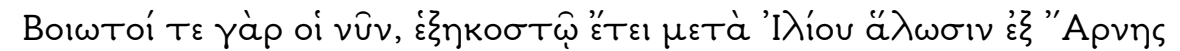

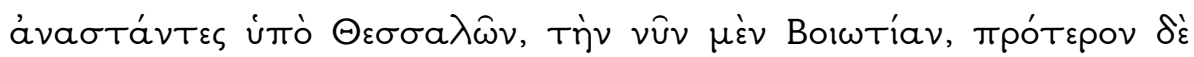

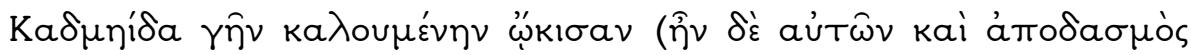

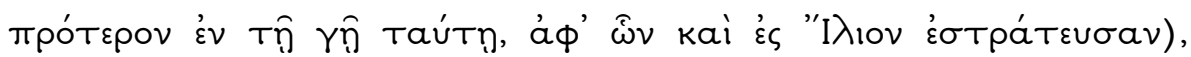

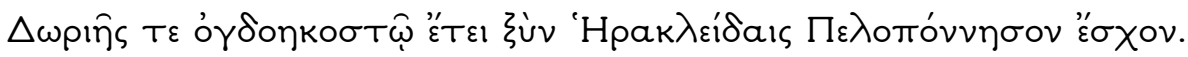
(TUCÍDIDES, l, xii, 3)

Foi o caso dos beócios de hoje, que, sessenta anos após a tomada de Tróia, desalojados de Arne pelos tessálios, fixaram-se na terra que hoje se chama Beócia e antes Cadmeida (já antes existia nessa terra um núcleo deles de onde partiram os que fizeram a campanha contra ĺlio); e também os dórios, oitenta anos após a mesma data, juntamente com os Heraclidas se apossaram do Peloponeso. (Trad. de Ana Lia Amaral, 1999, p.19)

A Grécia antiga nos deixou várias cronologias; uma das mais antigas é a cronologia gravada sobre o Mármore de Paros ${ }^{3}$ redigida em 264 a.C., que dá uma lista de datas a partir do reinado de Cecrops, primeiro rei de Atenas, em 1582 a.C.; ela data o cerco a Tróia em 1218-1207 a.C. ${ }^{4}$

\footnotetext{
af" ouk oil [ ElIh]nej eil Troian elst]rateus[an], elh RHHHHRIIII, basil eubntoj A gh[nw Men]es qewj treiskaidekatou etouj.
}

\footnotetext{
${ }^{3}$ Disponível em <http://www.ashmolean.museum/ash/faqs/q004/>. Último acesso em 09/05/2007.

${ }^{4}$ Disponível em $<$ http://www.ashmolean.museum/ash/faqs/q004/q004010.html $>$. Último acesso em 08/05/2007.
} 
De quando os [Hele]nos m[ar]char[am] contra Tróia, 954 anos, durante o 13 ano do reinado de [Men]esteu, rei de Ate[nas].

(Tradução própria)

O sábio alexandrino Eratóstenes de Cirene (276-194 a.C. $)^{5}$, em sua obra Chronographiai, diz que a guerra de Tróia aconteceu 80 anos antes do retorno dos Heráclidas:

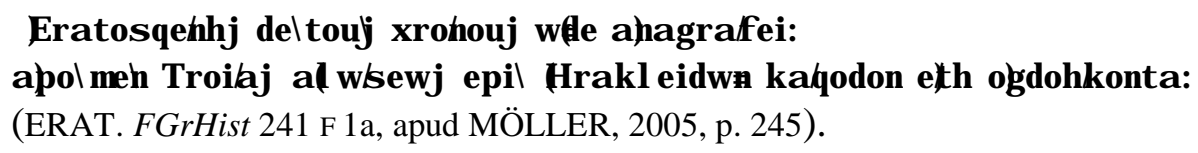

Eratóstenes registra os tempos como segue:

A partir da captura de Tróia até o retorno dos Heráclidas oitenta anos;

(Tradução própria)

A data do retorno dos Heráclidas é elucidada em uma passagem de Heródoto. Essa passagem diz que Leônidas, rei de Esparta, e seu irmão Cleômenas, que reinaram no início do século $V$ a.C., ocupavam a $15^{a}$ geração a partir de Eurístenes, um dos Heráclidas responsáveis pela reconquista do Peloponeso (HERÓDOTO, VII, 204). Segundo Burn (1935, p. 130), baseando-se na soma de 40 anos para cada geração, Eratóstenes datou o retorno dos Heráclidas em 600 anos antes de Cleômenas (40 anos multiplicados por 15 gerações resultam em 600 anos). Assim Eratóstenes estabeleceu a data do retorno dos Heráclidas em 1104 a.C., mas esse retorno se deu duas gerações (ou 80 anos) após a guerra de Tróia, portanto, a data para tal guerra seria 1184 a.C.

Apolodoro (séc. II a.C.) em sua Bibliotheca retomou as datas estabelecidas por Eratóstenes (BURN, 1935, p. 131 nota 2). Diodoro da Sicília (séc. I a.C.), por sua vez, em sua Bibliotheca Historica, utilizou as datas oferecidas por Apolodoro. Castor de Rodes (séc. I a.C.), contemporâneo de Diodoro, em seu tratado sobre talassocracias, que se inicia com a guerra de Tróia, cita a data de 1194-1185 a.C

\footnotetext{
${ }^{5}$ A obra de Eratóstenes que fornece uma cronologia de eventos desde a Guerra de Tróia até a sua época, não sobreviveu ao tempo. O que restou são excertos de sua autoria presentes em obras de outros autores que o retomaram. Alguns trechos dessa obra podem ser encontrados em Clinton, Henry Fynes, Fasti Hellenici: a Civil and Literary Chronology of Greece, 4 vols. (1824-34) (vol. i. pp. 3, 408). Disponível em: $<$ http://www.perseus.tufts.edu/cgibin/ptext?doc=Perseus\%3Atext\%3A1999.04.0062\%3Aid\%3Deratosthenes $>$. Último acesso em 29/05/2007.
} 
para tal evento, ${ }^{6}$ e provavelmente se utilizou das mesmas fontes de Diodoro.

Eusébio, bispo de Cesaréia, viveu entre o fim do século III e o início do IV da nossa era e nos deixou uma das cronologias mais completas existentes, ${ }^{7}$ que começa em 2015 a.C. com Europs, rei de Sicione; ele também situa a tomada de Tróia em 1184 a.C., ou seja, a mesma data citada por Eratóstenes (MYRES, 1906, p. 108). Como se pode ver, Eusébio se utilizou de Diodoro, que se utilizou de Apolodoro, que, por sua vez, se utilizou de Eratóstenes, e assim, a data em torno de 1184 a.C. foi repetidamente assumida para a guerra de Tróia durante grande parte da Antiguidade.

Pode-se notar, portanto, que as diferenças entre as datas propostas pelos autores antigos são relativamente próximas, sendo 1250 a.C. a mais antiga e 1184 a.C. a mais recente; o intervalo entre as datas propostas para a queda de Tróia e para as invasões dóricas corresponde aproximadamente às datas que vieram a ser confirmadas pela arqueologia ao longo do século XX.

\subsection{A descoberta de Tróia: um breve histórico}

A cidade de Ílion (ou llium) fora considerada durante a Antigüidade como o local da antiga cidade de Príamo e o curso da tradição confirmava essa identidade. A visita de Xerxes (c. 519-465 a.C.) durante o ano de 480 a.C. foi imortalizada por Heródoto (VII, 43), e a visita de Alexandre (356-323 a.C.) em 334 a.C. por Plutarco (Alexandre, XV, 4-5) e pelo próprio Cícero (106-43 a.C.) numa passagem de seu Pró Árquias (X, 24). Lucano (séc. I d.C.) em sua Farsália (IX, 964 ss.) conta sobre a visita de Júlio César a Tróia. Germânico (15 a.C.-19 d.C.) visitou Tróia em 18 d.C. (Tácito, Anales, II, 54) e, ao lado do túmulo de Heitor, escreveu um poema contando

\footnotetext{
${ }^{6}$ Alguns fragmentos de Castor de Rodes constam da edição Didot de Heródoto, à qual não tive acesso: Herodotus. Herodoti Historiarum libri IX / recognovit et commentationem de dialecto Herodoti praemisit Guilielmus Dindorfius. Ctesiae Cnidii et chronographorum, castoris, ratosthenis, etc. fragmenta / dissertatione et notis illustrata a Carolo Müllero ; graece et latine cum indicibus. -- Parisiis : A.F. Didot, 1855.

${ }^{7}$ Eusébio de Cesaréia: P a nt oda ph/ /s t ori la, dividido em duas partes: a primeira que ele denominou X r onogra fía onde relata a origem e a história de todas as nações e impérios desde a criação do mundo até o ano de 325 d.C.; a segunda parte, intitulada X r oni k of K a nw h, consistia de tabelas sincrônicas, dando num período de a cada dez anos os nomes dos soberanos e os principais eventos, desde o chamado de Abraão (2017 a.C.). A obra em grego foi perdida, mas existe uma versão em armênio.
} 
a ele que os romanos, descendentes de Enéas, teriam vingado a sua morte (Anthologia Latina, I, pt. li, № 708). Esse poema foi traduzido para o grego pelo imperador Adriano (76-138 d.C.), que visitou Tróia no século II d.C. (Anthologia Palatina, IX, 387). ${ }^{8}$ Apolônio de Tyana (2 a.C. - c. 98 d.C.) passou uma noite no túmulo de Aquiles, segundo Filóstrato (Life of Apollonius of Tyana, iv, 11-12.). $\mathrm{O}$ imperador Caracala (186-217 d.C.) organizou uma espécie de romaria a Tróia e lá realizou as honras fúnebres de um liberto chamado Festo com direito a jogos e prêmios, como no funeral de Pátroclo (Herodian, IV, viii, 4-5).

Todas essas visitas ilustres não tornaram a geografia homérica um assunto menos polêmico. Demétrio de Scepsis, no século II a.C., comparando os dados geográficos presentes em Homero à geografia local, sustentava que sua cidade natal de Scepsis fora a residência de Enéas. Ele, então, lançou a afirmação de que Ílion e seus arredores não tinham espaço suficiente para os grandes feitos da llíada, que a planície que separava a cidade do mar teria sido um território aluvial e que não estava formada até depois da guerra de Tróia. Como uma outra prova de que a localização das duas cidades não poderia ser a mesma, ele diz que Aquiles e Heitor tinham dado três voltas em torno de Tróia e não era possível percorrer esse trajeto em torno de Ílion por causa de sua geografia. Por todas essas razões ele propôs que a antiga Tróia se localizava na "Vila dos Ilianos", a quase cinco quilômetros (5 km) de ílion, embora ele tenha sido obrigado a reconhecer que não havia restado nenhum traço da cidade nesse local (MAHAFFY, 1882, passim). Demétrio fora a principal fonte do geógrafo Estrabão (Ibidem, p. 69) para tal assunto, embora ele tenha encontrado inconsistências e contradições em Demétrio com relação a Homero. Parece que o próprio Estrabão não visitara a Trôade, nem mesmo Pausânias que, infelizmente, não disse muito sobre essa região.

Os primeiros viajantes da Renascença, ${ }^{9}$ acompanhados de suas bagagens literárias acerca de Tróia, identificaram as ruínas de Alexandria Troas como Ílion e visitavam com grande emoção as ruínas do "Palácio de Príamo", na verdade, um banho público de período romano. Georges Sandys, entretanto, em 1610, rejeitou

\footnotetext{
${ }^{8}$ Existe incerteza sobre a autoria e a tradução do poema.

${ }^{9} \mathrm{O}$ grande salto da Antiguidade para a Renascença encontra sua justificativa na ausência de fontes que apresentem a questão da incerteza ou não sobre a localidade de Tróia.
} 
Alexandria Troas como a cidade dos poemas homéricos porque pensava que as ruínas estavam muito próximas ao mar, não fornecendo campo suficiente para as ações da llíada (SPENCER, 1957, p. 84). Essa afirmação dava início ao método de comprovação topográfica dos detalhes da llíada e, durante o curso do século XVII, a identificação de Alexandria Troas como Ílion aos poucos foi abandonada, embora a geografia de Tróia e seus arredores não recebesse mais esclarecimentos.

No século XVIII, o poeta britânico Alexander Pope (1688-1744) publicou uma tradução da llíada para o idioma inglês e junto com ela um mapa da Trôade a partir de informações topográficas que ele depreendeu do próprio poema (p. 37, fig. 1). Embora a disposição dos rios Escamandro e Simoente estivesse invertida (erro que Pope atribuiu à tipografia), durante a maior parte do século XVIII esse era o único mapa disponível aos leitores de Homero.

Robert Wood (1717-1771), considerado o 'avô' da questão homérica por ter sido o primeiro a questionar o conhecimento da escrita por parte de Homero, publicou um outro mapa (fig. 2) após ter viajado pela Trôade com Homero em punho. Seu mapa mostrava mais detalhes do que o mapa de Pope, mas omitia uma informação muito importante: a cidade de Tróia. Essa omissão se deve ao fato de Wood não ter encontrado a cidade de Tróia na planície troiana e, portanto, não saber onde colocá-la em seu mapa.

O antropólogo britânico Richard Pancocke (1704-1765) viajou pela Trôade por volta de 1740 e em sua obra A Description of the East, and Some other Countries, de 1743, considerou o monte de Hissarlik como a antiga Tróia (apud SPENCER, 1957, p. 87, nota 73). ${ }^{10}$ Mas foi a publicação de Voyage dans la Troade, ou tableau de la plaine de Troie dans son état actuel (1791) de Lechevalier (1752-1836), publicada depois que visitara a planície troiana em 1788, que atraiu maior atenção dos interessados em assuntos homéricos. Uma das evidências mais importantes para a determinação do sítio de Tróia eram as fontes do rio Escamandro. Havia duas suposições contraditórias, ambas fornecidas por Homero, sobre as quais se apoiavam os inquiridores da geografia homérica: o Monte Ida ou as duas fontes, uma quente, outra fria, que descreve Homero numa passagem do canto XXII da

\footnotetext{
${ }^{10}$ Pancocke, Richard. A Description of the East, and Some other Countries, 1743, II, pt.ii, p. 106-8.
} 
Ilíada, entre os versos 147-156, quando Aquiles está perseguindo Heitor ao redor de Tróia:

\begin{abstract}
os mananciais cristalinos passaram, que as duas nascentes perenemente alimentam do Xanto de vortices túrbidos: de uma, água quente deflui, de onde denso vapor se levanta continuamente, tal como se fogo vivaz a aquecesse, enquanto da outra, até mesmo no ardor do verão, sempre escoa água tão gélida quanto granizo ou cristais de alva neve. Junto das fontes, cavados na pedra, mui belos e largos, viam-se os tanques que outrora as esposas e as filhas dos Teucros para lavar seus brilhantes vestidos usavam, no tempo em que reinava ainda, paz, anterior à chegada dos Dânaos. (Trad. Carlos Alberto Nunes, 1996, $6^{a}$ ed.)
\end{abstract}

Quando Lechevalier estava explorando a Trôade, seu guia the contou haver uma fonte quente nas proximidades de Bunarbashi, treze quilômetros $(13 \mathrm{~km})$ ao sul do Estreito de Dardanelos. Ele logo presumiu que aquela era uma das fontes do Escamandro, que Bunarbashi era Tróia, e que o monte rochoso (Bali Dagh) que havia atrás de Bunarbashi era a própria Pérgamo de Príamo. Mas em 1801, Edward Daniel Clarke (1769-1822) visitou as fontes que havia nas proximidades com um termômetro e demonstrou que não havia grande variação de temperatura entre elas (apud SPENCER, 1957, p. 89) ${ }^{11}$ e propôs a vila de Chiblak, a pouco mais de três quilômetros $(3 \mathrm{~km}$ ) de Hissarlik, como possível localização de Ílion (apud ibidem, p. 93, nota 98). ${ }^{12}$ Havia ainda outro argumento contra a teoria de Bunarbashi-Tróia; Heitor e Aquiles correram em volta de Tróia três vezes (mesmo argumento utilizado por Demétrio de Scepsis, no século II d.C., para invalidar a cidade de Ílion como provável Tróia; supra), feito impossível dada a geografia do monte Bali Dagh, pois suas faces sul e sudoeste caíam como um precipício até o vale do rio Mendere (ou Simoente, como interpretou Lechevalier).

Apesar das evidências contrárias à localização de Tróia em Bunarbashi, a teoria de Lechevalier preponderou por quase um século. O mapa (fig. 3) que apresentou em uma comunicação em Edinburgo era bastante convincente se comparado aos existentes nas obras anteriores.

\footnotetext{
${ }^{11}$ Clarke, Edward Daniel. Travels in Various Countries, 2nd edition, Pt. II, sec. I, 1810, p. 109-12.

${ }^{12}$ Ibidem, sec. I, p. 102-5.
} 
Obviamente havia dissidentes da teoria Bunarbashi-Tróia; o major e geógrafo inglês James Rennel (1742-1830) em sua obra Observations on the Topography of the Plain of Troy... Shewing that the System of M. de Lechevalier, so long upheld, is founded on the most erroneous topography (1814), como o próprio título sugere, era contrário à teoria de Lechevalier. Em 1822, Charles Maclaren (1782-1866), em sua obra Dissertation on the Topography of the Trojan War (apud SPENCER, 1957, p. 93), em que comparava as informações topográficas extraídas da llíada com os mapas da região até então existentes, tomava partido de Hissarlik. Em 1864, um diplomata e filólogo austríaco, Johann Georg Von Hahn (1811-1869), aplicou a prova de escavar a colina de Bunarbashi, mas sua procura não resultou em qualquer confirmação. Frank Calvert (1828-1908), que vivia na Trôade e que era dono de uma parte da colina de Hissarlik, foi o primeiro, em 1865, a aplicar a prova de escavar o local. Não passou de uma pequena sondagem, mas bastou para pôr à vista peças de cerâmica e outros vestígios.

Estavam assim divididos os que acreditavam na existência de Tróia: Bunarbashi ou Hissarlik?

Entre julho e agosto de 1868, o então comerciante alemão Heinrich Schliemann realizou sua primeira viagem à Grécia em busca dos vestígios das localidades conhecidas pela obra de Homero, da qual resultou a obra intitulada Ithaka der Peloponnes und Troja, ${ }^{13}$ publicada em 1869, na qual, sob a forma de anotações de viagem, estão seus primeiros relatos sobre os monumentos e lugares como o suposto sítio do Palácio de Odisseu na ilha de Ítaca (SCHLIEMANN, 1992 [1869], p. 41-43); as fortalezas de Micenas, cidade de Agamêmnon (Ibidem, p. 8999); Argos (Ibidem, p. 100-101), Tirinto (Ibidem, 1992, p.102-104) e, obviamente, da planície troiana (Ibidem, p. 116-179).

$\mathrm{Na}$ Trôade, seu primeiro caminho foi em direção ao povoado de Bunarbashi. A suposição de que Tróia pudesse estar localizada nessa colina, Schliemann suspeitou estar errada já pela longa distância do mar,

(...) Mas à primeira vista, ela [a planície Troiana] parecia ser muito

\footnotetext{
${ }^{13}$ Existe uma tradução para o português já esgotada: Schliemann, H. Ítaca, o Peloponeso e Tróia. Tradução de Cyntia Baumgart. São Paulo, Ars Poética, 1992.
} 
extensa, estando Tróia muito longe do mar, no caso de Bunarbaschi estar realmente construída dentro dos limites da antiga cidade, como afirmam quase todos os arqueólogos que visitaram o local. (...), então cheguei à conclusão de que houve um engano sobre a localização de Tróia. (SCHLIEMANN, 1992 [1869], p. 117)

pois lhe parecia inconcebível que as tropas aquéias transpusessem tal distância várias vezes ao dia,

A distância dos altos de Bunarbaschi até o acampamento grego no cabo de Sigeum é de $14 \mathrm{~km}$, enquanto que todas as lutas e todos os avanços e recuos na llíada levam à suposição de que a distância da cidade até o acampamento grego mal deveria ter $5 \mathrm{~km}$. (lbidem, p. 136)

como descreve Homero na llíada (cantos V a VII), quando se dá a primeira batalha entre aqueus e troianos na planície entre Tróia e o acampamento dos aqueus.

Em Hissarlik, onde se situava um monte ovalado e comprido a apenas cinco quilômetros (5 km) ao sul do Helesponto e elevava-se a quarenta mestros acima da planície, Schliemann encontrou uma possível localização para seu ponto de partida e chegada, Tróia. Por causa das muralhas arruinadas que a cobriam, a parte extrema da crista deste monte era, há muito, conhecida entre os turcos pelo nome de Hissarlik, ou seja, "a fortaleza". Parte desse monte pertencia a Frank Calvert (supra), com quem Schliemann se encontrou e em cuja casa se hospedou durante essa primeira viagem. Aquele, a partir das pequenas sondagens que realizara no monte, percebeu que "o monte era formado, em sua grande parte, artificialmente, a partir das ruínas dos templos e palácios que estavam uns sobre os destroços dos outros, durante muitos séculos" (Ibidem, p. 144).

Além da plausível distância entre Hissarlik e o Helesponto, onde acamparam os aqueus, e da elevação de Hissarlik não ser natural, mas composta de ruínas, Schliemann notou que era perfeitamente possível percorrer o entorno da cidadela:

Novo ílion, com $5 \mathrm{~km}$ de perímetro, é bem marcado pelas muralhas circulares, das quais podemos ainda hoje ver as ruínas em determinados lugares. As encostas, que temos que subir e descer quando damos a volta pela cidade, são tão suaves que podemos transpô-las a passo acelerado, sem o perigo de cair. Quando Heitor e Aquiles correram três vezes em volta da cidade, percorreram $15 \mathrm{~km}$, pois, quando percorri no Japão, na companhia de cinco funcionários públicos, os $38 \mathrm{~km}$ de Yokohama a Yeddo, seis moços da estrebaria nos seguiram a pé e se rivalizaram, em rapidez, com os cavalos. (Ibidem, p. 162). 
Em 1870, tentou obter do governo turco autorização para realizar suas escavações na colina de Hissarlik; enquanto aguardava a resposta, iniciou seu trabalho no lado noroeste da colina, mas logo foi interrompido por questões de ordem burocrática, reiniciando seu trabalho no ano seguinte. Schliemann, então, baseando-se na convicção adquirida em Homero de que a Tróia de Príamo era o estabelecimento original da colina, pensou que as suas ruínas deveriam jazer no fundo do grande depósito; por isso, resolveu abrir uma trincheira cortando a montanha na direção norte-sul (fig. 4).

\begin{abstract}
Mas, a fim de, ao mesmo tempo, trazer à luz o mais antigo muro de fortificação de Pérgamo e de perceber exatamente o quanto o monte aumentou em largura por causa da acumulação de 'débris' que tem se sobreposto desde a construção desses muros, eu fiz um imenso corte na íngreme face norte do monte, numa distância de mais ou menos $20 \mathrm{~m}$ a partir do meu trabalho realizado no ano anterior. Esse corte foi feito em direção ao sul e se estendeu através da parte mais alta do platô; ele era tão largo que abrangia uma construção inteira, cujas fundações, que consistiam de pedras polidas, eu já tinha desenterrado no ano passado a uma profundidade de apenas 0,3 a 0,9 m a partir da superfície. De acordo com uma medida exata, essa construção, que parece pertencer ao século I d.C., tem em torno de $18 \mathrm{~m}$ de comprimento e $13 \mathrm{~m}$ de largura. Eu, obviamente, removi todas essas fundações, pois, estando dentro das minhas escavações, elas não tinham serventia e apenas atrapalhariam o caminho. (SCHLIEMANN, 1994 [1875], p. 61) (tradução própria). ${ }^{14}$
\end{abstract}

Tal passagem corresponde às anotações realizadas no início do primeiro ano de escavação (1871). A partir dela, pode-se perceber que, no afã de trazer à luz o estabelecimento mais antigo, Schliemann acabou por destruir grandes extensões de camadas superiores ou mais recentes. Foi durante esta primeira empreitada, no final do terceiro ano de escavação, que Schliemann encontrou, dentre muitas peças de

\footnotetext{
14 (...) But in order, at the same time, to bring to light the most ancient of the fortifying wall of the Pergamus, and to decide accurately how much the hill had increased in breadth by the débris which had been thrown down since the erection of those walls, I made an immense cutting on the face of the steep northern slope, about 66 feet from my last year's work. This cutting was made in a direction due south, and extended across the highest plateau, and was so broad that it embraced the whole building, the foundations of which, consisting of large hewn stones, I had already laid open last year to a depth of from only 1 to 3 feet below the surface. According to an exact measurement, this building, which appears to belong to the first century after Christ, is about 59 feet in length, and 43 feet in breadth. I have of course had all these foundations removed as, being within my excavation, they were of no use and would only have been in the way.

Todas as passagens citadas de Troy and Its Remains, edição inglesa de Trojanische Altertümer (1874), obra também publicada em forma de diário de campo ao fim da primeira fase de escavações no sítio de Hissarlik que compreendeu três grandes campanhas durante os anos de 1871-1873, são traduções realizadas pela própria autora e não apresentam nenhuma finalidade além de fornecer uma melhor compreensão do texto para os leitores que eventualmente tenham alguma dificuldade com a língua inglesa.
} 
cerâmica e metais variados, o "tesouro" que ele denominou Tesouro de Príamo (fig. 5), por acreditar que o muro onde o teria encontrado pertencia à Tróia de Príamo.

Esse tesouro era composto por mais de 8.700 peças em ouro, dentre as quais vasos, cálices e objetos de adorno. Schliemann encontrou esse tesouro na parte noroeste de Hissarlik onde, ironicamente, iniciou suas escavações em 1871, mas teve de interromper a atividade por causa de entraves burocráticos com pastores e pequenos proprietários que utilizavam as terras naquele lado do monte. Somente no fim de 1873, após dois anos de escavações em outras regiões do sítio sem encontrar algo que o satisfizesse, é que se voltou para o lado noroeste nos últimos dias da última campanha e desenterrou de dentro de um muro o tão aguardado 'tesouro'.

No dia 17 de junho de 1873, Schliemann escreveu em seu diário:

\begin{abstract}
Ao escavar esse muro diretamente ao lado do palácio do Rei Príamo, eu me deparei com um grande artigo de bronze da mais notável forma que chamou muito a minha atenção, sobretudo porque eu pensei ter visto ouro. (...) A fim de resguardar o ouro da ganância de meus operários e de salvá-lo para a arqueologia, (...) eu imediatamente os convoquei à sesta. (...) Enquanto os homens estavam comendo e descansando, eu retirei o tesouro utilizando uma grande faca. (...) Teria sido impossível para mim ter removido o Tesouro sem a ajuda de minha querida esposa, que me ajudou a enrolar as coisas que eu retirava em seu xale e a carregá-las. (Ibidem, p. 323-324) (tradução própria). ${ }^{15}$ (fig. 6)
\end{abstract}

Schliemann não hesitou em relacionar alguns dos objetos do Tesouro a objetos descritos ou mencionados por Homero. Um objeto ovalado de bronze com aproximadamente cinquenta centímetros $(50 \mathrm{~cm})$ de diâmetro ele associou ao a \$pij omf a I oks s a homérico (Ibidem, p. 324) (fig. 7); um escudo (a \$ pij) que teria uma espécie de protuberância em seu centro parecida com um umbigo (o mf a I oj ) (Ilíada, IV, 448; VI, 118; VIII, 62; XI, 259, 424, 457; XII, 161; XIII, 192, 264; XVI, 214; XIX, 360; e XXII, 111); um caldeirão de cobre que ele relacionou à

\footnotetext{
${ }^{15}$ In excavating this wall further and directly by the side of the palace of King Priam, I came upon a large copper article of the most remarkable form, which attracted my attention all the more as I thought I saw gold behind it. (...) In order to withdraw the treasure from the greed of my workmen, and to save it for archaeology, (...) I immediately had "paidos" called. (...) While the men were eating and resting, I cut out the Treasure with a large knife (...). It would, however, have been impossible for me to have removed the Treasure without the help of my dear wife, who stood by me ready to pack the things which I cut out in her shawl and to carry them away.
} 
I ebhj homérica (Ibidem, p. 325) (fig. 8), cujo tipo Agamêmon oferece 20 exemplares a Aquiles (Ilíada, IX, 120, 265; XIX, 244), que este também oferece como prêmio nos jogos fúnebres em honra a Pátroclo (Ilíada, XXIII, 259, 267, 485, $613,885)$ e que Príamo oferece a Aquiles como resgate em troca do corpo de Heitor (llíada, XXIV, 233); uma molheira de ouro ele relaciona ao depaj a mf ikupel I on homérico (SCHLIEMANN, 1994 [1875], p. 326-327) (fig. 9), que Hefesto deposita nas mãos de Hera (Ilíada, I, 584) e que Belerofonte oferece a Eneu (llíada, VI, 220), nessa passagem especificando que era feita de ouro (depa j x rus eon a mf ikupel I on); eram desse tipo também os recipientes utilizados pelos mensageiros de Agamêmnon, enviados à tenda de Aquiles, para libar antes de partirem de volta às naus (Ilíada, IX,656); é de um depaj a mf $i$ kupel I on que Aquiles despeja a libação a Pátroclo no canto XXIII, 219 e que oferece, no mesmo canto (vv. 656, 663, 667 e 699) ao vencido na prova de pugilato.

Ao final de sua descrição das peças do Tesouro, Schliemann fez a seguinte suposição:

É provável que algum membro da família do Rei Príamo apressadamente tenha colocado o Tesouro dentro de um baú e o tenha carregado sem ter tempo de retirar a chave; entretanto quando chegou ao muro ele fora alcançado pela mão do inimigo ou pelo fogo e foi obrigado a abandonar o baú, que foi imediatamente coberto até a altura de $1 \mathrm{~m}$ a 1,80 $m$ por cinzas e pedras do palácio real. (SCHLIEMANN, 1994 [1875], p. 333). ${ }^{16}$

Ele ainda associa ao Tesouro alguns objetos que havia encontrado alguns dias antes:

Talvez os artigos encontrados poucos dias antes em um cômodo do palácio real, ao lado do lugar onde o Tesouro foi encontrado, pertencera a essa infeliz pessoa. Esses artigos eram um elmo, um vaso de prata (...), uma elegante taça de electrum. $O$ elmo se quebrou ao ser retirado, mas eu o remendei, pois eu tinha todos os seus pedaços. As duas partes superiores, compondo a crista ( $\mathrm{a}$ / oj ), estão ilesos. (Ibidem, p. 333-334). ${ }^{17}$

\footnotetext{
${ }^{16}$ It is probable that some member of the family of King Priam hurriedly packed the Treasure into the chest and carried it off without having time to pull out the key; that when he reached the wall, however, the hand of an enemy or the fire overtook him, and he was obliged to abandon the chest, which was immediately covered to a height of from 5 to 6 feet with the red ashes and the stones of the adjoining royal palace.

${ }^{17}$ Perhaps the articles found a few days previously in a room of the royal palace, close to the place where the
} 
Schliemann retirou secretamente o "Tesouro de Príamo" da Anatólia enviando-o para Grécia, onde o manteve secretamente guardado. Por isso o governo otomano da época não mais permitiu que Schliemann escavasse em Tróia e exigiu que ele compartilhasse o tesouro. Mais tarde ele doou alguns objetos do tesouro para o Império Otomano em troca da permissão para escavar em Tróia novamente. Tais objetos estão localizados no Museu Arqueológico de Istambul. O restante foi enviado, em 1880, ao Museu Imperial de Berlim, e foi exposto no Museu do Pérgamo, em cuja posse ele se manteve até 1945, quando desapareceu. $\mathrm{Na}$ verdade, ele foi levado para a então União Soviética pelo Exército Vermelho. Durante a Guerra Fria, o governo soviético negava qualquer conhecimento sobre o destino do tesouro. Entretanto, em 1993, o tesouro foi descoberto no Museu Pushkin em Moscou (fig. 10). Iniciou-se então uma negociação para que o tesouro voltasse à Alemanha, mas em junho de 2004, diretores de museus na Rússia se pronunciaram em oposição à devolução do tesouro, justificando que era uma forma de compensação pela destruição de cidades russas pelos nazistas durante a Segunda Guerra Mundial.

O muro onde encontrara tal tesouro tão numeroso e valioso não poderia senão ser de época homérica, mas ambos não estavam no estrato mais antigo ou no estabelecimento original como Schliemann supunha estar a cidade de Príamo; eles faziam parte do que Schliemann definiu como segundo estrato. Ele, então, concluiu que o segundo estrato ou segunda cidade é o que correspondia à Tróia Homérica. Com a finalidade de encontrar mais tesouros e também trazer à luz o muro que envolvia Tróia, cuja construção Homero (llíada, VII, 452-453) atribui a Poseidon e Apolo, Schliemann destruiu o muro do nível superior.

Ao término de sua primeira série de escavações, Schliemann propôs a seguinte estratigrafia para o sítio de Tróia: o primeiro estrato compreendia seis metros $(6 \mathrm{~m})$ de altura a partir do solo original; o segundo estrato compreendia a Tróia Homérica com uma espessura de três metros $(3 \mathrm{~m})$, onde tinha encontrado 0 
Tesouro de Príamo, uma grande entrada, que identificou como a Porta Céia, e os vestígios de uma torre; o terceiro e o quarto estratos apresentavam três e dois metros ( 3 e $2 \mathrm{~m}$ ) de espessura respectivamente, e o último estrato com dois metros (2 m) corresponderia à Ílion Grega (fig. 11).

\subsection{Tirinto e Micenas}

Schliemann não conseguiu dar continuidade às escavações em Hissarlik nos anos seguintes e, em 1874, realizou algumas pequenas explorações em Micenas, sem grandes resultados; estas também foram interrompidas pelo processo judicial contra ele por parte do governo turco, que reclamava metade dos achados em Tróia. Em 1876, escavou Tirinto (hoje denominada Palaiocastron) (fig. 12) e reiniciou suas escavações em Micenas.

Tirinto era famosa na Antiguidade por ser a cidade natal de Héracles e por seus muros "ciclópicos"18 (fig. 13), aos quais Homero manifesta sua admiração pelo epíteto "t ei x i oks s a ", "bem amuralhada" (Ilíada, II, 559). O acesso à cidadela de Tirinto se dá através de uma rampa construída sobre um muro do tipo ciclópico (fig. 14); ao subir essa rampa passa-se pelo portal de entrada da cidadela (fig. 15; número 7 no plano estabelecido por Schliemann na fig. 12) e pelos vestígios de uma torre (fig. 16; número 3 no plano da fig. 12). Lá, Schliemann descreveu seus muros com suas galerias internas (fig. 17). Ainda em Tirinto, encontrou 11 exemplares de figurinhas de pequenos animais em terracota e 9 exemplares de figurinhas femininas (fig. 18).

\footnotetext{
${ }^{18}$ Sobre a denominação “ciclópico" para tais muros presentes em Tirinto e Micenas, Schliemann faz um interessante comentário, pois revela um questionamento da relação entre a mitologia e as fontes materiais de natureza muito diferente da relação que estabeleceu para o Tesouro que encontrou em Tróia: "Devo mencionar aqui que a alcunha "Muros Ciclópicos" é fundamentada sobre um erro, pois deriva da lenda de que os Ciclopes eram exímios arquitetos. (...) Há, evidentemente, nenhuma fundamentação histórica para denominar esses muros de enormes blocos "Ciclópicos" (...). Mas como a palavra é geralmente utilizada, eu não posso deixar de empregá-la." (tradução própria) "I may here mention that the name "Cyclopean walls" is founded on an error, being derived from the mythic legend that the Cyclopes were distinguished architects. (...) There is of course no historical foundation for calling walls of huge blocks "Cyclopean,"(...). But as the word has come into general use, I cannot avoid employing it.”(SCHLIEMANN, 1976 [1880], p. 3)
} 
Após essa breve passagem por Tirinto, Schliemann seguiu para Micenas (fig. 19), segundo ele, "pela mesma estrada descrita por Pausânias". ${ }^{19}$ Micenas se encontrava num estado bem diferente de Tróia; além de nunca ter sido completamente soterrada, sua localização nunca foi objeto de controvérsias. Desde o início do século XIX, ela era visitada e frequentemente pilhada por seus visitantes, alguns deles ilustres como Lord Elgin e Veli, que fora Paxá de Náuplia. Depois da libertação da Grécia da dominação dos turcos, especialmente após 1833, essas depredações deliberadas encontraram seu fim, e a partir de 1840 o sítio esteve sob a proteção da Sociedade Aqueológica Grega, então recém formada, que começou a limpar a região da Porta dos Leões.

Lá, Schliemann descreveu os muros que circundam a acrópole da cidade, também "ciclópicos" como os de Tirinto. Ele nota que esse muro é constituído por três diferentes tipos de construção:

(...) A maior parte dele é construída exatamente como os muros de Tirinto, embora não sejam tão massivos; e, como esse tipo de arquitetura é geralmente vista como a mais antiga, eu as indiquei (...) com as palavras 'Muros do primeiro período.' (SCHLIEMANN, 1976 [1880], p. 29)

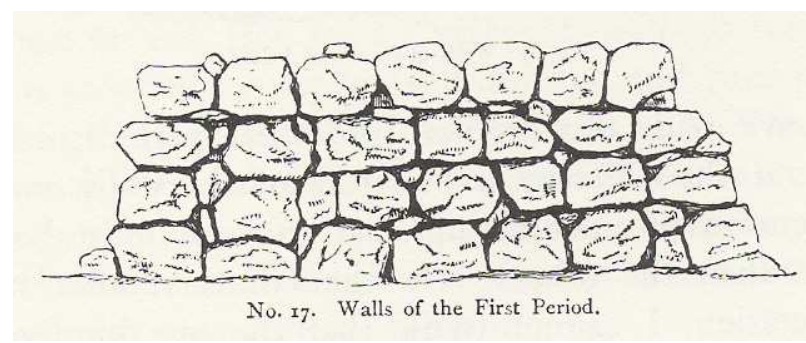

Esquema I de construção dos Muros do Primeiro Período em Micenas. Fonte da figura: Schliemann, 1976 [1880], p. 29.

(...) Uma parte grande do lado oeste do muro eu indiquei (...) como 'Muro do segundo período' porque ele consiste em pedras poligonais colocadas juntas com grande arte, de modo que, ao invés da infinita variedade de junções, ele forma um todo sólido e organizado, como se composto de uma única pedra; e esse tipo de construção, que pode ser

\footnotetext{
${ }^{19}$ (...) by the same road which Pausanias describes. (Ibidem, p. 24)

20 (...) By far the greater portion of them is built exactly like the walls of Tyrins, although not so massively; and as this kind of architecture is generally thought to be the most ancient, I have marked (...) with the words, "Walls of the first period."
} 
visto em muitos lugares na Grécia e no sul da Itália, é universalmente conhecido como geralmente de um período posterior ao muro anterior. (Ibidem, p. 29-30 $)^{21}$

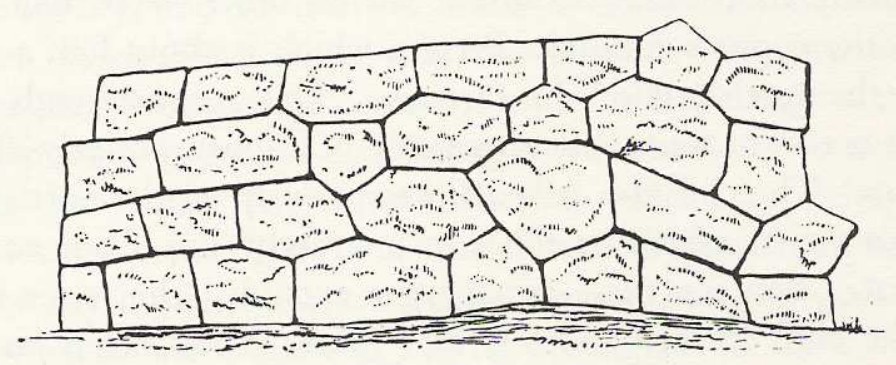

No. 18. Walls of the Second Period.

Esquema II de construção dos Muros do Segundo Período. Fonte da figura: Schliemann, 1976 [1880], p. 30.

(...) Eu indiquei (...) como 'Muros do terceiro período' a parte à direita e à esquerda do grande portão, que consiste de blocos quase quadrangulares arranjados em camadas horizontais; mas suas junções nem sempre são verticais e eles apresentam linhas mais ou menos oblíquas. (lbidem, p. 30) ${ }^{22}$

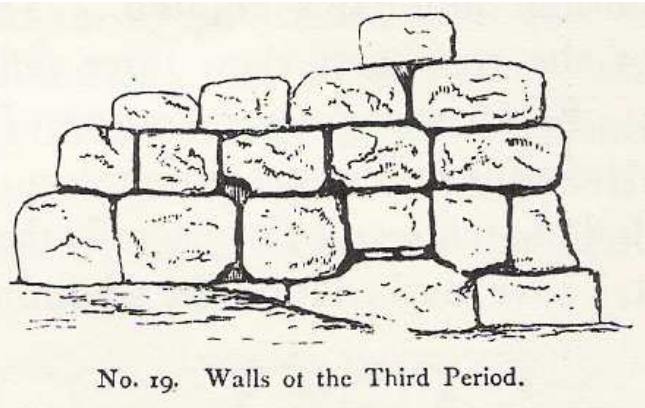

Esquema III de construção dos Muros do Terceiro Período. Fonte da figura: Schliemann, 1976 [1880], p. 30.

Eu fiz essa divisão em três períodos meramente para apontar a diferente arquitetura dos muros, sem nenhuma intenção de sustentar que

\footnotetext{
${ }^{21}$ (...) A large piece of the western wall I have marked (...) as "Walls of the second period," because it consists of polygons, fitted together with great art, so that, in spite of the infinite variety of the joints, they formed as it were one solidly united and neat wall, as if of rock; and this sort of building, which can be seen in so many places in Greece and Southern Italy, is universally acknowledged to be generally of a later period than the former.

${ }^{22}$ (...) I have marked (...) as "Walls of the third period" those walls to the right and left of the great gate, which consist of almost quadrangular blocks arranged in horizontal layers; but their joints are not always vertical and they present lines more or less oblique.
} 


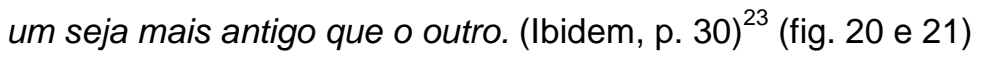

Como Tirinto, Micenas também apresentava vestígios de torres, mas não era provida de galerias internas que correm em paralelo ao muro (como demonstrado pela fig. 17), apresentando apenas uma passagem ogival que o atravessa (fig. 22). Micenas apresentava ainda um outro portão ao noroeste (fig. 23).

Dentre os cinco edifícios denominados 'tesouros' que Schliemann localizou em Micenas, então denominados fouknoi pela população local, dada a sua semelhança com fornos, o maior e mais famoso é o atribuído a Atreu. Na verdade, o Tesouro de Atreu já tinha sido visitado por outros viajantes durante o século XIX e era um monumento conhecido na região, embora sob o nome de Túmulo de Agamêmnon (fig. 24). Sua entrada é precedida por um corredor denominado drómos; o seu interior é composto por uma câmara que fora comparada por Schliemann a uma colméia (bee-hive), denominação que permanece até hoje para esse tipo de túmulo (bee-hive tomb) (fig. 25). No interior do túmulo, a partir da quarta fila de blocos, cada bloco apresentava dois furos e em muitos deles Schliemann ainda podia ver resquícios de bronze. Tendo visitado Orcômenos anteriormente, Schliemann comparou o tipo de construção e decoração do Tesouro de Atreu ao Tesouro de Mínias, apesar de o estado de preservação deste ser bastante inferior ao daquele, e concluiu que ambos deveriam ser contemporâneos.

Schliemann encontrou semelhanças entre a cerâmica proveniente de Micenas e a cerâmica encontrada num túmulo em lalysos, na ilha de Rodes, onde havia um escaravelho egípcio da época de Amenófis III, que reinou por volta de 1400 a.C. Outra importante descoberta que possibilitava relações cronológicas entre sítios diferentes foram as figurinhas femininas encontradas em Micenas do mesmo tipo das encontradas anteriormente em Tirinto (fig. 26). Iniciava-se, então, uma série de relações cronológicas que culminaria num quadro geral de datação para 0 Mediterrâneo Antigo.

Por causa de uma leitura errônea de um trecho de Pausânias, Coronel Leake, Dodwell e Ernst Curtius, que escreveram sobre o Peloponeso, pensavam que 0

\footnotetext{
${ }^{23}$ I have made this division into three periods merely to point out the different architecture of the walls, and with no intention of maintaining that one must be more ancient than the other.
} 
túmulo de Agamêmnon e seus companheiros estava dentro dos muros que abrangem tanto a Acrópole quanto a parte baixa da cidade. Schliemann, espertamente, interpretava tal passagem como se referindo apenas aos muros da Acrópole. E foi justamente no interior desses muros, nas proximidades da Porta dos Leões, que ele encontrou o Círculo Tumular A (figs. 27 e 28) que continha cinco sepulcros $^{24}$ e um total de 15 corpos cobertos com objetos de ouro e cercados de oferendas.

No interior do Sepulcro I, descobriu a intitulada Máscara que ele atribuiu a Agamêmnon (fig. 29), pois acreditava ter descoberto o túmulo do governante micênico e seus companheiros mencionado por Pausânias. Outros inúmeros objetos de ouro (fig. 30-32) encontrados são relatados na publicação Mycenae, de 1880. Essa publicação, em sua quase totalidade, descreve os achados provenientes desses túmulos que traziam à realidade a frase homérica "Micenas rica em ouro" (llíada, VI, 180; XI, 46).

Depois de Schliemann, que trabalhou em Micenas durante 15 semanas apenas, o arqueólogo grego Stamatákis assumiu a exploração do sítio, entre os anos de 1877 e 1878, através da Sociedade Arqueológica de Atenas, e descobriu o sexto túmulo no interior do Círculo Tumular A (fig. 33). Ele também continuou as escavações das casas em suas adjacências e limpou o dromos do Tesouro de Atreu que, até então, tinha uma parte bloqueada.

Durante o mesmo ano de 1878, Schliemann empreendeu novas escavações no sítio de Tróia que se seguiram pelo ano de 1879 , da qual resultaram algumas modificações sobre a cronologia do sítio, publicadas em llios: the city and the country of the Trojans, em 1880. O estrato inferior com $6 \mathrm{~m}$ de espessura foi dividido em dois estratos, o mais antigo, ou estrato da Primeira Cidade com dois metros (2 $\mathrm{m}$ ) e meio de espessura e o da Segunda Cidade (segundo estrato) com três metros e meio $(3,5 \mathrm{~m})$. O estrato homérico deixou então de corresponder ao segundo e passa ao terceiro estrato ou Terceira Cidade, cuja destruição fora causada por um grande incêndio. A Terceira Cidade passa a ser a Quarta; a Quarta, por sua vez,

\footnotetext{
${ }^{24}$ Schliemann encontraou cinco dos seis sepulcros; o sexto foi encontrado posteriormente. Na verdade, após encontrar o quinto sepulcro, Schliemann parou de escavar no interior do Círculo Tumular, pois sua fonte, Pausânias, mencionava apenas cinco túmulos.
} 
passa a ser a Quinta; e a Sexta Cidade é subdividida em dois estratos: meio metro $(0,5 \mathrm{~m})$ imediatamente acima da Quinta Cidade passa a ser identificada como uma Cidade Lídia, e a Sétima Cidade é então criada e recebe o nome de ílion Eólica (fig. 34).

Em 1883, Schliemann escavou em Tróia pela última vez, com a ajuda do arquiteto alemão Wilhelm Dörpfeld, e se recusou a fazer as correções relativas à cronologia propostas por Dörpfeld. Em 1884, publicou Troja, em que analisa os resultados dos seus dez anos de estudos em Tróia examinando sistematicamente nível por nível, cidade por cidade. E, nesse mesmo ano, voltou a Tirinto, onde revelou o palácio junto com Dörpfeld que foi o responsável por registrar essa escavação.

Enquanto Schliemann se ocupava com Tróia durante a década de 1880, Micenas foi entregue à Christos Tsountas, um arqueólogo grego que foi responsável pelo sítio durante os anos entre 1886 e 1902 (ver capítulo 2).

Em 1890, Schliemann e Dörpfeld descobriram, no extremo sul da elevação de Hissarlik, um grande edifício cuja planta era bastante semelhante à sala do trono dos palácios em Micenas e Tirinto e achava-se claramente associado ao depósito de Tróia VI, que continha grande número de fragmentos de cerâmica micênica, com as quais já tinham bastante contato a partir das escavações em Micenas e Tirinto. Planos, então, foram estabelecidos para novas escavações em 1891, mas Schliemann faleceu em 26 de dezembro de 1890. Dörpfeld, que continuou a escavar em Tróia após a morte de Schliemann, corrigiu os dados coletados nas escavações anteriores, propondo uma nova cronologia para o sítio de Tróia, na qual a cidade narrada pelos poemas homéricos corresponderia à VI Cidade e não à II ou III como acreditava Schliemann, retirando do tesouro a aura heróica que seu descobridor the havia imposto. 


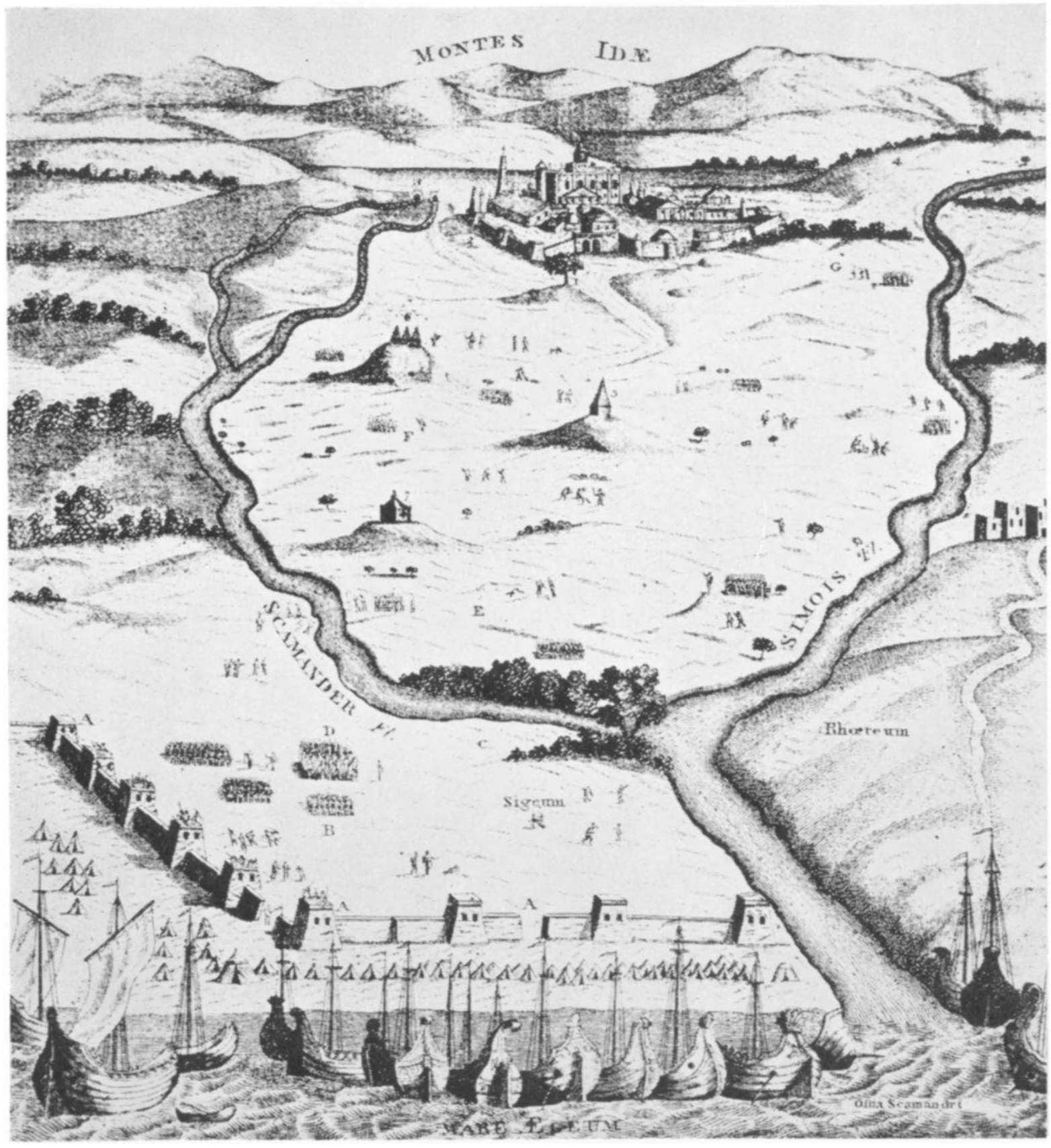

Fig. 1 Plano da Cidade de Tróia e seus arredores publicada em 1716 por Alexander Pope, em The lliad of Homer, II, 1716, p. 85. Fonte da figura: Spencer, 1957, 9a. 


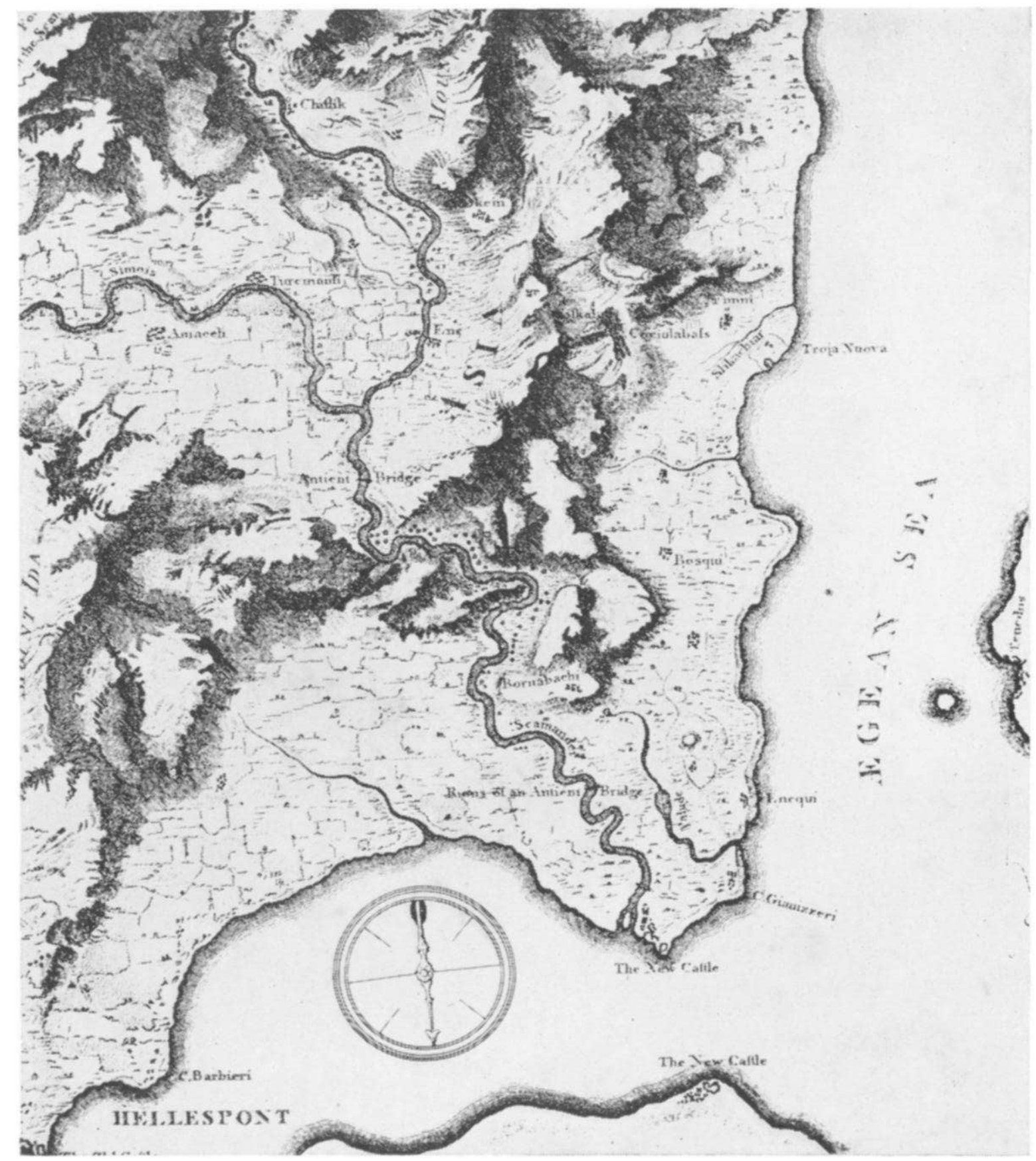

Fig. 1 Mapa da Trôade publicado em 1775 por Robert Wood, em An Essay on the Original Genius and Writings of Homer; with a comparative view of the ancient and present state of the Troad, 1775, p. 87. Fonte da figura: Spencer, 1957, 9b. 
ํํㅁ

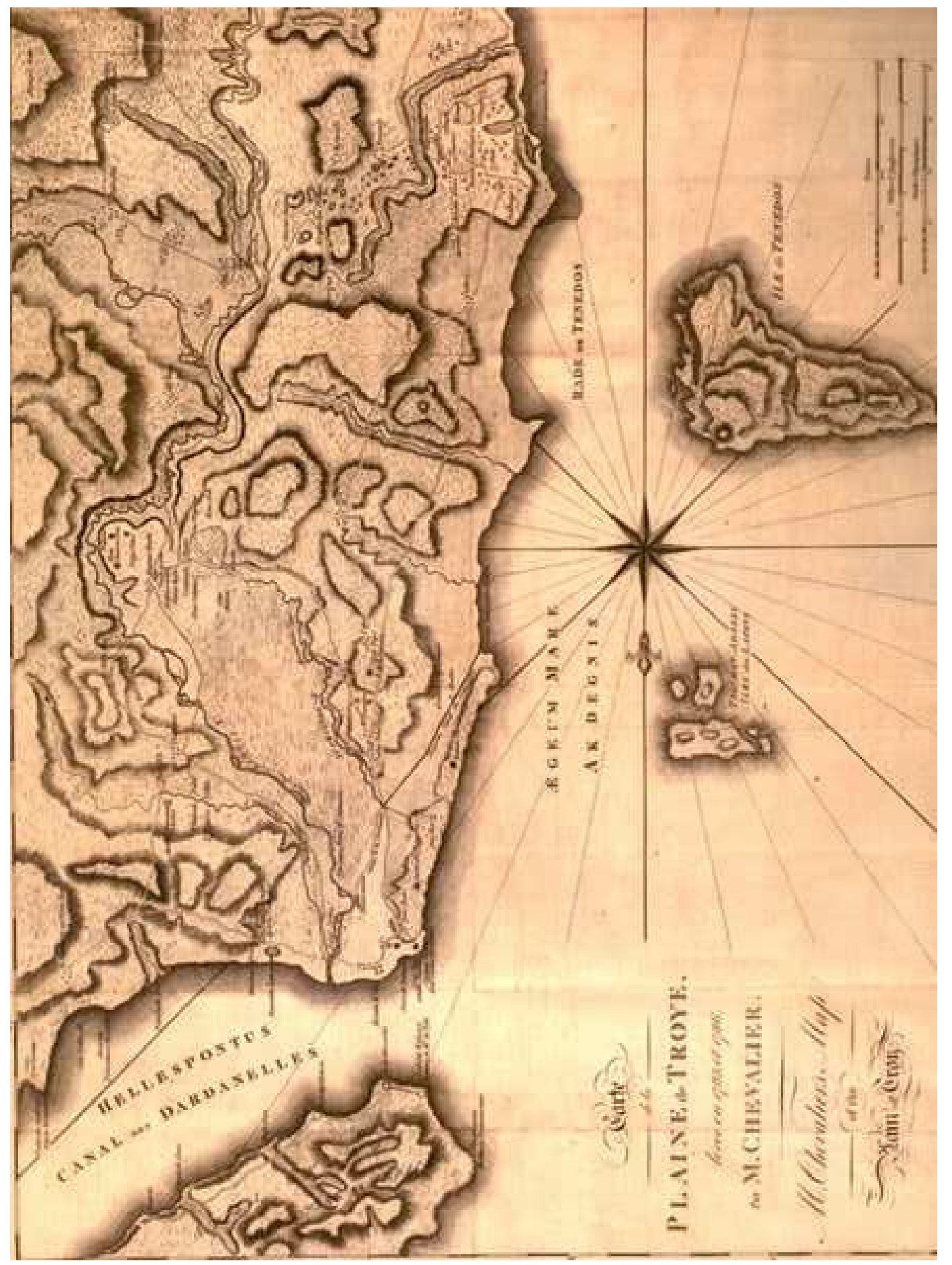

के ब

용

$\leqslant$

ริ

కิำ

岺

प응

공믄

o

ণิ 임

ते 긍

\&

क

co

옹 엄

政

ऽิ

5 के

है )

co

ம

드ㄴㅡㅗ

등

흐

む

U

$\sum$ 을

휴

응 윽

응 긍

흐임

증 끈

은 츤

응

응

을

증

증

都

圁

m 흔

원 


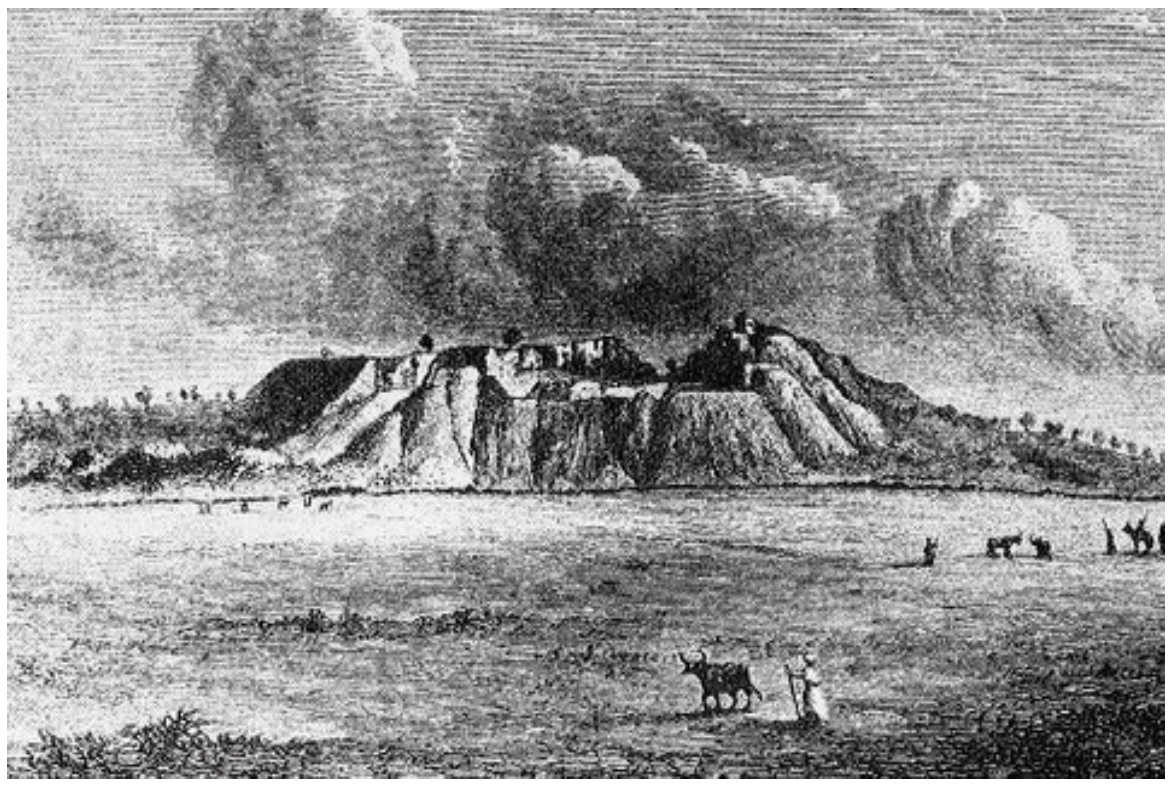

Fig. 4: Vista norte da trincheira escavada por Schliemann em Hissarlik (Tróia), em 1873. Fonte da figura: Schliemann, 1994 [1875], p. 64.

Fig. 5 Visão geral do Tesouro de Príamo, quando de sua descoberta, em 1873. Fonte da figura:

$<$ http://www.detecting.org.uk/images/Priams2 .jpg >. Último acesso em 22/05/2007.
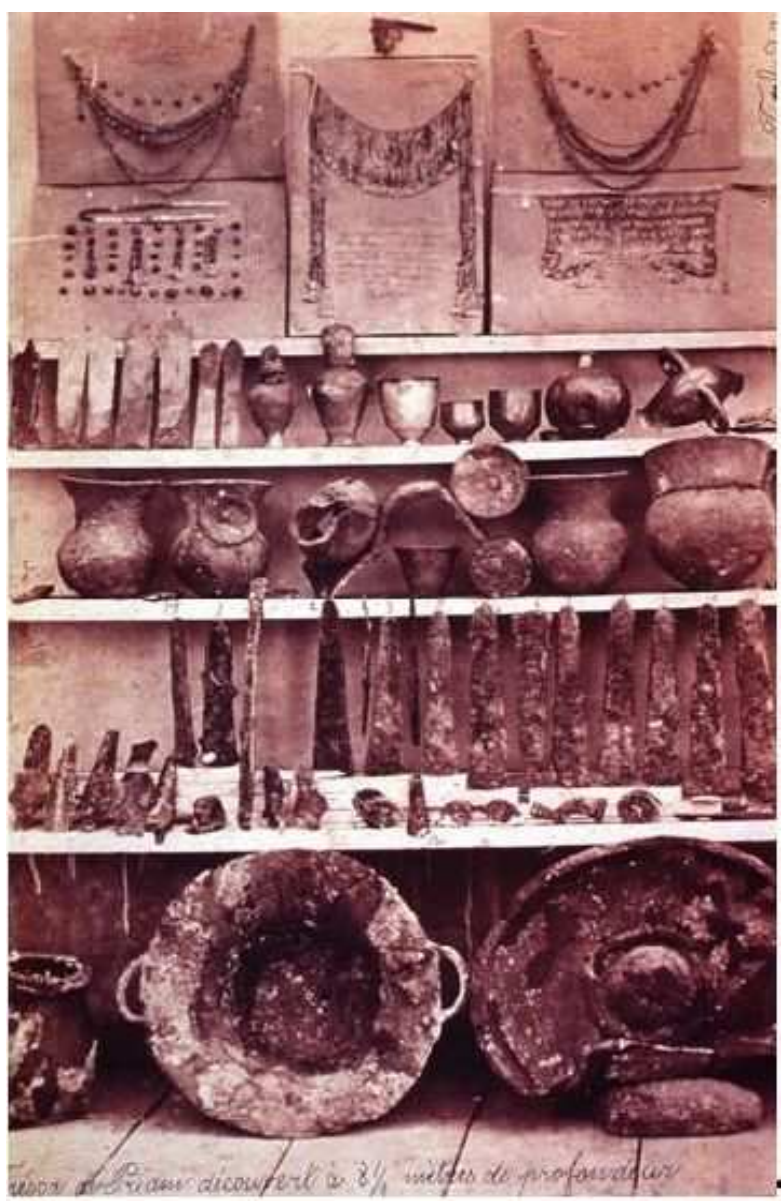


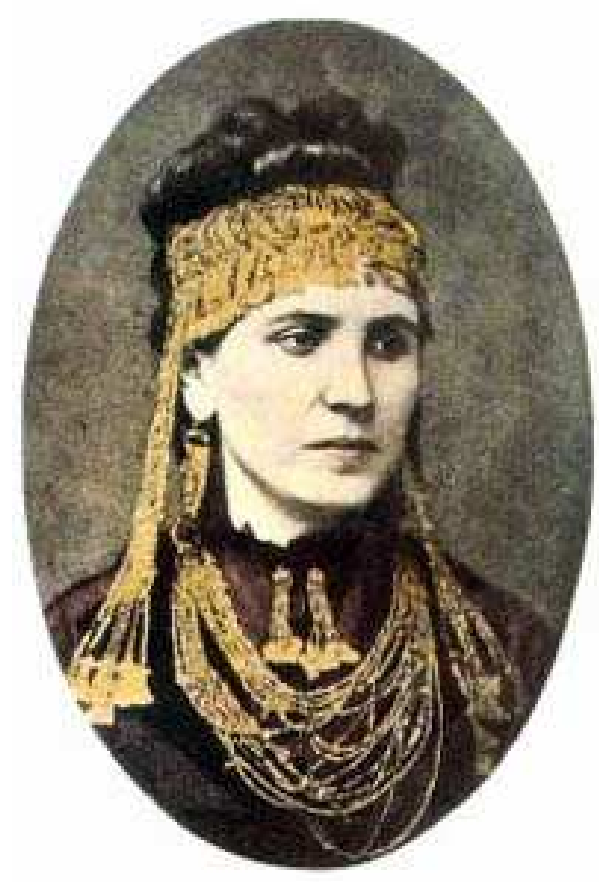

Fig. 6 Sophia, esposa de Schliemann, vestindo as jóias do Tesouro de Príamo. Fonte da figura: $<$ http://home.att.net/ a.a.major/sophie.jpg >. Último acesso em 11/11/2007.

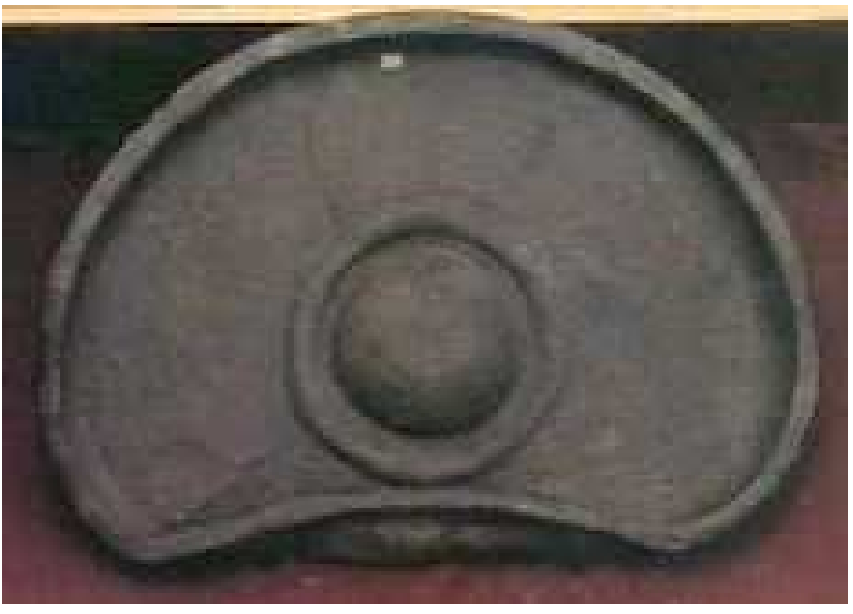

Fig. 7 Objeto ovalado encontrado por Schliemann que ele relacionou ao a $\$$ pij o mf a I oks s a homérico. Museu Pushkin, Russia. Inventário $P$ 359 A 5817. Fonte da figura:

$<$ www.yorku.ca/.../+3130\%202006/3130jan262006.htm> (detalhe). Último acesso em $26 / 01 / 2006$.

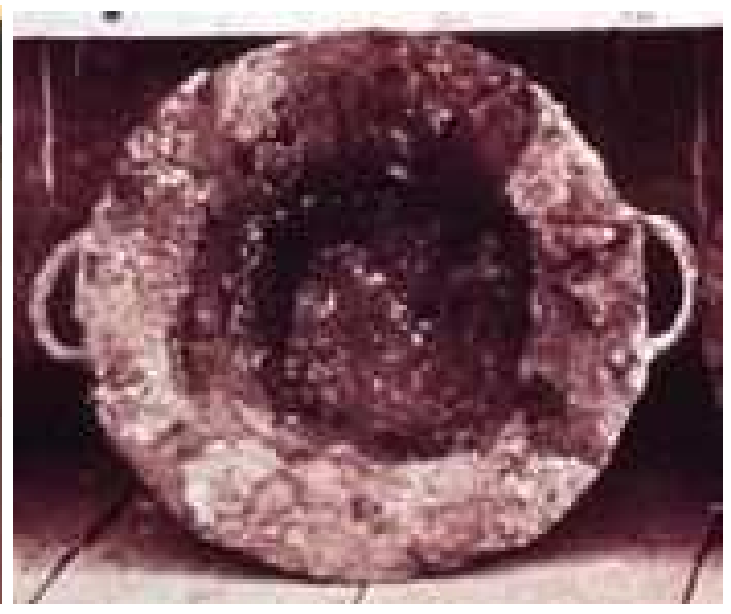

Fig. 8 Caldeirão de cobre encontrado por Schliemann. Diâmetro: $42 \mathrm{~cm}$. Altura: 14 $\mathrm{cm}$. Fonte da figura:

$<$ http://en.wikipedia.org/wiki/lmage:Priam $\% 27 s$ _treasure.JPG> (detalhe). Último acesso em 26/01/2006. 


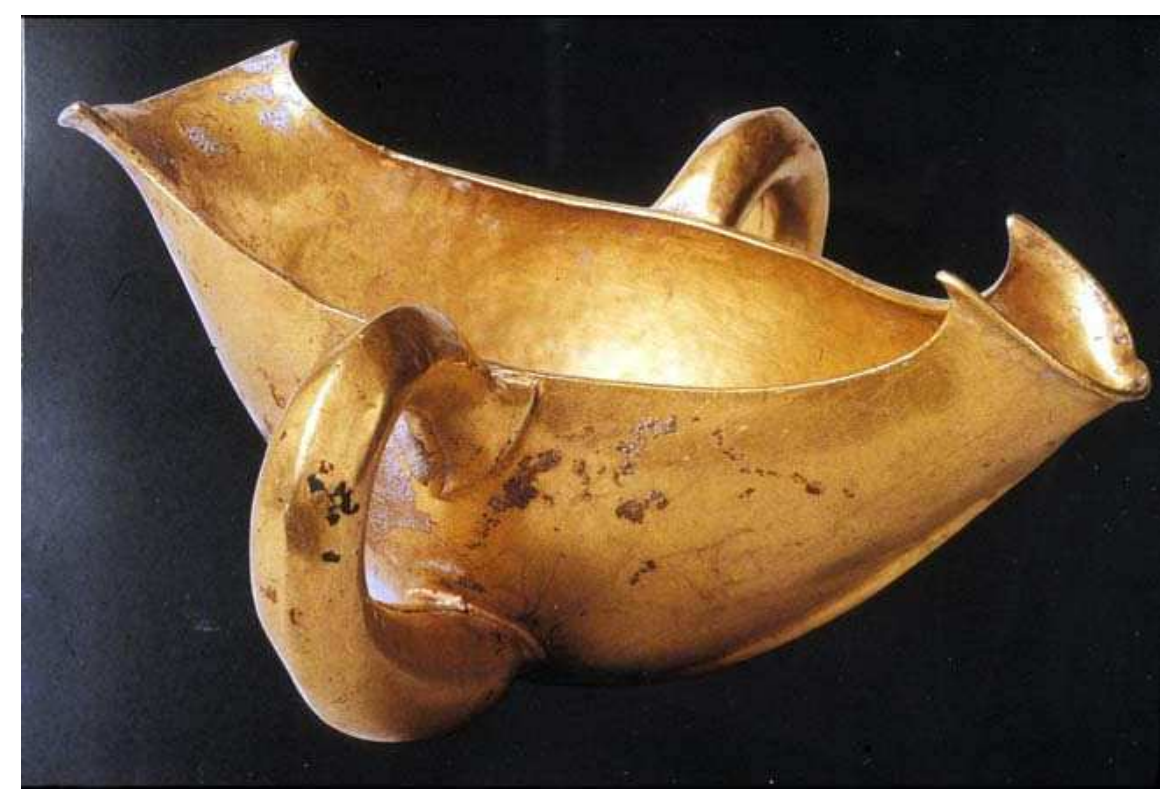

Fig. 9 Molheira de ouro encontrada por Schliemann. Peso: 600 g. Fonte da figura: http://www.utexas.edu/courses/classicalarch/images2/troy2goldsauce.jpg. Último acesso em 31/05/2007.

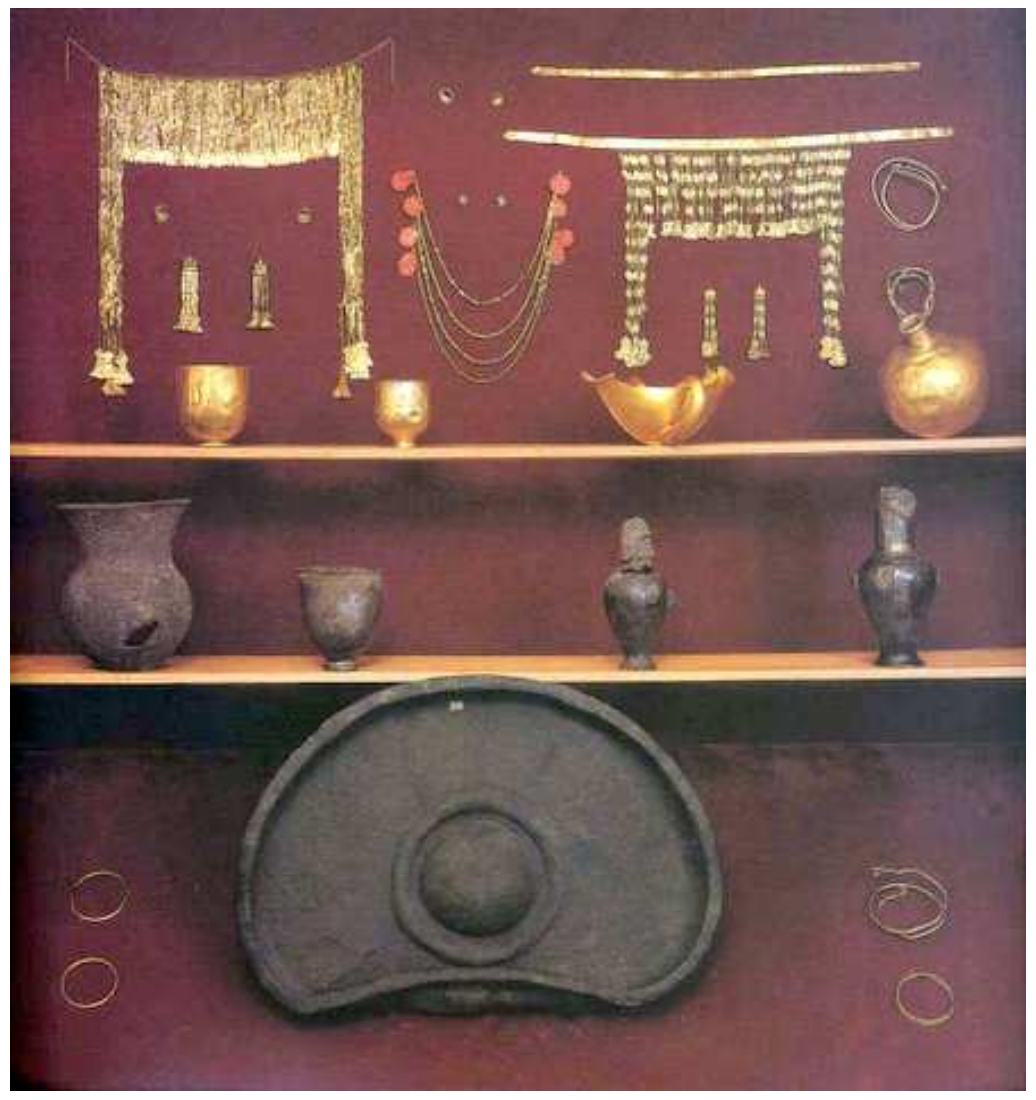

Fig. 10 Visão geral da exposição do Tesouro de Príamo no Museu Pushkin, Rússia. Fonte da figura: http://www.utexas.edu/courses/classicalarch/images2/Troy2gold2.jpg>. Último acesso em 29/05/2007. 


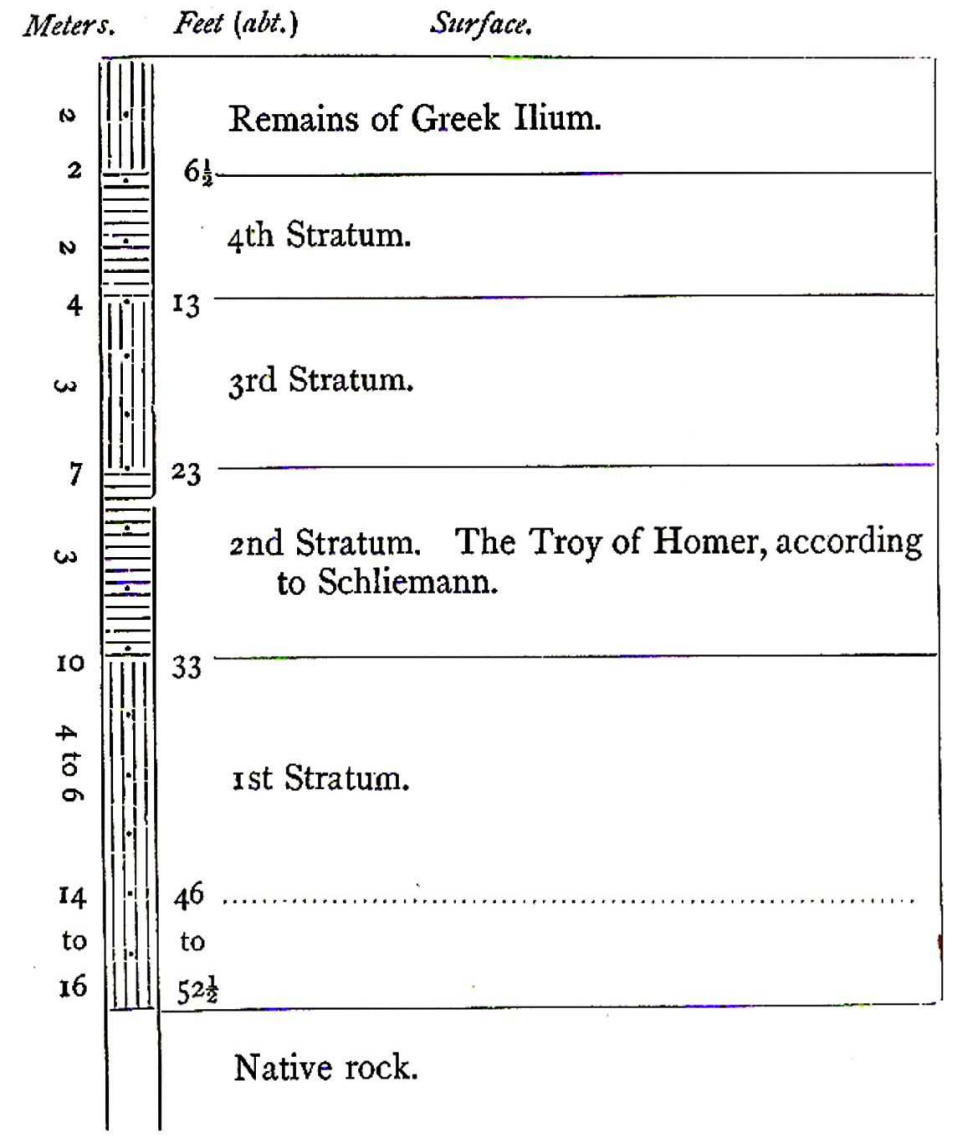

Fig. 11 Diagrama da sucessão de estratos em Hissarlik, estabelecido por Schliemann no final da primeira fase de escavações durante os anos de 1871-73. Fonte da figura: Schliemann, 1994 [1875], p. 10. 


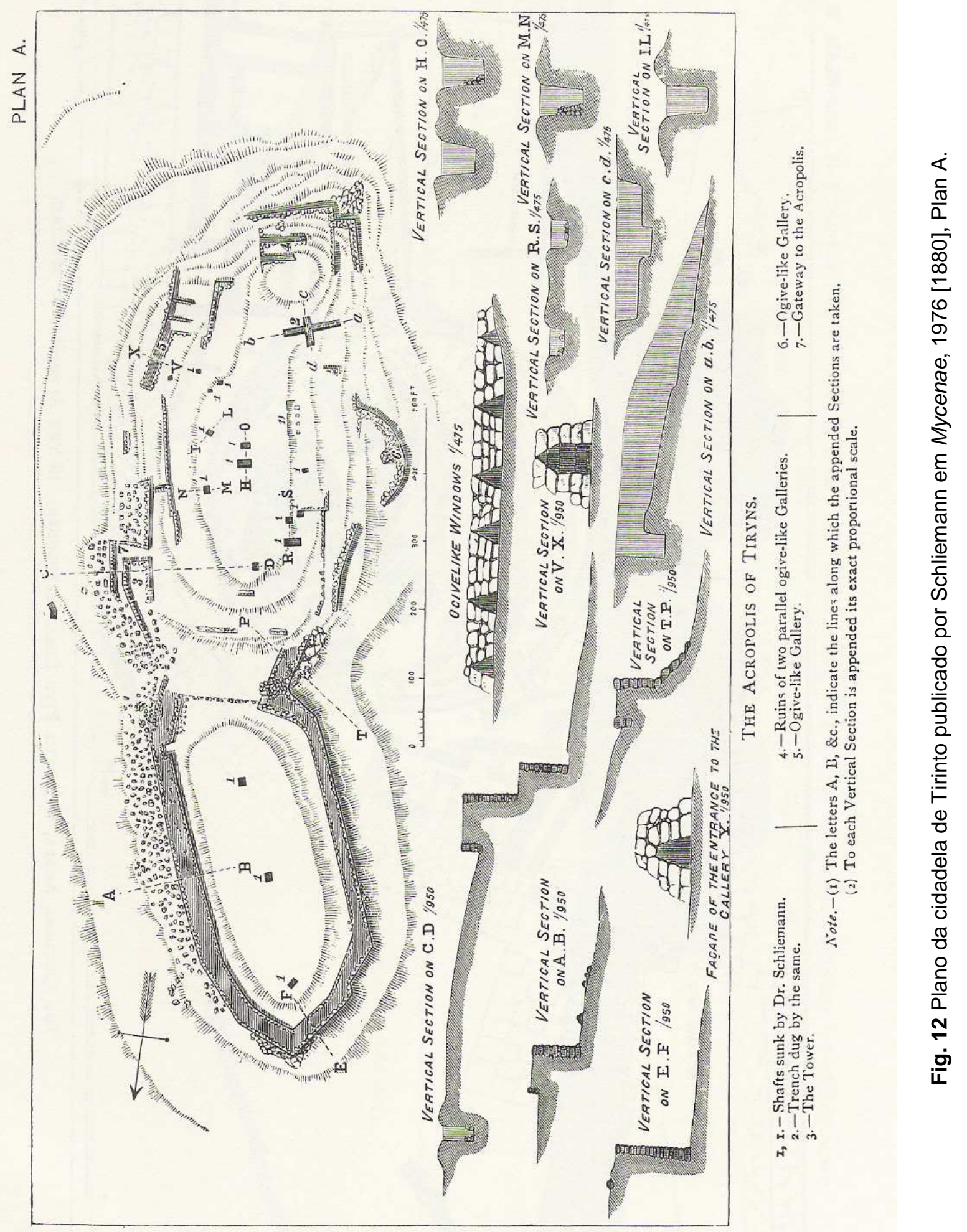




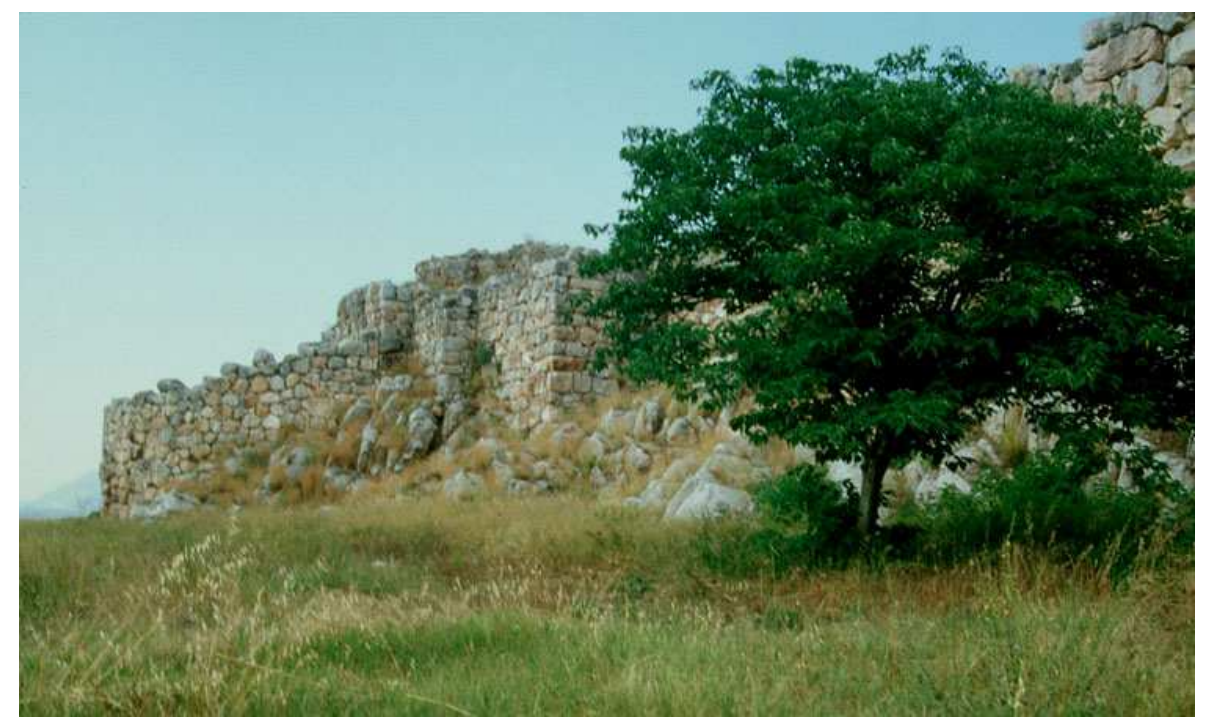

Fig. 13 Muro 'ciclópico' do lado sul de Tirinto. Fonte da figura:

$<$ http://www.odysseyadventures.ca/articles/mycenae/tiryns casemates-south.htm>. Último acesso em $11 / 11 / 2007$.

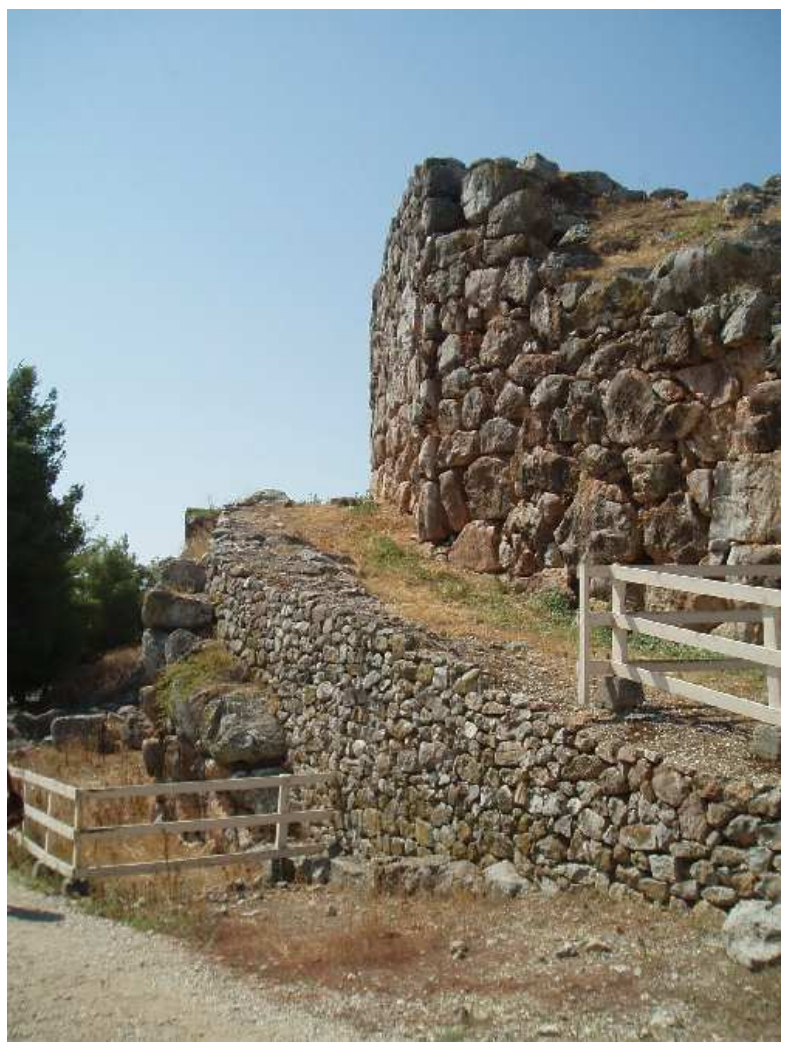

Fig. 14 Esquerda: Rampa de acesso a Tirinto construída sobre muros ciclópicos. Fonte da figura:

<http://www.megalithic.co.uk/modules.php?op $=$ modload\&name $=$ a312\&file $=$ index\&do $=$ showpi c\&pid=23466 > . Último acesso em 24/10/2007.

Fig. 15 Abaixo: Portal de entrada de Tirinto. Fonte da figura:

$<$ http://www.megalithic.co.uk/modules.php?op= modload\&name $=$ a312\&file $=$ index\&do=showpic \&pid=23465 > . Último acesso em 24/10/2007.

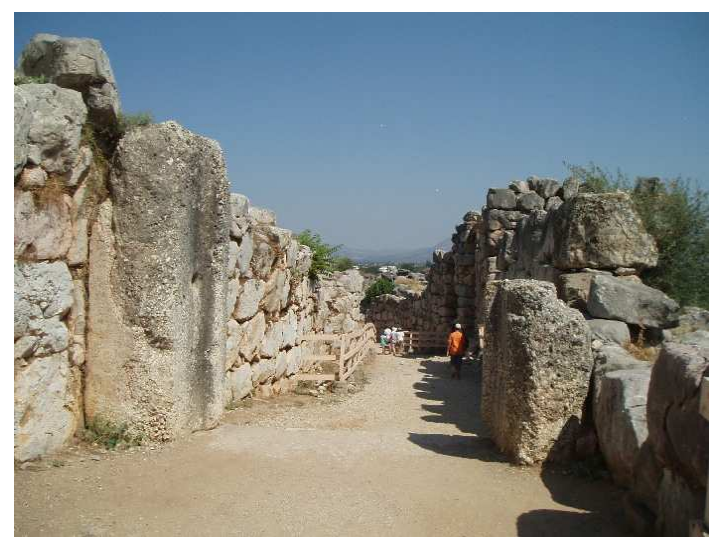


Fig. 17 Direita: Galerias internas de Tirinto. Fonte da figura:

$<$ http://www.derbiogrieche.de/drepanon/gan zalt.html>. Último acesso em 24/10/2007.

Fig. 16 Abaixo: Vestígios de torre à direita do portal de entrada de Tirinto. Fonte da figura:

<http://www.megalithic.co.uk/modules.php?op= modload\&name $=$ a312\&file $=$ index\&do=showpic pid=23464 > . Último acesso em 24/10/2007.
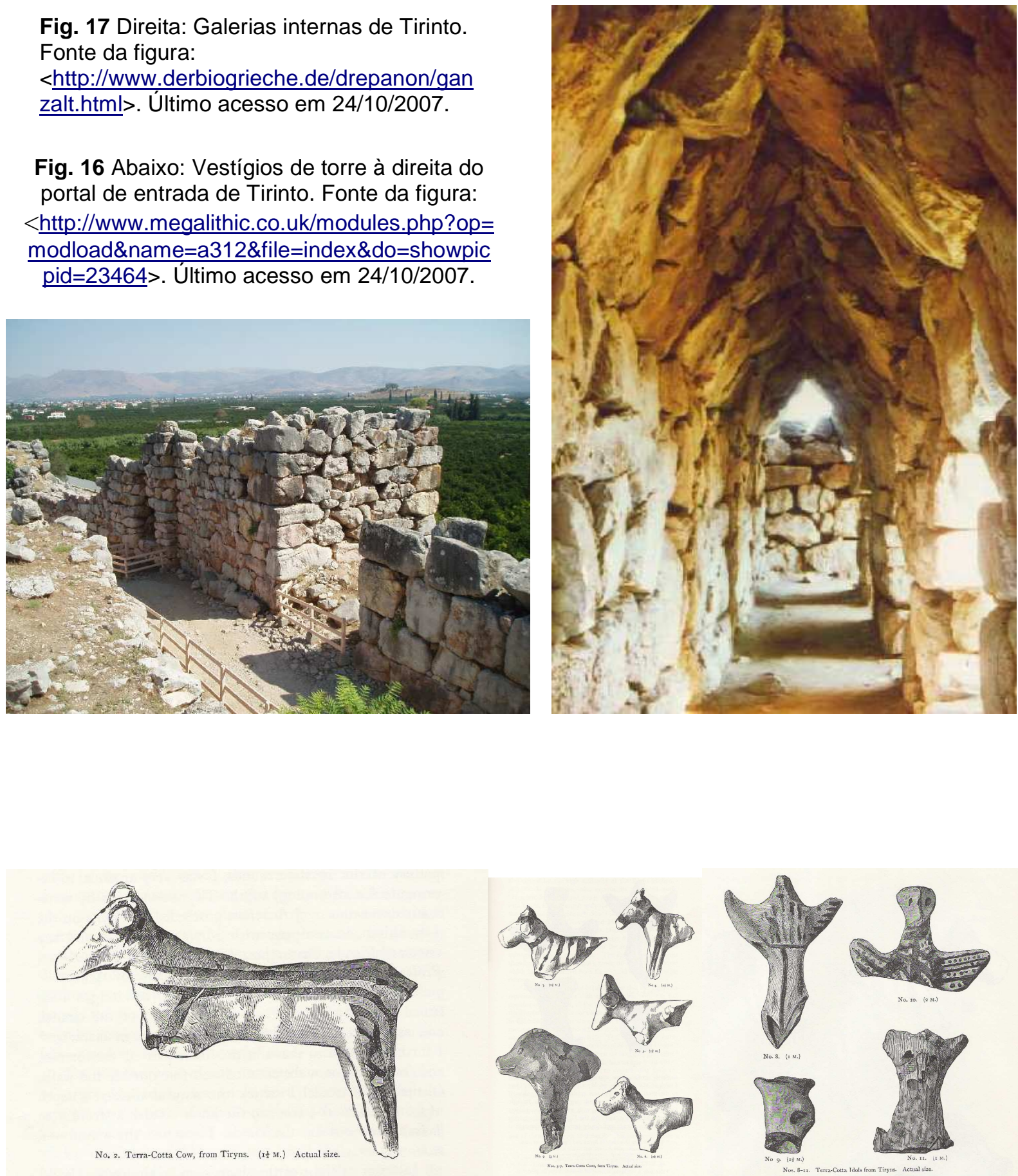

Fig. 18 Algumas das figurinhas de animais e figurinhas femininas em terracota encontradas em Tirinto por Schliemann. Fonte da figura: Schliemann, 1976 [1880], p. 10-12. 


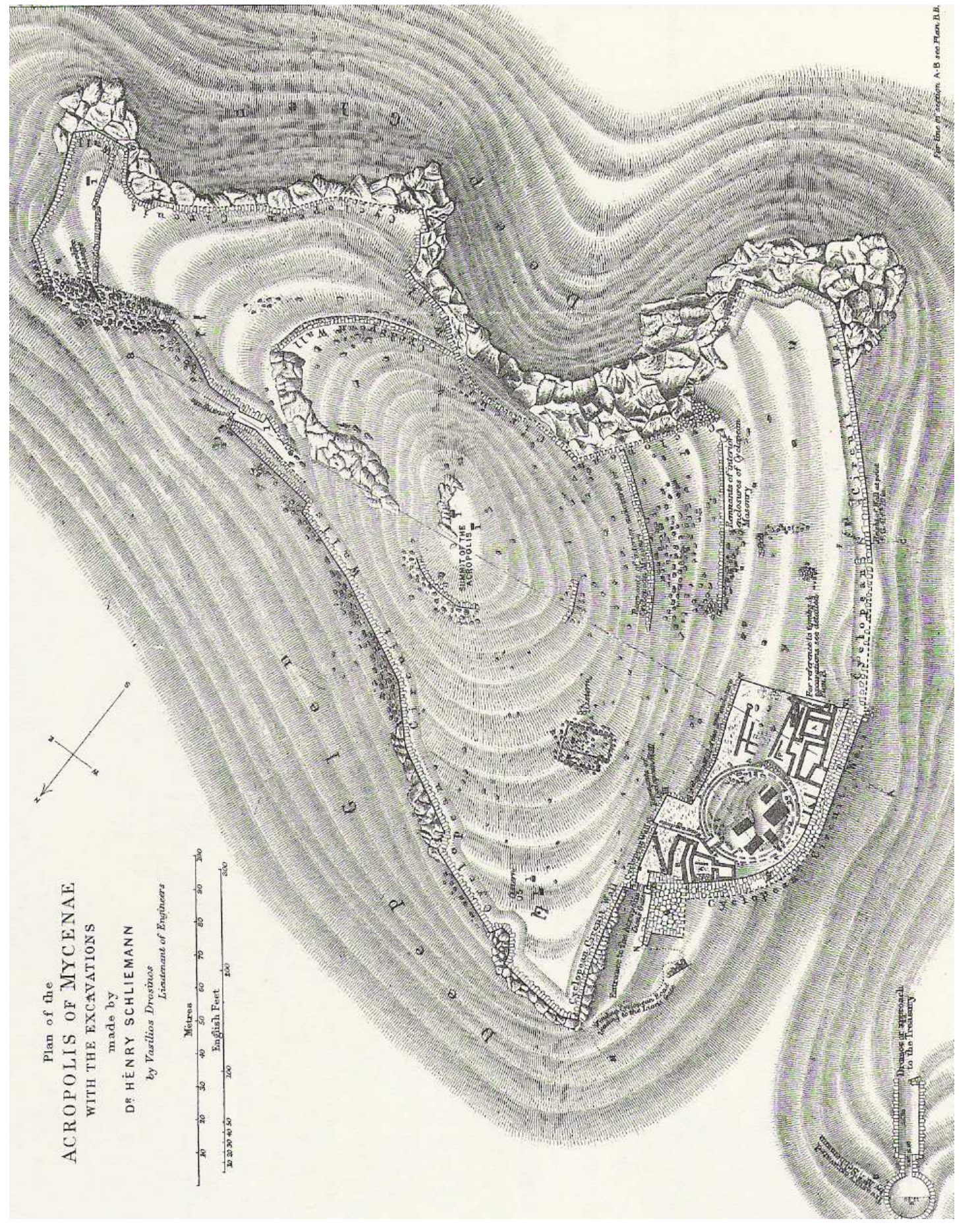

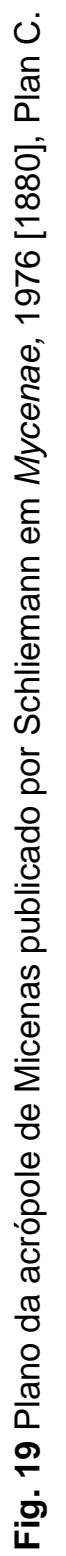




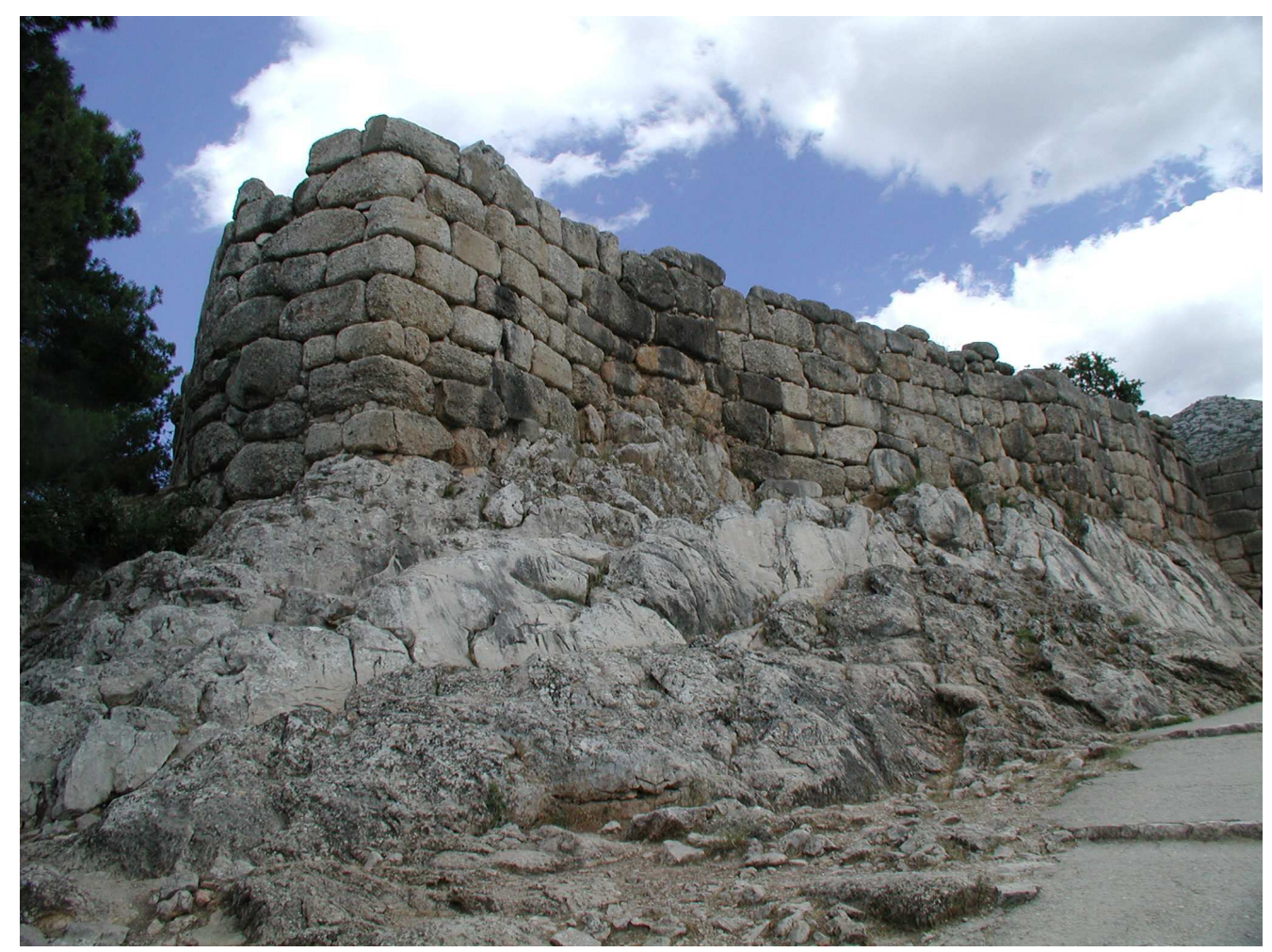

Fig. 20 Bastião à direita da Porta dos Leões, Micenas, construído sob o esquema correspondente ao 'terceiro período'. Fonte da figura:

$<$ http://wms.erudition.net/images/greece/mycenae/cyclopean wall1.jpg > Último acesso em $11 / 11 / 2007$.

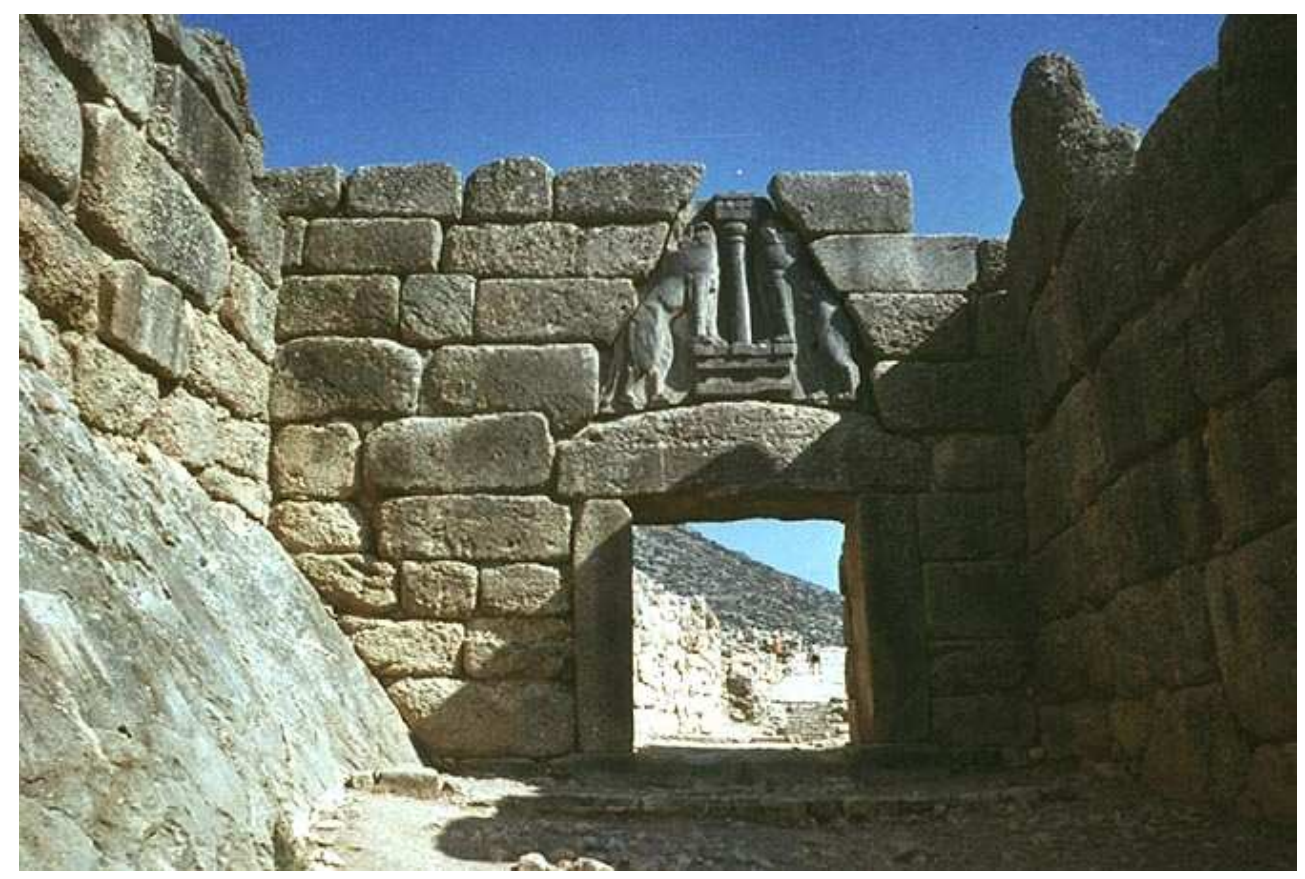

Fig. 21 Porta dos Leões, Micenas, também construída na técnica do 'terceiro período'. Fonte da figura:

<http://employees.oneonta.edu/farberas/arth/Images/ARTH209images/Mycenaean/lions gate.jpg>. Último acesso em 24/10/07. 


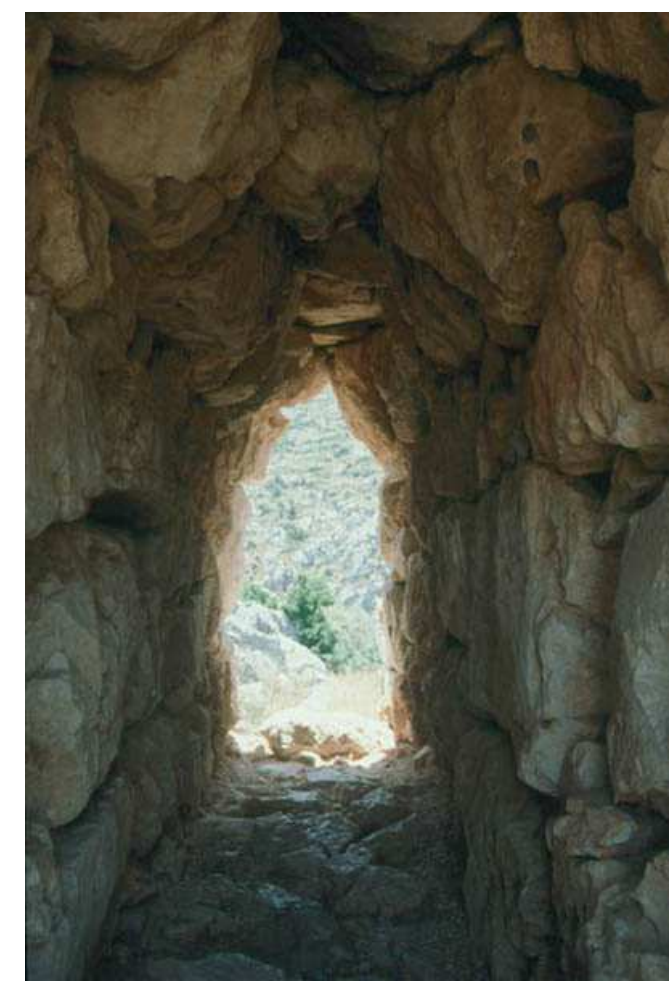

Fig. 22 Postigo ogival que cruza o interior do muro de Micenas. Fonte da figura: $<$ http://www.odysseyadventures.ca/articles/ mycenae/mycenae sallyport.htm>. Último acesso em 26/06/2008.

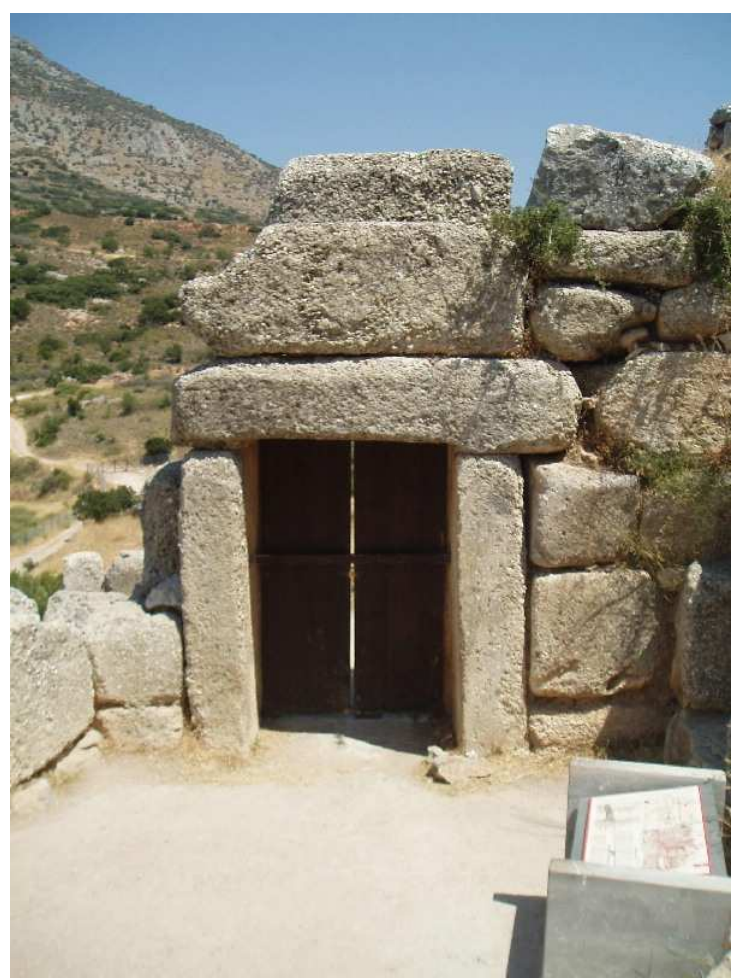

Fig. 23 Portão norte de Micenas. Fonte da figura:

$<$ http://www.megalithic.co.uk/modules.php?o $\mathrm{p}=$ modload \&name $=\mathrm{a} 312 \&$ file $=$ inde $\&$ do $=$ sho wpic\&pid $=23254>$. Último acesso em $24 / 10 / 07$.

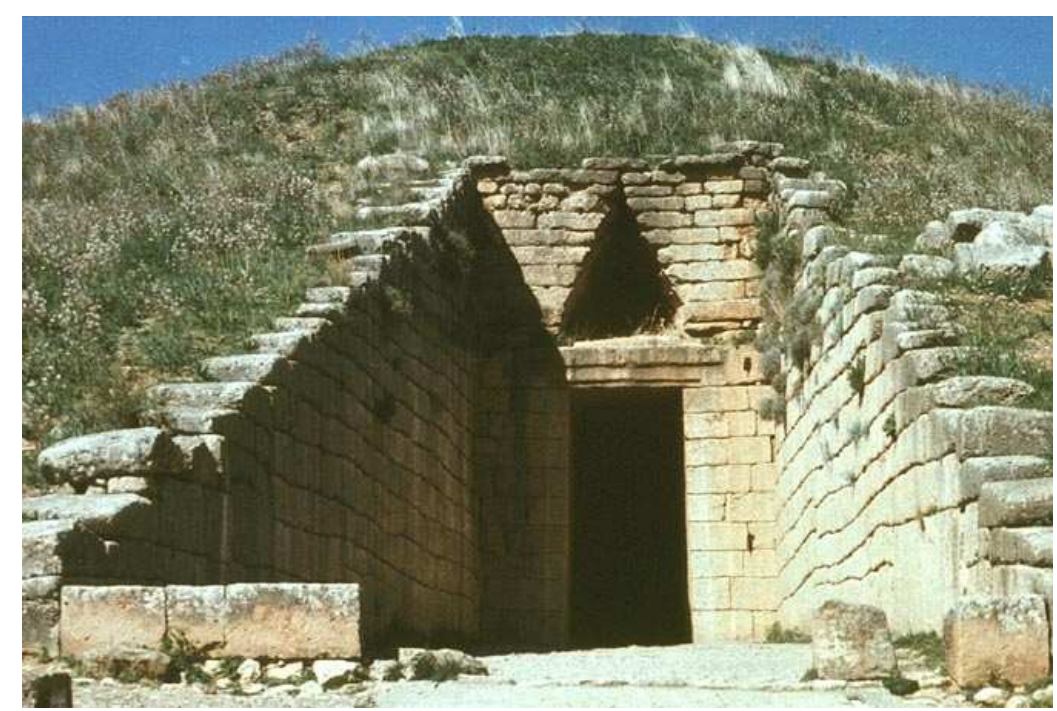

Fig. 24 Dromos e porta de acesso ao Tesouro de Atreu, Micenas. Fonte da figura: $<$ http://employees.oneonta.edu/farberas/arth/Images/ARTH209images/Mycenaean/treas atreus entr. ipg >. Último acesso em 24/10/07. 


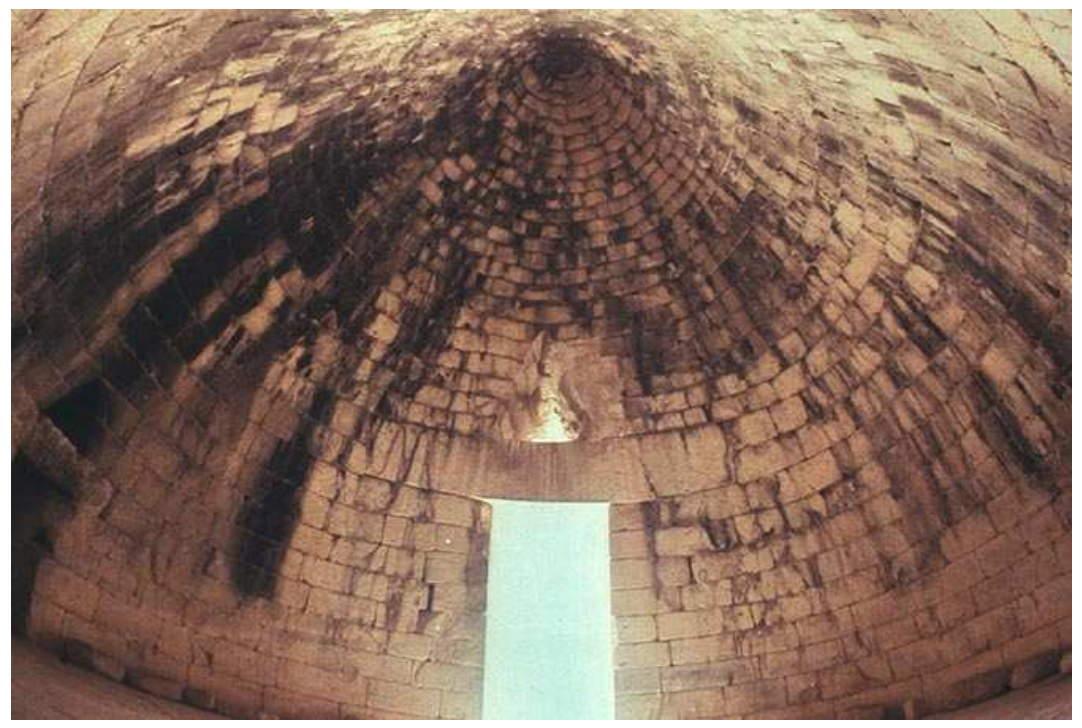

Fig. 25 Interior do Tesouro de Atreu, Micenas. Fonte da figura:

< http://employees.oneonta.edu/farberas/arth/Images/ARTH209images/Mycenaean/treas atreus int.jp g>. Último acesso em 25/10/2007.

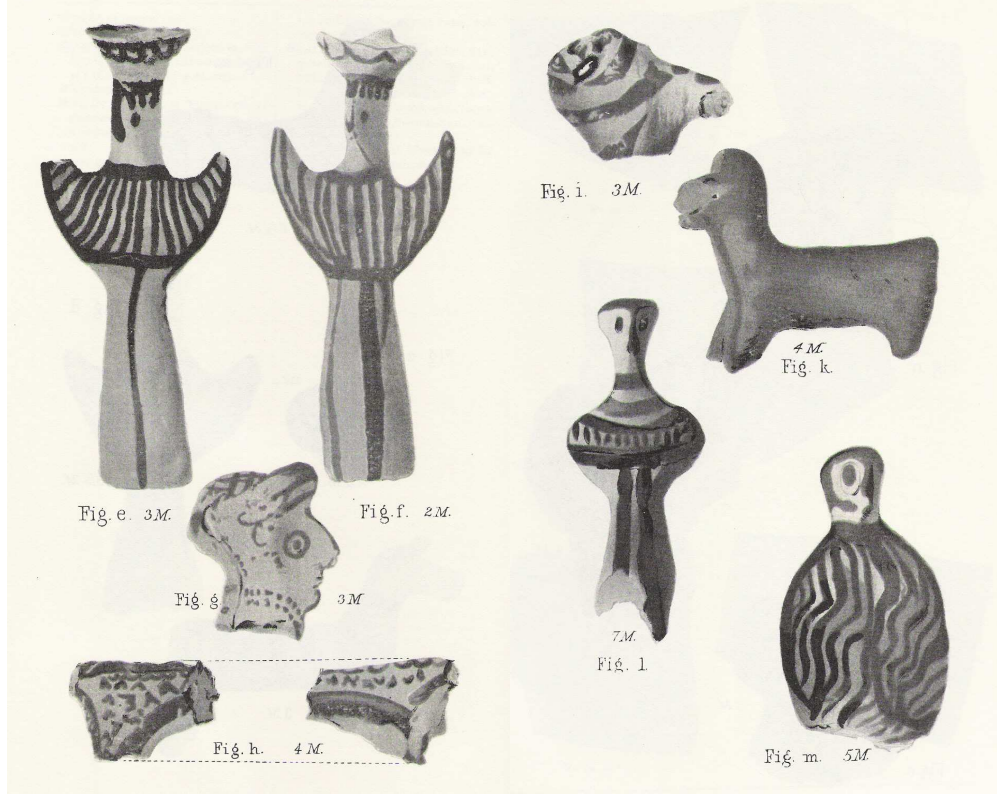

Fig. 26 Figurinhas em terracota encontradas em Micenas por Schliemann semelhantes às encontradas em Tirinto. Fonte da figura: Schliemann, 1976 [1880], Plate B e Plate C. 


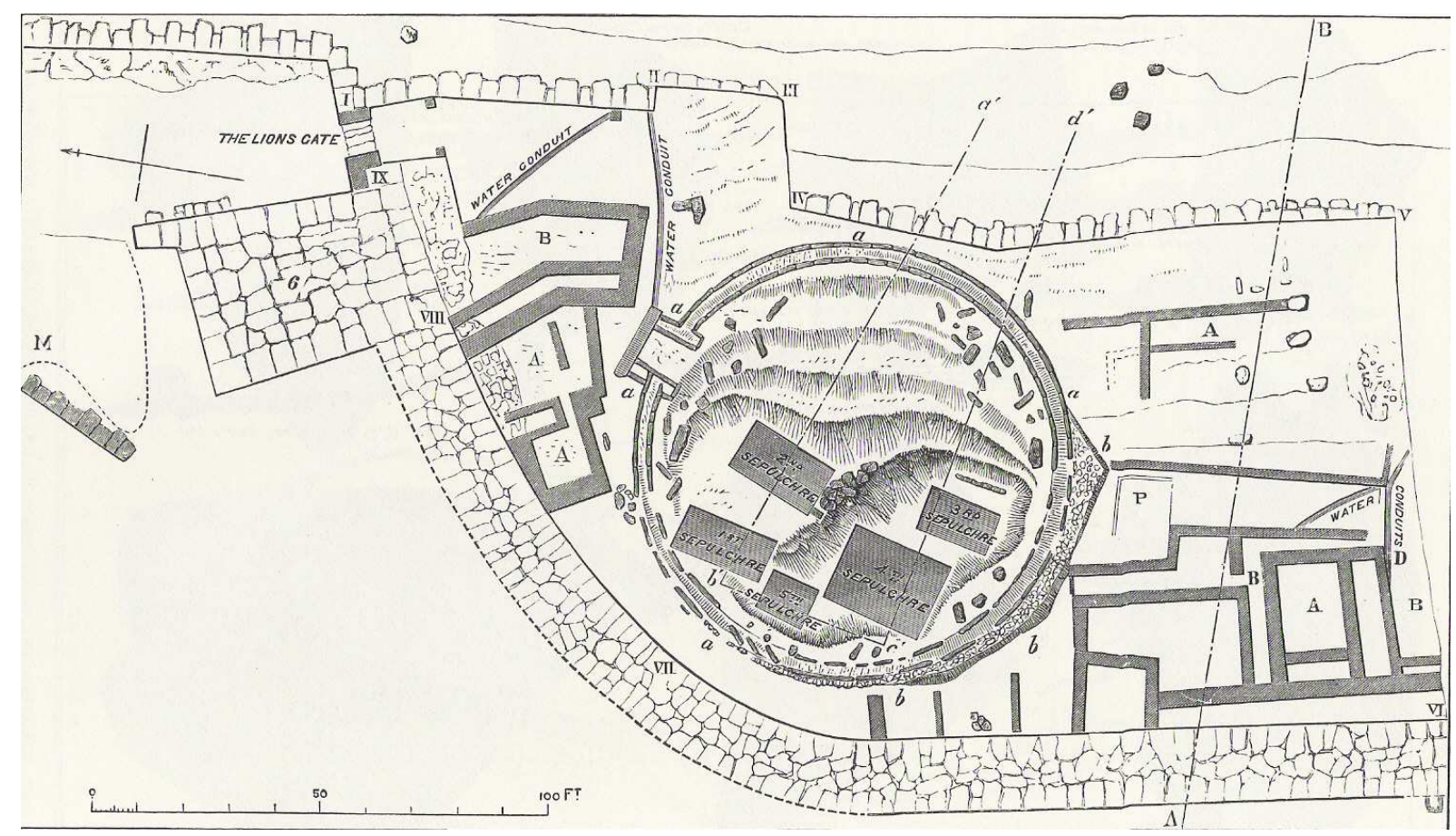

Fig. 27 Plano do Círculo Tumular Circular A e seus arredores, em Micenas, publicado por Schliemann. Fonte da figura: Schliemann, 1976 [1880], Plan B.

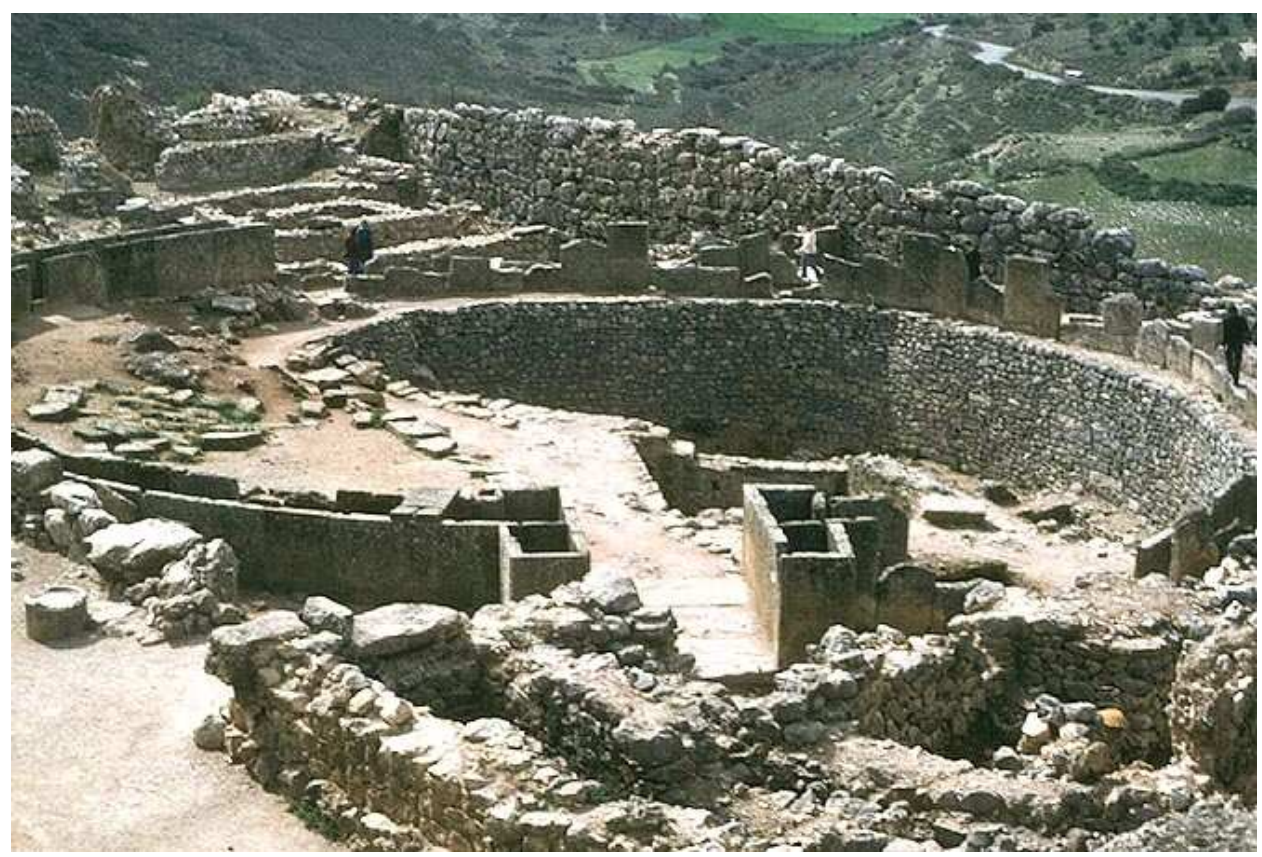

Fig. 28 Círculo Tumular A visto a partir da Porta dos Leões, Micenas. Fonte da figura: $<$ http://employees.oneonta.edu/farberas/arth/Images/ARTH209images/Mycenaean/roy grav circ a.jp g>. Último acesso em 25/10/07. 


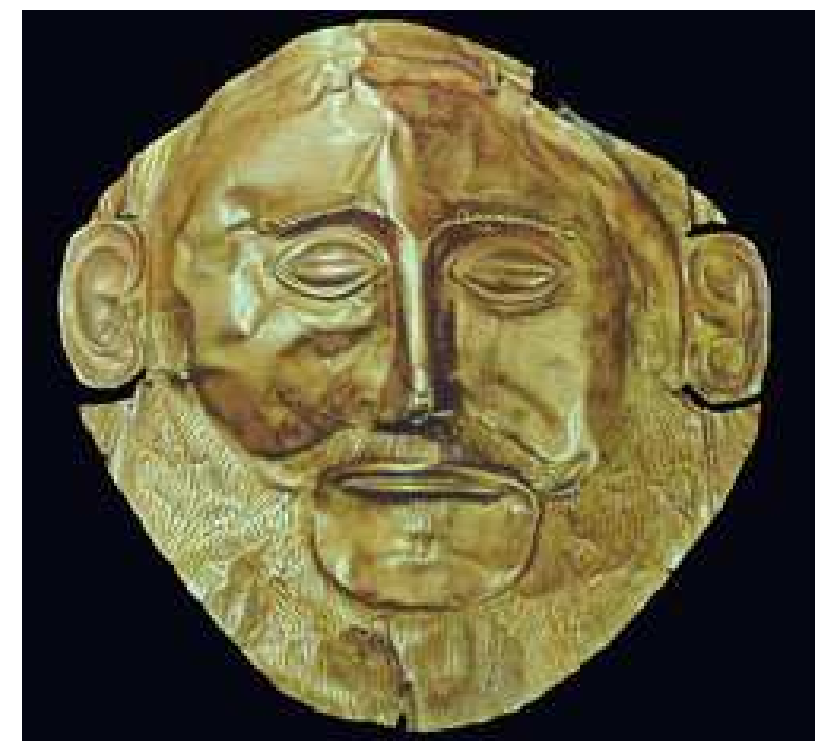

Fig. 29 Esquerda: "Máscara de Agamêmnon" encontrada no interior do Sepulcro I do Círculo Tumular A, em Micenas.. Fonte da figura:

$<$ http://www.odysseyadventures.ca/articl es/mycenae/article mycenae.htm $>$.

Último acesso em 11/11/07.

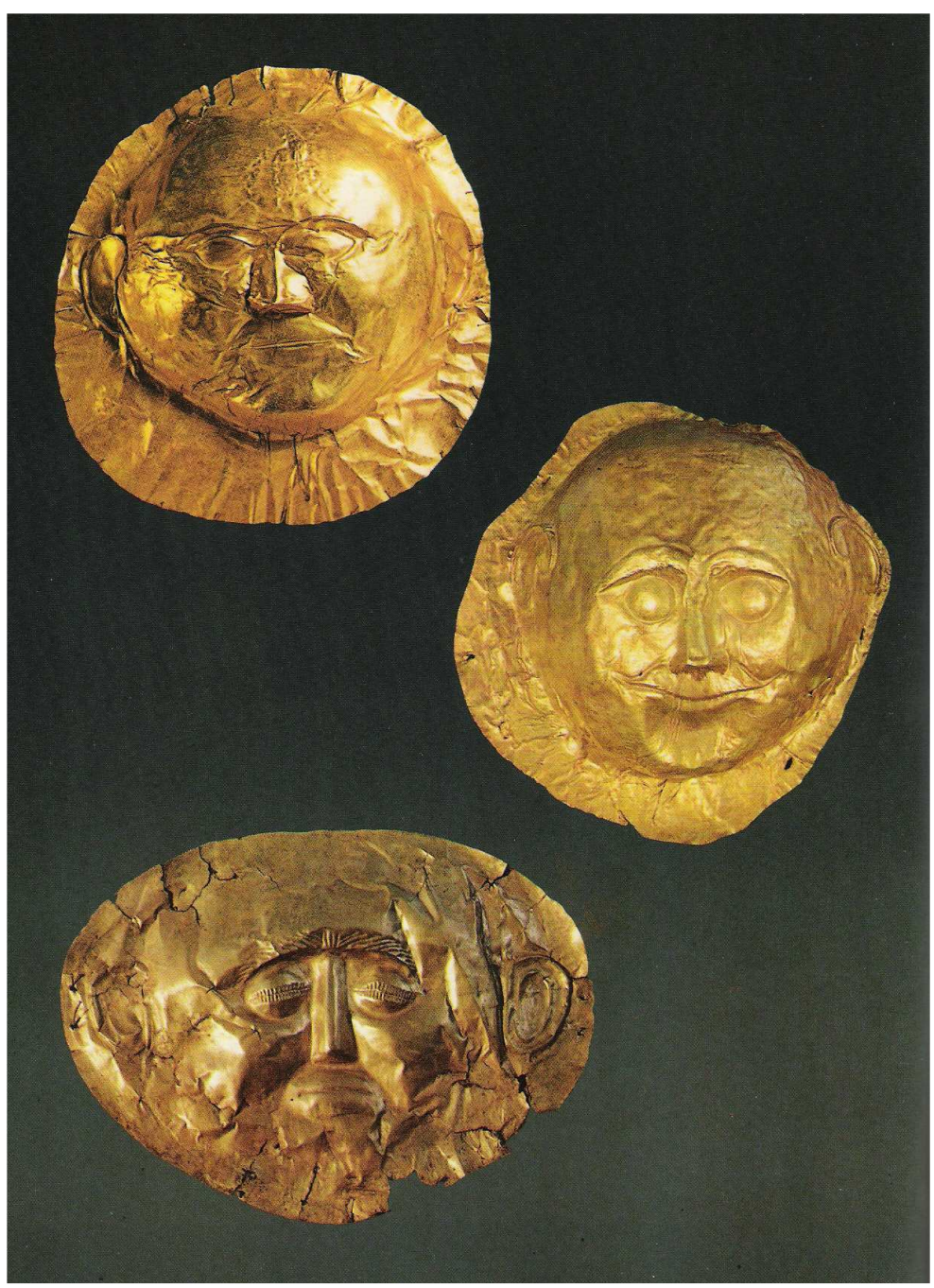

Fig. 30 Direita: Máscaras mortuárias em ouro encontradas no interior do Sepulcro IV do Círculo Tumular A em Micenas. Fonte da figura: Mylonas, 1985 , p. 36. 

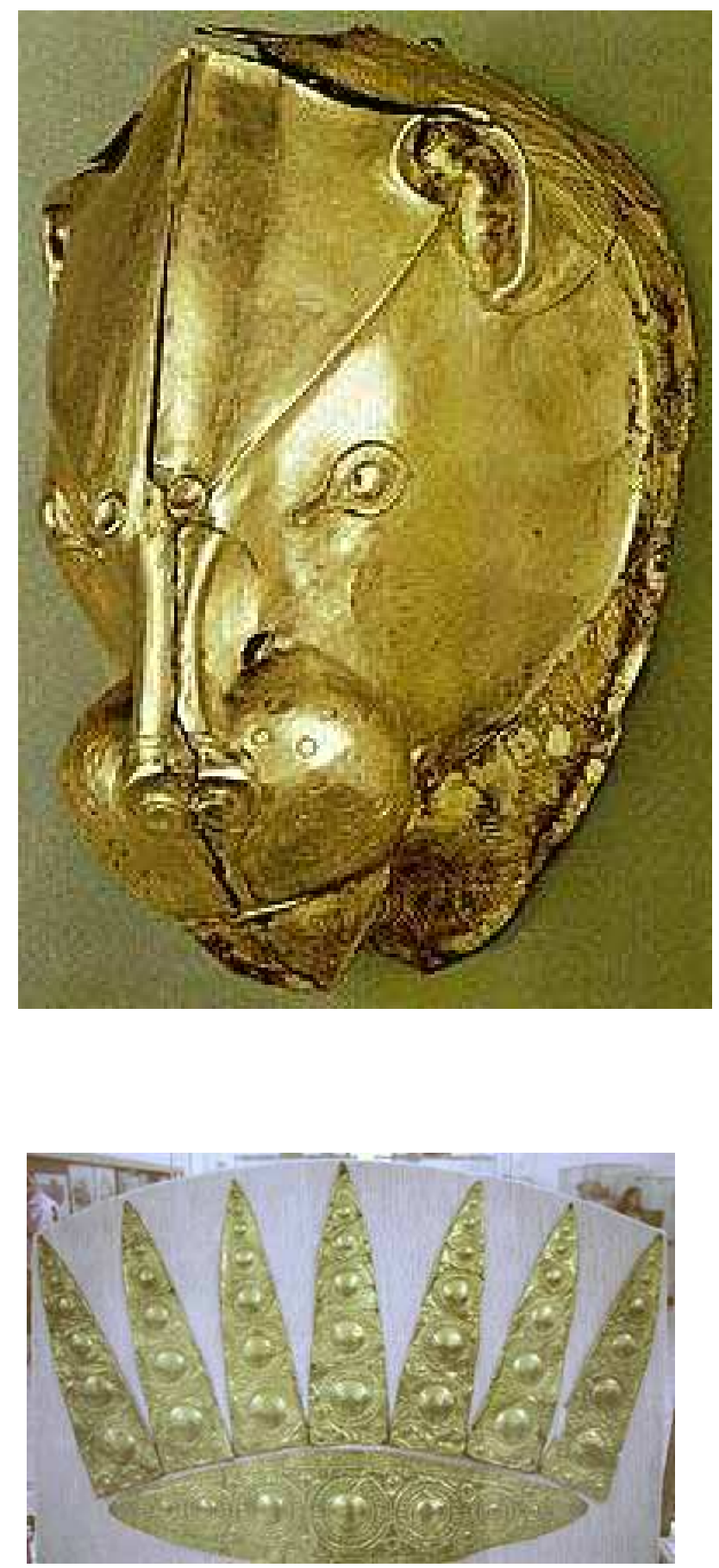

Fig. 31 Ríton de ouro na forma de cabeça de leão, proveniente do Túmulo IV no interior do Círculo Tumular A. Fonte da fiura:

$<$ http://www.ou.edu/finearts/art/a hi4913/aegeanhtml/mycobj4.htm 1>. Último acesso em $27 / 06 / 2008$.
Fig. 32: Diadema em ouro, proveniente do Túmulo III no interior do Círculo Tumular A. Fonte da figura:

$<$ http://www.ou.edu/finearts/art/ ahi4913/aegeanhtml/mycobj4.h tml>. Último acesso em 27/06/2008. 


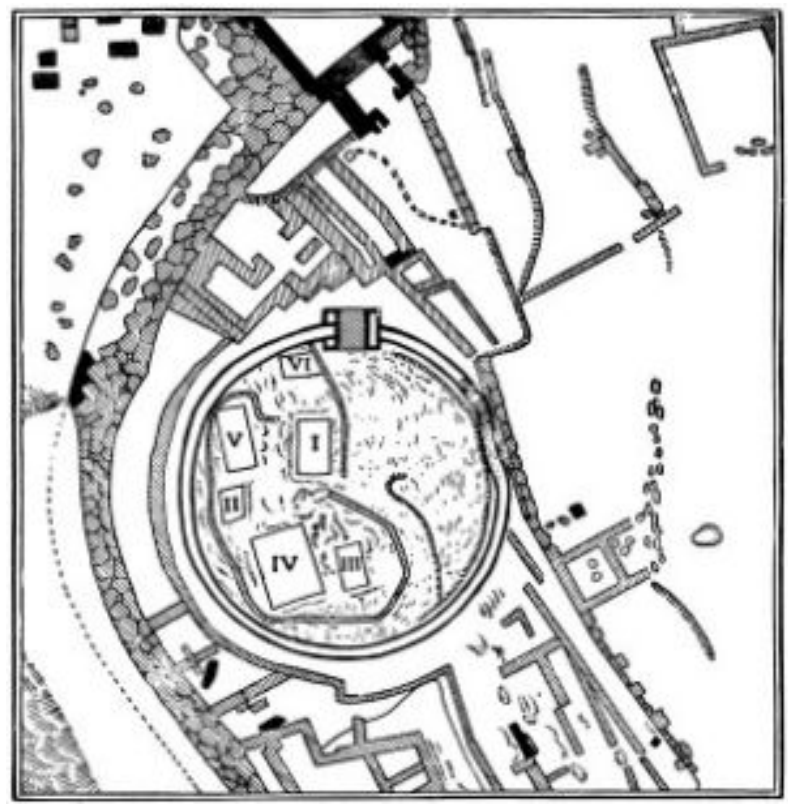

Fig. 33 Plano do Túmulo Circular A com o Sepulcro VI descoberto por Stamatákis. Fonte da figura: Tsountas, 1897, p. 86, fig. 33.

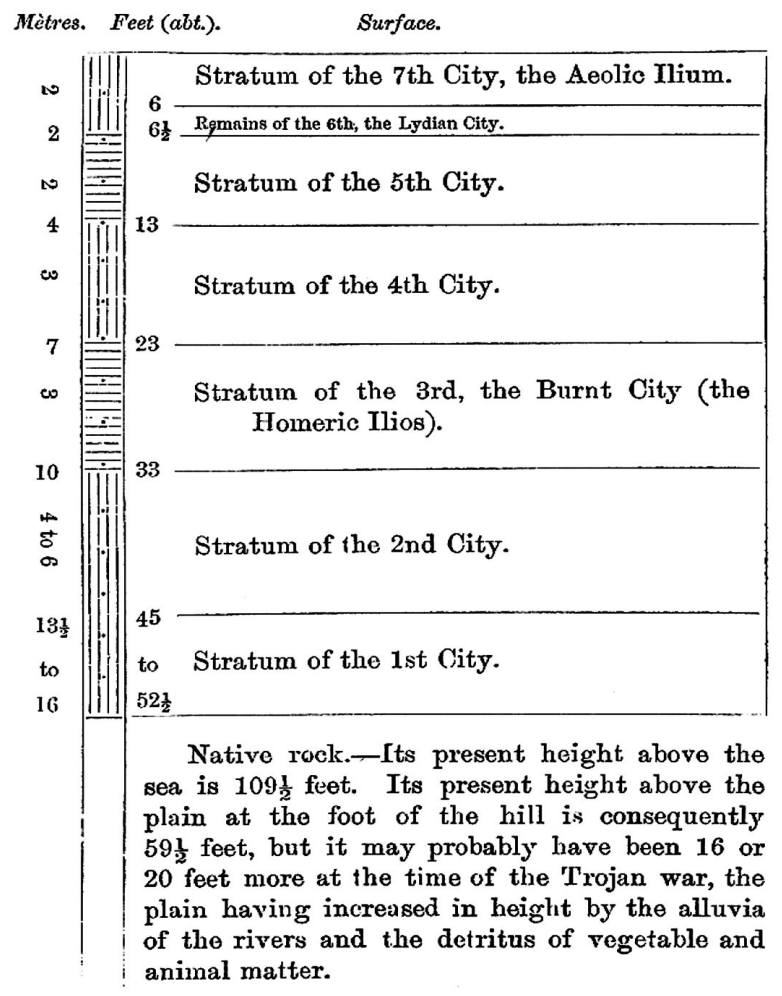

Fig. 34 Diagrama da sucessão de estratos em Hissarlik, estabelecido por Schliemann no final da segunda fase de escavações durante os anos de 1878-79. Fonte da figura: Schliemann, 1976 [1881], p. vii. 


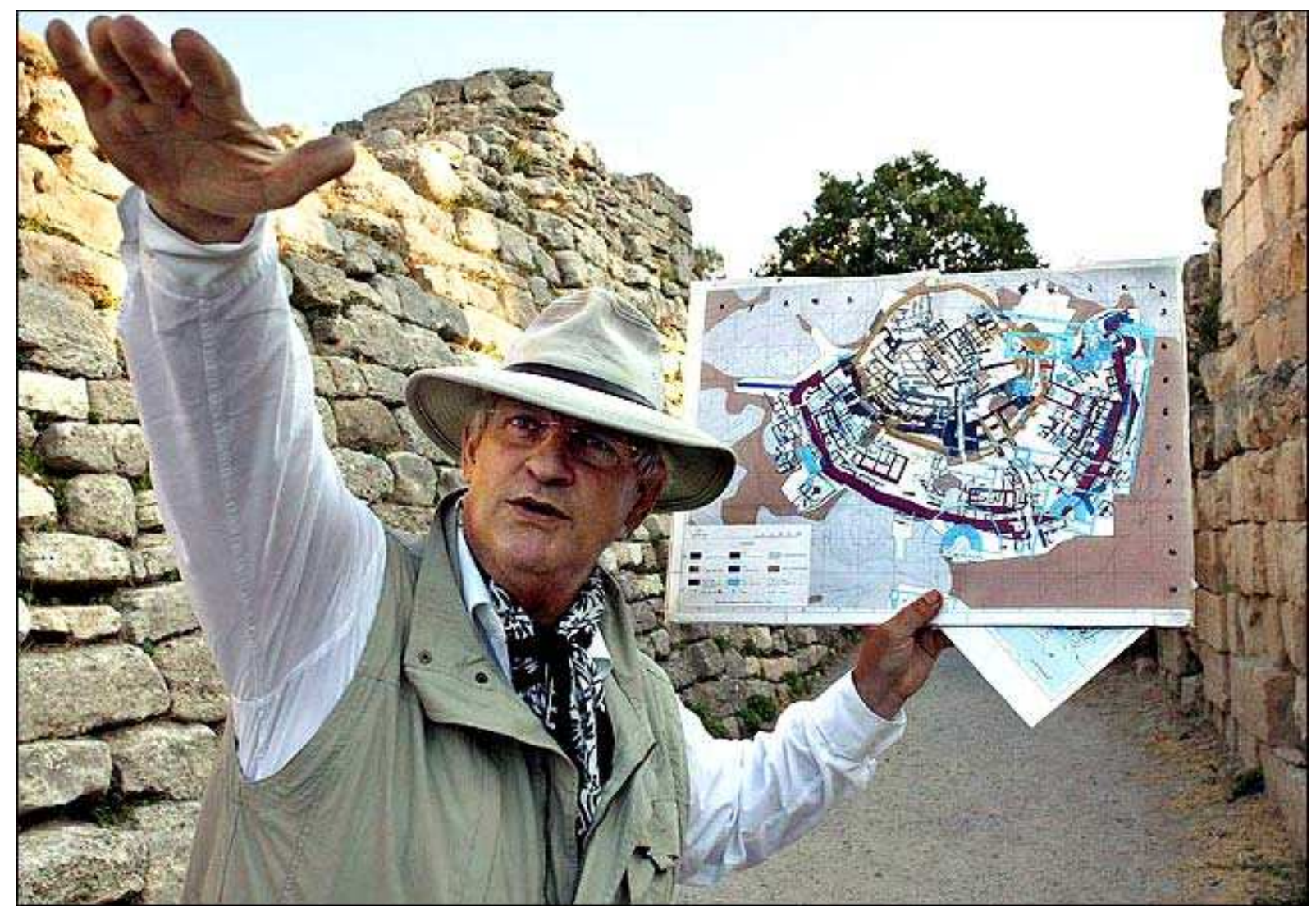

Capítulo 2

Blegen e Wace em Tróia e Micenas: o desenvolvimento de uma arqueologia 


\subsection{Tsountas em Micenas ${ }^{1}$}

Como foi mencionado no capítulo 1, entre os anos de 1877 e 1878, o arqueólogo grego Stamatákis, através da Sociedade Arqueológica de Atenas, foi quem se encarregou de continuar o trabalho iniciado por Schliemann em Micenas, que tinha voltado a Tróia para novas escavações.

Entre 1884 e 1902, outro jovem arqueólogo grego, Christos Tsountas (18571934), foi o responsável pelas escavações em Micenas. Apenas a região do Círculo Tumular A havia sido escavada por Schliemann e Stamatákis, e a cidadela em quase sua totalidade não havia sido explorada. Foi Tsountas quem revelou os muros em toda sua extensão (p. 73, fig. 1) e, em sua extremidade nordeste, encontrou uma passagem subterrânea que conduz a uma cisterna (fig. 1 e fig. 2), a qual possibilitava aos habitantes da cidadela sobreviver a períodos de cerco; revelou também a planta do palácio (fig. 3), que estava sob as fundações de um templo de data posterior, e sua semelhança com o palácio de Tirinto (TSOUNTAS, 1897, p. 63). Na parte leste da cidadela, ele escavou parcialmente um complexo de construções que foi denominado "Casa das Colunas" (fig. 1, $\mathrm{N}$ e U).

No lado de fora dos muros, no que se denomina "parte baixa da cidade", Tsountas abriu mais de 60 Túmulos em Câmara, um tipo de sepulcro que consiste em uma pequena caverna artificial cavada em pedra, cuja entrada é precedida por um drómos levemente inclinado para baixo, muito similar à thólos embora menos monumental; algumas eram marcadas por uma estela. Como um túmulo familiar, elas podiam ser usadas por um longo período de tempo. O morto era depositado no chão acompanhado de uma variedade de objetos votivos: vasos de cerâmica são os mais comuns, mas armas, diferentemente dos Túmulos em Poço do Círculo Tumular A, são bastante raras; a maior parte dos objetos encontrados é de uso pessoal como

\footnotetext{
${ }^{1}$ Para uma compreensão geral dos achados provenientes de Micenas durante as escavações de Schliemann e de Tsountas, consultar Tsountas (1897), também disponível em http://www.questia.com/PM.qst?a=o\&d=77466630 (último acesso em 10/09/2008).
} 
pentes, espelhos em bronze, selos, contas, ou ornamentos de pasta de vidro ou pedras semipreciosas; figurinhas de mulheres e animais também eram encontradas com certa freqüência. ${ }^{2}$

Do estudo dos diferentes tipos de túmulos encontrados em Micenas, Tsountas concluiu que o morto não era cremado, pois mesmo nas urnas, onde o morto era depositado, encontraram-se ossos. Essa incongruência em relação ao texto homérico, principalmente na passagem do funeral de Pátroclo no canto XXIII, em que é evidente a incineração do corpo, chamou-lhe a atenção (TSOUNTAS, 1897, p. 137)..$^{3}$

Além de Micenas, Tsountas conduziu importantes escavações na Grécia continental, identificando ainda mais sítios micênicos e do Período do Bronze Antigo como em Sesklo, Agios Andréas, Dimini e a thólos em Vaphio, próxima a Esparta, de onde retirou em 1889 as Taças Vaphio, dois recipientes em ouro com aproximadamente $9 \mathrm{~cm}$ de altura, cujo exterior é decorado com um baixo relevo representando a caçada de um touro (fig. 4 e 5). Também investigou sítios funerários em várias ilhas das Cíclades e, entre 1898 e 1899, essas investigações o levaram a cunhar o termo "Civilização Cicládica".

Tsountas já notara que os muros das várias Tróias com suas torres e as habitações em seu interior eram bastante distintos quanto à técnica de construção dos muros que circundavam Micenas e Tirinto e das habitações em seu interior, levando-o a interpretá-las como expoentes de culturas distintas.

Com as escavações de Tsountas, havia material suficiente para uma publicação consistente sobre o período que então viria a se denominar Micênico; a publicação, originalmente de 1893, recebeu uma versão em inglês em 1897 sob o título The Mycenaean Age: a study of the Monuments and culture of Pre-Homeric Greece. Esta foi a primeira publicação sistematizada sobre a civilização que se tornou conhecida como Micênica. Apesar da disponibilidade do material até então encontrado, um sistema satisfatório de seqüência cronológica para o continente,

\footnotetext{
${ }^{2}$ Para uma compreensão dos diferentes tipos de túmulos do Período Micênico e seu conteúdo, consultar a dissertação de mestrado defendida na Universidade de São Paulo por Torralvo (1993).

${ }^{3}$ Chamo atenção aqui para o capítulo seguinte (Capítulo 3) da presente dissertação, cujo tema é a relação entre os Funerais de Pátroclo descritos no canto XXIII da Ilíada e os achados arqueológicos.
} 
como Arthur Evans estava fazendo para a civilização Minóica, na ilha de Creta, não apareceu até depois da Primeira Guerra Mundial.

Durante os 20 anos que seguiram Tsountas, as investigações em Micenas se reduziram a explorações esporádicas realizadas por D. Evangelides em 1909, G. Rodenwaldt em 1911 e A. Keramopoulos em 1917.

No fim do século XIX, enquanto Tsountas publicava os resultados de suas escavações em Micenas e Evans escavava em Creta, outros pesquisadores estavam fazendo suas investigações arqueológicas em vários sítios pela Grécia continental e insular (Orchomenos, Tirinto, Gla, Tebas, Asine, Midea e Atenas); o conhecimento da cultura micênica crescia e a duração dessa civilização se tornava mais aparente, em grande parte graças aos achados em cerâmica. Schliemann já se referira à cerâmica como "a cornucópia da arqueologia", percebendo que grandes monumentos e objetos preciosos dizem bastante sobre o conhecimento técnico que uma civilização atingiu, mas a cerâmica é encontrada em muito maior abundância e em lugares mais distantes. Não apenas devido à sua abundância, mas ao seu uso e descarte, podendo ser quebradas com certa facilidade, elas fornecem uma datação relativa muito mais precisa do que objetos preciosos, que podem ser mantidos por muito tempo e passados de geração em geração dentro de uma mesma família. Assim, a cerâmica micênica foi submetida a um grande estudo comparativo por Arne Furumark (1903-1982) com uma tentativa de classificá-la com base em características técnicas e decorativas em uma seqüência cronológica. ${ }^{4}$ Além disso, achados de cerâmica micênica no Egito foram fundamentais para uma datação mais segura, principalmente a cerâmica encontrada nas escavações de Flinders Petrie em Tell-El-Amarna, cidade que tinha sido capital do Império do Faraó Akhenaton e ocupada por apenas 15 anos, entre 1379 e 1362 a.C (STUBBINGS, 1973, p. 40).

À medida que respondiam a determinadas questões, as escavações remetiam ainda a novas perguntas; por exemplo, eram os habitantes de Micenas gregos? Ainda não havia como responder a essa pergunta, embora não restassem muitas dúvidas que seus governantes tivessem sido alguns dos heróis homéricos. Mas

\footnotetext{
${ }^{4}$ Furumark, A. The Chronology of Mycenaean Pottery. Stockholm, 1941, apud Blegen, 1971 [1963], p. 183. Karo, G. Die Schachtgriber von Mykenae. Munich, 1930-1933, apud Symeonoglou, 1970, p. 285.
} 
essas perguntas se aproximariam de suas respostas 20 anos mais tarde, pois Micenas só voltará a ser sistematicamente escavada durante a década de 1920, após a Primeira Grande Guerra; e, durante esses vinte anos, outra estrela brilhou no campo da arqueologia: a Creta de Sir Arthur Evans, que dominou o cenário da pesquisa arqueológica no Mediterrâneo durante esse período.

\subsection{Wace em Micenas, Blegen em Tróia}

Enquanto Tsountas realizava suas pesquisas na Grécia continental, na Trôade, Dörpfeld levava a cabo duas grandes campanhas no monte de Hissarlik, em 1893 e 1894, após a morte de Schliemann, e publicou as correções e novos resultados numa grande obra intitulada Troja und Ilion. Durante essas duas campanhas, tendo em vista as descobertas anteriores, especialmente a construção em forma de mégaron no extremo sul da elevação associada ao depósito de Tróia $\mathrm{VI}$, que continha grande quantidade de fragmentos de cerâmica micênica, Dörpfeld descobriu as muralhas e as grandes casas de Tróia VI. A associação dessas construções à cerâmica micênica tornou claro que o sexto estabelecimento era contemporâneo às fortalezas de Micenas e Tirinto e, portanto, a sua identificação com a Tróia de Homero e de Príamo era inevitável. Embora longe de ser conclusiva, essa proposição prevaleceu até a década de 1930 (STUBBINGS, 1973, p. 35).

Entre 1920 e 1923, sob a coordenação de A. J. B. Wace, através da Escola Britânica de Atenas, as escavações foram retomadas em Micenas. O drómos e a soleira da porta do Tesouro de Atreu (cap.1, fig. 24) revelaram, sob os cuidados de Wace, um depósito que continha fragmentos cerâmicos datados estilisticamente do Heládico Tardio III (início do século XIV a.C.) e que Wace relacionou aos fragmentos que descobriu entre o Granário (fig. 1) e a Porta dos Leões (cap. 1, fig. 21) (Ibidem, p. 57-58). Tsountas já encontrara fragmentos semelhantes sob as paredes do Túmulo de Clitemnestra, no fim do século XIX, e esse mesmo tipo de cerâmica tinha sido encontrado por Flinders Petrie em Tell-El-Amarna, proporcionando assim, com base nas cronologias egípcias, uma datação bastante segura para essas construções. As datações, por sua vez, proporcionaram maior precisão e clareza 
quanto às diferentes fases de construção e conseqüentemente uma visão mais clara dos períodos sucessivos daquela cidade. Além dos túmulos que Wace explorou, as thóloi nos arredores de Micenas (fig. 6) foram reexaminadas e publicadas por ele, estabelecendo três diferentes fases de construção dos grandes monumentos de tal cidade. Assim, um modelo cronológico para Micenas estava sendo construído e o próximo passo seria voltar para Tróia e verificar até que ponto esta cronologia poderia contribuir para a história da ocupação em Tróia durante o mesmo período.

Depois das duas campanhas de Dörpfeld em Tróia, foi a vez da Expedição da Universidade de Cincinnati, com a ajuda do próprio Dörpfeld, liderada por W.T. Semple, tendo Blegen como diretor de campo, que já havia escavado em Kourakou, Zygouries e Prosymna. Dentre os anos de 1932 a 1938, sete campanhas de três a quatro meses cada uma foram realizadas e publicadas anualmente no American Journal of Archaeology. Entre 1950 e 1958 esses resultados foram publicados sob a direção de Blegen em 4 volumes denominados Troy: Excavations Conducted by the University of Cincinnati, 1932-38. Essa expedição conseguiu identificar não menos do que 46 estratos: cada uma das nove camadas principais, como já tinha sido notado por Dörpfeld, compunha-se de dois a nove estratos secundários, estas subdivisões indicando fases cronológicas mais curtas dentro dos períodos principais. Tornava-se claro que as camadas e períodos desde Tróia I até, e incluindo, Tróia V pertenciam a uma era que corresponde à Idade do Bronze Antiga (3000-1800 a.C.), enquanto o começo de Tróia VI marca a passagem para a Idade do Bronze Média. O sexto estabelecimento manteve-se sem uma verdadeira ruptura até parte final da Idade do Bronze Recente, embora o fim real dessa era se encontre representado pelas Tróias VIla e VIIb1 (BLEGEN, 1971 [1963], passim).

Nas escavações de 1894, a equipe de Dörpfeld já havia percebido que a sétima cidade ou Tróia VII era constituída de dois estratos muito bem definidos e muito diferentes, o último apresentando elementos até então estranhos às cidades anteriores. A Expedição de Cincinatti, então, comprovou essas diferenças e ao invés de denominá-los VII e VIII, atribuiu os nomes de Tróia VIla e VIlb, apenas por conveniência. Tróia VIla foi construída sobre os escombros do terremoto que teria destruído Tróia VI. E ao que parece, foi reconstruída pela mesma população, que 
teria conseguido se salvar. A reconstrução do muro levou mais ao sul a sua linha de fortificação, e foi reconstruído com pedras que caíram da construção anterior, misturadas a pedras menores, não trabalhadas, talvez por pressa na reconstrução, o que também é demonstrado pelas casas de Tróia VIla que são juntas umas às outras, como geminadas, e cujas paredes também foram construídas com o material dos escombros. Esse estabelecimento foi destruído pelo fogo e o que quer que tenha sobrevivido a ele, foi destruído pela construção de Tróia VIlb. Uma planta de uma casa sobreviveu, a Casa 700, que, como exceção, era uma casa grande com três cômodos que talvez tenha servido de 'snack bar' para os viandantes que entravam e saíam da cidadela: além de ficar à direita de quem entra na acrópole pelo Portão Sul, continha uma lareira oval sobre-elevada em 25 cm aproximadamente em relação ao chão de terra; junto à lareira, teria sido montado um moinho manual em tijolo cru e barro, e estava inclinado de maneira que a farinha nele moída caísse num depósito fundo em forma de bacia aberto no chão e revestido de barro liso; na parede oeste havia uma 'pia' de cozinha feita de pedra ligada a um escoadouro que atravessava a parede e corria para a rua.

Quase todas as casas de Tróia VIla continham píthoi enterrados no chão (fig. 7) para armazenagem que alcançavam até $2 \mathrm{~m}$ de altura. Há casas com até 20 píthoi, cujo chão tornava-se um crivo, mas como eram enterrados até a boca e sobre eles eram colocadas lajes de pedra como tampas, era possível andar pela casa. Estes potes foram utilizados através de todos os estabelecimentos de Tróia, mas apenas em Tróia VIla é que eles passaram a ser enterrados quase que totalmente e essa inovação provavelmente se deu a partir da necessidade de aproveitamento total de sua capacidade de armazenamento e para deixar livre o chão das casas, já bastante apinhadas.

Tal necessidade de espaço talvez não seja necessariamente uma decorrência de crescimento populacional, mas o resultado de alguma emergência que fez com que os habitantes da parte baixa da cidade externa aos muros tivessem necessidade de habitar intramuros, segundo Blegen (1971 [1963], p. 162). Os achados em cerâmica também nada acrescentaram em novidade à Tróia VI, como já tinha notado Schmidt, por cujas mãos passou cada fragmento e cada vaso 
desenterrado durante as campanhas de 1890, 1893 e 1894, e que publicou o Catálogo da Coleção Schliemann (apud ibidem, p. 163). Em Tróia VIla, a cerâmica mínia cinzenta aparece profusamente com o mesmo material, acabamento e formas típicas idênticos aos que predominavam na última fase de Tróia VI, e continuou a se usar cerâmica micênica, embora a Expedição de Cincinatti tenha encontrado um número menor de fragmentos dessa cerâmica em relação ao número de fragmentos de cópias locais, demonstrando uma queda nas importações desse tipo de cerâmica (ibidem, p. 164). As peças importadas correspondem ao tipo que Furumark classificou em Micênica III A e III B, e como não foi encontrado nenhum fragmento do tipo Micênico III C, supõe-se que Tróia VIla tenha encontrado seu fim antes que pudesse importá-la. De acordo com Furumark, a variação dos estilos cerâmicos do III A para o III B processou-se por volta de 1300 a.C., o que se pode então considerar uma data aproximada para o terremoto que arruinou Tróia VI, e o estilo Micênico III B aproxima a data de sua destruição por volta de 1250 a.C.; Tróia VIla durou pouco mais de uma geração e a sua destruição foi indubitavelmente, segundo a Expedição de Cincinnati, obra da intervenção humana, acompanhada de mortes e combates, como mostraram os restos de corpos que a mesma expedição encontrou entre os escombros, jazendo em posições que não seriam as comuns em enterramento, às vezes encontrando apenas o crânio esmagado, e logo depois o resto do corpo alguns metros adiante. Finalmente, Blegen havia encontrado a cidade que foi pilhada, capturada e depois imortalizada na llíada.

\subsection{Blegen em Pilos}

Se Tróia VIla foi a cidade destruída pela Guerra de Tróia, essa destruição não poderia ser posterior à queda dos grandes palácios do continente, como Micenas e Tirinto. Logo, Blegen precisava novamente voltar-se para a Grécia continental e, mais precisamente, para um sítio onde a estratigrafia não tivesse sido arruinada pelos primeiros escavadores; mas qual das cidades homéricas seria a escolha mais apropriada? Pilos, a cidade de Nestor, seria perfeita se a sua localização exata fosse conhecida; sabia-se apenas que ficava na Messênia, sudoeste do Peloponeso. 
Diferentemente de Micenas e exatamente como Tróia, não havia qualquer certeza sobre sua localização.

Como Schliemann, tendo Homero como guia, em 1939, mais de 70 anos depois da primeira aventura daquele através da planície troiana, Blegen e Kouroniotis, um arqueólogo grego que havia descoberto duas thóloi na região da Messênia, prospectaram a nordeste da Baía de Navarino, com a ajuda de habitantes locais que sabiam onde havia reminiscências de antigas ocupações. No final de dez dias, oito sítios foram encontrados, dentre eles um a $10 \mathrm{~km}$ da baía cuja vista era espetacular e que Blegen pensou ser um excelente lugar para se construir um palácio. Nesse monte denominado Ano Englianos, ao abrir a primeira trincheira, Blegen se deparou com os restos de um palácio muito semelhante ao de Micenas e ao de Tirinto; além disso, em torno de 600 tabletes e fragmentos na escrita Linear B. Blegen, então, publicou os achados em The Palace of King Nestor at Pylos.

\subsection{Wace retorna a Micenas}

Wace voltou novamente a Micenas, em 1939, pela Escola Britânica de Atenas para realizar novos estudos na cidadela e no Tesouro de Atreu. Escavou a Casa das Colunas encontrada por Tsountas, em 1895, mas nunca publicada até então, particularmente interessante por ser uma grande construção contemporânea ao grande mégaron de Tirinto e habitada até o incêndio de Micenas no século XII a.C. (WACE, 1939). Nesse ano também descobriu a oeste da porta dos Leões, fora dos muros ciclópicos e ao norte do Círculo Tumular, 15 túmulos, de datas entre o Heládico Médio e o Heládico Tardio II. A descoberta desses túmulos tão próximos aos Túmulos em Poço demonstrou que o cemitério pré-histórico de Micenas, datado do Heládico Médio e do Heládico Tardio I e II, foi cortado pelo muro ciclópico quando a porta dos Leões e os muros adjacentes foram erigidos no início do Heládico Tardio III (Ibidem, p. 211).

No Tesouro de Atreu, a uma distância de $10 \mathrm{~m}$ da fachada do túmulo tanto no lado sul quanto norte do drómos, foi encontrado num buraco na rocha formando um tipo de grande "bóthros", que é um enorme depósito de fragmentos cerâmicos, 
figurinhas de terracota, ossos de animais, conchas e outros descartes domésticos. Este depósito foi interpretado por Wace como descarte jogado de cima do topo do monte e mostrou que um importante quarteirão residencial teria coroado tal elevação acima do túmulo. $O$ depósito antedatava o túmulo e como ele continha cerâmica do início do Heládico Tardio, Wace revisou sua própria datação do túmulo e propôs a data entre 1350-1300.

As escavações em Micenas foram interrompidas em decorrência da II Guerra Mundial, e só puderam ser recomeçadas em 1950. Nesse ínterim, a cerâmica micênica descoberta até então foi sistematicamente estudada e classificada em Heládico Tardio I, II e III por Furumark e que tornou possível o estabelecimento da cronologia para os sítios do período micênico, inclusive Tróia.

Em 1951, Wace publicou um artigo, juntamente com a publicação da campanha de escavação realizada em 1950 em Micenas, sobre a casa homérica, chamando atenção para o fato de algumas casas apresentarem escadas e cômodos superiores ou inferiores. E que, quando Homero, na llíada (VI, 288), usa a palavra $k a t a b h \xi$ et 0 , ele realmente quer dizer que Hécuba desceu as escadas do mégaron até uma dispensa para pegar seu melhor péplos (vestimenta) para dedicar a Atena. Wace então concluiu que devia ser comum que a casa micênica tivesse três andares: um porão, o térreo (que seria o andar principal) e um andar superior. Ele ainda acrescenta que seria bastante razoável, pois a maior parte das cidades do período micênico está localizada sobre montes, como a própria Micenas. Uma passagem no mesmo canto ( $\mathrm{VI}, 316)$ expressa o que parece ser as três principais partes de uma casa: a a $\mu \mathrm{l} \mathrm{h/(pátio),} \mathrm{dw} \mathrm{ma} \mathrm{(ala} \mathrm{social)} \mathrm{e} \mathrm{qa} \mathrm{l} \mathrm{a} \mathrm{moj} \mathrm{(aposentos).} \mathrm{Isso}$ é bem ilustrado pela Casa da Colunas, que tinha um porão, um andar térreo e pelos menos um andar superior, e também pelo Granário, que tinha porão e dois andares superiores.

Concomitantemente às escavações da Escola Britânica, o arqueólogo grego Papadimitríou, da Sociedade Arqueológica de Atenas, assistido por Mylonás, então Professor da Washington University de St. Louis, e que fora pupilo de Tsountas na sua juventude, durante os anos de 1952-54, identificaram o Círculo Tumular B (fig. 6 item 5; fig. 8) e se encarregaram de escavá-lo. Dentro do Círculo B, eles 
descobriram mais de 20 túmulos variando em tamanho e conteúdo, de pequenas cistas do Heládico Médio com um único enterramento a grandes túmulos coletivos com oferendas votivas bastante similares às do Círculo Tumular $A$, e também marcadas por estelas apresentando espirais e cenas de caça em relevo; adagas, espadas, pontas de lanças eram do mesmo tipo. Os túmulos foram denominados pelas letras do alfabeto grego.

Entre 1959 e 1969, Lord William Taylour da Escola Britânica de Atenas, em conjunto com a Sociedade Arqueológica de Atenas, escavou a região entre a Casa do Vaso do Guerreiro e a Casa de Tsountas, que tinha permanecido até então inexplorada.

\subsection{Ventris, Chadwick e a Linear B}

A existência da escrita Linear B já era conhecida desde as escavações de Evans em Cnossos entre 1900-10; uma grande quantidade de tabletes foi revelada nessas escavações e também nas escavações de Tirinto, Orcômenos, Pilos e Micenas. Além dos tabletes e nódulos em argila, há cerca de 150 vasos com inscrição pintada, a maior parte deles proveniente dos sítios que já apresentavam tabletes. Como os tabletes são difíceis de distinguir da terra removida numa escavação, é bastante provável que muitos tenham se perdido nas primeiras explorações de Micenas e Tirinto.

A datação dos tabletes e de vasos inscritos encontrados no continente, ao menos daqueles passíveis de serem datados, é atribuída, em sua maioria, à segunda metade do século XIII a.C.

Foi apenas em 1951 com a publicação dos tabletes de Pilos que os esforços para seu deciframento tiveram início. Michael Ventris era um jovem arquiteto fascinado pelo mistério da escrita Linear $B$ desde a sua adolescência, quando assistiu a uma conferência proferida por Sir Arthur Evans na Burlington House, em 1936. O seu deciframento, com a ajuda de Chadwick, mostrou que a escrita representava uma forma de grego, pois palavras como wanax, utilizadas por Homero, tinham sua representação escrita nos tabletes, além da forma do genitivo 
em -oio e da terminação -phi que irá desapareceria nos dialetos do período clássico.

Talvez a maior conseqüência do deciframento da Linear B tenha sido que ela expressava uma espécie de grego e, conseqüentemente, a língua falada pelos habitantes dos palácios onde tabletes em Linear B foram encontrados deveria ser uma forma de grego, estabelecendo uma ligação entre eles e os gregos além do compartilhamento do território ocupado por ambos em épocas diferentes, mas, até certa medida, um compartilhamento cultural. Embora os tabletes não apresentassem conteúdo literário ou religioso e fossem inventários da contabilidade palacial, um pouco da organização social e política pôde ser esclarecida à luz do deciframento. Tanto Cnossos quanto Pilos, dois lugares de onde vem a maior parte dos tabletes, eram governadas por 'monarquias', pois há tabletes provenientes de ambas as cidades que mencionam wanax (uma espécie de governante com poderes reais), 0 que não é surpreendente diante dos complexos palaciais encontrados em ambas e que demandariam certa organização burocrática.

Há também um oficial denominado lawagetas, que parece ser o cargo imediatamente abaixo do wanax e que é completamente desconhecido pelas obras de Homero, nas quais também não encontra um equivalente. Ambos parecem possuir um témenos, o termo que designa a propriedade do governante ou chefe de homens em Homero. A questão da propriedade no decorrer do período micênico ainda é bastante debatida e o que se sabe a partir dos tabletes é que elas eram divididas em dois tipos: ke-ke-me-na que designa a terra que pertence à comunidade; e ke-ti-me-na, que é a terra de propriedade privada. Há ainda uma série de títulos menores ainda não definidos pelos estudiosos. Talvez o mais interessante deles seja o basileus que em tempos micênicos seria um título local e que não chegaria perto do poder expresso pelo wanax.

Alguns tabletes de Pilos fornecem informações acerca da disposição de unidades militares. Há também tabletes que apresentam nomes como Aquiles, Heitor e Teseu referindo-se a pessoas comuns (VENTRIS \& CHADWICK, 1973, p. 92-105). 
A origem da Linear B remonta a outra forma de escrita, a Linear A (TREUIL, p. 1989, p. 251), pois dos 87 ideogramas silábicos daquela escrita, 64 apresentam um ancestral em Linear A e somente 23 parecem ser originais (Ibidem, p. 394).

A partir do deciframento da Linear B, uma relação entre uma forma 'arcaica' de grego e o grego utilizado por Homero era inevitável. A existência do digama (uma espécie de 'w' que soa como no nome próprio 'William') na Linear B e a solução que a possível utilização desse som trouxe para versos em que o pé hexamétrico em Homero simplesmente parecia não estar correto, provava uma continuidade entre a língua falada pelos micênios e a língua de Homero. A explicação seria de que o bardo do século VIII a.C., que não pronunciava o ' $w$ ', cantava versos compostos originalmente quando tal som ainda era pronunciado ou que ele compunha $e$ cantava à moda de tal época (LATACZ, 2004 [2001], p. 163). A variedade de Homero preservara um estado da língua grega que pertencia a um passado que distava em torno de 500 anos dos poemas homéricos.

\section{6 $O$ estado da arte em Micenas}

Micenas atualmente é escavada por S. lakovídhis e C. Maggidis, atual professor da Dickinson College na Inglaterra. Em mais de 130 anos de pesquisa, em torno de $70 \%$ da cidadela foi escavada. O tipo de arte e cultura revelado por Schliemann e Tsountas veio a ser conhecido como 'micênico', pois foram reveladas naquela cidadela pela primeira vez, e desde então as semelhanças encontradas em outras partes da Grécia alargaram o termo, fazendo-o abranger a Hélade Continental do final da Idade do Bronze (1620-1120 a.C.) em sua totalidade. $\mathrm{Na}$ verdade, o termo 'micênico' caracteriza a cultura presente na Grécia durante a maior parte do segundo milênio a.C., mais precisamente a sua segunda metade.

Os achados no interior dos Túmulos em Poço são indícios de que no final do século XVII e início do século XVI a.C. Micenas era uma cidade rica e poderosa - a quantia de objetos em ouro escavada em Micenas é maior do que a quantia escavada em todos os outros sítios micênicos do continente juntos - e à altura do epíteto homérico 'rica em ouro'. 
O início da Idade Micênica se dá quando a cultura local, a partir das influências da cultura minóica, gradualmente se desenvolveu até que, em torno de 1450 a.C., a cultura micênica passou a se desenvolver numa linha diferente. Essa data marca um período de expansão e influência dos micênios nas partes ocidental e oriental do Mediterrâneo - seus produtos como óleo de oliva, perfumes, vinho, cerâmica, dentre outros são encontrados no Egito, Palestina, Síria, em toda a costa ocidental da Ásia Menor, nas ilhas adjacentes de Rodes e Samos, no sul da Itália e na Sicília; em troca, eles traziam cobre, ouro, estanho, marfim, ervas aromáticas e idéias artísticas e culturais. Seus postos de troca logo se tornaram colônias, em geral subjugando e substituindo postos que eram minóicos, ou tirando vantagens de acidentes naturais como a erupção vulcânica de Tera e o terremoto que destruiu palácios cretenses em torno de 1475 a.C.; assim, Micenas conquistou Cnossos, de onde eles governaram sobre uma grande parte de Creta por algumas gerações.

Os séculos XIV e XIII a.C. continuaram a ser prósperos para os micênios. Foi durante esse período que um número de cidadelas foi circundado por muros ciclópicos e palácios foram erigidos em várias partes da Grécia; ao mesmo tempo, a maior parte das thóloi em Micenas foi construída, como o Tesouro de Atreu e o Túmulo de Clitemnestra, e também o Tesouro de Mínias em Orcômenos. A organização política tinha seu governante expresso pelo termo wanax e havia uma hierarquia burocrática bem estabelecida durante esse período. As centenas de tabletes em Linear B, encontradas em Pilos e Cnossos, contabilizando as posses do wanax, oferecem uma visão, ao menos parcial, dessa organização política, da posse de terras, da organização religiosa e da divisão da população em classes e espécies de guildas. Os tabletes também indicam que além de guerreiros e comerciantes, os micênios eram agricultores e pastores; cultivavam o trigo, oliveiras, figo, amêndoas; os animais incluíam ovelhas, carneiros, porcos, até mesmo cavalos, que eram um item bastante valorizado. Mylonás (1985, p. 94) argumenta que a escrita Linear B tenha se desenvolvido da Linear A minóica a partir da ocupação dos micênios em Cnossos para que pudessem registrar as posses do palácio. Logo, os micênios teriam adotado dos cretenses, que provavelmente não eram falantes da língua grega, uma escrita silábica utilizada lá, a Linear A, que ainda não foi decifrada, e a 
usaram para registrar documentos em sua própria língua que seria uma forma de grego.

Durante o mesmo século XIV, mais precisamente na segunda metade, algumas casas de Micenas foram destruídas pelo fogo, algumas áreas foram abandonadas e até mesmo uma parte do palácio foi destruída; mas a destruição maior ocorreu no início do século XII a.C., quando o palácio foi novamente incendiado e um número de construções no interior da cidadela e na sua parte externa foi destruído pelo fogo. As causas dessa destruição ainda é motivo de discordância, mas a contemporaneidade às destruições de outras cidades do mundo micênico traz a unanimidade em relação à queda do poder micênico sobre a região. E é nesse mesmo período (em torno de 1200 a.C.) que a data da Guerra de Tróia tem sido estabelecida e para fazer essa ponte entre Micenas e Tróia é que se faz mister discorrer finalmente sobre esta última.

\subsection{O estado da arte em Tróia}

Desde 1988, uma expedição internacional reiniciou o trabalho em Tróia sob a direção de Manfred Korfmann (cuja fotografia está no frontispício deste capítulo) da Universidade de Tübingen com a colaboração da Universidade de Cincinnati e outros especialistas. Korfmann, diferentemente de seus antecessores em Tróia, nunca foi um classicista; ele era um pré-historiador que iniciou sua pesquisa em Hissarlik depois de ter conduzido escavações na Anatólia central pelo Instituto Arqueológico Alemão, e que veio ao Dardanelos para estudar os movimentos, as

relações comerciais e as estruturas de poder no ponto exato onde Ásia e Europa se tocam numa época muito anterior ao florescimento da cultura greco-romana. Pela primeira vez, Tróia seria escavada por alguém que não necessariamente tinha Homero como pressuposto e sua perspectiva não era exatamente de alguém que via Tróia a partir da Grécia. Isso significou uma mudança considerável na perspectiva (LATACZ, 2004 [2001], p. 20).

As 15 campanhas levadas a cabo por Korfmann (1988-2002) receberam, além do financiamento das universidades envolvidas, um patrocínio da empresa 
automobilística Daimler-Chrysler, que possibilitou aplicar métodos e técnicas modernos para resolver velhos problemas deixados por seus antecessores. Um desses problemas era a existência ou não de habitações fora dos limites do monte de Hissarlik. Tanto Schliemann como Dörpfeld já tinham notado que o sexto estabelecimento (Tróia VI/Vlla) (fig. 9) parecia não se limitar ao monte de Hissarlik, mas se estendiam pelos arredores da montanha; a expedição americana tinha descoberto, em 1934, um cemitério que pertenceria à Tróia VI, mas se localizava a cerca de $500 \mathrm{~m}$ da cidadela. A questão seria se entre a colina de Hissarlik e o cemitério existiriam habitações. Korfmann, em seu primeiro ano de escavação (1988), utilizando-se de uma nova técnica de produção de imagem (geo)magnética, um tipo de raio $X$ fotográfico, conseguiu obter imagens de estratos inferiores sem perturbar o estrato superficial que apresentava as construções de Tróia VIII ou a Tróia Greco-Romana. Por sua vez, o fato de haver uma parte baixa da cidade levava a inferência sobre a existência de um muro que a protegeria e, no ano seguinte, usando um magnetômetro de césio ainda mais potente do que o do ano anterior, a equipe descobriu um muro cerca de $400 \mathrm{~m}$ a sul dos muros da cidadela VI. Três escavações-teste foram feitas em tal área em 1993, mas o que emergiu não foi exatamente um 'muro', e sim uma trincheira, parte de um sistema defensivo que circundava uma área de $200.000 \mathrm{~m}^{2}$ (fig. 10). A estimativa populacional de Korfmann para Tróia VI de cerca de 6.000 a 7.000 habitantes se tornava bastante plausível e, mais do que isso, a hipótese de que o tipo de organização urbana de Tróia se assemelhava mais ao anatólio do que ao micênico aproximava Tróia dos centros comerciais do Oriente Antigo. Embora Tróia Vl/Vlla apresente o mégaron, construção característica dos palácios micênicos, as trincheiras não fazem parte do sistema de construção micênico, mas são típicos das cidades da Anatólia. Donald F. Easton, que fazia parte da equipe de Korfmann, logo notou que a cerâmica acinzentada denominada Mínia, que abunda no sítio de Tróia desde Tróia V, por sua forma e técnica de manufatura, diferente do que Blegen tinha assumido, não foi padronizada a partir de modelos da Hélade Continental, mas em modelos anatólios. De toda a cerâmica recolhida durante as escavações de 1988-95, apenas $1 \%$ era cerâmica micênica (e a maioria era imitação dela). A cerâmica acinzentada Mínia 
então recebeu um outro nome: cerâmica acinzentada anatólia. As práticas funerárias como a cremação do morto ao invés da inumação também é de origem anatólia. Dessa maneira, Tróia deixava de ser uma cidadela fortificada no topo de um monte, para se caracterizar como um grande e importante centro urbano para os padrões daquela época (LATACZ, 2004 [2001], p. 22-37).

Se a organização urbana era tão semelhante às cidades da Anatólia, a sua organização política não deveria ser diferente, pensou Korfmann (Ibidem, p. 39). Mais do que isso, o tamanho de Tróia VI/VIla sugeria que ela deveria ser mais do que um centro agrícola ou pastoril, e que sua magnitude deveria ser explicada em termos comerciais, principalmente por sua privilegiada posição próxima ao mar (fig. 11), numa área de passagem. Logicamente, Tróia não deve ter passado despercebida aos hititas, proeminentes na Anatólia durante o período (Ibidem, p. 73).

Korfmann, baseando-se em textos hititas e em suas investigações arqueológicas, defendeu que a guerra da qual Homero fala aconteceu no final de Tróia VIla, em torno de 1200-1180 a.C (fig. 12). O estudo dos textos e inscrições hititas tem elucidado bastante a geografia do oeste da Anatólia durante a Idade do Bronze Tardia (c. 1300-1200 a.C.). Há poucas dúvidas de que a Wilusa/Wilusija dos textos hititas corresponda ao termo ĺlios e que Tarwisa/Tru(w)isa corresponda ao termo Tróia; e é provável que os termos Lazpa, Apasa e Millawanda/Milawata, conhecidos também através dos textos hititas, sejam respectivamente Lesbos, Éfeso e Mileto (Ibidem, 2004 [2001], p. 75-96). Os textos hititas ainda falam de uma terra de Ahhiyawa que corresponderia ao termo Acaia.

\subsection{Ahhiyawa e Wilusa: intersecções}

A ascensão repentina da grande riqueza indicada pelo conteúdo dos Túmulos em Poço é vista em geral como o resultado de um grande poder militar alcançado por Micenas durante tal período. Um vaso em forma e decoração no estilo do Heládico Tardio II A (c. 1525-1450 a.C.), mas fabricado em argila local (da região da Anatólia), foi encontrado em Tróia, enquanto um vaso hitita em prata foi encontrado 
no Túmulo em Poço IV de Micenas. A grande muralha defensiva de Tróia VI foi erigida nesse período. No reino hitita de Tudhaliya II (c. 1400 a.C.), um homem da Ahhiya(wa), Attarsiya, é referido como comandante de um destacamento de infantaria mais 100 carros na costa da Anatólia. Uma espada de tipo micênico foi dedicada por Tudhaliya a uma divindade como agradecimento por uma vitória, e uma tigela hitita incisa apresenta uma cena de um guerreiro vestindo o que seria uma vestimenta micênica. O Heládico Tardio III A2 (c. 1380-1310 a.C.) (WEINER, 2003) é o período do grande impacto da expansão micênica na costa da Anatólia e no Dodecaneso. Durante o Heládico Tardio III A e B, a interação ia além de trocas e emulação artística, chegando às práticas mortuárias: um cemitério na costa próxima a Tróia, que continha cerâmica do Heládico Tardio III A e B, revelou uma mistura de inumações e cremações em crateras acompanhadas de armas.

No final do Heládico Tardio III B e início do III C, o sistema palacial de Micenas, como dito acima, entrou em colapso e com ele o sistema da escrita burocrática. Ataques provenientes do norte e/ou dos "Povos do Mar", lutas internas ou entre os palácios, terremotos, pragas, mudanças climáticas, colapso econômico ou do sistema comercial têm sido as hipóteses propostas, quer individualmente, quer em conjunto, para o fim do sistema palacial micênico. Nesse período, o equipamento militar recebeu grande influência do norte (mas qual norte?). Nesse contexto, é possível imaginar várias razões estratégicas para uma guerra entre Wilusa e Ahhiyawa. Pouco tempo separa a expedição contra Tróia e a destruição de Pilos, por exemplo. Tucídides (1.12) conta que o retorno dos gregos após a Guerra de Tróia levou vários anos, durante os quais guerras civis ocorreram entre algumas cidades, causando o movimento da população para novos lugares.

O Vaso dos Guerreiros (cujo detalhe compõe a capa desta dissertação) ${ }^{5}$ proveniente de Micenas é datado de 50 anos aproximadamente após tais destruições que marcam o fim do Período Palacial Micênico, período referido como Heládico Tardio III C (c. 1200-1100 a.C.), e é perfeitamente plausível que ele remeta a eventos de um passado recente.

\footnotetext{
${ }^{5} \mathrm{O}$ frontispício do capítulo 4 apresenta uma visão total da face A do Vaso dos Guerreiros.
} 


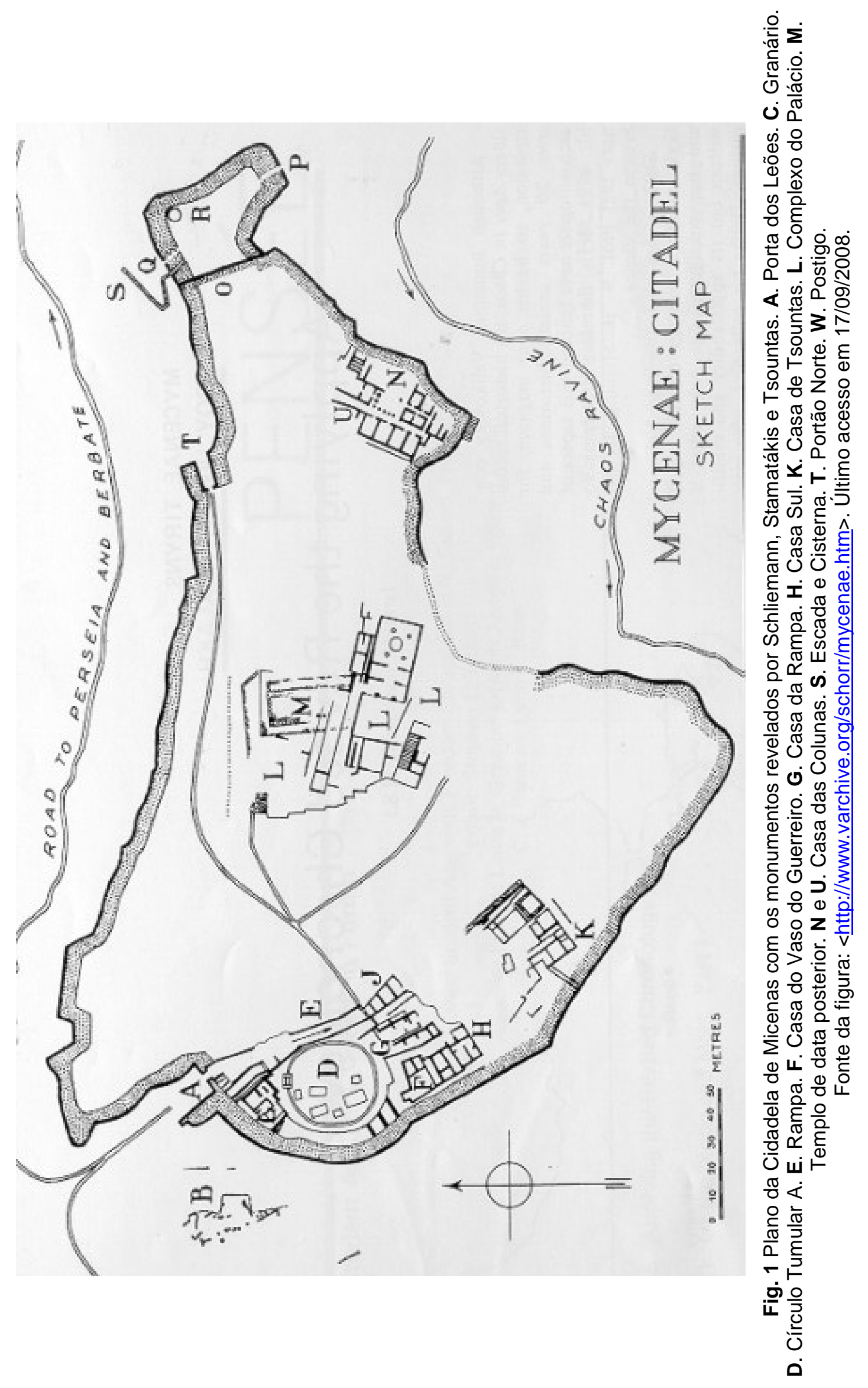




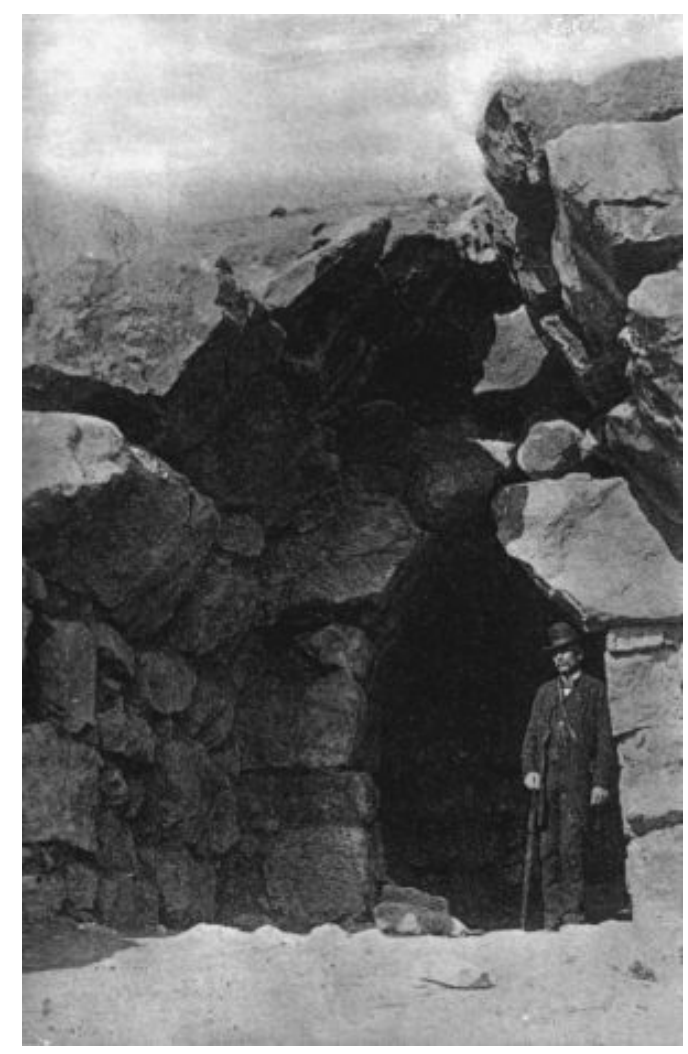

Fig. 2 Tsountas à entrada da cisterna em Micenas. Fonte da figura: Tsountas, pl. VII.

Fig. 3 Plano do Palácio de Micenas:

1. Propileu Noroeste.

2. Canto Noroeste.

3. Grande Corredor.

4. Entrada Oeste.

5. 'Guard Room'.

6-6a. Corredor Sul.

7. Ante-sala.

8. Corredor.

9. Grande Pátio.

10. Mégaron.

11. 'Guest rooms'.

12. Ecada Sudoeste.

13. Escada.

14. Canto de um cômodo.

15. Fundações do Período Helenístico. 16. Ponto de onde se inicia a visita pelo lado leste.

Fonte da figura:

Mylonas, 1985, p. 59.

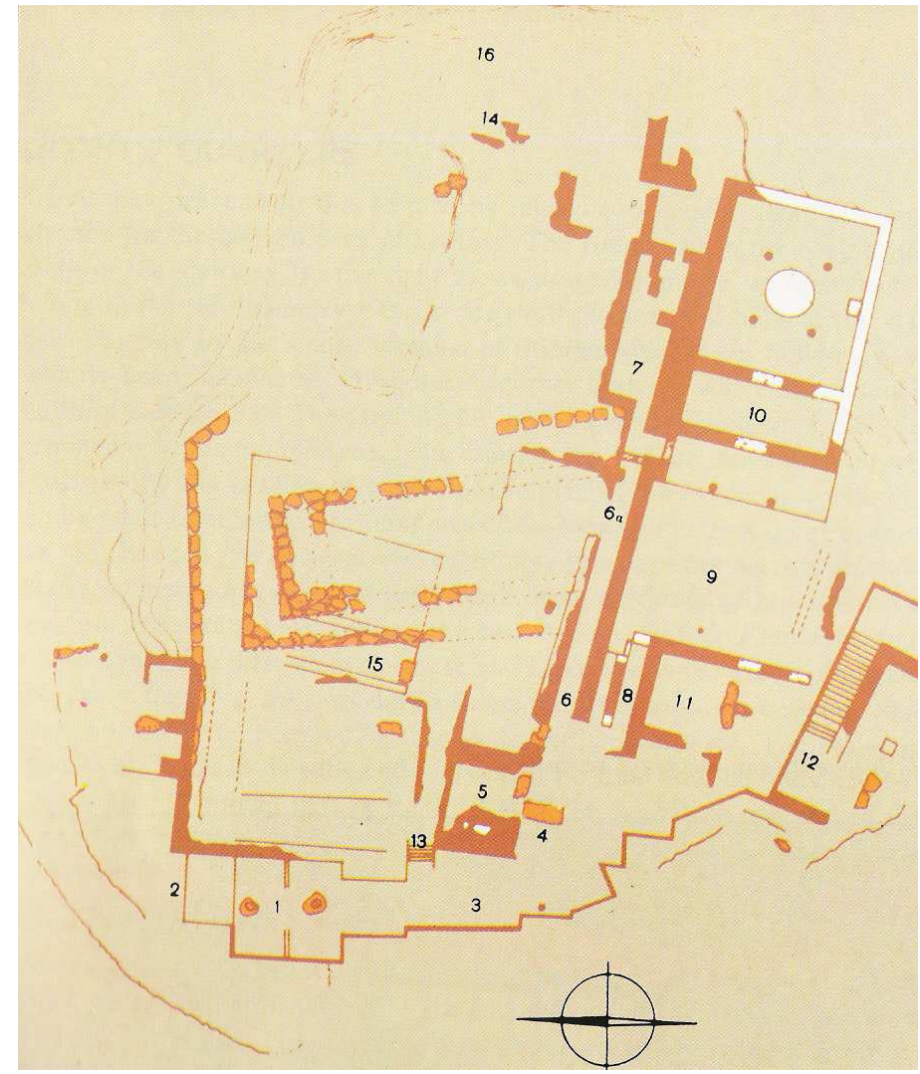




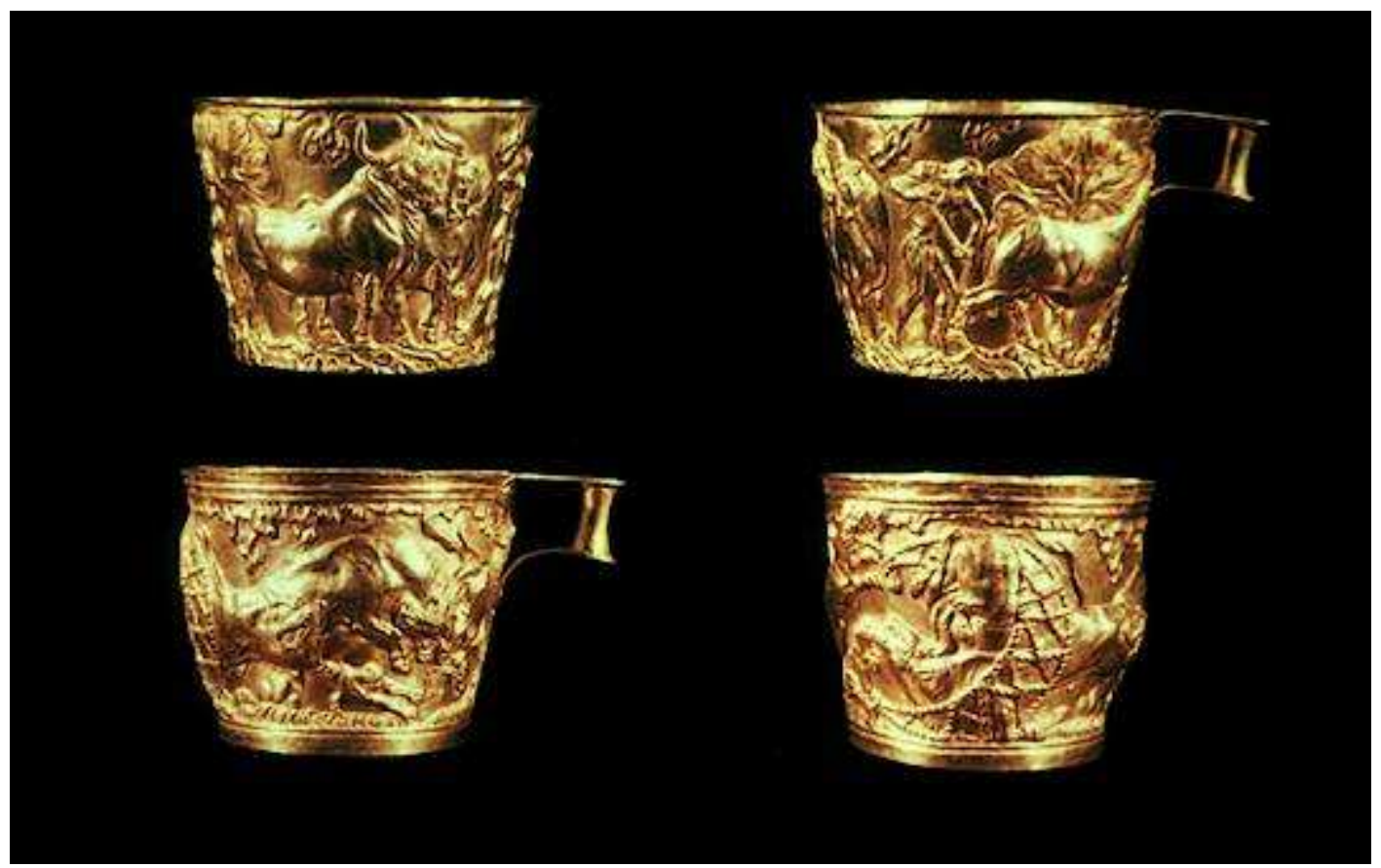

Fig. 4 Canecas em ouro de Vaphio (1500-1400 a.C.). Provenientes de Vaphio, nas proximidades de Esparta. Altura: $8,9 \mathrm{~cm}$. Museu Arqueológico Nacional de Atenas. Fonte da figura: $<$ http://images.encarta.msn.com/xrefmedia/sharemed/targets/images/pho/t014/T014535A.jpg >. Último acesso em 18/09/2008.

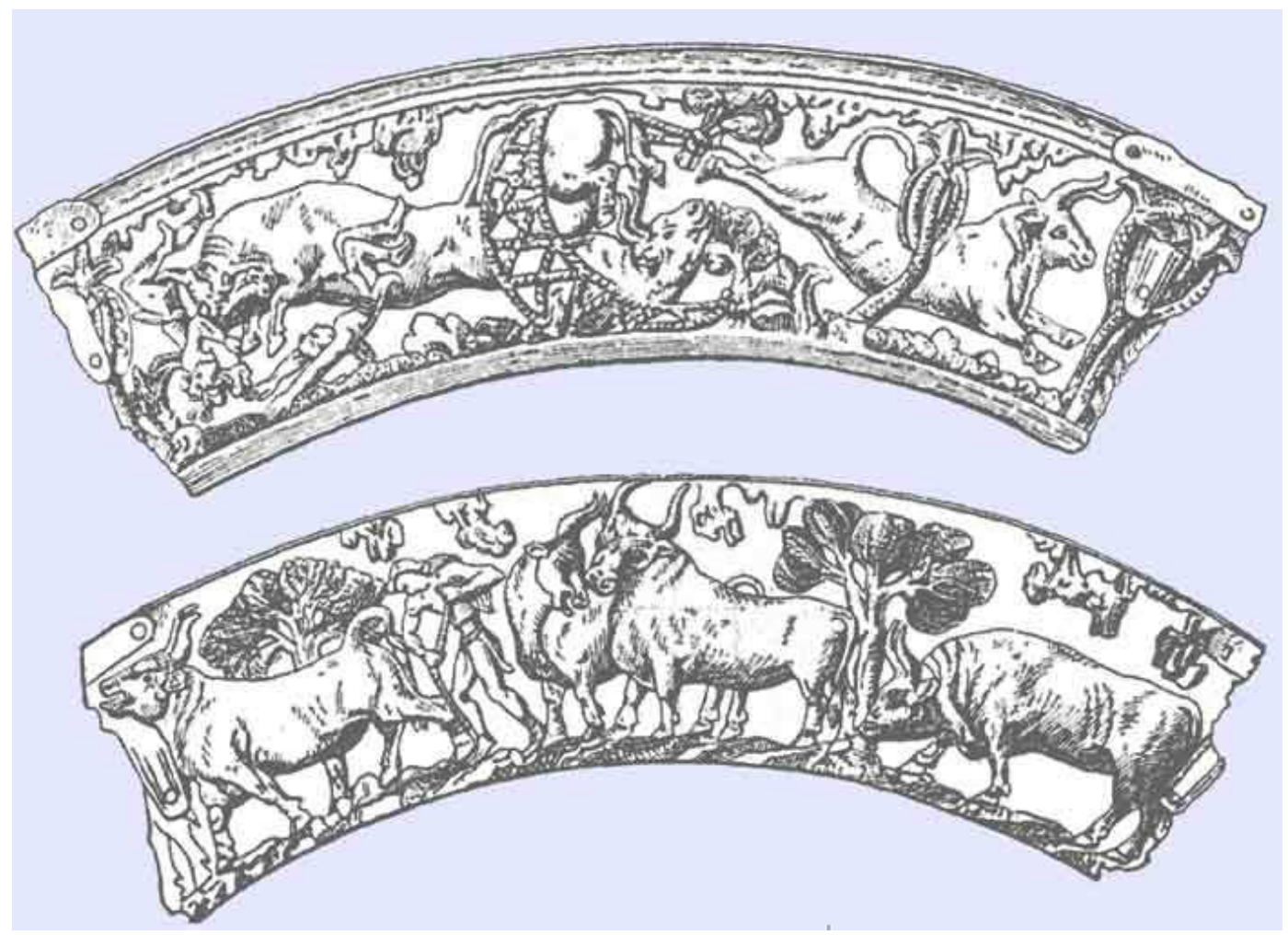

Fig. 5. Desenho do relevo das Canecas Vaphio. Fonte da figura: $<$ http://www.mlahanas.de/Greeks/LX/VaphioCup2.jpg>. Último acesso em 18/09/2008. 


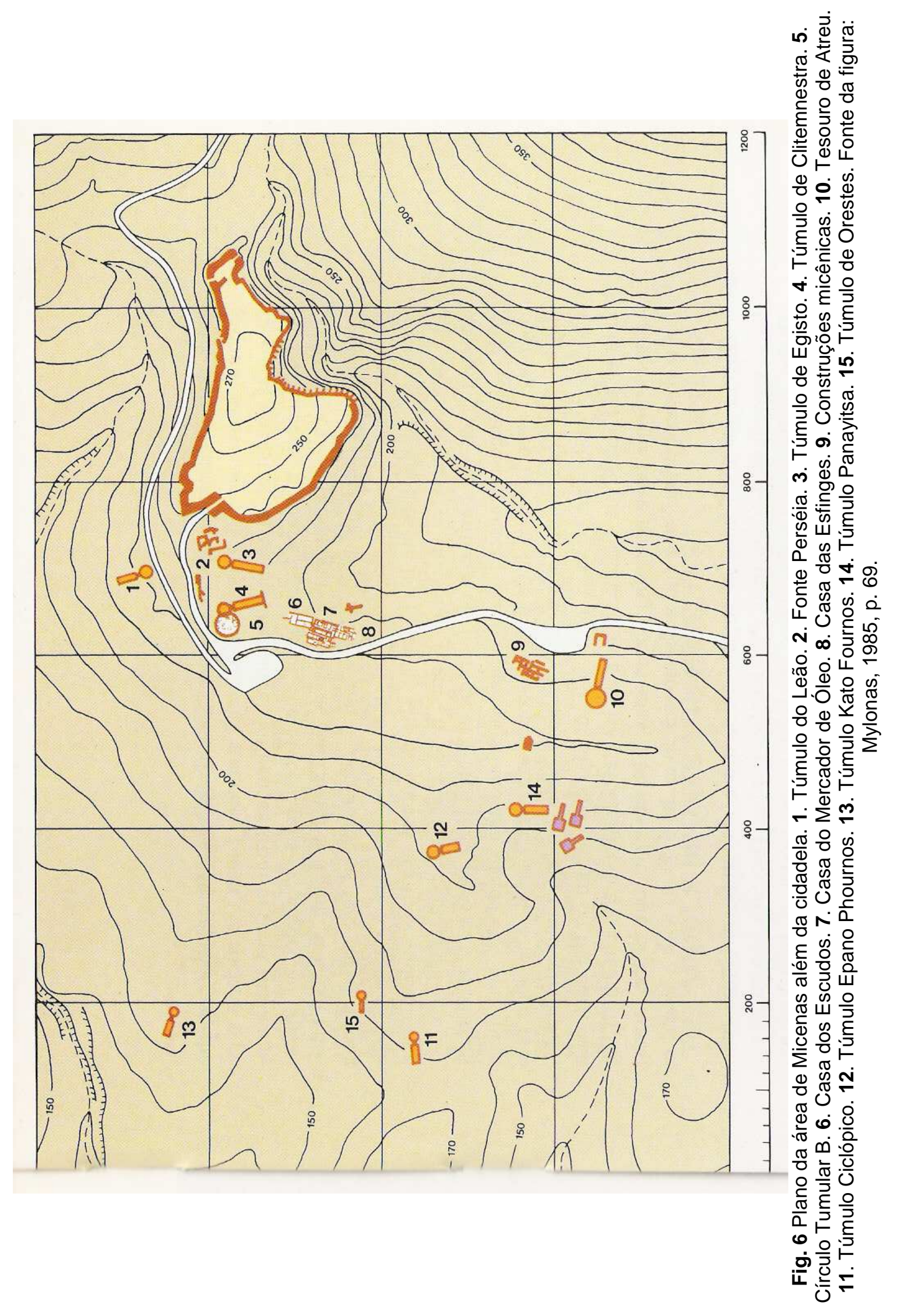




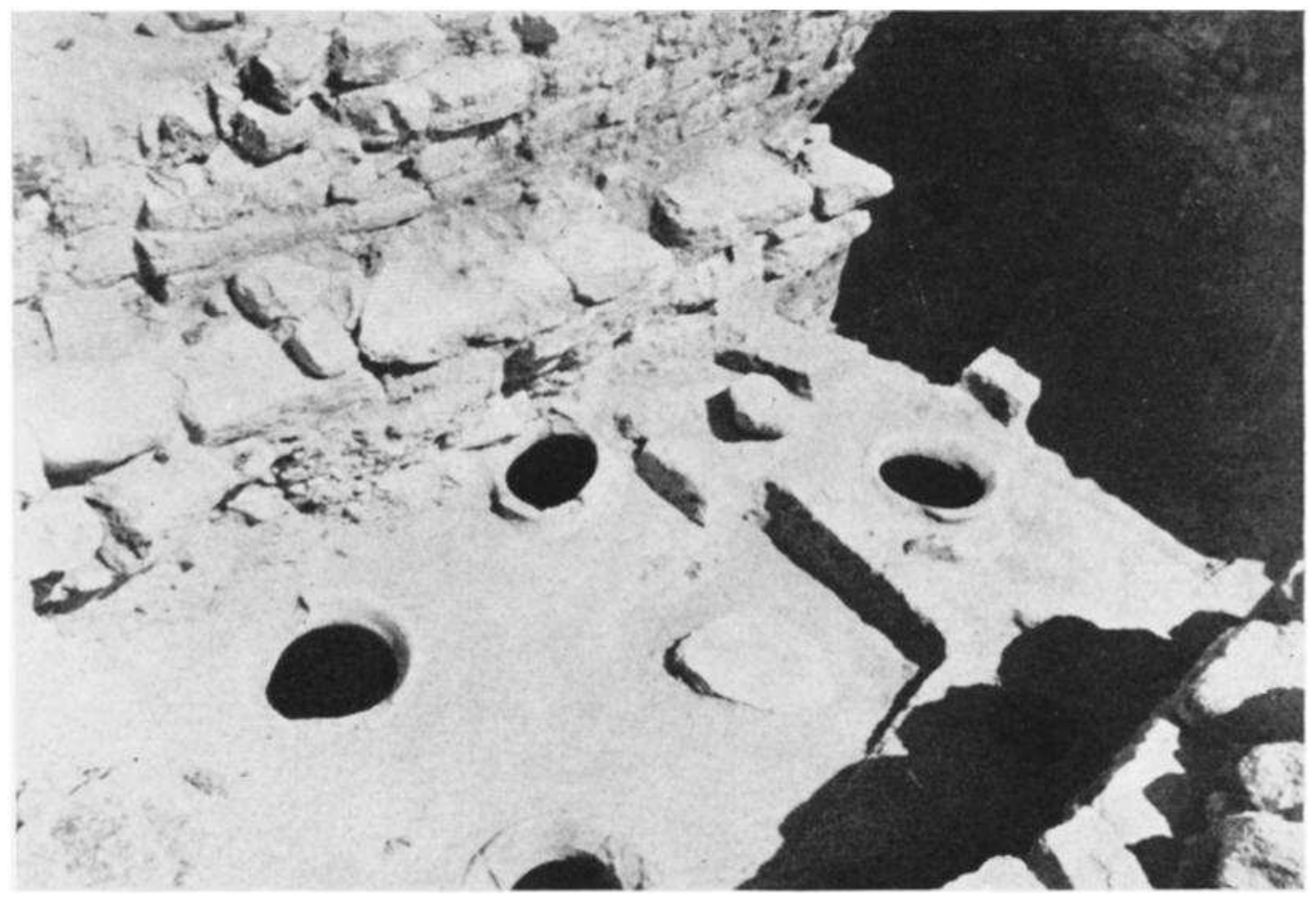

Fig. 7 Píthoi no chão da Casa VII Theta. Tróia VIla. Fonte da figura: Blegen, 1936, p.36.

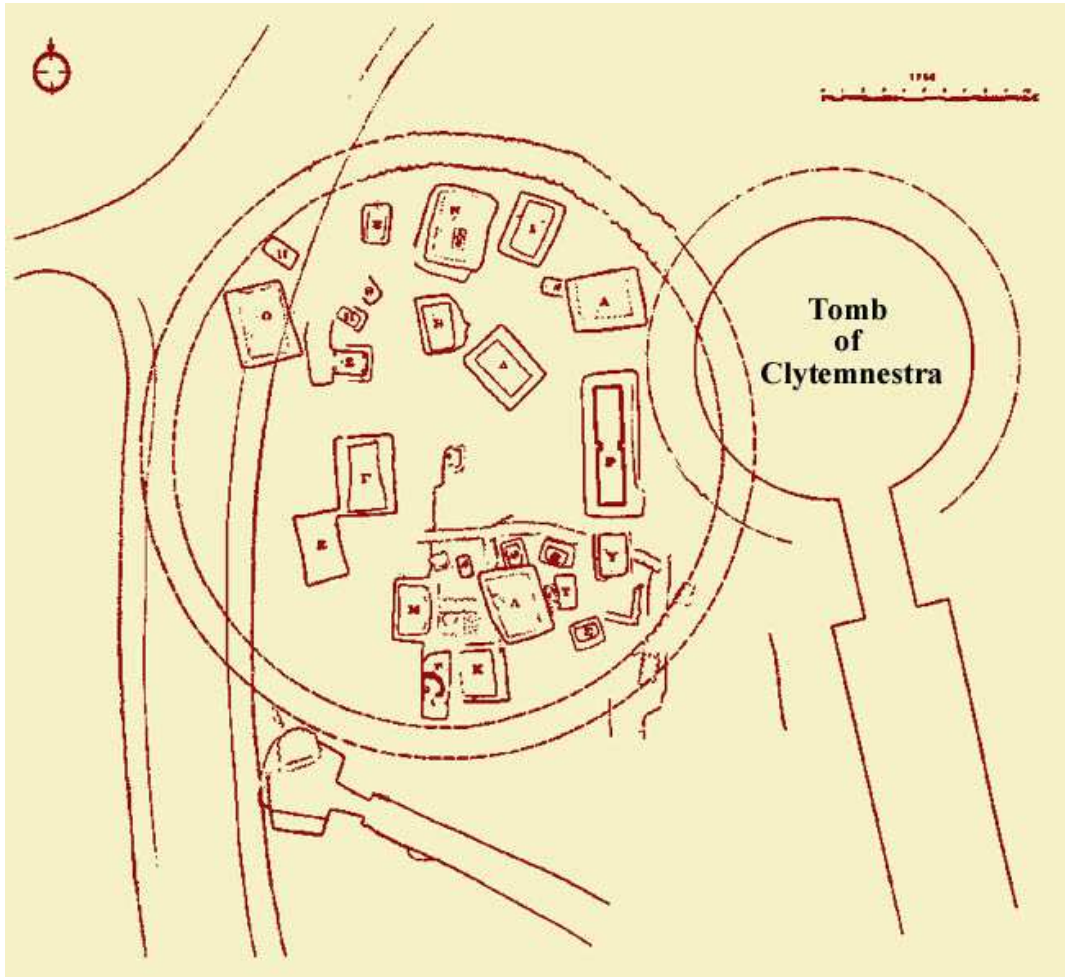

Fig. 8 Plano do Círculo Tumular B. Fonte da figura:

$<$ http://www.odysseyadven tures.ca/articles/mycenae/ mycenae circleb plan.htm $>$. Último acesso em 14/12/2008. 


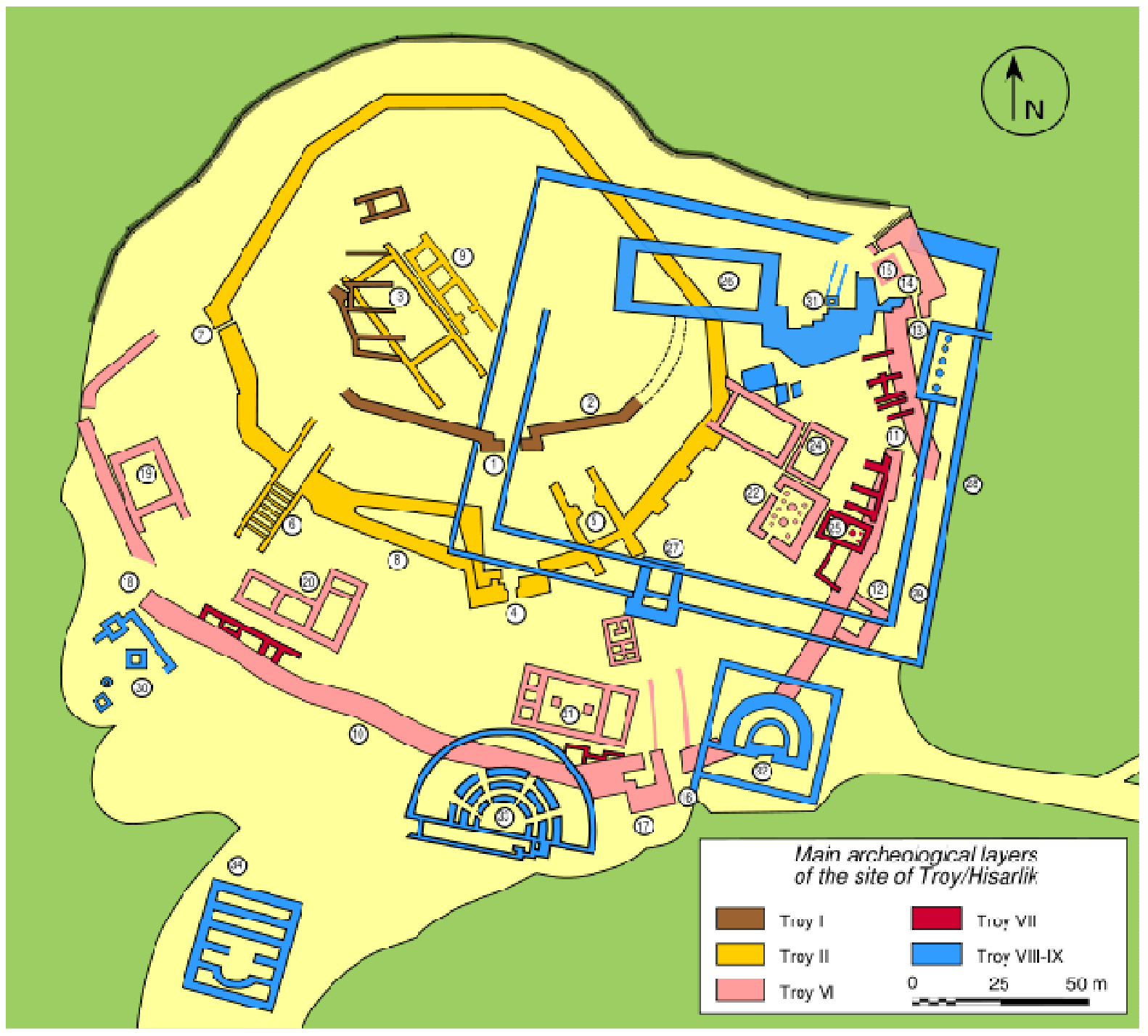

Fig. 9 Plano dos principais estratos da Cidadela ou cidade alta de Tróia. Fonte da figura: $<$ http://en.wikipedia.org/wiki/lmage:Plan Troy-Hisarlik-en.svg>. Último acesso em 13/11/2008. 


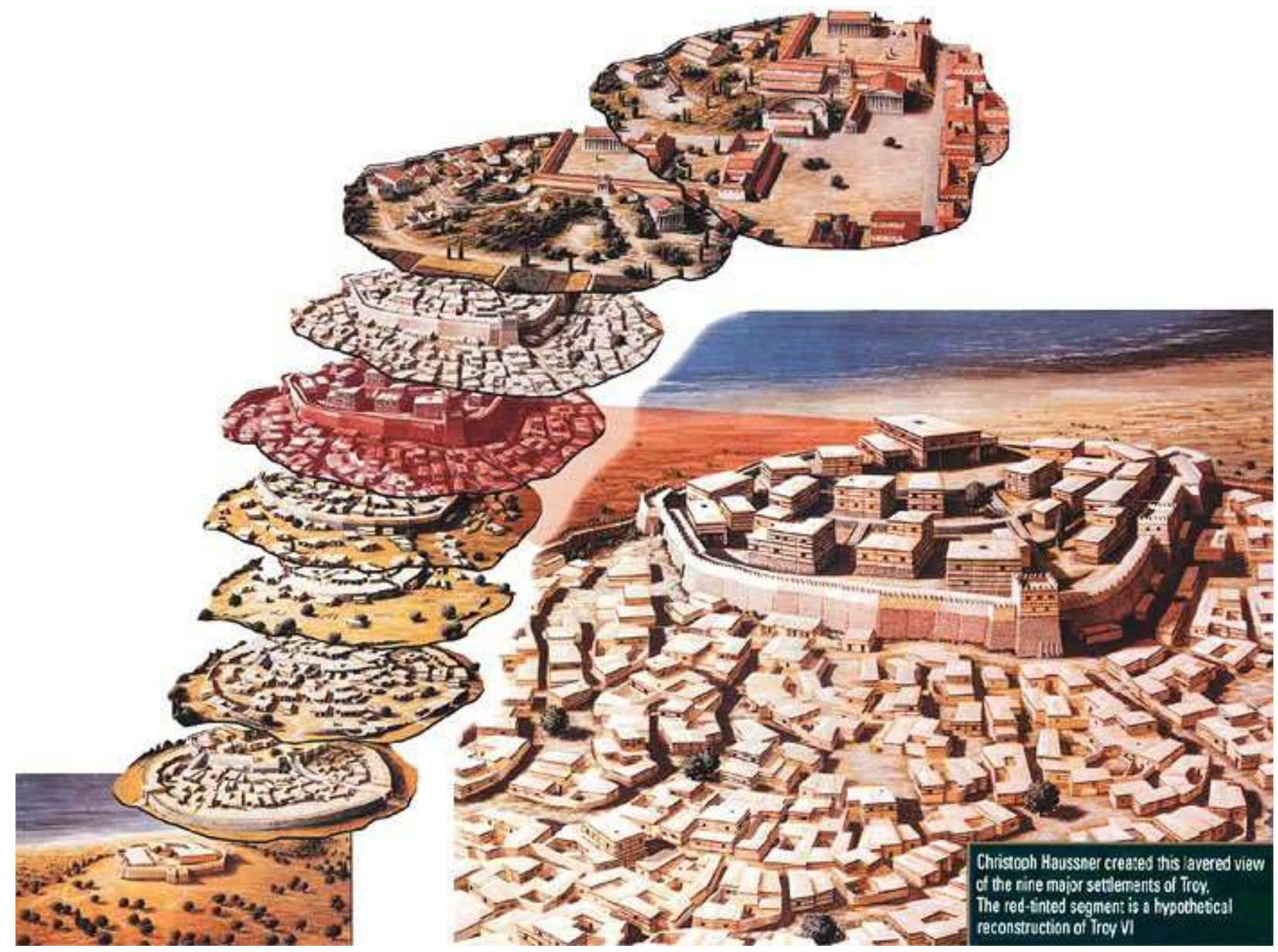

Fig. 10 Reconstrução artística dos estratos de Tróia por Christoph Haussner. Um dos aspectos que chamam bastante a atenção para o trabalho de Korfmann é a reconstrução de várias partes da cidade por C. Haussner baseada nas evidências arqueológicas combinadas com a tradicional técnica de construção local. A introdução de imagens geradas por computador também foi bastante inovadora para esse tipo de pesquisa. O anuário Studia Troica reporta todo trabalho anual e apresenta 17 volumes até 2007. Fonte da Figura:

$<$ http://www.utexas.edu/courses/introtogreece/lect4/img22troylvls.html>. Último acesso em $13 / 11 / 2008$. 
The Historical National Park of Troy

Protected cultural sites

溇 Tumulus

a Historical settlement

(11) Citadel

- Bridge

- Protected areas (1995)

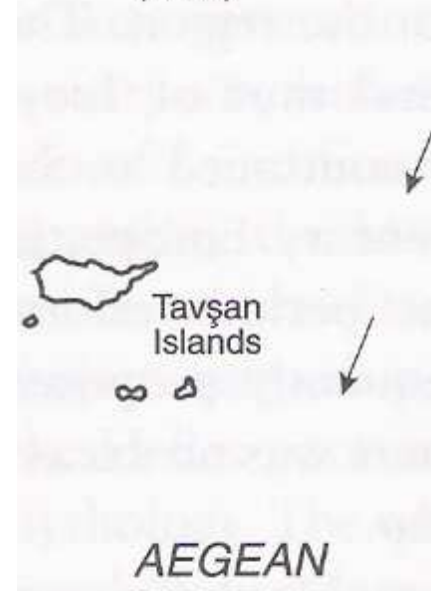

Tenedos/Bozcaada
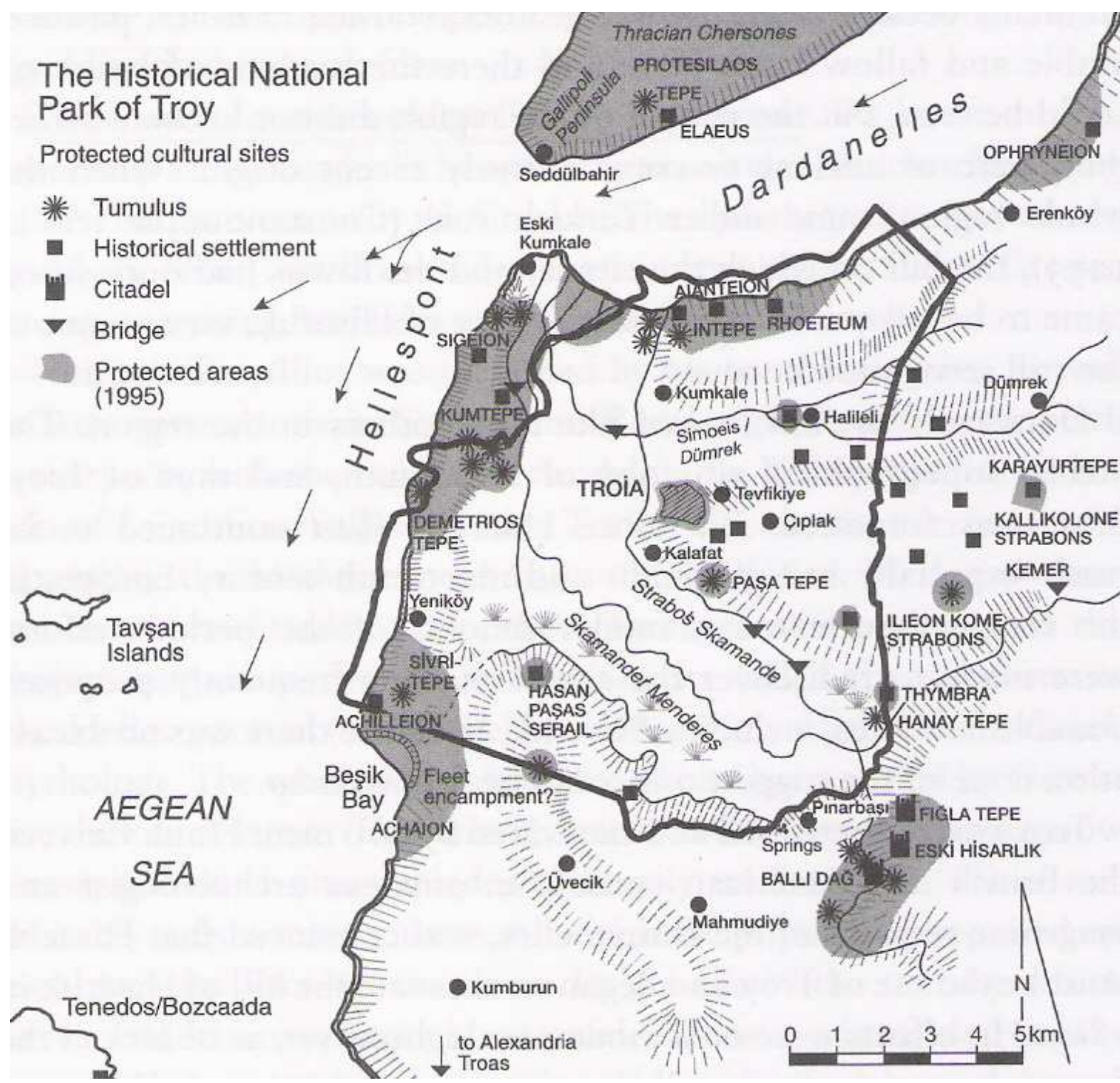

Fig. 11 Tróia e seus arredores atualmente. A linha escura marca os limites do Parque Histórico Nacional de Tróia. Fonte da Figura: Latacz, 2004, p. 6. 


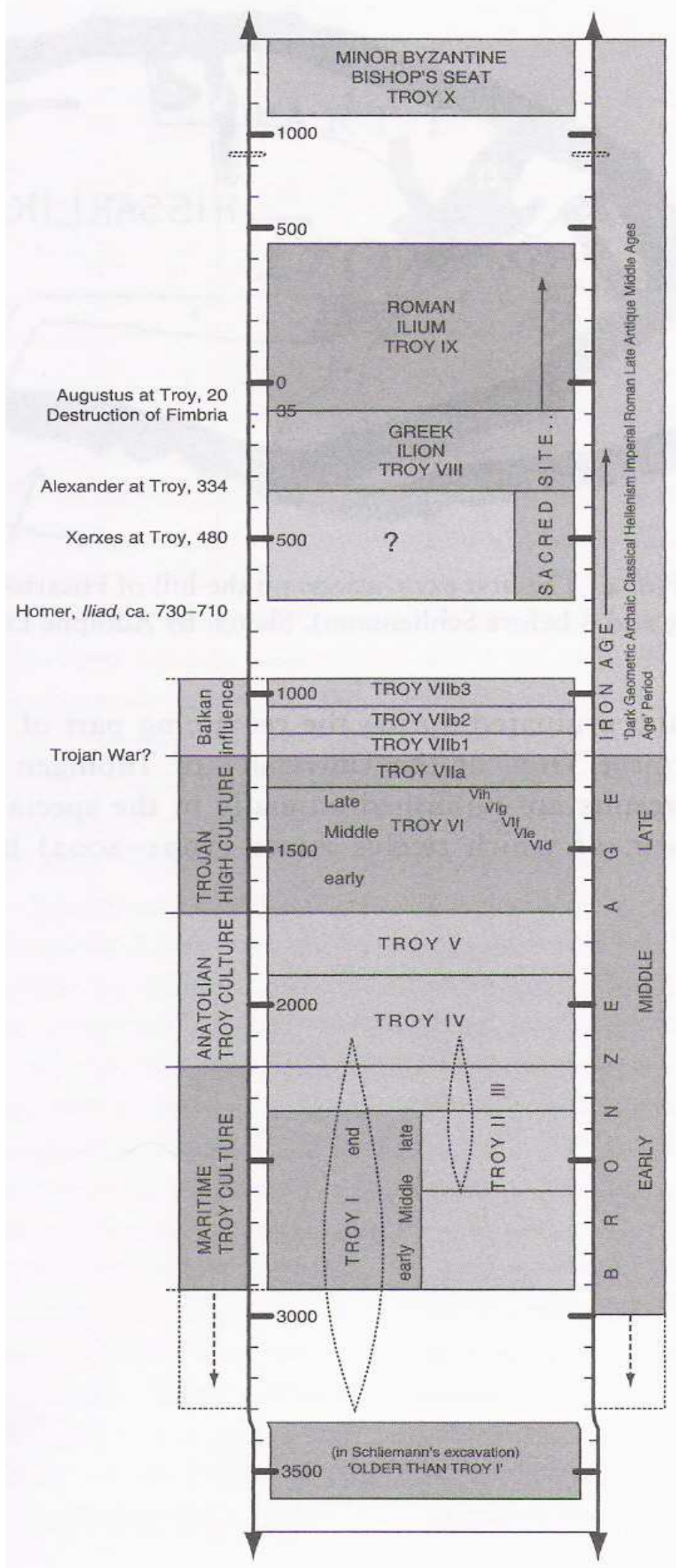

Fig. 12: Níveis de

estabelecimentos sobre Hissarlik estabelecido pela equipe de Korfmann (2000). Fonte da Figura: Latacz, 2004, p. 11. 


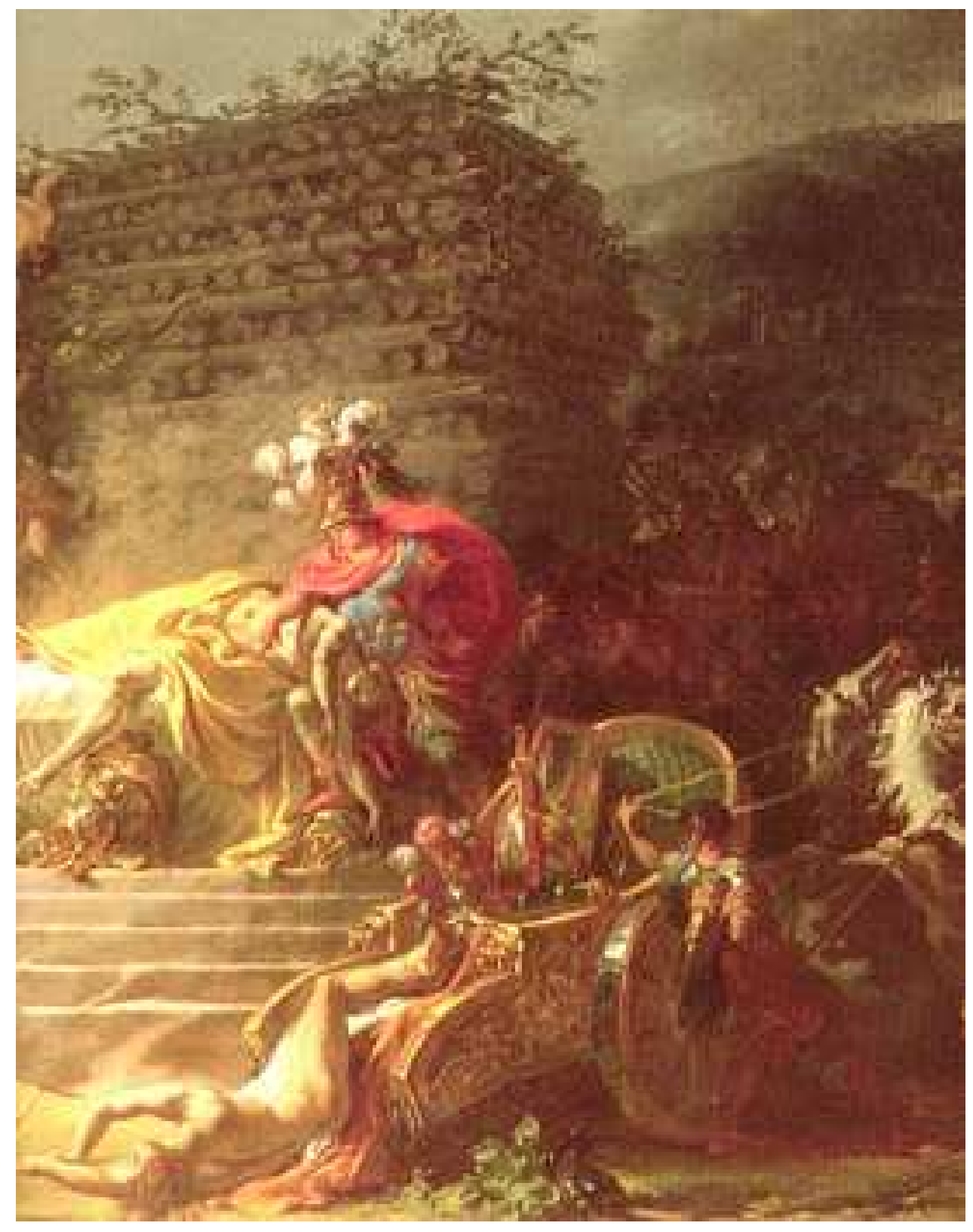

Capítulo 3

Funerais 
Na llíada, o canto XXIII é totalmente dedicado aos funerais em honra do herói Pátroclo. Evidentemente ele não é o único herói a não ter o privilégio do nóstos (retorno) à terra pátria, mas é certamente o único a receber um canto inteiro dedicado às suas honras fúnebres. Do lado troiano, Heitor, morto por Aquiles, que reteve seu corpo até que Príamo fosse à sua tenda reivindicá-lo, também recebe honras fúnebres, mas o poeta não Ihe dedica mais do que trinta versos (XXIV, 775804) no final do último canto do poema. Esses são os dois únicos funerais narrados de maneira mais pormenorizada pelo poeta, embora a expressão "jazer ao pasto de cães e de aves" utilizada na llíada logo no início do primeiro canto (versos 4-5), e que se caracterizará como uma fórmula no decorrer do poema, seja um forte indício da necessidade de se prestar honras aos mortos.

A prática funerária mais freqüente na Ilíada, embora não exclusiva, é a incineração (p. 88, fig. 1); e, quanto maior a posição hierárquica do morto, mais ricas são as honras prestadas. No canto VII por volta do verso 417, por exemplo, após o combate entre as tropas aquéias e troianas, uma trégua é realizada para que ambos os lados da guerra possam prestar as honras fúnebres a seus respectivos mortos; a prática cerimonial para essa massa de guerreiros é bastante reduzida: uns cortam lenha, outros recolhem os mortos; no dia seguinte os mortos são colocados em carros enquanto os vivos choram por eles. Do lado troiano, após o próprio Príamo pedir para que cessem o lamento, em silêncio colocam os mortos na pira fúnebre e os queimam. Ambos os lados queimam seus mortos fora dos limites das habitações, do lado troiano, e fora dos limites do acampamento, do lado aqueu.

O procedimento muda quando se trata dos heróis de primeiro plano. Além de Pátroclo e Heitor, há outras duas menções às honras fúnebres, ambas relativas ao herói Sarpédon (XVI, 453-54 e 667-675). O corpo de Sarpédon seria, segundo as palavras da deusa Hera, mandado de volta à Lícia, "onde a família e os amigos serão os encarregados de lhe dar sepulcro, tumba e estela, o tributo devotado aos 
mortos". ${ }^{1}$ Na passagem 667-675, o deus Apolo lava o corpo de Sarpédon em água corrente, unge-o de ambrosia, reveste-lhe de "roupas imortais" e o envia a Lícia. Essas passagens referentes a Sarpédon são interpretadas como referência à prática da inumação, pois o vocabulário utilizado é diferente do vocabulário empregado para as passagens que expressam a prática da incineração de Pátroclo e Heitor, sendo o verbo ta $r$ x u ein $(X V I, 674)$ mais relaciondo à idéia de depositar na terra (SCHNAPPGOURBEILLON, 1982, p. 79 e nota 3).

Como mencionado, o canto XXIII é inteiramente ocupado pelos funerais de Pátroclo. O caráter singular da cerimônia, as dificuldades de interpretação do texto homérico e a ausência de equivalências na história da Arqueologia são as três causas principais da dificuldade para se compreender o ritual em sua totalidade, apontadas por Schnapp-Gourbeillon (1982, p. 77) em seu artigo sobre o tema.

O episódio dos funerais de Pátroclo, em termos gerais, segue a seguinte ordem de eventos:

1) Preparação: abatem-se bois, ovelhas, cabras e porcos, que em seguida são assados com seu sangue escorrendo ao redor do morto. Banqueteiam-se todos e se vão todos dormir às naus (exceto Aquiles que adormece na praia e recebe Pátroclo em sonho; este lhe pede as honras fúnebres sem as quais não pode adentrar as portas do Hades; Pátroclo também pede que, quando Aquiles morrer, seus ossos sejam depositados junto com os dele). Amanhece e Agamêmnon ordena que busquem lenha; ao fazê-lo, os homens depositam no local que Aquiles designou como sepulcro.

2) Cortejo fúnebre: Aquiles ordena aos mirmidões que se vistam com armas e atrelem os corcéis aos carros para o cortejo fúnebre, no qual os carros vão à frente e as pessoas a pé os seguem; no centro, os parentes e amigos mais próximos portam Pátroclo, coberto de cabelos que eles cortaram e jogaram sobre o cadáver. Aquiles se posiciona à cabeça de Pátroclo.

\footnotetext{
${ }^{1}$ Tradução de Haroldo de Campos (2002).
} 
3) Lamentação: Ao chegar ao local, depositam o corpo e a lenha. Aquiles corta seus próprios cabelos e os coloca nas mãos de Pátroclo. Enquanto todos choram, Aquiles vai pedir a Agamêmnon que ordene cessar o choro coletivo, afastar todos da pira e preparar o banquete.

4) Sacrifícios, oferendas, libações: somente os mais próximos e os chefes aqueus devem permanecer ao lado do morto. Alguns erguem a pira e, em seguida, depõem o corpo sobre ela. Esfolam bois e ovelhas diante da pira; Aquiles extrai a gordura e com ela cobre o cadáver dos pés à cabeça, e amontoa a carne esfolada ao redor do cadáver, junto com ânforas de mel e óleo. O sacrifício então se inicia com quatro cavalos, dois cães e doze jovens troianos imolados e atirados ao fogo, que arderá a noite toda. Aquiles então faz a libação vertendo vinho sobre a terra e invoca Pátroclo.

5) Enterramento da urna cinerária: Ao amanhecer, a pira é apagada com vinho e os ossos de Pátroclo são recolhidos, pois, segundo o poeta, jazendo no centro da pira são claramente distintos dos demais. Os ossos serão então colocados numa urna de ouro e cobertos com gordura, a urna é envolta com linho, a tumba é traçada em torno à pira, onde se colocam pilastras e se enterram os ossos.

6) Jogos fúnebres: Nesse momento, iniciam-se os jogos fúnebres, em que são oferecidos como prêmios lebes e trípodes, cavalos, mulas e bois, e moças. $O$ primeiro jogo é a corrida de carros seguido de pugilato, luta 'greco-romana', corrida, combate armado, disco, arco e lança.

Os funerais de Heitor (XXIV, 775-804), de maneira geral, seguem procedimentos muitos semelhantes aos funerais de Pátroclo: conseguir uma grande quantidade de madeira para a pira, ao qual se seguem as libações com vinho; as cinzas são recolhidas e colocadas numa urna de ouro recoberta por um tecido púrpura, que em seguida é deposta numa fossa coberta de terra e sobre a qual jazerá um sema de pedra. O banquete fúnebre fecha a cerimônia do lado troiano, ao 
contrário do procedimento dos aqueus que se banqueteiam antes, sendo a cerimônia seguida pelos jogos.

O sacrifício de doze jovens troianos, abatidos pelas mãos do próprio Aquiles durante os funerais de Pátroclo, talvez seja a prática mais embaraçosa no episódio, qualificada pelo próprio poeta como kaka|eł ga , "maldosas ações” (XXIII, 176).

As escavações de Vassos Karageorghis em Salamina de Chipre, realizadas nas décadas de 1950 e 1960, revelaram uma necróple datada dos séculos VIII e VII a.C., cujas práticas talvez encontrem paralelos nas cenas homéricas de funerais. No interior do Túmulo 1, em um recipiente em bronze, foram depositadas as cinzas do morto envolvidas em um tecido como indicado nas passagens XXIII, 243 e XIV,795; o mesmo túmulo continha vasos de óleo e, no exterior, dois cavalos foram encontrados no dromos ritualmente abatidos (Ilíada, XXIII, 170-2), acompanhados dos restos de madeira de um carro (KARAGEORGHIS, 1969, p. 25-8). O sacrifício de cães é igualmente atestado em Argos, por exemplo, e em Esparta, mas para períodos mais recentes. Quanto ao sacrifício humano, as fontes divergem; SchnappGourbeillon (1982, p. 78) diz que o sacrifício humano realizado por Aquiles é um exagero poético, não refletindo uma prática real. Mas o sacrifício humano é atestado arqueologicamente pelos achados do Túmulo 2 (c.700 a.C.) de Salamina de Chipre, cuja prática funerária envolveu dois ou mais sacrifícios humanos, bem como sacrifício de gado (KARAGEORGHIS, 1969, p. 30-31).

No final do século XIX, quando as publicações de Schliemann e de Tsountas associavam a sociedade micênica com a sociedade presente nos poemas homéricos, a incongruência entre os costumes funerários daquela civilização, em que os grandes túmulos eram repositórios da inumação dos mortos, e aqueles descritos em Homero, em que a incineração é a prática dominante, não deixou de colocar a comunidade de estudiosos diante de uma situação embaraçosa. Como explicar tal incongruência?

Com o avanço das pesquisas arqueológicas e o aumento do número de sítios escavados, notou-se que a inumação dos mortos, característica dominante na época 
micênica, ${ }^{2}$ foi se substituindo pela prática da incineração. Essa nova prática se mostrou não ser tão nova assim, já que na Tessália ela fora praticada esporadicamente em períodos precedentes (HÄGG, 1987, p. 207). A prática desse novo procedimento de maneira mais ampla no Egeu durante a passagem da Idade do Bronze para a Idade do Ferro é um fenômeno cuja explicação residia na chegada de um novo povo, os dórios, mas essa explicação aos poucos tem sido abandonada, sendo atualmente encarada como uma prática que se espalhou do Oriente sem necessariamente ser acompanhada de um movimento populacional que implicasse na invasão do território grego por um outro povo (lbidem).

Embora a prática da incineração do morto tenha passado a ser dominante durante a Idade do Ferro na Hélade Continental, tanto em Atenas, como em Lefkandi, ela é quase exclusiva para os adultos, e as crianças continuaram a ser inumadas nos Túmulos em Cista e também em jarros (SARIAN, 1989, p. 588). Na Argólida, a inumação continuou a ser praticada quase que exclusivamente através do período entre 1050 a 800 a.C. enquanto a incineração tinha se tornado predominante em outras regiões (DESBOROUGH, 1964, p. 71; SNODGRASS, 1971, p. 191; e HÄGG, 1987, p. 207).

Se a poesia homérica se propunha a retratar o Período Micênico, ela falhava quanto às suas práticas mortuárias. Embora não se possa dizer que a inumação era totalmente estranha aos poemas, a incineração de dois grandes heróis dos poemas homéricos reflete uma prática corrente durante a Idade do Ferro, contemporânea à data proposta para a composição dos poemas, mais precisamente o século VIII a.C.

Três tipos de evidências sugerem uma necessidade de se estabelecer conexões com os reis do Período Micênico: o aumento repentino do culto heróico em várias regiões, demonstrado pela nova prática de deixar oferendas votivas em túmulos micênicos; as reminiscências da era heróica na arte figurativa, às vezes referindo-se a um episódio específico ou apresentando detalhes emprestados pelo tema heróico; e a circulação da poesia épica. Os reis micênicos se tornaram objeto de certo interesse por parte dos governantes do Período Geométrico e, em conseqüência disso, tornaram-se os heróis da poesia épica.

\footnotetext{
${ }^{2}$ Desborough (1964, p. 32) afirma que o "túmulo em câmara é característico de cada um dos distritos habitado pelos micênios' ("the chamber tomb is characteristic of every district inhabited by the Mycenaeans." ).
} 


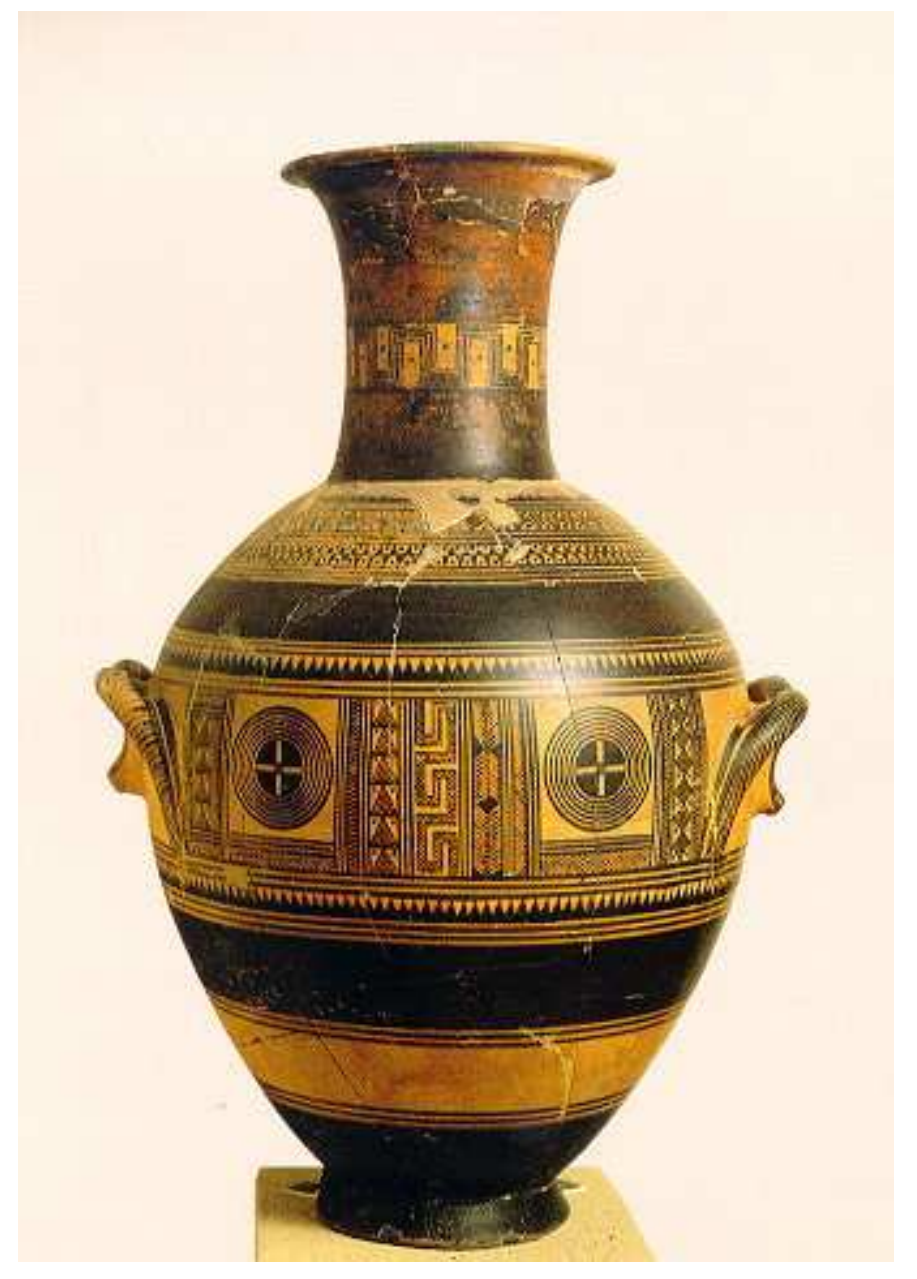

Fig. 1 Ânfora cinerária. (c. 860-840

a.C.). Museu Arqueológico do Cerâmico. Fonte da Figura:

$<$ http://teachers.sduhsd.k12.ca.us/ltr upe/art\%20history\%20web/final/chap 5 Greece/CineraryAmphora.jpg >. Último acesso em 29/11/2008.

\subsection{Culto Tumular X Culto Heróico ou Culto Heróico $\cap$ Culto Tumular?³}

Quando Blegen, em 1937, publicou os resultados das escavações sob sua direção nos túmulos do Heládico Recente em Prosymna, revelou-se que quase um terço dos Túmulos em Câmara e thóloi do Período Micênico continham cerâmica e objetos de bronze datados do Geométrico Recente e do Período Arcaico. Esse material foi interpretado por ele como oferendas votivas a ancestrais heróicos, possivelmente deixadas por descendentes das famílias micênicas que construíram esses túmulos (BLEGEN, 1937).

A descoberta de deposições de oferendas durante o Período Geométrico no interior de túmulos utilizados no Período Micênico juntou-se à descoberta de locais,

\footnotetext{
${ }^{3}$ O símbolo “ $\cap$ ” é um símbolo matemático que significa ‘intersecção’.
} 
muitas vezes distantes dos Túmulos em Câmara ou das thóloi, consagrados à deposição de oferendas em honra a um herói, denominados herôa (singular herôon): em Micenas, em honra a Agamêmnon; em Ítaca, atribuído a Odisseu; e um terceiro em Esparta, atribuído a Menelau.

Ambas as práticas, ou seja, a deposição de oferendas no interior de um túmulo do Período Micênico e a deposição das mesmas em lugares que não tinham uma relação com qualquer túmulo, foram então denominadas como "culto heróico", e a evidência arqueológica para essa prática foi datada desde o Período Geométrico Recente (c. 750 a.C.) até o Arcaico (c. 650 a.C.). A prática, em geral, é caracterizada pela ação de depositar oferendas, principalmente cerâmica, à intenção de um morto de uma época 'heróica'; quando a oferenda é entregue em um túmulo, ela, em geral, não apresenta nenhum destinatário nomeado; mas quando essa oferenda é depositada num santuário e não num túmulo, o destinatário é nomeado. Pelo fato de essa prática ter sido difundida durante o século VIII a.C., ela é freqüentemente associada à circulação da poesia homérica. Como conseqüência dessa associação, Coldstream (1976), que coletou os depósitos votivos em túmulos micênicos por toda a Grécia, definiu o período de 750-650 a.C. como "Idade de Homero".

Mas alguns santuários, como o de Kato Syme em Creta e de Kalapodi na Fócida, parecem ter recebido oferendas sem uma interrupção cronológica reconhecível desde a Idade do Bronze até o fim da Idade do Ferro Antiga e nas proximidades de Cnossos há evidências de reutilização de túmulos e lárnakes da Idade do Bronze. Alguns túmulos do Heládico Tardio III C são ricos em keimelia, relíquias de períodos anteriores, assim como a maior parte dos túmulos do ProtoGeométrico como, por exemplo, a Tumba de Lefkandi. A partir da verificação dessa continuidade, a "Idade de Homero" de Coldstream então teria de ser estendida à Idade do Ferro Antiga.

Snodgrass (2000 [1971]), Whitley (1991) e I. Morris (1991) têm discutido o fenômeno culto tumular/culto heróico em anos recentes, diminuindo a ênfase na influência de Homero nessas práticas e apelando mais a fatores históricos e sociais. Tanto Snodgrass quanto Morris propõem que o culto heróico não era uma

\footnotetext{
${ }^{4}$ Para uma revisão bibliográfica acerca do Culto Heróico e Culto Tumular, sugiro a leitura da dissertação de mestrado de Souza (2005).
} 
característica da prática cultual grega instigada pela épica, mas uma transformação do culto aos ancestrais no interior do contexto social da cidade-estado, pois a veneração de ancestrais já era amplamente praticada no mundo grego ao longo da Idade do Ferro:

Na Academia de Atenas, o culto de Academos, seu fundador, se iniciou no Geométrico Antigo I (900-875); Ulisses é honrado em Ítaca, na gruta de Polis, onde são depositadas trípodes em torno de 800 a.C; a partir de 700 a.C., celebra-se um culto em Micenas em honra de Agamêmnon, e em Esparta em honra de Menelau e de Helena. (SARIAN, 1989, p. 588) (Tradução própria)

Tal transformação teria um reflexo possível na épica, que teria passado de narrativas sobre ancestrais para a celebração épica de heróis. Dessa forma, a emergência da épica no século VIII a.C. aconteceria paralelamente à emergência da polis e do pan-helenismo. Se o culto heróico teve precedentes no culto a um ancestral existente desde o século $X$ a.C., esse culto extravasou os limites espaciais do túmulo desse ancestral para ser cultuado como um personagem ligado à formação da cidade ou um herói, passando do culto funerário ao culto heróico.

Alcock (1991, p. 448) define o culto funerário como um ritual cujo objetivo é "estabelecer uma ligação entre a sociedade que o pratica e as poderosas entidades associadas aos túmulos antigos. A figura evocada deve ter sido um herói ou um ancestral (duas categorias que se sobrepõem com freqüência)". A autora também chama a atenção sobre a dificuldade em distinguir qual desses papéis o morto assumia somente a partir da evidência material. A distinção entre culto funerário e culto heróico estaria apenas na distinção do papel que o morto assumiria. Como o culto aos ancestrais não desaparece com o surgimento do culto heróico ou com a emergência da polis, Antonnacio (1994) lança mão da hipótese de que ambos expressam maneiras distintas de articulação com o passado.

A omissão ou não de Homero em relação ao culto heróico também é algo bastante discutido (PRICE, 1973). O tratamento de Erecteu na Ilíada e o apreço pela topografia dos túmulos seriam elementos que comprovariam o conhecimento do

\footnotetext{
5 “'A l'Académie d'Athènes, le culte d'Académos, héros fondateur de la ville, commence dès le Géométrique Ancien I (900-875). Ulisse est honoré à Ithaque, dans la grotte de Polis, où sont déposés des trépieds aux environs de 800. A partir de 700, on célèbre um culte à Mycènes em l'honneur d'Agamemnon, et à Sparte à l'intention de Ménélas et d'Hélène.
} 
culto heróico em Homero. De qualquer maneira, se existir ou não uma continuidade entre a Idade do Bronze e a Idade do Ferro no que diz respeito ao culto aos ancestrais ou ao culto heróico, o século VIII a.C. reflete ou a necessidade de manter uma conexão com uma idade percebida como heróica; ou, se não houver essa continuidade, o século VIII a.C. reflete uma necessidade emergente de se buscar essa conexão com tal passado. E a épica e o culto heróico, ou até mesmo o culto de personagens épicos (COLDSTREAM, 1977, p. 346-8), seriam, por sua vez, instrumentos a favor dessa conexão, independentemente da existência ou não de uma continuidade.

\subsection{Reminiscências da Era Heróica na Arte Figurativa do Século VIII a.C.: pintores ilustrando Homero?}

A partir de cerca de 760 a.C., data que marca o início do Geométrico Recente que vai até 700 a.C., é que as cenas com figuras humanas voltam a ser representadas em cerâmica depois de quatro séculos durante os quais, com raríssimas exceções, apenas ocorrem motivos geométricos abstratos. Qualquer que tenha sido a razão ou a origem da reintrodução da arte figurativa, ela pressupunha, por um lado, a capacidade e a possibilidade do artista de representar cenas que pudessem ser compreendidas por seus contemporâneos; e, em contrapartida, a demanda dos mesmos e sua capacidade de compreendê-la. Considera-se responsável por essa reintrodução da arte figurativa na cerâmica o famoso Pintor do Dípilon, que teria comandado um ateliê em Atenas entre os anos de 760-750 a.C. (AHLBERG-CORNELL, 1992, p. 19) e que foi nomeado a partir do cemitério do Dípilon em Atenas, onde seus grandes vasos serviam como marcos funerários.

Coldstream (1977, p. 352-6) acredita que vários elementos na arte do Período Geométrico pertençam à esfera mítica/épica. Outra sugestão é de que as cenas figurativas da arte desse período apresentam uma 'tonalidade' épica em termos mais gerais, ou seja, que os artistas conscientemente transferiram as figurações ao nível épico, embora não tenham como objetivo um personagem ou episódios específicos. 
Isso se aplicaria às cenas de funerais e combate encontradas na cerâmica do século VIII a.C (fig. 3 e fig. 4).

A arte figurativa começaria a adquirir essa tonalidade épica no final do século VIII a.C., e seria fruto do interesse nesse passado heróico, já manifestado nos costumes funerários. A relação entre a épica e a arte figurativa desse período freqüentemente tem sido colocada como uma relação de causa e efeito: a causa seria os poemas homéricos e o efeito seria a figuração de elementos dessas narrativas nas artes visuais. Ahlberg-Cornell (1992, p. 181) acredita que a representação de episódios épicos se inicia exatamente com uma cratera do Pintor do Dípilon, datada de c.760-750 a.C, onde figuram os gêmeos siameses AktorioneMolione (Ibidem, fig. 34, $\left.\mathrm{n}^{\circ} 1\right)^{6}$ e, assim, ele tenha sido o primeiro a avançar a figuração para a esfera épica. Ela também acredita que a llíada foi a primeira composição épica a inspirar os artistas do Geométrico, pois um pintor de c. 750-735 a.C. teria se inspirado num trecho do canto XXIII como fonte para a decoração de uma cratera (Ibidem, fig. 36-38) ${ }^{7}$ retratando Aktorione-Molione no funeral do rei Amarinqueu de Buprásion, ocasião em que os gêmeos siameses derrotam Nestor numa corrida de carros. Outro pintor ainda, em c. 735-720 a.C., teria representado um episódio do canto XI onde os gêmeos são derrotados por Nestor, mas resgatados por Poseidon (Ibidem, fig. 39, n-4). Para a autora, essas representações estariam de acordo com a tradição literária, o que prova que os pintores estavam familiarizados com a narrativa épica.

Ahlberg-Cornell, em sua tabela 70 (lbidem, p. 214-215), mostra que a llíada teria inspirado 12 cenas figurativas em vasos antes de 650 a.C., e sua tabela 52 (Ibidem, p. 192) mostra que, através dos períodos Geométrico e Arcaico, o mesmo poema inspirou mais cenas do que qualquer outro (18 no total).

Esse posicionamento em relação à arte figurativa do século VIII se contrapõe àquele defendido por Snodgrass (2004 [1998], passim): poeta e pintor são tipos independentes de artistas com diferentes fontes, interesses e técnicas. Evidentemente, a tradição oral que culminou com os poemas homéricos no século

\footnotetext{
${ }^{6}$ Esta cratera fragmentária mostra apenas as quatro pernas representadas juntas voltadas para o mesmo lado. A identificação é razoável, mas não é certa. Ela se encontra no Museu do Louvre, Paris, número de inventário A517.

${ }^{7}$ New York, Metropolitan Museum, Número de inventário 14.130.15.
} 
VIII a.C. já era familiar aos artistas do Geométrico e a seus clientes, mas o que prova realmente que a arte figurativa, ao invés de ilustrar a narrativa épica, não seja o produto de um mesmo meio cultural que também forneceu material para a poesia épica? As cenas pintadas na cerâmica do século VIII a.C. não devem ser subjugadas à poesia épica, mas devem ser vistas como um outro meio através do qual se representa a ação heróica ou a atitude em relação ao morto por parte de quem pratica as honras fúnebres dignas de um herói.

Mesmo que as cenas representadas nos vasos do Período Geométrico Recente apresentem um conteúdo heróico ou mitológico, elas não fornecem provas suficientes de que os artistas se referissem necessariamente à poesia homérica.

Da mesma forma, as inscrições em versos sobre a cerâmica do final do século VIII a.C. mostram certa familiaridade com a forma métrica da épica. Mas seriam essas inscrições citações de Homero? Em 1954, foi encontrada em um túmulo no sítio de Pithekoussai, na ilha de Ísquia, na Itália (a mais antiga colônia grega a oeste) uma kotile (fig. 2), que se acredita ter sido manufaturada na ilha de Rodes, datada de cerca de 720 a.C., com uma inscrição que diz: "Eu sou a taça de Nestor, boa para beber. Quem quer que beba de mim, imediatamente será tomado do desejo de Afrodite bem-coroada". Embora essa inscrição seja considerada uma influência direta da épica homérica, ela não é uma citação direta da llíada ou da Odisséia (SNODGRASS, 1979, p. 124).

Transcrição da inscrição:

NELTOPO $:$ :...:ЕYПOTON:ПOTEPION

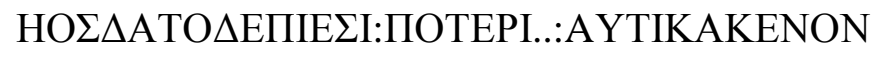

HIMEPO $\Sigma H A I P E \Sigma E I: K A \Lambda \Lambda I \Sigma T E \Phi A N O: A Ф P O \Delta I T E \Sigma$

Nestoroj ... eupoton pothrion:

Dj d"ahtoute piths i pothrion autika khan

Imeroj aithsei kall istefanou Afrodithj. 

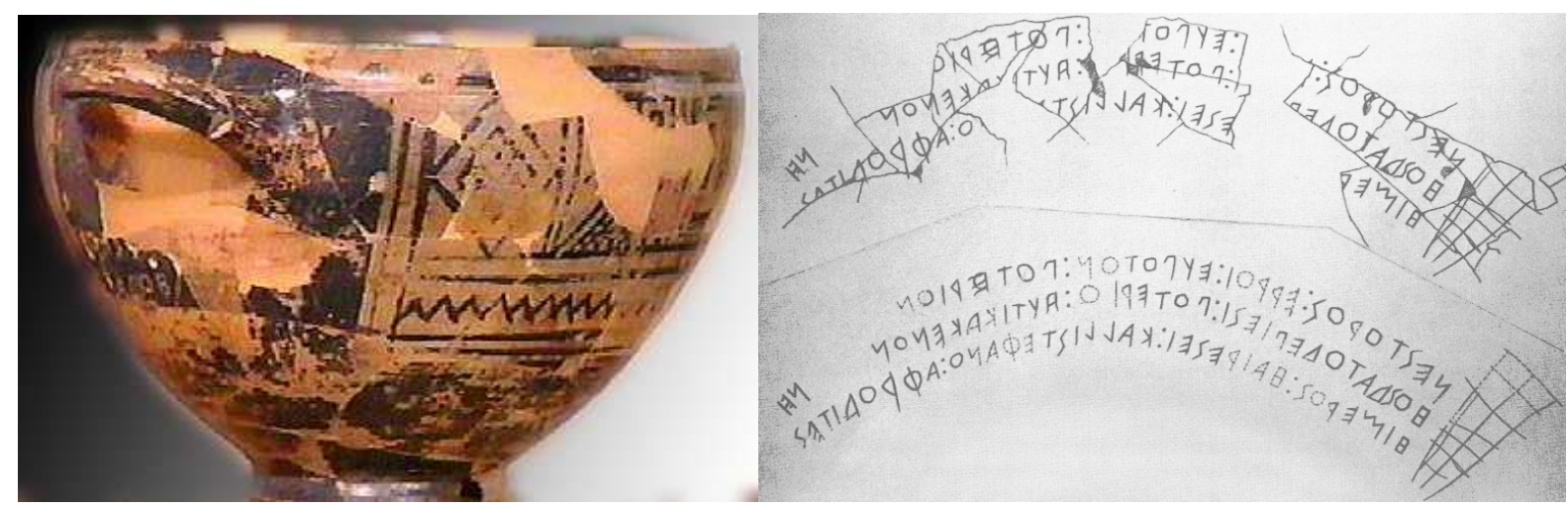

Fig. 2 'Taça de Nestor'. Kotile datada de c. 720 a.C. Proveniente do túmulo 168 da Necrópole do Valle de S. Montano. Museu de Villa Arbusto, Lacco Ameno, Ísquia.

Fonte da figura (kotile): http://upload.wikimedia.org/wikipedia/commons/a/ae/Coppa di Nestore.png em 29/11/2008. Fonte da figura (inscrição):

http://upload.wikimedia.org/wikipedia/commons/3/3c/Nestor Cup Cumae.jpg em 29/11/2008.

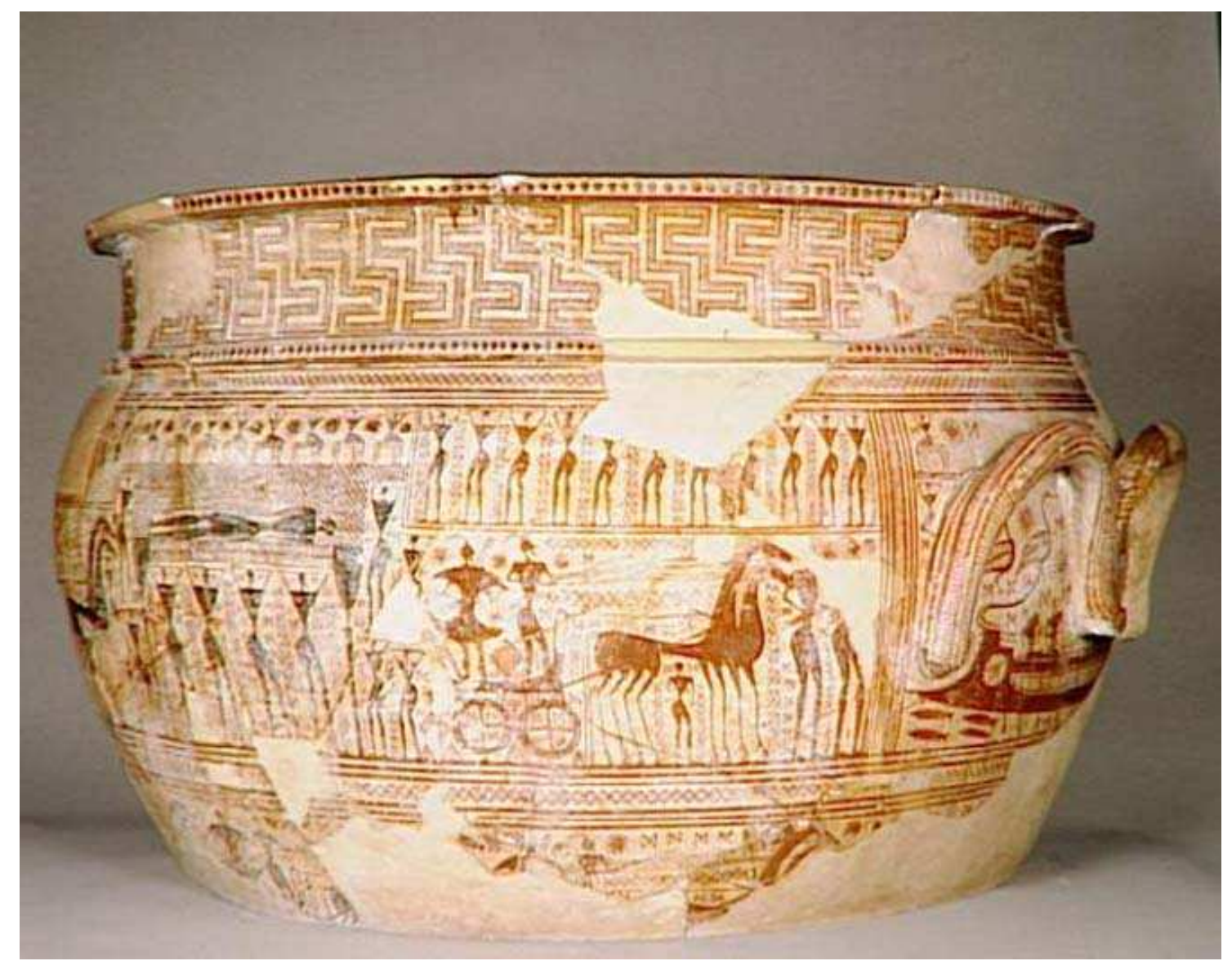

Fig. 3 Cratera Fragmentária atribuída ao Mestre do Dípilon utilizada como marcador tumular. (c. 750 a.C.). O painel entre as alças mostra uma cena de próthesis em que o morto é velado em sua mortalha e chorado pela comunidade ou pessoas próximas. Guerreiros armados a pé ou em carros acompanham o cortejo fúnebre (ekphorá). Altura: $58 \mathrm{~cm}$ (fragmento). Museu do Louvre, Paris. Número de Inventário: A 517. Fonte da Figura:

$<$ http://www.louvre.fr/llv/oeuvres/detail notice.jsp?CONTENT\%3C\%3Ecnt id=10134198673225197\& CURRENT LLV NOTICE\%3C\%3Ecnt id=10134198673225197\&FOLDER\%3C\%3Efolder id=985272 $3696500782 \& b m L o c a l e=e n>$. Último acesso em 29/11/2008. 


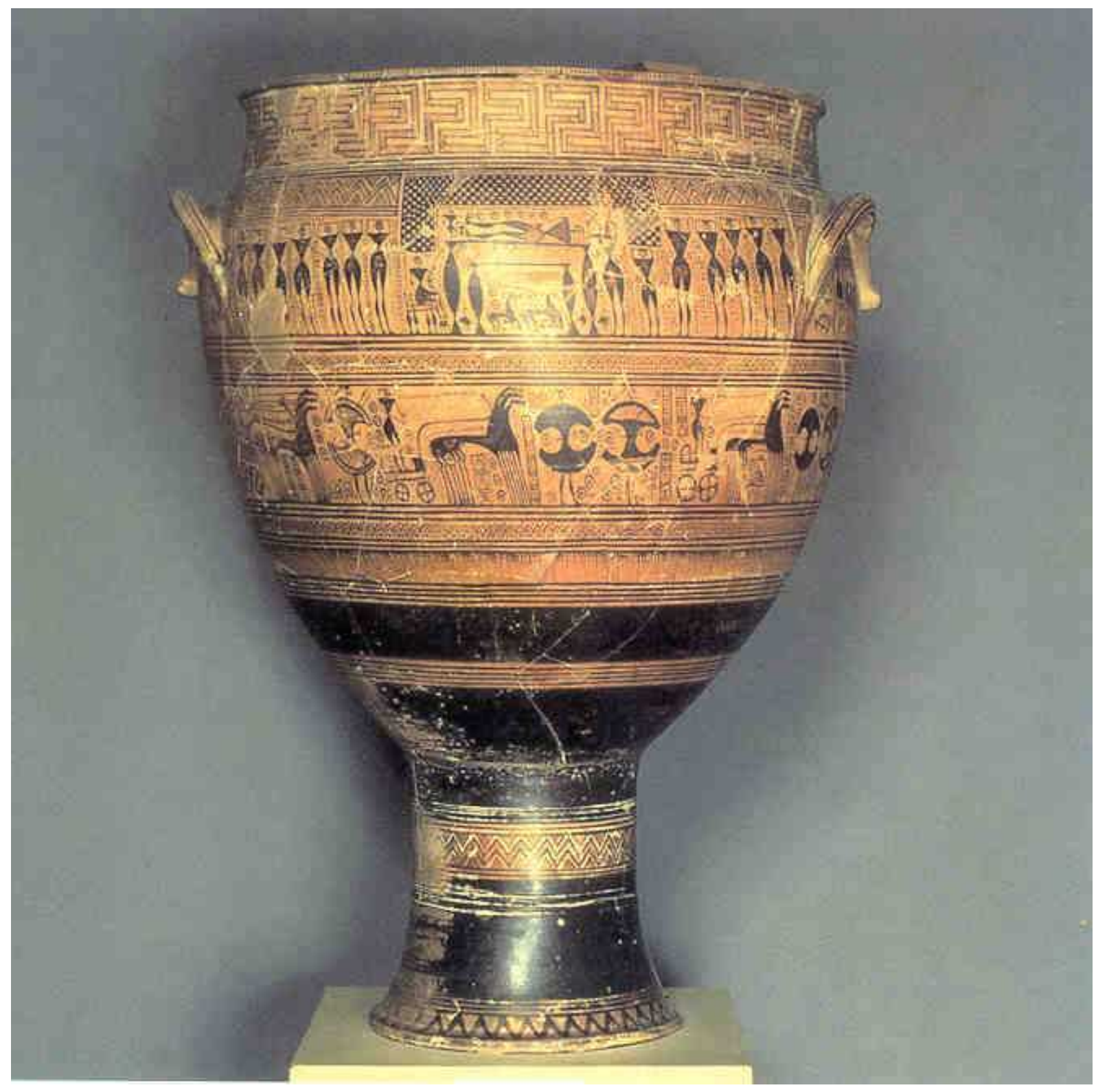

Fig. 4 Cratera Funerária proveniente do Cemitério do Dípilon, Atenas (c. 750-735 a.C.) atribuída ao Ateliê Hirschfeld. O painel superior mostra uma cena de prothesis. O painel inferior apresenta uma cena de ekphorá, ou procissão, seguida por homens armados a pé ou em carros. Altura: 108,3 cm; diâmetro: 72,4 cm. The Metropolitan Museum of Art, New York. Número de Inventário: 14.130.14.

$$
\text { Fonte da Figura: }
$$

<http://teachers.sduhsd.k12.ca.us/ltrupe/art\%20history\%20web/final/chap5Greece/VaseDipylon\%20Cemetary.jpg >. Último acesso em 29/11/2008. 


\subsection{Considerações Finais}

A incongruência mencionada entre a prática funerária predominante na poesia homérica, ou seja, a incineração, e a prática funerária predominante na época à qual o poema ambienta a sua narrativa, isto é, a inumação durante o Período Micênico, é vista, em geral, como um anacronismo cometido pelo poeta da llíada. Seria essa incongruência reflexo de um dos cochilos que Horácio, em sua Arte Poética, sugere em relação às passagens incongruentes em Homero? Bem, parece esse não ser o caso, pois teria sido um sono bastante longo (o canto XXIII inteiro e ainda mais 30 versos do canto XXIV!). Portanto, o poeta ao narrar as cenas de funerais conscientemente expõe a prática da incineração. Teria ele completo desconhecimento da prática dominante durante a época micênica, ou seja, a inumação? É difícil afirmar com veemência seu desconhecimento, pois Sarpédon parece ter sido inumado. Mesmo que esse argumento não seja absolutamente seguro, dada a dificuldade de interpretação do texto homérico, há ainda a prática do culto tumular e do culto heróico que pressupõe o conhecimento da localização desses túmulos do Período Micênico, cujo reaproveitamento durante o Período Geométrico pode sugerir que não havia um completo desconhecimento acerca da ocorrência da prática da inumação em 'épocas heróicas'.

A sobreposição de elementos característicos do Período Micênico e de períodos mais recentes, embora não se restrinja aos funerais, como será visto no capítulo 4, pode ser comparada à composição do quadro de Ingres (no frontispício da Introdução) e, de forma mais conveniente ao que aqui foi discutido, à composição do quadro de David, os 'Funerais de Pátroclo', cujo detalhe de Aquiles removendo o corpo do primo diante da pira fúnebre está no frontispício deste capítulo. David compõe um quadro cujos elementos constituintes residem na fusão entre a memória de um evento, histórico ou mitológico, e a representação com elementos contemporâneos a ele ou que, se não são contemporâneos, no mínimo, são verossímeis ao público de sua arte. Tal quadro e a poesia homérica, guardadas as devidas proporções, são presentificações de um evento passado através da arte de compor uma obra convincente ao seu público cujos padrões de criação estão entre a 
tradição e a genialidade individual. Cobrar da arte, em qualquer das suas formas, a representação fiel da realidade, quer passada, quer presente, é subestimar a natureza da própria arte. Se não cobramos isso de David, pois sabemos que é um artista que vive sob a égide do Neoclassicismo do século XVIII, por que cobraríamos de Homero?

A memória do artesão, os poemas épicos e o culto heróico fazem parte de um mesmo pano de fundo cultural e influenciam um ao outro à mesma medida que são meios de expressão de uma cultura comum compartilhada pelos indivíduos no interior de uma comunidade. O sono de Homero, na verdade, pode não ser uma metáfora muito feliz para explicar as incongruências acerca da prática funerária no interior do texto homérico. A rememoração de um passado heróico distante não é exclusividade da poesia, mas também a praticam os artesãos ao se utilizarem do esquema iconográfico de funerais e cortejo fúnebre; a própria comunidade também a realiza seja praticando o culto heróico ou rendendo a alguns de seus mortos as honras fúnebres dignas de um herói, ou quando encomendam um vaso com tal cena figurativa para marcar um túmulo, ou até mesmo quando olham para tal vaso ou presenciam uma performance da poesia homérica. 


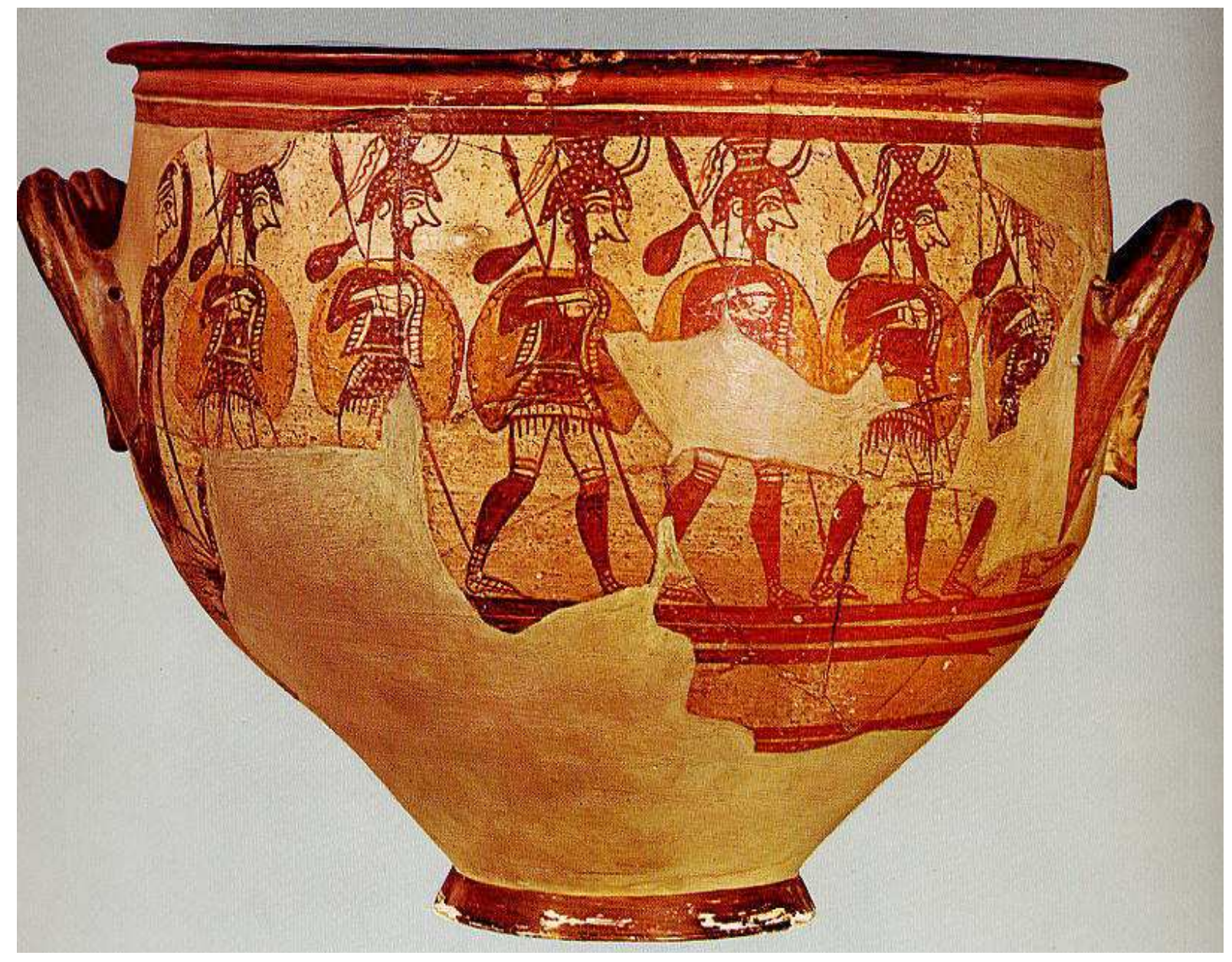

Capítulo 4 Armas 
"Quem conta um conto, aumenta um ponto."

Dito popular

Por ser a llíada um poema que trata da guerra, as armas constituem uma possibilidade de aproximação bastante profícua entre o poema e os documentos arqueológicos. Lorimer em sua obra Homer and the Monuments (1950), Courbin em seu artigo "La Guèrre em Grèce à Haute Époque" (1968) e, principalmente, Snodgrass em Early Greek Armour and Weapons (1964) compõem as três referências fundamentais para este capítulo no que concerne a cultura material que possivelmente possa apresentar alguma relação com a llíada.

As armas consideradas neste capítulo são divididas em duas partes: as armas de defesa e as armas de ataque (como em COURBIN, op.cit., p. 69-91). As cnêmides, a couraça e a armadura, o elmo e o escudo compõem as armas de defesa; e as armas de ataque são as espadas, as lanças, os dardos, o arco e a flecha; o carro, sendo mais um meio de transporte do que uma arma de guerra, será o último elemento, e a sua inserção nas armas de defesa é simplesmente uma questão de formalidade textual. Para cada peça do armamento, partir-se-á de uma leitura desses termos na Ilíada atentando para a existência de descrições das peças e suas adjetivações concernentes à forma e material; logo em seguida, voltar-se-á para a documentação arqueológica pertinente presente na bibliografia.

A documentação material abrangerá o Período Micênico, Sub-Micênico, Proto-Geométrico, Geométrico e, eventualmente, o Arcaico. O recorte geográfico corresponderá à área denominada Egeana, na seguinte ordem de prioridade: Hélade Continental, seguida das ilhas do Egeu e, por último, a Anatólia. Como o número total de achados ultrapassa o escopo de uma dissertação de mestrado, serão privilegiados os achados da Hélade Continental, e os achados provenientes da Hélade Insular serão mencionados quando houver total ausência de achados no continente ou quando a comparação entre os achados continentais e insulares for imprescindível. Quando houver profusão de achados da Hélade Continental, os achados provenientes de Micenas serão privilegiados. 
Esses documentos arqueológicos considerados serão basicamente de dois tipos: os próprios objetos, as suas representações e os tabletes em Linear B (estes apenas para o Período Micênico, evidentemente). Quando as evidências materiais de um objeto não contam com um exemplar físico, as representações de tais objetos serão fundamentais para a sua compreensão, como no caso dos escudos, por exemplo; e estas serão apenas consideradas se mostrarem a peça do armamento em questão sendo utilizada por um ser humano (portanto as representações de escudo em oito, que aparecem através da Idade do Bronze Recente como um elemento decorativo, não comporão o corpus por sua utilização estar mais relacionada a contextos religiosos do que bélicos); da mesma forma, as armas de divindades presentes na llíada não serão levadas em consideração.

O uso das armas provenientes dos Túmulos em Poço como evidências materiais passíveis de serem relacionadas aos poemas homéricos é bastante questionável se considerarmos que tais poemas só poderiam ter sido iniciados após o cerco a Tróia, cuja data é em torno de 1180 a.C. A evidência aponta para o desuso do tipo de equipamento encontrado nos Túmulos em Poço entre 1550 a.C. e o final do Heládico Recente III, portanto a semelhança entre objetos descritos por Homero e os objetos provenientes desses túmulos seria ou mera coincidência ou residiria em fatores lingüísticos cujo estudo não está livre de dificuldades até hoje intransponíveis. Ainda assim, eles farão parte da documentação arqueológica utilizada, pois, coincidência ou não, apresentam elementos elucidativos em relação a algumas peças do armamento utilizado pelo herói homérico, como as espadas com cravos em metais preciosos, por exemplo.

Apesar de o período abrangido nesse capítulo parecer extremamente amplo (do XVI até o fim VIII, eventualmente até o fim do VII), a documentação material não abrange a totalidade dos achados, mas somente aqueles passíveis de correspondência à narrativa iliádica, por ser esta uma dissertação que tem como partida tal poema, o que, dessa forma, também se reflete na metodologia empregada para construção desse capítulo, que parte da leitura da llíada e não do conjunto completo dos documentos arqueológicos. 


\subsection{Armas Defensivas}

\subsubsection{Cnêmides}

\section{llíada}

Através da fórmula euknhmidej Axaioi/ (Aqueus de belas cnêmides) mencionada 31 vezes na Ilíada (I, 17; II, 331; III, 86, 156, 304, 343, 370 e 377; IV, 80 e 414; V, 264, 324 e 668; VI, 529; VII, 57, 67, 172, 311, 430; XI, 149; XII, 141;XIII, 51 e 401; XIV, 49; XVII, 370; XVIII, 151; XIX, 74; XXIII, 272, 658 e 721; e XXIV, 800), Homero atribui aos aqueus não somente o uso de cnêmides para a proteção da parte inferior das pernas, mas transforma este aparato num elemento caracterizador, ou melhor, num epíteto dos aqueus.

No canto VII (v. 41), o epíteto aparece um pouco modificado; ao invés de eluknhmidej Axaioil,xalkoknhmidej Axa ioi/(Aqueus de brônzeas cnêmides) é dito pelo deus Apolo em um diálogo com Palas Atena para se referir aos aqueus. A menção, nessa passagem, ao material de que possivelmente são feitas chama a atenção do leitor por não ser freqüente; há apenas uma outra referência ao material a partir do qual elas são confeccionadas, no canto XVIII (v. 613), quando Hefesto

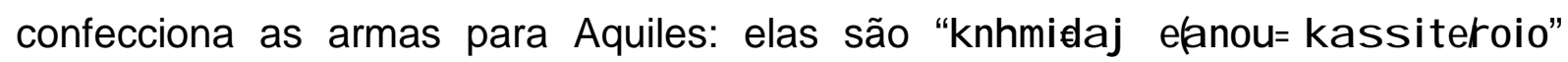
(cnêmides de luzente estanho). ${ }^{1}$

Além das passagens supracitadas, o termo "cnêmides" aparece em outras quatro passagens nas quais um herói é descrito vestindo seu armamento para a batalha, que são conhecidas como 'cenas de armamento': Páris (III, 328-338), Agamêmnon (XI, 15-46), Pátroclo (XVI, 130-147) e, finalmente, Aquiles (XIX, 367399). Em todas essas quatro cenas, as cnêmides são o primeiro item a ser vestido pelo herói. A explicação para isso pode residir no caráter formular dessas passagens ou, pensando sob um aspecto prático, talvez esteja no fato de ser mais fácil calçálas antes de vestir o restante do armamento, principalmente a couraça (SAGE, 1996, p. 7). A fórmula utilizada para descrever o herói calçando as cnêmides nas quatro

\footnotetext{
${ }^{1} \mathrm{O}$ bronze é uma liga metálica de cobre e estanho.
} 
cenas de armamento (III, 330-331; XI, 17-18; XVI, 131-132; XIX, 369-370) é a mesma:

$$
\begin{aligned}
& \text { knhmi } \notin a j \text { meh prw } \\
& \text { kal a l, argurebis in episfuribij araruiaj: }
\end{aligned}
$$

As cnêmides, primeiro, em torno das pernas coloca, belas, com ajustes de prata sobre os tornozelos. ${ }^{2}$

Essa fórmula é particularmente interessante por apresentar um detalhe na composição das cnêmides: algum tipo de mecanismo para a sua fixação à perna. Pensando na etimologia do termo epis furibij, percebemos que ele é composto de duas palavras: epi, cujo sentido primeiro é "sobre", e sfuroh, cuja acepção mais precisa seria "tornozelo"; seguido pela forma do particípio perfeito do verbo a ta ri\$ kw que significa "ajustar". Epis furibij a ta ruilaj se refere a uma espécie de mecanismo de ajuste das cnêmides à perna do usuário localizado nos tornozelos; essa expressão formular foi traduzida tanto por Carlos Alberto Nunes quanto por Haroldo de Campos, em suas respectivas traduções da llíada, como "fivelas". Na verdade, não há nenhum termo em tais versos que signifique precisamente "fivelas", e o mecanismo de fixação poderia ser composto por algum tipo de correia ou fio que servisse ao mesmo propósito. O termo que precede tal expressão é a t gur ebis in e significa "de prata". Por conseguinte, teríamos algum mecanismo de ajuste feito de prata que se localizaria sobre os tornozelos. ${ }^{3}$

Portanto, na llíada, o único termo utilizado para se referir às cnêmides é knhmi $\nLeftarrow$ jej (o termo aqui é mantido no plural, pois seu uso na llíada nunca é no singular); elas são um elemento caracterizador dos aqueus; o único adjetivo que a particulariza quanto ao material é x a l k ol (bronze) e nada se pode depreender de

\footnotetext{
${ }^{2} \mathrm{O}$ termo empregado nessas passagens de armamento do guerreiro não é exatamente "e $\mu k n h$ mi dej " como no epíteto dos Aqueus, mas knhmi ła j (...) kal a j (vv. 330-1), ou seja, o prefixo "elu’fé substituído pelo adjetivo "k a I a ", mas o sentido é o mesmo.

${ }^{3}$ No canto XVIII (v. 458), quando Tétis pede a Hefesto que confeccione novas armas para seu filho Aquiles, ela se utiliza da expressão "kal a j knhmi łaj episfuribij a la ruiaj" (belas cnêmides com ajustes sobre os tornozelos), mas o termo "a l gu r ebi s in" (de prata) não aparece.
} 
sua forma e uso além da presença de um mecanismo de ajuste às pernas do usuário, cujo material, na Ilíada, é a prata, e se afixa sobre o tornozelo.

\section{Documentação Arqueológica}

\section{Período Micênico}

\section{Exemplares}

Desde as escavações de Schliemann, em Micenas, foram encontrados objetos que remetem ao uso de cnêmides durante a Idade do Bronze. No Círculo Tumular $\mathrm{A}$ de Micenas, mais precisamente nos túmulos IV, $\mathrm{V}$ e $\mathrm{VI}$, datados do Heládico Recente I e II (1550-1500 a.C.), Schliemann (1976 [1880], p. 230, fig. 338; p. 328, fig. 519) encontrou objetos cuja provável finalidade fosse servir de fivela ou ornamento das cnêmides (p. 139, fig. C1). Uma das extremidades desses objetos, de forma anelar, seria presa a uma espécie de calção e a parte que se abre "em asa" prenderia a cnêmide em volta da perna. Embora essa utilização tenha sido questionada (LORIMER, op.cit., p. 253-254), o fato de algumas dessas fivelas term sido encontradas em torno de fêmures em alguns túmulos como, por exemplo, um encontrado no sepulcro IV no interior do Círculo Tumular A que apresentava um ornamento de ouro envolto em sua extremidade inferior, corroboraria essa teoria (SCHLIEMANN, 1976 [1880], p. 230, fig. 338). O uso do calção também é atestado por alguns achados como, por exemplo, um ornamento de ouro encontrado por Schliemann no sepulcro III do Círculo Tumular A (fig. C2) (Ibidem, p. 174, fig. 253).

Como nem Schliemann (Ibidem, p. 134) nem Tsountas (op.cit., p. 162) encontraram qualquer exemplar de cnêmides em metal, ambos assumiram que elas devessem ser confeccionadas em material perecível como tecido ou couro. Além disso, Homero se refere a cnêmides de metal somente duas vezes (VII, 41 e XVIII, 613; supra) em toda a Ilíada; e na Odisséia a passagem XIV, 228-9 refere-se a Laerte usando cnêmides de couro de boi para proteger as pernas de espinhos enquanto trabalha no pomar do palácio.

Durante o século XX, foi encontrado no Túmulo em Câmara 15, em Micenas, um objeto (datado entre 1300 e 1250 a.C) que remete ao uso de um outro aparato 
exatamente sobre o tornozelo (cf. COURBIN, 1986, p. 79, pl. 8:3. SNODGRASS, 1964, p. 4, nota 6; p. 72, nota 2; p. 88) como indica o termo ep is f u ribn (fig. C3).

Embora as cnêmides não componham um achado abundante relativo ao Período Micênico, a maioria das cnêmides encontradas durante o século XX é confeccionada em bronze, o que remeteria ao termo xal koknhmidej. Apesar do estado bastante danificado, o mais antigo exemplar de cnêmides já encontrado na Grécia corresponde à descoberta realizada em 1960 em Dendra, a poucos quilômetros a sudeste de Micenas, no Túmulo 12, datado de cerca de 1400 a.C. (fig. C4). ${ }^{4}$ A chapa de bronze que a compõe é bastante fina, da espessura de uma folha de papel (cerca de $3 \mathrm{~mm}$ ), e se torna cada vez mais fina em direção às suas extremidades inferiores e superiores; tais extremidades contêm pequenas perfurações e algumas delas ainda continham resquícios de couro, que comporia a camada intermediária entre o metal e um forro feito de algum outro material perecível, talvez algum tipo de tecido, como o linho, por exemplo (FORTENBERRY, 1991, p. 623). Dada a fina espessura do bronze, estudiosos tendem a pensar que a proteção, na verdade, viria da sobreposição dos materiais ao invés da própria placa de metal, que serviria mais como um elemento decorativo do que a um propósito defensivo (Ibidem).

Esse exemplar de cnêmides não apresenta resquícios de qualquer material utilizado para amarrá-las à perna do usuário. Isso fez com que se supusesse que ela fosse provavelmente anexada à perna apenas por ajuste e seria a precursora de um modelo que fora encontrado em Olímpia datado do século VI a.C. (fig. C5), embora o uso de tiras de couro, no exemplar de Dendra, para prendê-las abaixo do joelho e acima do tornozelo (epis f u rionn) não seja totalmente excluído.

Um outro modelo de cnêmides foi encontrado no interior de um túmulo em Enkomi, na ilha de Chipre, e consiste em meras chapas elípticas de bronze, que datam de cerca de 1200 a.C. (fig. C6). Elas eram flexionadas e amarradas com um fio de bronze e não medem mais do que $30 \mathrm{~cm}$ (SNODGRASS, 1967, p. 31). Provenientes de um outro túmulo também de Enkomi são dois exemplares datados

\footnotetext{
${ }^{4}$ N. Verdelis, The Cuirass Tomb and Other Finds at Dendra I: The Chamber Tombs (SIMA 5.1, Goteborg 1977) 45-48, fig. 11, pl. XXI; apud Fortenberry, p. 623, 1991.
} 
de pouco depois de 1200 a.C. que demonstram algumas diferenças entre si e, portanto, comporiam dois conjuntos diferentes de cnêmides. ${ }^{5} \mathrm{O}$ exemplar melhor preservado (fig. $\mathrm{C}$, exemplar inferior) é decorado com pequenas protuberâncias e apresenta um fio de metal na borda, talvez para possibilitar a colocação de correias. O outro exemplar (fig. $\mathrm{C} 7$, exemplar superior) não apresenta decoração, mas é munido de um anel de metal na borda também para a colocação de correias. Um outro par de cnêmides foi encontrado no túmulo denominado "Túmulo do Guerreiro" em Kallithea, na Hélade continental, datado do Heládico Recente IIIC (1190-1130 a.C.); elas são decoradas com linhas e pequenas protuberâncias circulares e apresentam um tipo de gancho de metal nas extremidades para amarrar correias ou tiras (fig. C8) (VERMEULE, 1960, p. 13, pl.5). Ainda outro par apresentando círculos de pequenas protuberâncias, semelhante às do Túmulo do Guerreiro, foi encontrado numa Câmara Tumular na face sul da Acrópole de Atenas e data do Heládico Recente IIIB2 e IIIC (1230-1130 a.C.) (fig. C9) (cf. COURBIN, op.cit., p. 79, nota 77, pl. 8:1).

\section{Representações}

Além desses exemplares resgatados em escavações, há representações de cnêmides nas pinturas parietais de Micenas (fig. C10, C11 e C12), Orcômenos, Tirinto e Pilos (fig. C13). Nessas cenas de afrescos, elas são geralmente representadas com três a sete listras horizontais nas extremidades inferior e superior, o lado frontal superior avança em direção ao joelho formando uma curva, enquanto a parte de trás é mais baixa chegando às vezes ao meio da barriga da perna, talvez para facilitar a flexão dos joelhos. As listras inferiores ou superiores podem indicar o uso dos cadarços para amarrar as cnêmides feitas de material perecível, couro ou tecido, à perna. Além dessas listras inferiores e superiores, há em quatro exemplares de afrescos de Pilos uma espécie de linha curva acentuada na perna direita (ver detalhe da perna direita da fig. C13). P. Cassola Guida (apud FORTENBERRY, 1991, p. 625) sugeriu que essa linha curva representasse a

\footnotetext{
${ }^{5}$ Murray, Smith e Walters, Excavations in Cyprus, 16, 51, fig. 26 (apud Snodgrass, 1964, p. 86, nota 44; cf. Courbin, 1968 , p. 79 e pl. 8:2).
} 
cobertura de bronze que seria sobreposta às cnêmides de couro; a idéia foi reafirmada por H.W. Catling (apud Ibidem).

Além dos afrescos, há também representações de guerreiros usando cnêmides na Estela dos Guerreiros (fig. C14) (LORIMER, op.cit., p. 251 e pl. II, fig. 2), encontrada em Micenas, e em vasos de cerâmica como, por exemplo, o próprio Vaso dos Guerreiros (conferir detalhe na fig C15.); um fragmento do que foi denominado "Vaso do Noivo", onde uma figura masculina conduz um cavalo (fig. C16) (Ibidem, p. 251 e pl. XII, fig. 1); e num outro fragmento cerâmico também encontrado em Micenas (fig. C17) (Ibidem, p. 251 e pl. XII, fig. 2).

É importante ressaltar que os exemplares de cnêmides datados do Período do Bronze são, em geral, ligeiramente mais curtos do que as cnêmides representadas nos afrescos e nos fragmentos cerâmicos do mesmo período.

Em Homero seu uso é exclusivamente aos pares, supondo-se a partir do uso do termo ser sempre no plural (supra), mas em alguns túmulos, principalmente dos séculos XIV e XIII a.C., foram encontradas apenas uma perna e não um par (figs. C6 e C7). Isso se encaixa às figuras representadas nos afrescos de Pilos e, somado à fina espessura do metal, fez com que se pensasse que, durante esse período, o uso de cnêmides em metal era apenas decorativo ou expressava algum tipo de status, e que o uso do par completo teria se iniciado apenas a partir do Heládico Recente IIIC (c. 1190 a.C.) (Ibidem, p. 251). ${ }^{6}$

\section{Linear B}

Apesar de seu uso durante o Período Micênico ser atestado pela cultura material, não há menção de cnêmides nos tabletes em Linear B.

\footnotetext{
${ }^{6}$ Os dois pares encontrados em Kallithea (fig. C8) e em Atenas (fig. C9) datam exatamente do Heládico Recente IIIC.
} 


\section{Exemplares}

Durante a Idade do Ferro (1100-750 a.C.), não há vestígios materiais que atestem o uso de cnêmides na Hélade (DESBOROUGH, 1964, p. 63-4), ${ }^{7}$ embora a sua confecção exclusivamente em material perecível não seja descartada para esse período. Elas reapareceriam no final do Período Geométrico em Creta de onde provêm um par fragmentário em bronze de uma thólos em Kavousi, datado de pouco antes de 700 a.C., e outros dois exemplares (que não compõem um par) de um santuário em Praisos de data pouco posterior ao primeiro. ${ }^{8}$ Os fragmentos de Kavousi (SNODGRASS, 1964, p. 87) sugerem um par relativamente pequeno e apresentam decoração em repoussé que lembram os exemplares do Período Micênico, embora mostrem melhor moldagem à perna.

\section{Período Arcaico}

Ao falar das cnêmides como elemento do armamento do hoplita, Snodgrass (1967, p. 52-53) nota que sua adoção foi um pouco posterior em relação a outros elementos. Ele baseia sua suposição dizendo que as mais antigas evidências de seu uso pelo exército hoplítico são as representações de cnêmides em vasos de cerca de 675 a.C, ${ }^{9}$ e que elas são ressaltadas por incisões ou pintadas em cor mais clara do que o restante da composição. No final do século VII a.C., uma série de vasos no estilo Proto-Coríntio, principalmente um vaso pintado em técnica policromática, denominado Chigi (fig. C18), mostra claramente o uso das cnêmides por parte de duas falanges de hoplitas a ponto de iniciar uma batalha.

As cnêmides desse período seriam bastante distintas do tipo encontrado durante o Período Micênico, sendo mais alongadas, indo da rótula até o peito do pé,

\footnotetext{
${ }^{7}$ Embora uma série de achados tenha ocorrido na Europa Central com as mesmas características do tipo micênico, como a decoração e a amarração, as datações propostas por Merhart (apud Snodgrass, 1964, p. 86) para tais exemplares ainda são controversas.

${ }^{8}$ Devido ao tamanho bastante reduzido, os exemplares de Praisos têm sido interpretados como objetos votivos. Snodgrass, 2000 [1971], p. 273 e 1964, p. 87.

${ }^{9}$ Note-se que os vasos do Período Geométrico não apresentam suas figurações de guerreiros usando cnêmides quer por serem esquemáticas ou simplesmente por não terem um referencial na realidade contemporânea.
} 
e sem sinais de decoração ou uso de correias ou cadarços, o que, segundo Snodgrass, torna a perspectiva de continuidade de seu uso entre o Período Micênico e o Período Geométrico improvável. ${ }^{10}$

O exemplar de cnêmides do século VI, proveniente de Olímpia (supra, fig. C5) de $37 \mathrm{~cm}$ de altura, cuja forma se ajusta à anatomia da perna, representaria o modelo corrente durante esse período.

\section{Conclusão}

Snodgrass (1964, p. 89-90) supõe que a re-introdução do uso das cnêmides, se realmente ela se tornou um item desconhecido durante a maior parte da ldade do Ferro, pode ou ter sido através de Creta, de onde provêm os únicos resquícios de exemplares do Período Geométrico, ou através dos monumentos micênicos, principalmente no que diz respeito à similaridade entre as figurações de cnêmides nas pinturas parietais do Período Micênico (figs. C10-C13) e a cnêmide do Período Arcaico (figs. C5 e C18); e que, se esse conhecimento visual não existisse, a épica o proveria. Este argumento assume como pressuposto a preservação da memória do uso de cnêmides desde o Período Micênico até o final do século VIII a.C. através da poesia épica e, portanto, as cnêmides em Homero seriam uma reminiscência do estrato micênico.

A hipótese defendida por Van Wees (2004, p. 252) de que a data mais apropriada para fixação do texto iliádico seria entre o final do século VII e início do século VI a.C., em contrapartida, tornaria as cnêmides um artefato já conhecido através da utilização das mesmas, como demonstra o Vaso Chigi do mesmo período em questão (c. 620 a.C.); ainda assim, o argumento de Snodgrass que propõe a épica como um recurso para o seu conhecimento não seria necessariamente invalidado, mas a referência a elas na poesia homérica não seria necessariamente um componente exclusivo do estrato micênico tanto quanto do estrato contemporâneo à sua composição.

\footnotetext{
${ }^{10}$ Em contrapartida, o próprio Snodgrass (1964, p. 87) observa que as representações parietais e vasculares de cnêmides provenientes de Micenas (figs. C10, C11 e C12) mostram, em geral, pares mais alongados do que as cnêmides contemporâneas encontradas.
} 
Não é possível concluir a partir da falta de evidência material se as cnêmides deixaram ou não de ser usadas durante a Idade do Ferro, mas existe uma grande possibilidade de elas não terem sido confeccionadas em metal nesse período, dada a escassez dos achados. Logo, a presença de cnêmides em bronze em Homero, por mais rara que seja a referência (V, 41 e XIII, 613 apenas), ou é um 'micenismo', ou um indício de que a data para os poemas não deve estar antes do século VII, ou são interpolações. A primeira hipótese é defendida por Snodgrass (1964, p. 173), a segunda por van Wees (2004, p. 251) e a terceira, por Lorimer (op.cit., p. 252).

A ausência de cnêmides dentre os achados na região da Anatólia talvez seja uma indicação do motivo pelo qual Homero transforma o uso de cnêmides num elemento caracterizador dos aqueus.

\subsubsection{Armadura e Couraça}

\section{llíada}

Como a fórmula edlknhmidej Axaioil (31 vezes, supra), Axaiw\# xal koxitwhwn (I, 371; II, 47, 163, 187, 437; III, 127, 131, 251; IV, 199; VI, 454; VII, 275, 444; VIII, 71; X, 136, 287, 367; XII, 352; XIII, 272; XV, 56; XVII, 414; XVIII, 105; XXIII, 575; e XXIV, 225) também é utilizada para caracterizar os aqueus. Mas diferentemente de ejknhmi $F$, o termo xalkoxikwn também será utilizado para caracterizar dentre os aqueus, mais precisamente os argivos (IV, 285 e XII, 354), os epeios (IV, 537 e XI, 694), os cretenses (XIII, 255) e os beócios (XV, 330) ${ }^{11}$, e duas únicas vezes para caracterizar os troianos (V, 180 e XVII, 485).

Embora xitwn seja o termo grego para 'túnica' (em II, 42, por exemplo, Agamêmon veste uma túnica ao sair do leito), além das ocorrências de x a l k ox i ł w n como epíteto, há apenas mais uma única ocorrência em que o xitwn é evidentemente de bronze (XIII, 439-440). Há, portanto, duas maneiras de se interpretar esse epíteto: uma é tomá-lo como um exagero poético significando que os guerreiros eram revestidos metaforicamente de armas de bronze; a outra é

\footnotetext{
${ }^{11}$ Os argivos, os epeios, habitantes de Elide (Il., II, 619), os cretenses e os beócios lutam todos contra Tróia e talvez se insiram na caracterização geral de 'aqueus'.
} 
encontrar na armadura de Dendra uma possível referência (infra e fig. AC1). Lorimer, que escreveu antes da descoberta da armadura de Dendra, associou o epíteto xal koxitwnej às vestimentas dos guerreiros representados no Vaso dos Guerreiros (LORIMER, op.cit., p. 208-209).

A couraça é geralmente designada como qw th h (por exemplo, llíada, II, 544; III, 332) em Homero. Quanto ao material em que é confeccionada, a couraça de Ájax Telamônio e de Ânfio, no canto II, 529 e 830, respectivamente, é designada pelo termo I inogwthc, ou seja, 'couraça de linho'. Outras passagens indicam que eram em bronze (XIII, 397-8, por exemplo) e o termo xal keogwthkej (couraça de bronze) ocorre duas vezes (IV, 448; VIII, 62).

Uma fórmula de combate usada em IV, 132-3 e XX, 414-5 por muito tempo tem instigado os estudiosos de Homero (LORIMER, op.cit, p. 248-250). Verdelis (apud KING, 1970, p. 295) associa zws throj oxhej com os ajustes das faixas da armadura de Dendra (infra). O dipl obj qwthc ele interpreta como as partes da frente e das costas do próprio corselete.

As passagens V, 98-99, 188-9; XIII, 507, 587; XV, 529-30; XVII, 314 se utilizam da expressão qw thk oj guk I on. A palavra gukl on se refere a algo curvo e posteriormente seria usada para descrever as duas placas que constituem 0 corselete hoplita, mas as interpretações para essa palavra em Homero ainda são controversas (cf. KING, 1970, p. 295).

Alguns detalhes são fornecidos pelo poeta nas cenas de armamento, como, por exemplo, para a couraça de Agamêmnon (XI, 19-25) com suas dez listras de enamel, doze de ouro e vinte de estanho, mas esses detalhes ainda não encontraram paralelos na cultura material $e$, portanto, não tomarão parte no presente estudo sobre os armamentos. 


\section{Documentação Arqueológica}

\section{Período Micênico}

\section{Exemplares}

A descoberta realizada pela expedição greco-cueca, em Dendra, na década de 1950, revelou a primeira armadura de metal, composta de doze partes, dentre elas um qw thc, mais uma série de faixas em bronze dispostas horizontalmente na parte inferior, com proteção para o pescoço e para os ombros, que data do final do século XV a.C. (fig. AC1). Com essa descoberta, as referências de Homero aos aqueus xal koxitwhwn talvez encontrem um paralelo na cultura material (KING, 1970, p. 295).

Outros achados que corresponderiam a um aparato para a proteção do tórax são placas de bronze (fig. AC2) encontradas em Archalachori, Creta, e são interpretadas como reforços para couraças de couro ou linho (l i no qw th h ).

\section{Linear B}

Em Cnossos e Pilos foram encontrados tabletes em Linear B que são inventários de peças de armamento onde há referência a couraças, principalmente o tipo de Dendra (COURBIN, op.cit., p. 78). Em torno de 140 tabletes de Cnossos (c. 1350 a.C.) (fig. AC3) e 12 de Pilos (c. 1250 a.C.) apresentam o ideograma que é interpretado como uma armadura ou corselete. Nos tabletes de Pilos aparece também a inscrição to-ra-ke, que não deixa dúvidas sobre a interpretação. Embora o material não seja especificado nos tabletes, há um tablete de Pilos que cita o linho e outro que se refere a 30 chapas, 20 grandes e 10 pequenas (CHADWICK, 1995, p. 111). 


\section{Exemplares}

Durante a Idade do Ferro, praticamente não há registros de armadura ou couraça em metal, o que não significa que não tivessem sido confeccionadas em outro material que fosse perecível (como para as cnêmides) ou que elas fossem destruídas para que o metal fosse reutilizado (SNODGRASS, 1967, p. 41).

Depois dos achados micênicos, as couraças em metal só vão reaparecer no final do século VIII a.C. no formato denominado pelos arqueólogos de "bell-shape" ou em forma de sino (fig. AC4). O único exemplar desse período, proveniente de Argos, é composto de duas partes, a frontal e a posterior, que se juntam nas laterais, talvez explicando o termo gual on em Homero (supra).

\section{Conclusão}

Apesar de os exemplares de Dendra e de Argos provarem a existência de uma armadura durante a Idade do Bronze e de um corselete para o Período Geométrico, ambos em metal, eles são exemplares bastante isolados e não permitem conclusões decisivas acerca das referências a tais tipos na narrativa iliádica.

\subsubsection{Elmo}

\section{llíada}

Dentre as peças de armamento da llíada, o elmo é a que encontra maior profusão de termos designativos. Eles são k of uj ${ }^{12}$ (III, 362, 369; IV, 459; V, 4; VI, 9 , 470, 472, 494; XI, 351, 375; XII, 160, 184; XIII, 131, 132, 188, 265, 341, 544, 614, 714; XIV, 372, 420; XV, 125, 535; XVI, 70, 214, 216, 338, 413, 579; XVII, 269, 295; XVIII, 611; XIX, 359; XX, 162, 289, 398; XXI, 50; XXII, 112, 314), kuneh (III, 316,

\footnotetext{
${ }^{12}$ Anatole Bailly, na entrada para k or uj, o define como elmo em metal por oposição a k u ne h, que seria o elmo quer em pele de cão ou qualquer tipo de couro, e menciona a passagem XII, 183, 'etc' como exemplo de passagens onde essa diferença não é observada.
} 
336; V, 743, 845; VII, 176, 182, 187; X, 257, 261, 335, 458; XI, 41; XII, 183, 384; XV, 480; XVI, 137, 793; XVII, 294; XX, 397; XXIII 861), trufall eia ${ }^{13}$ (III, 372, 376; V, 182; X, 76; XI, 352; XII, 22, 339; XIII, 530, 577; XVI, 795; XVIII, 458; XIX, 380, 382; XXIII, 799), ph/ hc ${ }^{14}$ (VIII, 308; XIII, 527, 805; XIV, 498; XV, 608, 647; XVI, 105, 797; $X X, 482)$, s tef a hh ${ }^{15}$ (VII, 12; X, 30; XI, 96) e ka ta $i \neq u c^{16}$ (X, 258), que é um a pa c l egomenon.

Os epítetos atribuídos aos personagens relacionados ao elmo na llíada são koruqa ibl oj (II, 816; III, 83, 324; V, 680, 689; VI, 116, 263, 342, 359, 369, 440, 520; VII, 158, 233, 263, 287; VIII, 160, 324, 377; XI, 315; XII, 230; XV, 246, 504; XVII, 96, 122, 169, 188, 693; XVIII, 21, 131, 284; XIX, 134; XX, 38, 430; XXII, 232, $249,337,355,471)$ que, das 39 passagens citadas, 38 se referem a Heitor e uma a Ares (XX, 38) e cujo significado é 'que agita a crina de seu elmo'; kor uqa l $\notin$ (XXII, 132) se refere a Aquiles e tem o mesmo significado de koruqaibl oj; xal kokorusthj (V, 699; VI, 199, 398; XIII, 720; XV, 221, 458; XVI, 358, 536, 654) que das 9 passagens apenas $\mathrm{VI}, 199$ se refere a Sarpédon, todas as outras se referem a Heitor significando 'provido de elmo de bronze'; e k or us th' (IV, 457; VIII, 256; XIII, 201; XVI, 603; XVIII, 163) que significa simplesmente 'guerreiro provido de elmo'.

Os materiais usados na confecção dos elmos também são especificados em algumas passagens como ktilleoj (X, 335 e 458), que se refere ao elmo ou gorro de pele de fuinha de Dólon; tau úeioj (X, 258) para se referir ao elmo que Trasímedes dá a Diomedes que é de couro de touro; x a l keibj (X, 30; XII, 184; XX, 398), xal khthj (III, 316; XIII, 714; XV, 535; XXIII, 861) e eukal koj (VII, 12) que especificam o material como sendo o bronze; e xrus ei oj (V, 744; XVIII, 612), que

\footnotetext{
${ }^{13}$ Anatole Bailly define o termo como elmo com quatro saliências.

${ }^{14}$ Anatole Bailly define o termo como elmo com penacho flutuante cuja origem é obscura.

${ }^{15}$ Anatole Bailly o define como todo objeto que se coloca em torno da cabeça: pode ser a borda do elmo ou o próprio elmo. A passagem XVIII, 597 refere-se a diademas, grinaldas ou coroas femininas.

${ }^{16}$ Anatole Bailly o define como um elmo baixo sem penacho.
} 
evidentemente indicam ornamentos em ouro e não que todo o elmo era feito em ouro. $^{17}$

Alguns dos componentes dos elmos também são especificados sob os termos ima '] (correia de couro; III, 371, 375), I of oj (penacho; III, 337; VI, 469; XI, 42; XIII, 615; XV, 537; XVI, 138; XVIII, 612; XIX, 383; XXII, 316), k u mba x oj (cimeira de um elmo; XV, 536), ox eul (barbela de um elmo; III, 372), piᅣoj (feltro que reveste o interior de um elmo; X, 265), f a / a r a (copo de brida em metal que orna ou reforça um elmo; XVI, 106), f a l oj (cimeira de um elmo; III, 362; IV, 459; VI, 9; XIII, 132, 614; XVI, 216, 338) e e heir a i (crina de cavalo; XI, 382; XXII, 315).

Para alguns elmos, Homero também dá indicações e descrições de seus componentes específicos ou características construtivas como ippioxaithj (feito de crina de cavalo; VI, 469), i ppoda s ei a (provido de uma espessa crina de cavalo; III, 369; IV, 459; VI, 9; XII, 614, 714; XV, 535; XVII, 295) ou ippok omoj (provido de crina de cavalo; XII, 339; XIII, 132; XV, 335; XVI, 216, 338, 797), ippourij (provido de um rabo de cavalo, III, 337; VI, 495; XI, 42; XV, 481; XVI, 138); a II of oj (sem penacho; X, 258), a f a l oj (sem cimeira; X, 258), a mf if a l oj (com duas cimeiras; V, 743; XI, 41), tetrafal oj (com quatro cimeiras; XII, 384; XXII, 315), tetrafa/hroj (com quatro cimeiras; V, 743; XI, 41), a ul w fij trufal eia (V, 182; XI, 353; XIII, 530; XVI, 795), triptuxoj (de três partes ou camadas, XI, 353), xal kopathoj (de lados ou junções de bronze, XII, 183; XVII, 294; XX, 397) e pol ukes toj (decorado, III, 371).

Infelizmente, não há como relacionar os diferentes termos aos diferentes tipos de elmos encontrados fisicamente ou suas representações. Talvez a única exceção seja o elmo de presas de javali descrito no canto $X, 261-5$ que é referido como kuneh; ainda assim, não há como assegurar que todas as vezes em que o termo

\footnotetext{
${ }^{17}$ Alguns termos como I a mp rol' (XVII, 269; XIII, 132), f a einol (III, 339; X, 76; XI, 104; XIII, 527; 805; XV, 538; XXII, 314) e pa ha iqoj (XIV, 372) qualificam os elmos como brilhantes e resplandecentes; e bria rol' (XI, 375; XVI, 413; XVI, 579; XVIII, 611; XIX, 381; XX, 162; XXII, 112) indica sua robustez.
} 
ocorre ele se refira a tal espécime e, a partir das suas ocorrências, o termo parece ter uma aplicação geral.

\section{Documentação Arqueológica}

\section{Período Micênico}

O elmo de presas de javali (fig. E1) descrito no canto $X, 261-5$ na llíada encontrou seu paralelo na cultura material com a descoberta de Wace num Túmulo em Câmara de Micenas (COURBIN, op.cit., p. 76), sendo ainda o exemplar de elmo mais antigo já encontrado. No Túmulo 18 de Dendra, de onde provém a armadura (supra), em torno de 50 presas de javali e duas proteções laterais em bronze foram encontradas (fig. AC1); logo, o elmo poderia ser composto de partes confeccionadas de diferentes materiais.

Um exemplar de elmo inteiramente em bronze foi encontrado em um túmulo de Cnossos (fig. E2), em Creta, datado do século XV a.C., contemporâneo às presas de javali e às proteções laterais de Dendra, mostrando que diferentes tipos de elmos poderiam ser usados contemporaneamente.

\section{Representações}

Embora exemplares físicos de elmos tenham sido encontrados, para compreender alguns dos detalhes que Homero cita para esse artefato, temos de recorrer a representações, como, por exemplo, a presença de chifres e cristas ou plumas. O Vaso dos Guerreiros (1200 a.C.) em sua face A mostra um tipo de elmo que apresenta uma saliência em forma de chifre na parte frontal e uma protuberância em cima da cabeça de onde sai uma espécie de pluma ondulante. A presença de chifres em elmos também é atestada por uma estatueta proveniente de Enkomi, Chipre, datada do Heládico Recente IIIC (fig.E3).

A face B do Vaso do Guerreiro apresenta um outro tipo de elmo, talvez confeccionado em pele de animal num estilo 'porco espinho'. 


\section{Linear B}

O elmo é atestado em Linear B através de um ideograma encontrado no tablete KN191 de Cnossos (fig. E5). Esse ideograma aparece em quatro tabletes com o termo ko-ru associado a ele.

\section{Idade do Ferro}

Há apenas um exemplar proveniente do túmulo XXVIII de Tirinto datado de 1050 a.C. (fig. E6).

Junto com a couraça de Argos (supra) do Período Geométrico, foi encontrado um elmo totalmente em bronze cuja crista também é confeccionada nesse material (fig. E7 e E8) (COURBIN, op.cit., pl 5:4).

\section{Representações}

As representações em vasos do Geométrico caracterizam a utilização dessa peça do armamento através da representação de pluma na cabeça da figura humana (prancha escudo, fig. ES6).

\section{Conclusão}

Tanto durante a Idade do Bronze quanto durante a Idade do Ferro, vários tipos de elmos eram usados na área do Egeu e isso talvez explique os diferentes termos utilizados por Homero para designá-los (supra).

É certo que elmos em metal eram conhecidos durante a Idade do Bronze e também no final do século VIII a.C.; mais do que isso, acredita-se que eles eram comuns o suficiente em ambos os períodos para serem um peça padrão do equipamento (SNODGRASS, 1964, p. 171).

\subsubsection{Escudo}




\section{llíada}

De modo geral, o escudo em Homero, tanto dos aqueus quanto dos troianos, é descrito como circular e composto de várias camadas de couro de boi, às vezes reforçado com elementos em metal.

Embora os escudos melhor descritos na Ilíada sejam o de Aquiles (XVIII, 470607), o de Agamêmnon (XI, 32-40), o de Ájax (VII, 219-223; 245-246; XI, 485; XVII, 128), e o de Heitor (VI, 117-118; VII, 250; XI, 61; e III, 157), eles apenas contribuem para o estudo do escudo à medida que fornecem características que não sejam extremamente particularizantes, como os detalhes em metais preciosos ou as ricas decorações.

$\mathrm{Na}$ Ilíada há dois termos usados por Homero para designar 'escudo': a \$ pi '], com 94 ocorrências, e que é o termo que continuaria a ser usado para designar o escudo do hoplita nos períodos posteriores; s a koj, com 67, que também pode designar um 'saco' ou 'bolsa' ou algo que fosse confeccionado a partir de couro cru, incluindo o escudo. Esses termos não designam o escudo de acordo com diferentes tamanhos ou formas, e são freqüentemente intercambiados.

Dentre as 94 vezes em que o a\$pij é mencionado, 4 vezes ele é acompanhado do adjetivo a mfibrothn (II.388-9; XI, 32; XII. 402; e XX, 281) geralmente interpretado como 'que cobre ambos os lados', e que não é empregado à outra forma designativa de escudo. Lorimer (op.cit., p. 189) interpretou esse epíteto como originalmente utilizado para designar o escudo que cobre o corpo inteiro em suas duas formas, 'turriforme' e ' em oito', que aparecem, por exemplo, na adaga da Caça ao Leão (1550-1500 a.C.), proveniente do Túmulo em Poço IV (fig. E1). Ela considera o uso desse adjetivo inapropriado para o escudo redondo (idem).

Por outro lado, o substantivo a \$pij é acompanhado 17 vezes da fórmula pahtos " elsth (III.347, 356; V,300; VII,250; XI, 61, 434; XII, 294; XIII, 157, 160, 405, 803; XVII, 7, 43, 517; XX, 274; XXI, 581; XXIII, 818), que tem uma posição fixa nos versos, cujo sentido de 'igual em todas as direções' é interpretado como designativo da forma redonda por Van Wees (2002, p. 250). Outro epíteto para a \$ pil 
designativo da forma redonda seria eukukl oj, isto é, um escudo 'bem arredondado' (V.453; 797; XII, 426; XIII, 715; XIV, 428). Com exceção de V, 797 que se refere ao escudo de Diomedes, as demais passagens em que tal adjetivo aparece se referem aos escudos dos combatentes em geral.

O adjetivo omf a l oks s a acompanha a \$pij 11 vezes na llíada (IV,448; VI,118; VIII,62; XI,259, 424, 457; XII, 161; XIII, 264; XVI, 214; XIX, 360; XXII, 111) e expressaria a presença de uma única protuberância central (LORIMER, op.cit., p.185) ou de várias protuberâncias como parece haver no escudo de Agamêmnon (XI, 34) e não implicaria na forma arredondada do escudo, podendo o adjetivo ser empregado a qualquer dos tipos. Na passagem VI, 117-18, o escudo de Heitor, que é um a \$pi" olmf a I oes s a, é dito alcançar a sua nuca e o seu pé, característica que dificilmente seria possível para o escudo redondo.

Outra passagem em que o escudo é claramente de corpo inteiro é XV, 645-6 que se refere ao escudo de Perifetes como podhnekhl. O escudo de Ájax (VII, 21920; XI, 485, 527; XVII, 128) é descrito como um sakoj hulte purgon, geralmente interpretado como o 'escudo em torre'.

O segundo termo mais frequente para designar o escudo (s a $k$ oj $)$ aparece associado à expressão mega te stiba roh te (III.335; XVI, 136; XVIII, 478, 609; $X I X, 373)$ que não oferece nenhuma especificação quanto à sua forma.

Na passagem VII, 219-223, o escudo de Ájax é expresso como s a koj, e apresenta sete camadas de couro de boi (ept a bokion) com uma oitava camada de bronze (x a / keon). As referências a camadas sobrepostas de couro constituintes do escudo podem vir em associação tanto ao a $\$ p i j$, como no escudo de Sarpédon (XII, 294-7), no escudo de Heitor (XIII, 803-4) e no escudo de Enéias (XX, 274-276), como ao $s$ a koj, na passagem VII, 21-223 citada acima que se refere ao escudo de Ájax.

As passagens V, 795-8; XI, 38-9; XII, 401-2; XIV, 404-5; XVI, 802-3 e XVIII, 480 sugerem que os escudos eram carregados através de uma alça (t el a mwn) ao redor do ombro. 


\section{Documentação Arqueológica}

\section{Período Micênico}

A ausência de evidência material relativa ao escudo no interior dos Túmulos em Poço de Micenas (1550-1500 a.C.) causa certo estranhamento e esta ausência talvez indique que eles eram confeccionados em material perecível durante este período (LORIMER, op.cit., p. 134). Portanto, evidências de sua forma e material se baseiam apenas nas representações provenientes destes mesmos túmulos, dentre as quais as mais relevantes (menos de uma dúzia) são trabalhos realizados em metal.

\section{Representações}

As representações do período dos Túmulos em Poço mostram dois tipos de escudos de corpo inteiro: o escudo em oito e o turriforme. $\mathrm{O}$ escudo em oito teria origem em Creta (LORIMER, op.cit., p. 137) e teria funções religiosas. ${ }^{18}$ A sua confecção seria em couro cru de boi, pois na maioria das representações desse tipo de escudo as manchas presentes lembram o couro dessa espécie de animal. $O$ escudo turriforme tem um formato retangular cujo perfil lembra a metade de um cilindro e sua origem cretense não é certa (LORIMER, op.cit., p. 137). Na Adaga da Caça ao Leão (fig. ES1), escudos de ambas as formas são mostrados; é interessante perceber como o escudo em oito cobre totalmente a figura humana representada diante do leão. O escudo turriforme nunca é representado com manchas em sua face externa como o escudo em oito, tampouco aparece relacionado a contextos religiosos. Como se pode perceber através das figuras humanas cujos escudos estão às costas, estes estão presos a seus corpos por uma alça cujo termo correspondente em Homero é tel a mw n.

Segundo Lorimer (op.cit., p.153), o escudo de corpo inteiro cessa de aparecer nas figurações em toda a área do Egeu a partir de 1300 a.C.

\footnotetext{
${ }^{18}$ Uma explicação detalhada do escudo em oito pode ser encontrada em Lorimer, 1950, p. 135-7; e sua importância religiosa em Creta é explicada por Evans em The Palace of Minos.
} 
Em Creta, no sítio de Mouliana, um túmulo forneceu dois discos em bronze com $19 \mathrm{~cm}$ cada que estavam num mesmo lárnax juntamente com uma espada também em bronze, datados de c. 1340-1190; presume-se que sejam ônfalos de escudos (fig. ES2), embora tenham sido publicados originalmente como címbalos (SNODGRASS, 1964, p. 39). Apesar de a presença de ônfalos nos escudos não necessariamente implicar em uma forma arredondada, contemporaneamente, um novo tipo de escudo aparece na Hélade Continental, com formato redondo, cujos exemplos são fornecidos por um fragmento proveniente de Micenas (fig. ES3) e outro proveniente de Tirinto (fig. ES4); neste, as duas figuras que seguram o escudo, por sua vez, não se utilizam do tel a nwn. A origem desse novo tipo de escudo é geralmente atribuída ao Oriente Próximo, possivelmente a Anatólia (LORIMER, op.cit., p. 150).

O escudo presente na face A do Vaso dos Guerreiros é um tanto peculiar por se aproximar do escudo redondo, mas apresentar um segmento na sua porção inferior.

\section{Idade do Ferro}

Adentrando a Idade do Ferro, no túmulo 40 de Kaloriziki (Kurion), na ilha de Chipre, foram encontrados fragmentos em bronze acompanhados de três ônfalos (16,2 cm; 8,4 cm e 8,4 cm) também em bronze que foram reconstituídos por Catling (apud SNODGRASS, 1964, p. 39) formando um escudo trapezoidal (fig. ES5); eles estavam acompanhados de uma ponta de lança e uma faca. Snodgrass (1964, p. 58) chama a atenção para a semelhança entre o corte na parte inferior do escudo no Vaso dos Guerreiros e a reentrância na reconstituição do escudo de Kaloriziki.

Do início do Proto-Geométrico (segunda metade do século $\mathrm{XI}$ a.C.) é um ônfalos proveniente do Túmulo 24 do Cerâmico, em Atenas, de $17,4 \mathrm{~cm}$ (SNODGRASS, 1964, p. 39, A8, fig. 3a). O Cerâmico também forneceu mais dois exemplares de ônfalos, mas agora datados do século $X$ a.C., um proveniente do Túmulo 40, com 13,5 cm de diâmetro associado com um machado em ferro (Ibidem, 
A8, fig. 3b) e outro, proveniente do Túmulo $43 \mathrm{com} 11,4 \mathrm{~cm}$ de diâmetro (Ibidem, A9).

O Período Geométrico conta com um exemplar de ônfalos em ferro encontrado em um túmulo no Kynosarges, em Atenas (Ibidem, A26, pl. 21). ${ }^{19}$

O escudo do Dípilon (fig. ES6), em formato de ampulheta, e o escudo Beócio, ambos conhecidos apenas através de representações, são considerados como duas manifestações do mesmo escudo cronologicamente consecutivas. T.B.L. Webster, em um artigo de 1955 (apud AHLBERG-CORNELL, 1992, p. 24), sugeriu que o escudo de Dípilon era, na linguagem iconográfica, como um símbolo heroicizante, não existindo fisicamente mas sendo uma reminiscência no século VIII a.C. do escudo em oito micênico. Ahlberg-Cornell, por outro lado, aponta que a função heroicizante do escudo do Dípilon implicaria em que todas as cenas figurativas do Geométrico que o representassem deveriam estar associadas a uma tradição 'mítica/épica'.

Como se pode perceber, durante a Idade do Ferro, aparentemente os mesmo tipos se conservam (COURBIN, op.cit., p. 80) embora as dimensões tenham diminuído. O escudo do Dípilon corresponderia ao escudo em oito. O escudo em torre do Período do Bronze teria seu correspondente no escudo retangular atestado unicamente pelas representações geométricas ainda assim raras (cf. SNODGRASS, 1964, p. 61). O escudo redondo é atestado pelas representações em vasos desde o final da Idade do Bronze como mostram os dois fragmentos cerâmicos provenientes de Micenas e Tirinto e será o escudo utilizado pelo hoplita.

\section{Conclusão}

A partir dos adjetivos atribuídos aos termos relativos aos escudos, pode-se concluir que há pelos menos duas formas de escudo em Homero (XIV, 371-82; XV, 616): o escudo de corpo inteiro, não sendo possível discernir entre 'turriforme' e 'em oito', talvez com exceção do escudo de Ájax, que é designado como 'em torre' pela

\footnotetext{
19 Outros exemplares existem, mas não foram contabilizados aqui por apresentarem contexto vago ou nenhum contexto. Eles estão listados juntamente com os exemplares supracitados na obra de Snodgrass (1964, p.40-1).
} 
expressão hllthe purgon; e o escudo circular. O couro e o bronze são os materiais mais freqüentemente evocados em associação com o escudo.

Quanto à cultura material, viu-se acima que as três formas de escudo apresentam correspondências ao Período Micênico, embora o tipo redondo tenha sua aparição apenas no final desse período; e as três formas apresentam correspondências ao Período Geométrico, embora o turriforme encontre seu tamanho reduzido e seja muito mais raro na arte Geométrica; e o escudo do Dípilon, que corresponderia ao escudo em oito, também seja de tamanho reduzido não cobrindo o corpo todo do guerreiro. Logo, apesar das semelhanças entre as formas, o escudo de corpo inteiro seria, em Homero, uma reminiscência da Idade Heróica.

\subsection{Armas Ofensivas}

\subsubsection{Espada}

\section{llíada}

Há três termos na llíada que designam "espada": f a $\$$ ga non é o primeiro a aparecer (I, 190); segundo o dicionário grego-francês de Anatole Bailly, o termo de origem obscura se refere a um tipo de facão ou espada. Ele é mencionado 15 vezes por toda a llíada: I, 190; V, 81; VIII, 88; X, 256 e 456; XIV, 405; XV, 713; XVI, 339; XX, 469 e 481; XXI, 19; XXII, 306, 311, XXIII, 807 e 824. O segundo termo a aparecer é cifoj; também mencionado no canto I, 194, quatro versos após o $f a \xi g a n o n$. Embora seja mencionado numa freqüência maior do que of a $\$ g a$ non (42 vezes: I, 194, 210, 220; II, 45; III, 18, 272, 334, 361 e 367; IV, 530; V, 146 e 584; VII, 273 e 303; X, 261; XI, 29, 109 e 146; XII, 190; XIII, 147, 576 e 610; XIV, 26 e 496; XV, 278 e 712; XVI, 135, 332, 333, 337, 340 e 637; XVII, 530 e 731; XIX, 253 e 372; XX, 284, 459, 475 e 476; XXI, 116 e 118), não há indicações textuais de que expressem dois tipos diferentes de espadas. No canto I, por exemplo, quando Aquiles está a ponto de atacar Agamêmnon na ágora, o objeto aparece, no verso 190 , como $f$ a $\$$ ga non e, logo depois no verso 194 , a mesma arma é referida como 
cif oj. Ambos os termos podem vir acompanhados dos adjetivos olu / (pontiagudo) como nos cantos I, 190; XXII, 306 e 311 para of a \$ ga non e IV, 530; XII, 190; XIV, 496; XX, 284; e XXI, 116 para o cifoj. Também podem vir acompanhados do adjetivo mega (grande) como em I, 194 e 220, III, 272, V, 146, XIII, 576-7, XV, 712, XIX, 253 XX, 459 para cif oj e XXII, 306-7 e XXIII, 824-5 para f a $\$$ ga non.

O terceiro e último termo é a pr (V, 509; X, 484, 489; XI, 240, 265, 541; XIV, 385; XV, 256; XVI, 115, 473; XX, 290, 378, 462; XXI, 21, 173, 179, 208). Numa freqüência próxima da de $f a k g a n o n$ (17 vezes), ele é o único a designar uma espada em ouro referida duas vezes como xrus a otou (espada de ouro) de propriedade de Febo Apolo (V, 509 e XV, 256); como os outros dois termos, também pode vir acompanhado do adjetivo mega (XVI, 115), embora ocorra apenas uma única vez, e também a ołu / (XXI, 173), também uma única vez; há duas passagens em que o adjetivo ta nuhkej (pontiagudo) (XIV, 385; XVI, 473) foi utilizado, ao invés de olul.

Certamente of a \$ ga non era uma arma de golpe cortante e nas passagens $\mathrm{V}$, 81; VIII, 88; e X, 456 o verbo a $\$ \mathrm{~s}$ w, que significa cortar com um golpe, está

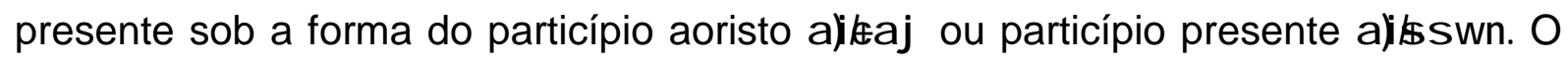
adjetivo a $\mathrm{mf} h \mathrm{hej}$ nos versos $\mathrm{X}, 256$ relacionado ao $\mathrm{f}$ a $\$$ ga non e no $\mathrm{XXI}, 118$ relacionado ao cif oj caracteriza-os como bigumes. Já a br é associado ao verbo pl h\& s w (golpear sem necessariamente cortar) (X, 489; XI, 240, XVI, 115).

Tanto o fasganon quanto o cifoj podem apresentar empunhadura cravejada de prata (f a s ga hon a igur ohl on nos versos XIV, 405 e XXIII, 807; cif oj a gurohI on nos versos II, 45; III, 334 e 361; VII, 303; XIII, 610; XVI, 135; e XIX, 872; no canto I, 219 "a I gur e\$ k w p\$”, cujo significado é "empunhadura de prata", se refere ao mega cifoj do verso seguinte). No canto $X V, 713$, os fa $\$$ ga na dos guerreiros no campo de batalha apresentam belas empunhaduras negras ( $\mathrm{k}$ a l a / 
mel a hdeta kwphenta), que caem de suas mãos e ombros numa bela imagem evocada pelo poeta para expressar as incontáveis mortes no campo de batalha. ${ }^{20}$

Apesar de haver muitas referências ao bronze na llíada como uma metonímia para armas, o termo xa / keoj (bronze) é relacionado especificamente ao cif oj nas passagens do armamento de Páris (III, 334-5); de Pátroclo (XVI, 135-6); e Aquiles (XIX, 372-3); e no canto XXIII, por volta do verso 803, Aquiles conclama os guerreiros que portam armas de bronze cortante (t a mes ik roa xal k oh) a competir pela espada trácia que pertencia a Sarpédon, a quem Pátroclo despojara, e agora Aquiles oferece como prêmio nos jogos fúnebres em honra a Pátroclo. $O$ adjetivo Q rhikion que quer dizer "trácio" ou da Trácia é associado ao fakga non que era, além de trácio, cravejado de prata e kal oh (belo) (XXIII, 807). Este adjetivo (Q rhikion) também aparece relacionado ao cifoj no canto XIII, 576-7, quando Heleno ataca Deípiro com uma grande espada trácia.

Tanto o fakganon quanto o cifoj poderiam ser carregados na bainha (k ol eon: I, 194 e 220; VII, 304-5; XII, 190; XXIII, 824-5) e no "bem cortado boldriê" (ejumh $t \%$ tel a mw nos versos VII, 303-4; XXIII, 824-5). No I, 190 Aquiles puxa o

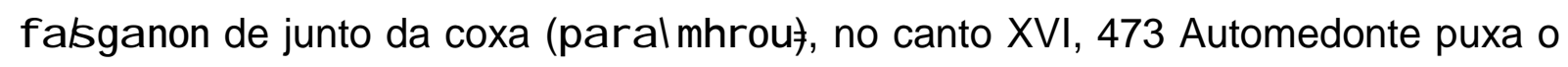
a br de junto da coxa, e no XXI, 173, a única ocorrência de a łr ołul, também é retirada de junto da coxa por Aquiles; no canto XXII, 307 Heitor a puxa do flanco (upoll a pathn); no canto II, 45 Agamêmnon a lança aos ombros para ir se reunir aos outros chefes na ágora (a mf ild" a l" whois in bal eto cif oj a rgurohlon), fórmula que será repetida no canto III, 334-5.

Nestas passagens do canto I, 190 e II, 45 ambos, Aquiles e Agamêmnon indicam que as espadas também eram carregadas fora do campo de batalha, pois ambos as portam durante uma reunião entre aliados na ágora.

\footnotetext{
${ }^{20}$ As espadas de empunhadura prateada ou cravejada de prata me parecem ser privilégio dos heróis, pois nas cenas em que aparece a massa de guerreiros portando espadas elas são de empunhadura negra como referido acima ou de boa empunhadura como se pode verificar nas duas passagens XVI, 332 e XX, 475 onde há a presença do adjetivo k w phent i.
} 
Há duas passagens em que a espada se parte durante o combate; no canto III entre os versos 360-370 ao atacar Páris, a espada de Menelau se parte; e no canto XVI, 338-9, Lícon ao atacar Peneleu tem a lâmina de sua espada quebrada perto do punho.

\section{Documentação Arqueológica}

\section{Período Micênico}

As mais antigas espadas encontradas no continente são provenientes dos Túmulos em Poço em ambos os Círculos Tumulares de Micenas (fig. ESP1) (SANDARS, 1961, p. 17). O número de espadas que foram encontradas apenas no interior do Círculo Tumular A chegou a 150 exemplares, as quais Karo ${ }^{21}$ classificou em dois tipos, $A$ e $B$ (fig. ESP2):

- As do tipo A (Sandars, 1961, pl. 17:1-3) são bastante longas, chegando a ultrapassar $1 \mathrm{~m}$ de comprimento, com espiga achatada e estreita que pode ser curta, apresentando apenas um rebite, ou mais longa, com até três rebites; os ombros são arredondados e sem flanges; apresenta na lâmina dois orifícios de rebite uns três centímetros abaixo do ombro; e a lâmina tem uma nervura central rombóide, ou ocasionalmente arredondada, bastante pronunciada e abrupta, exceto em alguns raros casos, quando apresenta uma decoração mais elaborada. De origem cretense, as espadas do tipo A apresentam uma fraqueza no cabo, pois a espiga é freqüentemente encontrada partida e provavelmente deixava o guerreiro desarmado apenas com o cabo na mão (as passagens da llíada III, 360-370 e XVI, 338-9 fazem menção à quebra das espadas durante a batalha). Algumas espadas do tipo $A$ apresentam uma empunhadura em forma de chifre, o que protegeria a mão do guerreiro em caso de quebra durante o combate; tal empunhadura poderia ser de marfim, faiança ou alguma pedra semi-preciosa, e era anexada por meio de rebites à extremidade inferior da lâmina e ao cabo.

- As do tipo $B$, encontradas em menor número do que as do tipo $A$, são mais curtas e robustas, com espiga, que pode apresentar flanges, mais longa e larga e com

\footnotetext{
${ }^{21}$ Karo, G. Schachtgraber von Mykenai (1930-33) 200-06 (apud Sandars, p. 17).
} 
vários orifícios de rebites; elas têm ombros retilíneos e com flanges suavemente pontudos, com rebites dispostos horizontalmente na lâmina imediatamente abaixo dos ombros; a nervura central é também abrupta como nas do tipo $\mathrm{A}$, mas não tão pronunciada (Sandars, 1961, pl. 18:5). Seriam uma criação exclusivamente micênica. A espiga com flanges as tornava menos vulneráveis à quebra, mas a grande dimensão dos buracos dos rebites não as impossibilitava de partir.

Esses dois tipos de espada, A e B, datam da segunda metade do século XVI a.C. e nenhum dos dois seria utilizado com a finalidade de corte, mas apenas de perfuração, diferentemente da espada em Homero como visto acima.

Durante o século $\mathrm{XV}$, dois novos modelos foram criados a partir dos modelos $A$ e $B$ numa tentativa de corrigir suas fraquezas. $O$ resultado foi uma espada bigume com nervura mediana pronunciada, cujo cabo e lâmina são forjados como uma única eça, que Sandars classifica como tipos C e D (Sandars, 1963, p. 119-125):

- O tipo C diferencia-se pouco do tipo A; apresenta uma lâmina mais delgada, mas ainda com uma nervura mediana pronunciada, e uma proteção para as mãos em forma de chifre que não é mais fabricada em separado e depois anexada, mas é moldada junto com a lâmina e a espiga; esta recebeu flanges como nas espadas do tipo $B$; elas eram longas, mas nunca chegavam a ter o mesmo comprimento das espadas do tipo A. Assim, o metal foi distribuído melhor e suas empunhaduras eram mais eficientes.

- $O$ tipo $D$ era mais modesto que o tipo $C$, mais curta e mais comum também, e sua principal diferença residia na proteção para as mãos, que era cruciforme e não exatamente com "chifres".

Após o Período Palacial, as grandes espadas adornadas dos séculos XVI e $\mathrm{XV}$ desaparecem e passam a ser mais curtas, sendo difíceis de diferenciar das adagas.

\section{Linear B}

$\mathrm{Na}$ ala doméstica do palácio de Cnossos foram encontrados 22 tabletes em Linear B que apresentam o ideograma para "espada". Como o ideograma é um tanto 
esquemático há dúvidas se eles representam espadas ou se representam adagas. $\mathrm{O}$ grupo de sinais encontrados ao lado desses ideogramas tem sido interpretado pelos decifradores como uma forma da palavra "phasgana" (fig. ESP3).

\section{Idade do Ferro}

Pouco antes do fim da Idade do Bronze (c. 1200 a.C.), um tipo de espada conhecida pela sua classificação em alemão como 'Griffzungenschwert', ou "Naue Tipo II", tinha se tornado muito comum em várias partes da Europa além do Egeu. Aceita-se que ela tenha se desenvolvido na Hungria ou Europa Central, embora a maioria dos exemplares encontrados na Grécia seja de fabricação local. O fato de essas espadas terem sido encontradas na Grécia antes da queda de Micenas sugere que eles a tenham adotado. E antes mesmo do fim da Idade do Bronze, elas passaram a ser fabricadas em ferro (SNODGRASS, 1967, pp. 28-9). Esse tipo de espada, diferentemente das anteriores, que se diferenciavam mais pelas características do cabo ou da espiga, apresenta uma lâmina bastante particular com suas laterais correndo em paralelo pelo comprimento até que se fecham para confluir numa ponta bastante aguda. ${ }^{22}$

Durante o período Proto-Geométrico (meados do $\mathrm{XI}$ até fim do $\mathrm{X}$ ), as espadas são de ferro e do modelo 'Naue Tipo II' (Ibidem, p. 36-37). Algumas delas são bastante longas e eram muito grandes para serem enterradas junto com seus donos nos pequenos túmulos da época, pois os mortos eram cremados nesse período. Eventualmente elas eram dobradas na forma de $U$ para serem enterradas com seus proprietários.

Durante o Período Geométrico (séc. IX e VIII) a espada se torna curta e extremamente robusta. $\mathrm{O}$ pomo era de forma semi-lunar como aqueles que se podem observar na cerâmica geométrica do século VIII. Embora a precisão dessas representações seja questionável, pois o artista tem de lidar com a quantidade de espaço disponível num vaso, as representações de homens armados na ânfora do

\footnotetext{
${ }^{22}$ Snodgrass (1964) fornece uma lista bastante completa de exemplares desse tipo de espada.
} 
Dípilon mostram uma espada curta com um pomo semi-lunar, freqüentemente acompanhada por uma adaga.

\section{Conclusão}

Apesar de existir um único exemplar proveniente do Túmulo em Poço $\mathrm{V}$ do Círculo Tumular A em Micenas que seja uma espada de perfuração e corte, esse tipo de espada apenas se tornaria mais comum na área do Egeu a partir de 1200 a.C., logo, as grandes espadas tipos $A$ a $D$ não correspondem ao tipo de espada utilizado pelo guerreiro homérico. Snodgrass (1964, p. 94 e ss.) sugere que a substituição do bronze pelo ferro como o metal para a lâmina das espadas teve início no final do Período Micênico (Ibidem, p. 103) e que os primeiros exemplares em ferro apresentam poucas diferenças tipológicas em relação às suas antecessoras em bronze, mas a partir da adoção do ferro as espadas seguiram uma tendência à diminuição do comprimento da lâmina (Ibidem, p.113).

Homero não menciona sequer uma espada em ferro, como visto anteriormente, embora as evidências arqueológicas mostrem que apenas 4 exemplares em bronze foram encontrados entre os séculos XI e VIII a.C. na área do Egeu e mais de $55 \mathrm{em}$ ferro foram estudados e catalogados (Ibidem, p. 174). Isso nos levaria a concluir que as espadas em Homero seriam uma reminiscência da Idade do Bronze, não fosse o uso da espada em Homero, que está em discordância com o tipo de espada que era mais comumente forjada para tal período, uma espada destinada a perfuração e não ao corte. Embora não haja distinção de uso dos três termos para 'espada' em Homero, certamente os três termos designam espadas cortantes.

Com o material característico do Período Micênico e a utilização própria do Período Pós-Micênico, as espadas não podem ser consideradas como elementos caracterizadores de qualquer desses estratos; ao contrário, parece haver aí uma mistura de ambos no mesmo objeto. 


\subsubsection{Lança e Dardo}

\section{Ilíada}

Como as espadas, as lanças compõem outro elemento do armamento ofensivo do guerreiro na llíada.

A espada é mencionada 74 vezes na llíada (15 como f a \$ ga non, 42 como cif oj e 17 vezes como a \pr); já, a lança é mencionada em torno de 3 vezes esse número, juntando-se as ocorrências de douri/ou doru/ou, ainda, elyoj ou egx eith. Em decorrência dessa freqüência, Lorimer (op.cit., p. 258) considera a lança a arma do herói homérico por excelência. De 206 vezes que alguém utiliza uma arma na Ilíada, 166 vezes são lanças (80,5\%), das quais 87 vezes são arremessos e 79 vezes são combates próximos (VAN WEES, 2004, p. 251).

Os termos egxes pal oj (II, 131; XIV, 449; XV, 605) e egxes imwtoj (II, 692, 840; VII, 134), dourikI utol ou dourikl eitol (II, 645, 650; II, 657; V, 45, 55, 72; X, 109, 230; XI, 333, 368, 396, 401; XIII, 210, 467, 476; XVI, 26, 472, 619; e XXI, 233) são utilizados para exprimir a habilidade do guerreiro no manejo da lança, mas não caracterizam especialmente os aqueus ou os troianos, como as cnêmides.

O uso de um par de lanças pelo guerreiro é atestado pelas passagens: III, 18 (Páris); XI, 43 (Agamêmnon); XII, 298 (Sarpédon); XIII, 241 (Idomeneu); XVI, 139 (Pátroclo); XXI, 145 (Aquiles).

Os epítetos mais freqüentes para a lança são ma k r ol (III, 135, 137, 254; etc) (mais associado a e $\times 0$ j ou egx eih); ołu/(IV, 490; V, 238; etc.), também usado para as espadas; e f a einol (IV, 496; V, 611; etc). a mf iguon ocorre apenas com egx oj e somente no dativo plural. Esse epíteto é de difícil compreensão: pode ser 'com duas pontas', no caso, uma em cada extremidade da lança, ou com uma 'ponta de dois gumes' do tipo foliforme (LORIMER, op.cit., p. 261).

Não há menção a lanças com ponta de ferro, e quando o metal é mencionado, ele é o bronze (III, 18; V, 145; etc.).

A distinção entre lança de combate próximo e lança de arremesso não é passível de ser feita com base na nomenclatura presente na épica. 


\section{Documentação Arqueológica}

\section{Período Micênico}

Segundo Lorimer (op.cit., p. 255) e Courbin (op.cit., p. 71), a lança micênica surge como uma arma de combate próximo, não sendo utilizada como uma lança de arremesso, pois, a inferir de suas pontas, a lança teria um comprimento e um peso inapropriados para serem arremessadas. Os mais antigos exemplares no continente são provenientes dos Túmulos em Poço em Micenas (século XVI a.C.) (fig. LD1) (LORIMER, op.cit., p. 254 e fig. 30). Outros exemplares também são conhecidos de Dendra, de Cnossos (COURBIN, op.cit., pl. 2:1), de Pilos (c. 1400 a.C.), e de Kallithea (c. 1200-1100 a.C.) (Ibidem, pl. 2:2, 3). ${ }^{23}$

A maior parte dessas pontas de lanças apresenta lâmina foliforme com uma nervura central bastante pronunciada, como as espadas dos tipos A e B, contemporâneas a ela, e é provida de um soquete longo que termina num anel anexado a ele ( $p$ of k hj , Ilíada, VI, 319-20; VIII, 495). O soquete (k a ul ol, Ilíada, XIII, 162, 608; XVI, 115; XVII, 607) era confeccionado a partir da extensão da lâmina e formava com ela uma única peça; o metal era batido em torno a um mandril até obter a forma de um cilindro, em cuja extremidade era anexado o p of $\mathrm{khj}$.

No Túmulo II de Kallithea há um exemplar dotado de um aparato para a extremidade inferior da lança, e tem sido interpretado como o s a urwthr (llíada, X, 153) (COURBIN, op.cit., pl. 2:3) ou our ía x oj (llíada, XIII, 443; XVI, 612; XVII, 528).

A Estela dos Guerreiros e o Vaso dos Guerreiros apresentam figurações bastante próximas dos exemplares citados acima.

\section{Idade do Ferro}

O ferro substituiu o bronze um pouco tardiamente em relação às espadas, mas, a partir do século XI a.C., seu uso passaria a ser generalizado durante o

\footnotetext{
${ }^{23}$ Para o exemplar de Dendra cf. BCH 85, 1961, p. 672; 86, 1962, p.749 e para o exemplar de Pilos cf. BCH 80, 1956, p. 283 fig. 9.
} 
Geométrico. Courbin (op.cit, p. 72) associa o emprego do ferro a uma mudança na forma: o aparecimento da lança de arremesso ou dardo entre o final do ProtoGeométrico e início do Geométrico.

Os vasos do Período Geométrico mostram o uso de duas até mesmo três lanças por guerreiro. Lorimer (op.cit., p. 254) e Snodgrass (1964, p. 137) concordam quanto ao uso prevalecente de lanças de arremesso durante o Geométrico.

\section{Conclusão}

Embora as lanças sejam muito mais freqüentes na llíada do que as espadas, o número de pontas de lanças datadas do Período Micênico, principalmente no que concerne os Túmulos em Poço, é muito menor do que o das espadas.

O problema da distinção entre a lança de arremesso e a lança de combate próximo continua em solução, mas o uso das lanças de arremesso, embora não fosse desconhecido dos micênios, não se tornaria prevalecente até o início do Geométrico (SNODGRASS, 1964, p. 138-9). Snodgrass (idem, p. 174) demonstrou que o uso de uma única lança de combate próximo não fora adotada na fase inicial da constituição do armamento hoplítico e que o seu uso se tornara escasso desde o princípio do Período Geométrico; logo, a sua utilização em Homero seria uma reminiscência da tradição da Idade do Bronze. Em contrapartida, o uso da lança de arremesso ou dardo parece ser um traço posterior à Idade do Bronze.

Muito similarmente às espadas na llíada, as lanças parecem misturar as reminiscências do Período Micênico, onde o bronze é o metal utilizado, com o uso corrente ao menos do Período Geométrico, durante o qual tanto a lança de combate próximo quanto o dardo são utilizados paralelamente.

4.2.3 0 arco e a flecha

\section{llíada}


O arco na llíada é referido por dois termos tokon (II, 718, 720, 775, 827; III, 17, etc.) e bi ol (IV, 125; etc). A flecha é referida pelos termos ols t ol (IV, 118, 125, 134, etc.) e i

Os adjetivos a gkul oj (curvado, V, 209; etc), ka mpul oj (curvado, III, 17) e palihtonoj (curvado para trás, VIII, 266) estão associados ao arco composto segundo Lorimer (op. cit., p. 289).

$\mathrm{Na}$ Ilíada os arqueiros parecem não lutar numa posição avançada, mas atirar suas flechas ao longe e atrás das linhas de frente (Ilíada, XIII, 721); as flechas são também disparadas no início da batalha antes da luta corpo a corpo ser iniciada (Ilíada, XV, 312-314). O arco é freqüentemente associado e usado pela massa de guerreiros como os guerreiros de Filoctetes (II, 716-20) ou os Lócridas liderados por Ájax Oileu, do lado dos aqueus. Do lado troiano, o arco é usado pelos Cários e pelos Lícios.

Dentre os guerreiros singulares que manuseiam o arco e a flecha estão: Filoctetes que é caracterizado no Catálogo das Naus como um arqueiro exímio

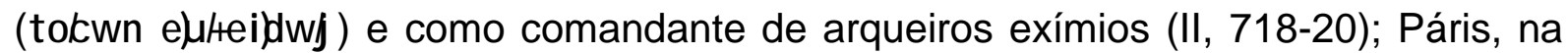
sua primeira aparição, porta, além da espada e de um par de dardos, o arco (III, 1520); Pândaro (II, 827; IV, 105 e ss.) que recebeu seu arco de Apolo; Teucro, VIII, 266-274, que também o recebeu de Apolo (XV, 441). O arco de Pândaro (IV, 105$111)$ é descrito como composto de chifres de bode, com 16 palmos de comprimento e polido por um artesão, que colocou ponteiras de ouro nas extremidades. Sabe-se também pelo texto homérico que a ponta da flecha de Pândaro é de ferro (IV, 123).

A passagem VIII, 266-274 descreve Teucro utilizando o arco e sendo flanqueado por Ájax Telamônio com seu escudo; essa descrição do arqueiro protegido por um outro guerreiro que porta um escudo lembra a cena que figura na Adaga da Caça aos Leões (prancha escudo, fig. ES1). 


\section{Documentação Arqueológica}

\section{Período Micênico}

Como nunca um arco foi encontrado na Hélade, a evidência arqueológica para a sua utilização é composta pelas pontas de flechas e pelas representações.

Os exemplares de pontas de flechas com os quais a arqueologia conta são, em sua grande maioria, provenientes de depósitos em santuários ou de coleções de museus geralmente coletados na superfície e, portanto, não são passíveis de serem datados estratigraficamente (SNODGRASS, 1964, p. 141). Raramente são encontradas pontas de flechas em enterramentos, o que nos faz concluir que não era costume enterrá-las junto com as outras armas.

Pontas em obsidiana (provavelmente importadas de Melos) e algumas em sílex foram encontradas no Túmulo em Poço IV e em alguns Túmulos em Câmara em Micenas, em outros sítios como Prosymna, Dendra e Cnossos (LORIMER, op.cit., p. 278). Como sílex era raro na Hélade e de qualidade inferior, Lorimer (idem) sugere que elas eram importadas do Egito.

Durante o Heládico Recente III pontas em bronze ocorrem em alguns poucos sítios (COURBIN, op.cit., p. 73), mas não há evidências de que fossem usadas com finalidades bélicas, apenas para a caça (LORIMER, op.cit., p. 278).

No Palácio de Cnossos, dois depósitos de pontas de flechas em bronze foram descobertos nas adjacências de onde se encontraram tabletes de inventários que continham o símbolo para ponta de flecha (Ibidem, p. 279).

A existência de diferentes tipos de arcos desde o Período Micênico até o Geométrico é detalhadamente exposta por Lorimer (op.cit., p. 276-289): o arco simples, o arco composto de curvatura única e o arco composto de dupla curvatura (que Lorimer identifica com o arco cita). $\mathrm{O}$ arco simples (amiúde também referido como 'europeu') é conhecido durante a Idade do Bronze na Europa e em Creta e o composto somente em Creta (SNODGRASS,1964, p. 142).

Durante a Idade do Bronze, o arco raramente aparece nos monumentos do continente ou de Creta. Ele pode ser visto em cenas de caça em dois achados micênicos: um anel de ouro proveniente do Túmulo em Poço IV (fig. AF1) e na 
Adaga da Caça ao Leão (prancha escudo, fig. ES1). Em ambos os casos eles são do tipo simples e não composto.

\section{Linear B}

Em um tablete de Pilos em que há uma lista de trabalhadores do palácio, fabricantes de arcos são citados como to-ko-so-wo-ko. Em um tablete de Cnossos (KN R 4482), 6010 flechas são indicadas.

\section{Idade do Ferro}

Os exemplares do Proto-Geométrico são extremamente raros no continente e não são mais em bronze, mas em ferro (COURBIN, op.cit., p. 73). A julgar a ausência de pontas de flechas na Grécia Continental no Proto-Geométrico e no Geométrico, a arquearia teria sofrido um longo eclipse durante tais períodos e seria re-introduzida mais tarde (ver prancha escudo, fig. ES6). Segundo Snodgrass (1964, p.144) é difícil datar essa re-introdução do arco no continente. Em Creta, a evidência atesta a continuidade de uso do arco composto de curvatura única desde o Minóico até o Período Orientalizante.

\section{Conclusão}

Há indicações de que apenas no século VII é que o arco composto começou a tomar o lugar do arco 'europeu' no continente. Quando isso aconteceu, foi apenas na forma com curvatura única, que teve continuidade em Creta desde os tempos minóicos. É com esse tipo que Lorimer identifica a maioria das descrições homéricas e, como não há evidências conclusivas de outro tipo de arco composto, essa identificação é em geral aceita. Portanto, se o arco homérico é derivado da Idade do Bronze ou da Idade do Ferro, a influência de Creta deve ter sido o pano de fundo. A ponta de flecha de ferro de Pândaro, um lício, não precisaria ser um elemento recente se ele representa uma prática da Anatólia, pois exemplos nesse material 
ocorrem em sítios na Anatólia desde o início da Idade do Ferro, ou seja, o século XI a.C.

\subsubsection{Carro}

O carro talvez seja o elemento mais complexo dentre as armas a ser analisado. ${ }^{24}$ Ele não é uma arma em si, mas um meio de transporte que pode ser utilizado em combate em associação com outras armas como a espada, a lança e o arco para o ataque, e o escudo para a defesa.

Além de pressupor a domesticação do cavalo, o seu uso em combate também pressupõe um domínio pleno das técnicas de condução. O estudo do carro também inclui a análise de suas partes constituintes, bem como o emprego de dois (biga) ou quatro cavalos (quadriga).

Como o interesse aqui é o estudo do carro relacionado ao combate, as cenas de caça ou de procissão em que ele figura não farão parte do estudo.

\section{llíada}

Na llíada, os carros (dif roi, sing. difroj, llíada, X, 305) não são usados exclusivamente como parte do cortejo fúnebre de um herói morto, como nos funerais de Pátroclo (ver capítulo 3), mas também são usados como um meio de transporte para se dirigir ou se retirar do campo de batalha. Seu uso em combate é aludido em apenas duas passagens (IV, 293-309 e XI, 150-1).

No canto IV (v. 293-309), Nestor, guiando os guerreiros à luta, dá algumas indicações da tática para o uso do carro em combate. Ele indica que os carros devem se manter em fila sem permanecer numa posição avançada nem retroceder, e os guerreiros que estão montados nesses carros são recomendados a lutar com a lança (êj $\times$ oj). A partir dessa passagem e de outra em que Pândaro (V, 280), montado num carro durante uma batalha, abandona seu arco em detrimento de uma lança, parece sugerir que esta era a arma mais indicada em Homero para um

\footnotetext{
${ }^{24}$ Por esse motivo, ele merecerá um estudo à parte; aqui, apenas exporei o tema em linhas gerais.
} 
combate sobre um carro, uma prática semelhante à dos hititas, que se utilizavam de uma lança de combate próximo em entraves sobre carros, mas diferente da dos egípcios que preferiam o arco (LORIMER, op.cit., p. 324). Essa prática da arqueria sobre o carro não está presente em Homero. Também não há menção em Homero da utilização do escudo sobre o carro.

Embora a passagem $\mathrm{XI}, 150-1$ sugira um confronto entre dois carros, o uso mais corrente do carro em Homero parece ser o de possibilitar ao combatente se aproximar ou se distanciar do oponente de maneira mais rápida.

Descrições do carro em Homero são praticamente ausentes, a não ser por algumas passagens nas quais a decoração é em bronze (IV, 226 e X, 393 por exemplo) ou em ouro e prata como o carro de Resus, rei trácio (X,438). Homero também não dá qualquer descrição da posição do eixo do carro ou da utilização de quatro cavalos (quadriga) ao invés de dois (biga); embora a passagem XI, 699 cite quatro cavalos, não há menção explícita de que os quatro cavalos compusessem uma quadriga.

\section{Documentação Material}

\section{Período Micênico}

\section{Representações}

A existência do carro durante o Período Micênico e sua utilização para combate são atestadas desde o século XVI a.C. embora apenas por representações em alguns dos achados provenientes dos Túmulos em Poço do Círculo Tumular A, como três estelas funerárias (figs. CA1, CA2 e CA3) e um anel sinete de ouro (fig. AF1), e uma miniatura encontrada na Tessália datada do século XIII a.C. (fig. CA4). ${ }^{25}$

Nas três estelas o carro é representado sobre a roda, que apresenta quatro raios; a segunda roda ou um segundo cavalo não são indicados nessas representações, embora o esquema de representação em perfil pressuponha a existência da roda do outro lado do carro. Também proveniente deste túmulo é um

\footnotetext{
${ }^{25}$ Há representações de carros em afrescos de Tirinto e Pilos, mas as cenas em que eles figuram não são cenas de combate ou caça, mas prováveis cenas de cortejo.
} 
anel de ouro, cujo entalhe representa duas figuras masculinas sobre um carro, sendo uma delas um arqueiro, perseguindo um cervídeo (fig. AF1); embora esta seja uma cena de caça e não de combate, neste anel sinete, apesar de a técnica ser a de representação em perfil, a mesma empregada nas estelas, o artesão mostra a utilização de dois cavalos (biga), mas omite a presença dos arreios. Ainda que nas três estelas os carros estejam sendo usados com a finalidade de combate, a maior parte das representações de carros do Período Micênico compõem cenas de caça ou cortejo, como aquela que figura no anel da fig. AF1. Infelizmente essas representações contribuem muito pouco para o estudo da estrutura do carro.

Em relação ao uso de outras armas associados ao carro, a estela da figura CA1 pouco contribui por causa de seu estado bastante danificado, embora possa ser notada uma figura prostrada sob um escudo em oito entre o cavalo atrelado ao carro e o leão e o cervídeo representados abaixo. Na estela da figura CA2, uma espada pode ser observada nas mãos de ambos os oponentes. Na figura CA3 não é possível ver se o condutor do carro está armado, mas a figura diante do cavalo parece estar em posição de ataque empunhando uma lança.

O uso da lança ou do arco em combate sobre carros parece ser mais apropriado do que a espada, pois são armas de alcance mais longo do que a espada, que exige uma aproximação maior do oponente para desferir o golpe.

A miniatura proveniente de Tirinto (fig. CA4), embora não esteja associada diretamente ao combate, fornece uma visualização tridimensional, a partir da qual é possível perceber os cavalos jungidos e o eixo central que corre do jugo ao carro.

\section{Linear B}

Há tabletes em Linear B provenientes de Cnossos que aparentemente contêm um inventário de cavalos e carros (fig. CA5) (LORIMER, op.cit., p. 314, fig. 43). 
A documentação para a existência ou utilização do carro é ausente desde o final do Período Micênico até o Geométrico Recente, quando ele reaparece. Um exemplar foi encontrado num túmulo de Salamina de Chipre (KARAGEORGHIS, 1963, p. 373-380) e data entre o final do século VIII e o início do VII a.C.

Há também as miniaturas de carros e as representações vasculares, como em alguns vasos do Dípilon (ver cap. 3, figs. 2 e 3), que são mais numerosas (COURBIN, op.cit., p. 74).

\section{Conclusão}

Lorimer (op.cit, p. 307) sugere que o carro é um dos poucos elementos da cultura material a ter persistido sem grandes mudanças desde o século XVI a.C. até o período Clássico. Snodgrass (1964, p. 159), em contrapartida, observa que a ausência de evidência durante os séculos que vão desde o final do Heládico Recente III até o final do século VIII a.C. não permite assumir qualquer continuidade entre os carros micênicos e os do Período Geométrico, embora algumas características dos carros do Período Geométrico sejam mantidas em relação aos carros do Período Micênico, como a roda de quatro raios e a posição central do eixo.

O emprego de quatro cavalos (quadriga) para a condução dos carros, ao invés de dois (biga), como era a prática micênica, é indicado por alguns vasos do Geométrico, mas o início dessa prática ainda não foi determinado em termos cronológicos.

\subsection{Considerações Finais}

O estudo das armas na llíada mostra que algumas características da cultura material da Idade do Bronze estão indubitavelmente preservadas no poema, mas elas são muito menos numerosas e certas do que se acredita. A visão de que a cultura retratada nos poemas homéricos é a cultura da Idade do Bronze era um 
resultado inevitável do sucesso das escavações de Schliemann e Tsountas. Tal exagero não foi passível de uma revisão crítica e eficaz até a construção de uma cronologia perspicaz, para a qual as escavações de Evans em Cnossos foram fundamentais, a revelação de que os Túmulos em Poço precederam a destruição de Tróia Vlla em alguns séculos, e a noção de que metade de um milênio separa o Vaso dos Guerreiros e as representações de cenas de batalhas em cerâmica do final do Geométrico.

Enquanto o escudo de corpo inteiro, o elmo de presas de javali e as espadas com cravos de ouro e prata são 'micenismos' em Homero (sem mencionar a maior ocorrência de armas de bronze do que de ferro), ${ }^{26}$ o uso de um par de lanças ou dardos ao invés de uma única lança, como era a prática micênica, é um elemento do Geométrico.

A imagem da grande "colcha de retalhos" à qual se evoca amiúde para se referir à obra homérica é pertinente quando se trata da mistura de elementos de épocas diferentes numa mesma trama poética. Homero juntou esses retalhos e os costurou com tal primazia que somente com o surgimento da Arqueologia é que foi possível diferenciar um pouco dos seus elementos constitutivos no tocante a essas épocas. O estudo da cultura material não constitui em desmanchar essa colcha atirando seus retalhos ao léu, mas perceber onde estão os remendos tão bem cosidos pelo poeta e ressaltar sua característica "dedálea", que provavelmente a audiência de Homero podia reconhecer, assim tentando aproximar o leitor moderno dessa audiência original.

\footnotetext{
${ }^{26}$ Homero usa quase que exclusivamente o bronze para as armas. Snodgrass (1964, p. 260) apresenta uma tabela apenas para as espadas e lanças da região do Egeu datadas entre 1100-700 a.C., ou seja, da Idade do Ferro. Os dados dessa tabela mostram que nenhuma espada ou ponta de lança é referida como sendo de ferro em Homero e que os achados arqueológicos para tal período revelaram 4 espadas de bronze contra mais de 55 em ferro e 13 pontas de lanças em bronze contra mais de 53 pontas de lanças em ferro.
} 


\section{Objetos relacionados}

\section{Prancha Cnêmides}

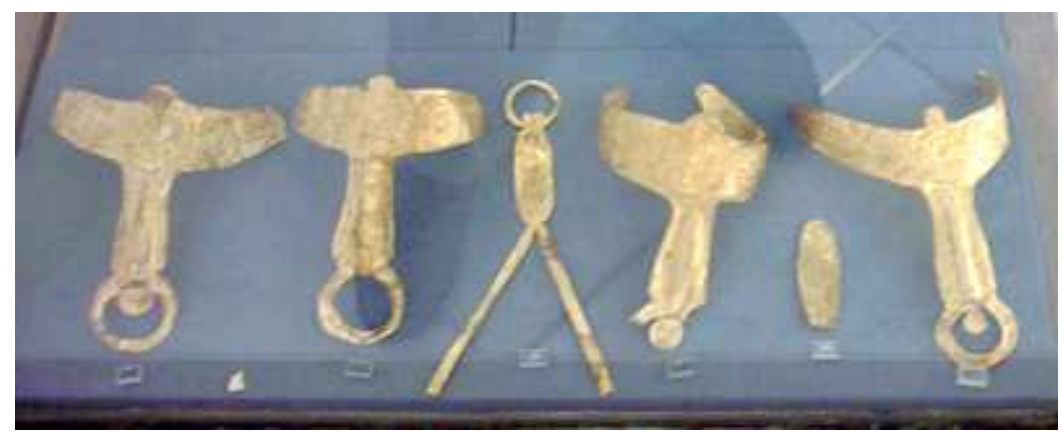

Fig. C1 Possíveis fivelas para segurar cnêmides, provenientes do Círculo Tumular A, encontradas por Schliemann durante a campanha de escavação em 1876. Cerca de 1550-1500 a.C. Fonte da figura: $<$ http://www.salimbeti.com/micenei/armour4.htm>. Último acesso em 11/04/2008.

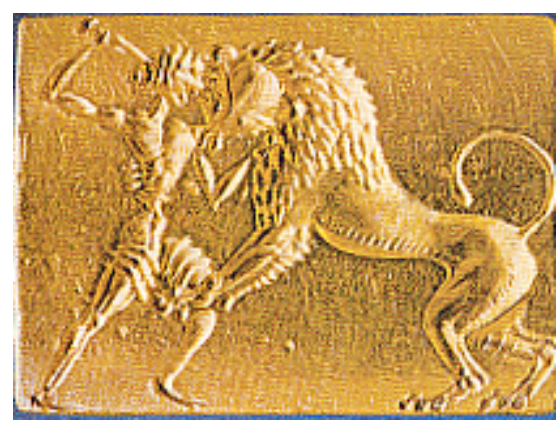

Fig. C2 Ornamento de ouro entalhado com figura humana usando uma espécie de calção. Encontrado por Schliemann no interior do sepulcro III do Círculo Tumular A durante a campanha de escavação de 1876. Cerca de 1550-1500 a.C. Fonte da figura: $<$ http://www.salimbeti.com/micenei/armour4.htm $>$. Último acesso em 11/04/2008.
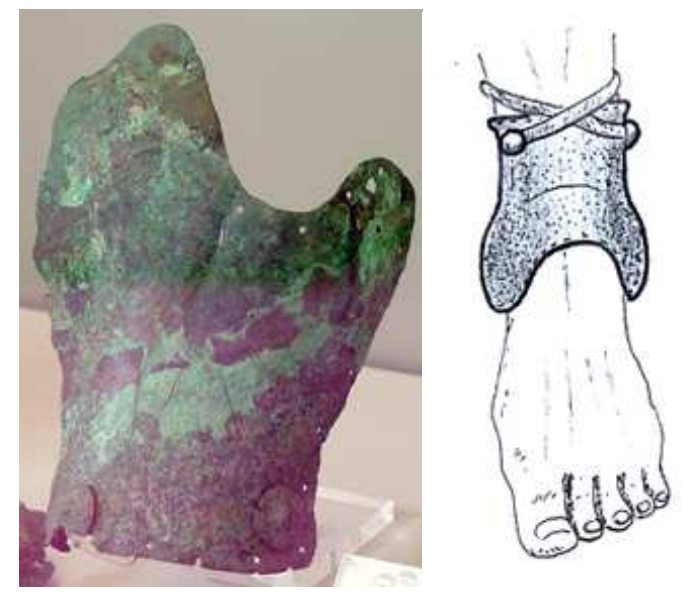

Fig. C3 Objeto de bronze, provável tornozeleira, encontrado na Câmara Tumular 15, em Micenas. Cerca de 1300-1250 a.C. Fonte da figura: <http://www.salimbeti.com/micenei/armour4.htm>. Último acesso em 11/04/2008. 


\section{Exemplares}

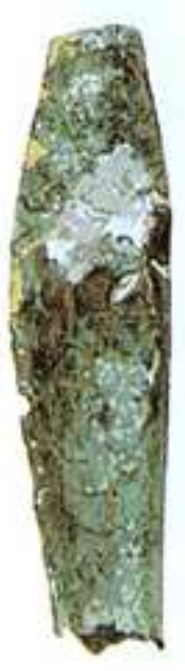

Esquerda:

Fig. C4 Cnêmide

de bronze

encontrada no

interior do Túmulo

12 em Dendra, em

1960. Cerca de

1400 a.C. Fonte

da figura:

$<$ http://www.salimb

eti.com/micenei/ar

mour4.htm>

Último acesso em

11/04/2008.
Direita:

Fig. C5 Cnêmide

de bronze

encontrada em

Olímpia. Século VI

a.C. $37 \mathrm{~cm}$ de

altura. Fonte da

figura:

$<$ http://ccwf.cc.ute

xas.edu/ warfare/

Lectures//mages/2

9/04\%20archaic

greave olympia.J

PG>. Último

acesso em

11/04/2008.

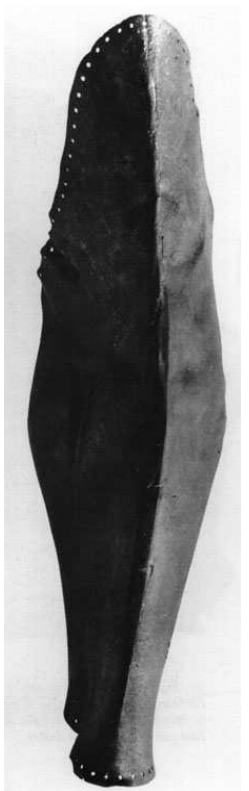

29. Bronze greave of archaic type from
Olympia. Height $37 \mathrm{~cm}$. Sixth century.

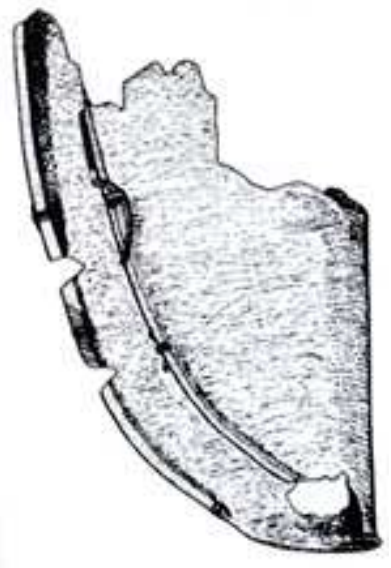

Fig. C6 Representação de fragmento de cnêmide encontrada no Túmulo "Sueco" $18 \mathrm{em}$ Enkomi, Chipre, datado de cerca de 1200 a.C. Fonte da figura:

$<$ http://www.salimbeti.c om/micenei/armour4.ht m $>$. Último acesso em $11 / 04 / 2008$.

\section{Direita:}

Fig. C7 Fragmentos de cnêmides provenientes de Enkomi, Chipre, datadas de pouco depois de. 1200 a.C. Fonte da Figura: $<$ http://www.salimbeti.co $\mathrm{m} /$ micenei/armour4.htm > . Último acesso em 11/04/2008.

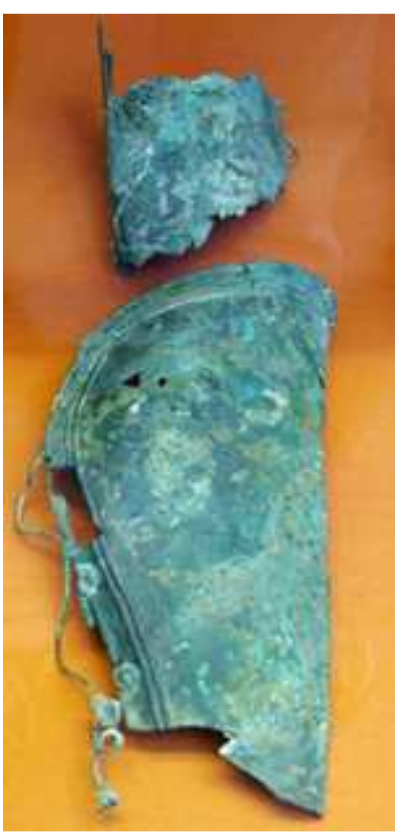




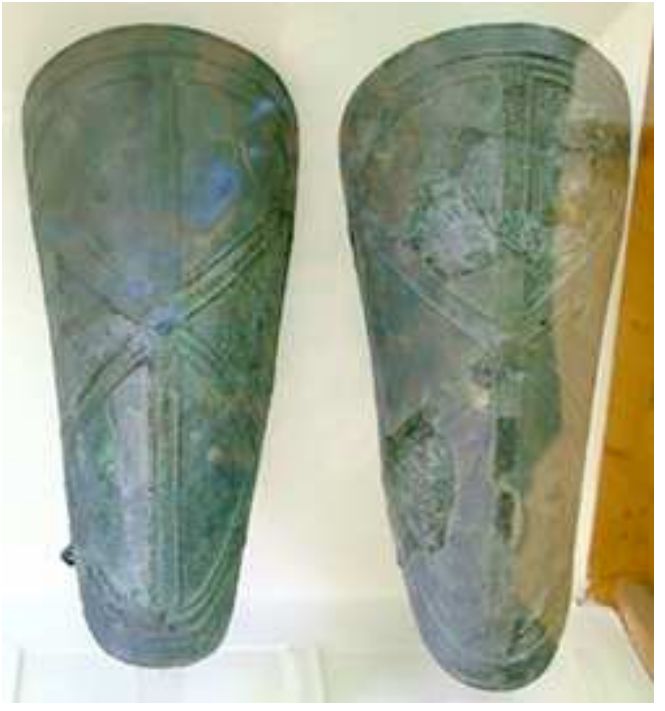

Fig. C8 Par de cnêmides proveniente do Túmulo do Guerreiro, em Kallithea, datadas do Heládico Recente IIIC.

Dimensões: $25,5 \mathrm{~cm}$ de altura and 12,6 $\mathrm{cm}$ de largura. Fonte da figura: $<$ http://www.salimbeti.com/micenei/ armour4.htm>. Último acesso em 11/04/2008.
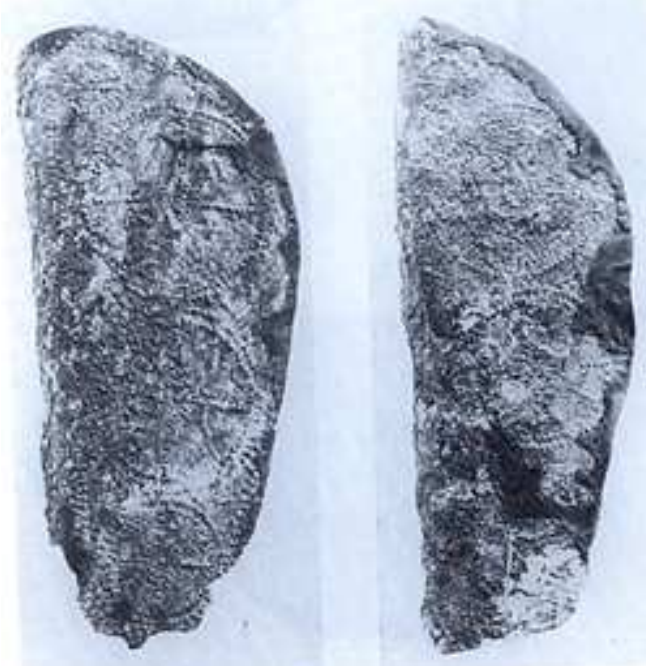

Fig. C9 Par de cnêmides proveniente de Câmara Tumular na face sul da Acrópole de Atenas datado do Heládico Recente IIIC. Fonte da figura: $<$ http://www.salimbeti.com/micenei/ armour4.htm >. Último acesso em 11/04/2008.

\section{Representações}

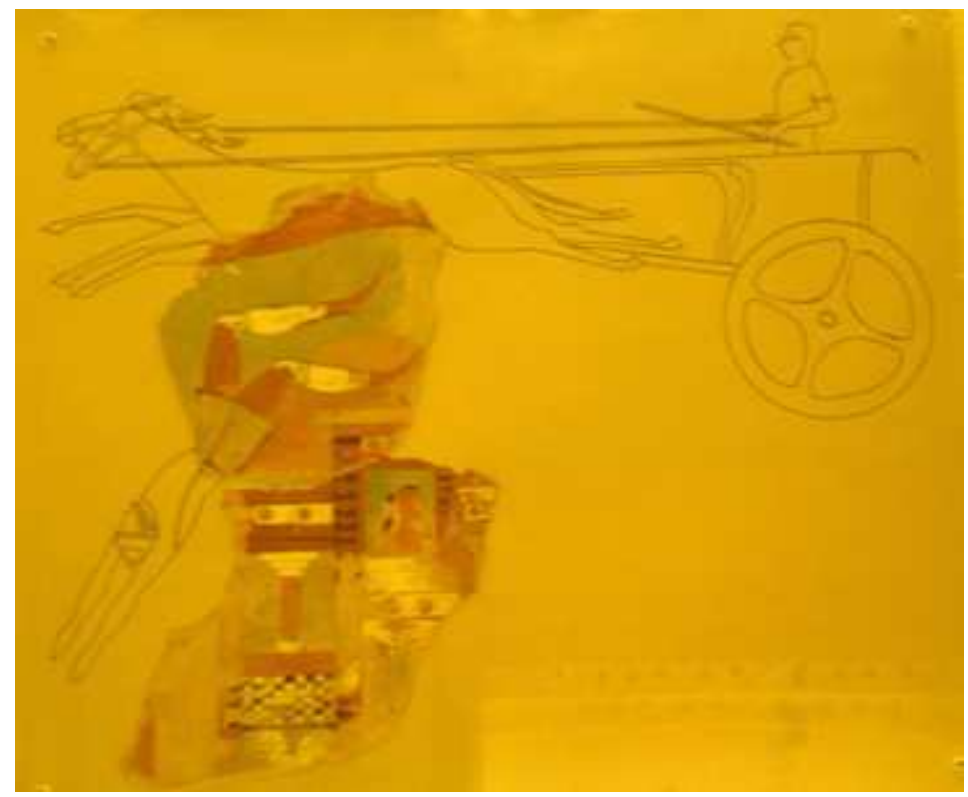

Fig. C10 Fragmento de afresco do Mégaron de Micenas, datado entre HRIIIA e HRIIIB (1370-1350 a.C.). A figura humana representada numa queda usa um par de cnêmides que alcança os joelhos ou está usando, além das cnêmides, algum tipo de joelheira. Fonte da figura:

<http://www.salimbeti.com/micenei/armour4.htm>. Último acesso em 11/04/208. 


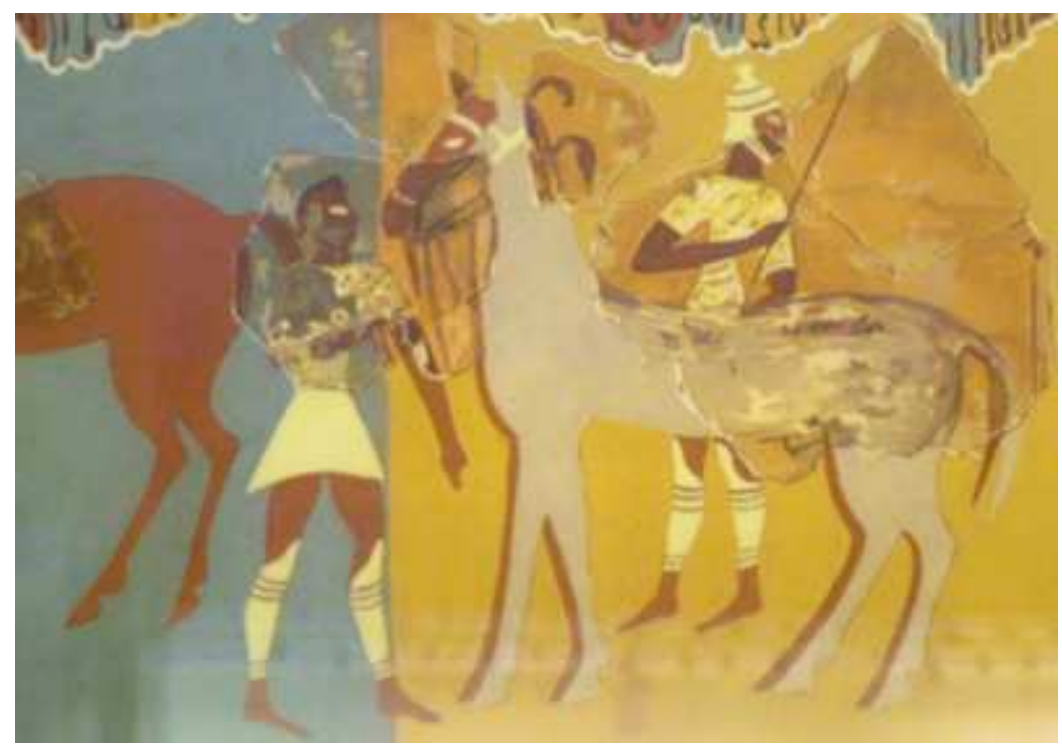

Fig. C11 Fragmentos de afresco do Mégaron de Micenas, datado entre HRIIIA e HRIIIB (1370-1350 a.C.). Fonte da figura: <http://www.salimbeti.com/micenei/armour4.htm>. Último acesso em $11 / 04 / 2008$.

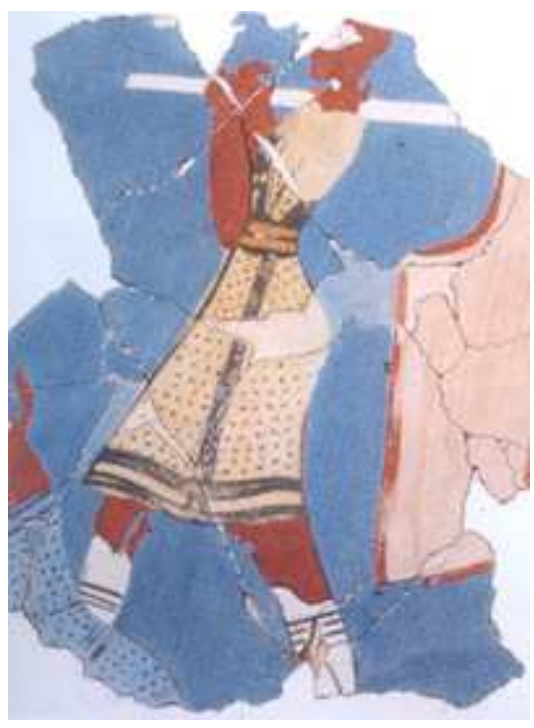

Fig. C12 Fragmento de afresco da casa do Mercador de Óleo, Micenas, datado entre HRIIIA e HRIIIB (13701350 a.C.). Fonte da figura: $<$ http://www.salimbeti.com/m icenei/armour4.htm>. Último acesso em 11/04/2008.

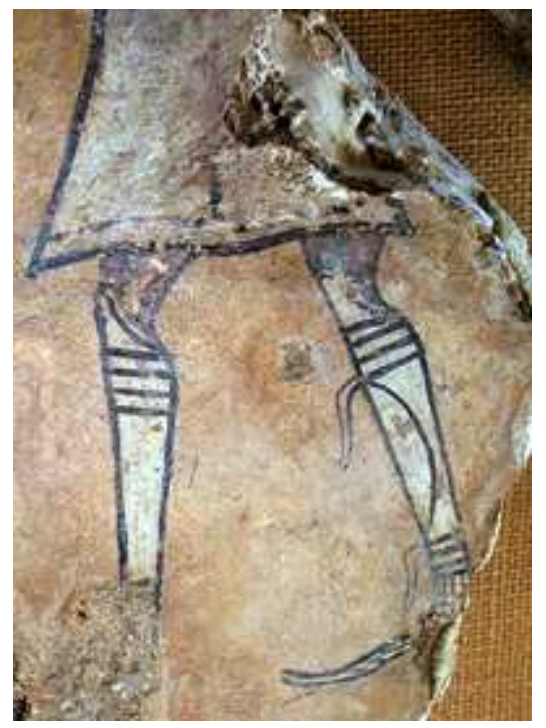

Fig. C13 Fragmento de afresco de Pilos datado de 1300 a.C. Fonte da figura: $<$ http://www.salimbeti.com/m icenei/armour4.htm>. Último acesso em 11/04/2008. 


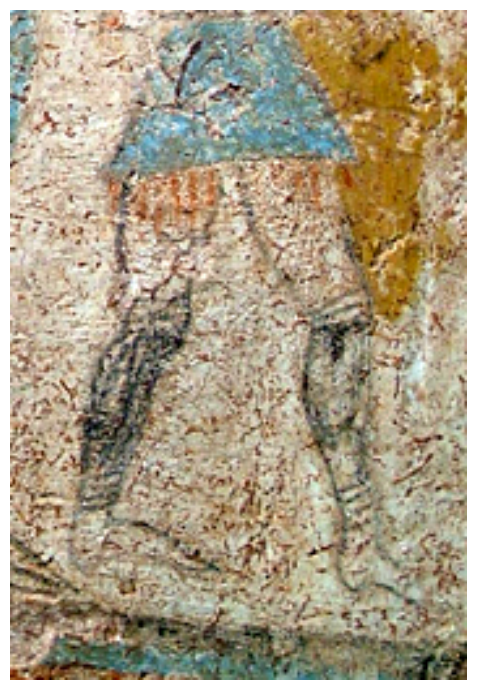

Fig. C14 Detalhe da Estela dos Guerreiros, proveniente de Micenas datado do Heládico Recente III. Fonte da figura:

<http://www.salimbeti.com/ micenei/armour4.htm>.

Último acesso em 11/04/2008.

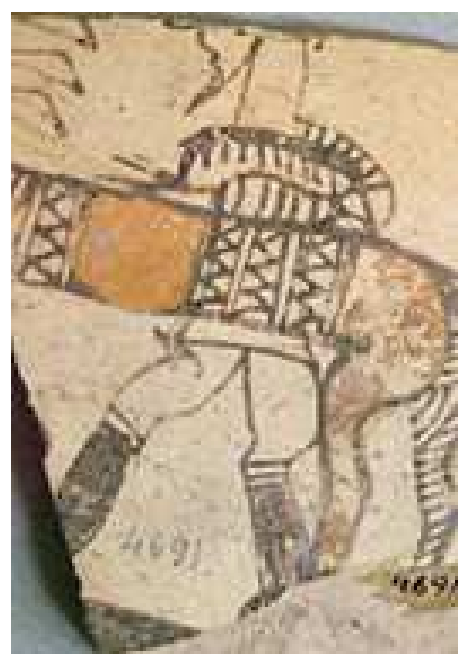

Fig. C16 Fragmento do "Vaso do Noivo", proveniente de Micenas, datado do Heládico Recente III. Fonte da figura:

$<$ http://www.salimbeti.com/ micenei/armour4.htm>.

Último acesso em 11/04/2008.

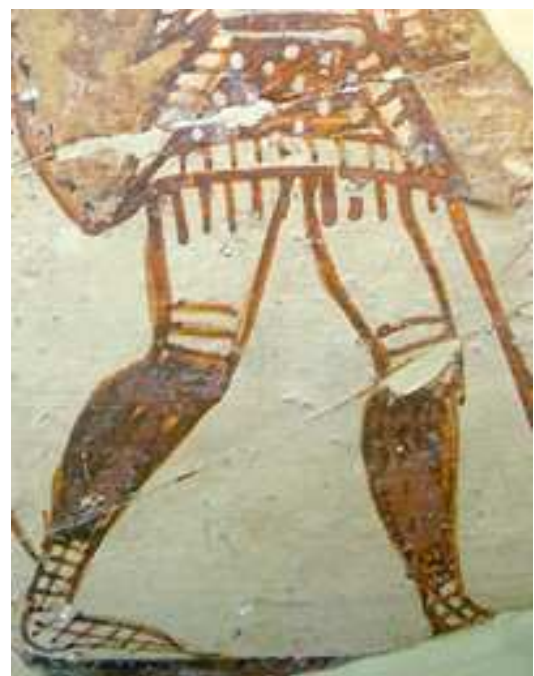

Fig. C15 Detalhe do Vaso dos Guerreiros, proveniente de Micenas datado do século XII a.C. Fonte da figura:

<http://www.salimbeti.com/ micenei/armour4.htm>.

Último acesso em 11/04/2008.

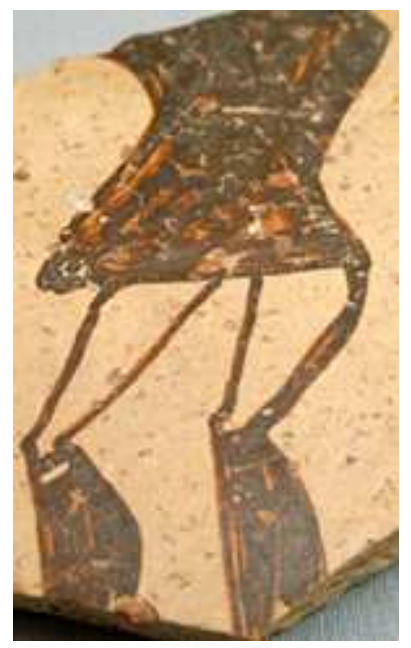

Fig. C17 Fragmento cerâmico proveniente de Micenas, datado do Heládico Recente III. Fonte da figura: $<$ http://www.salimbeti.com/ micenei/armour4.htm>. Último acesso em 11/04/2008. 


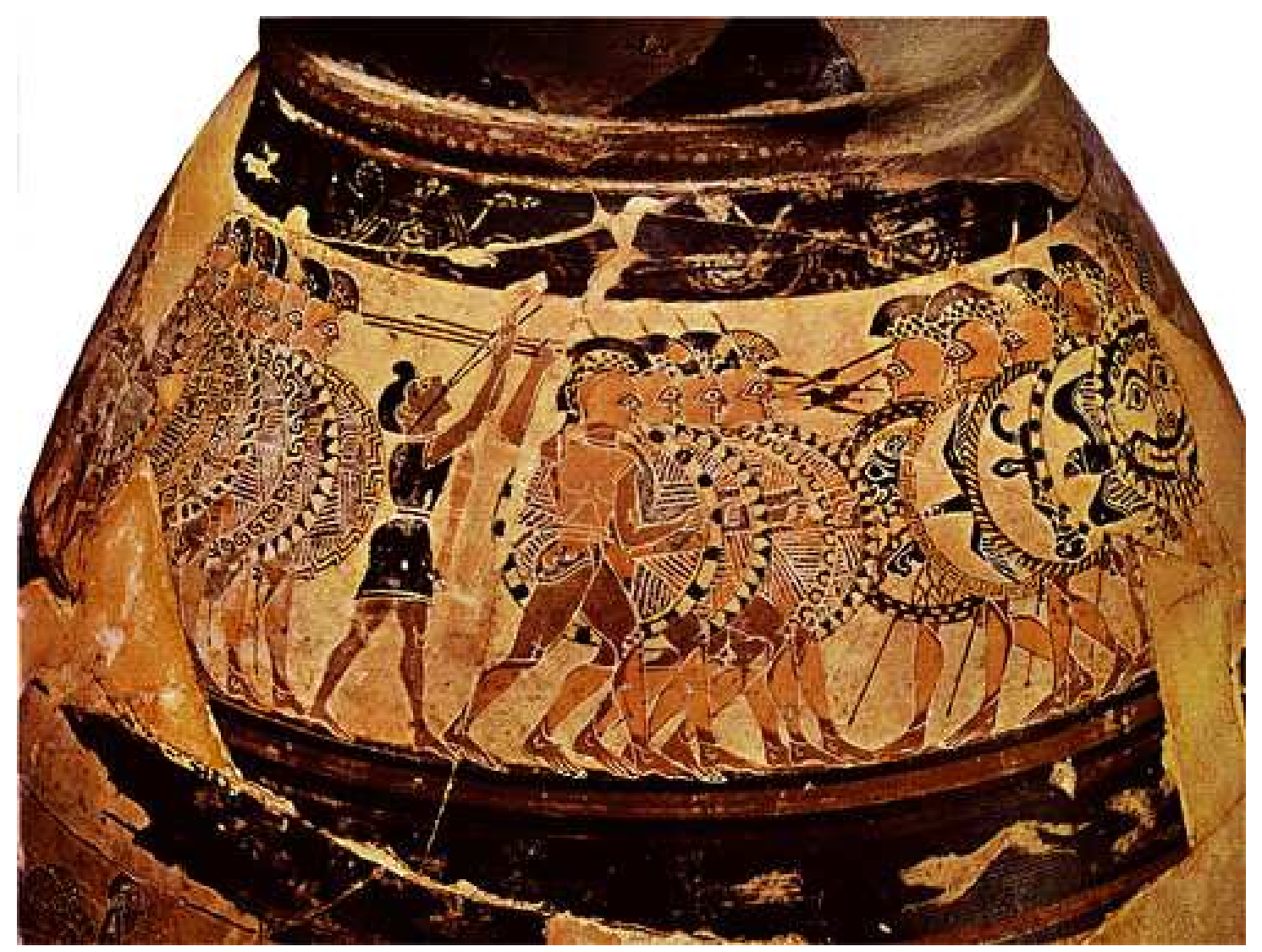

Fig. C18 Vaso Chigi, enócoa em estilo Proto-coríntio proveniente da Etrúria datada de c.620 a.C. Fonte da figura: <http://www.utexas.edu/courses/introtogreece/lect10/img10chigivase.html>. Último acesso em 11/04/2008. 
Prancha Armadura e Corselete

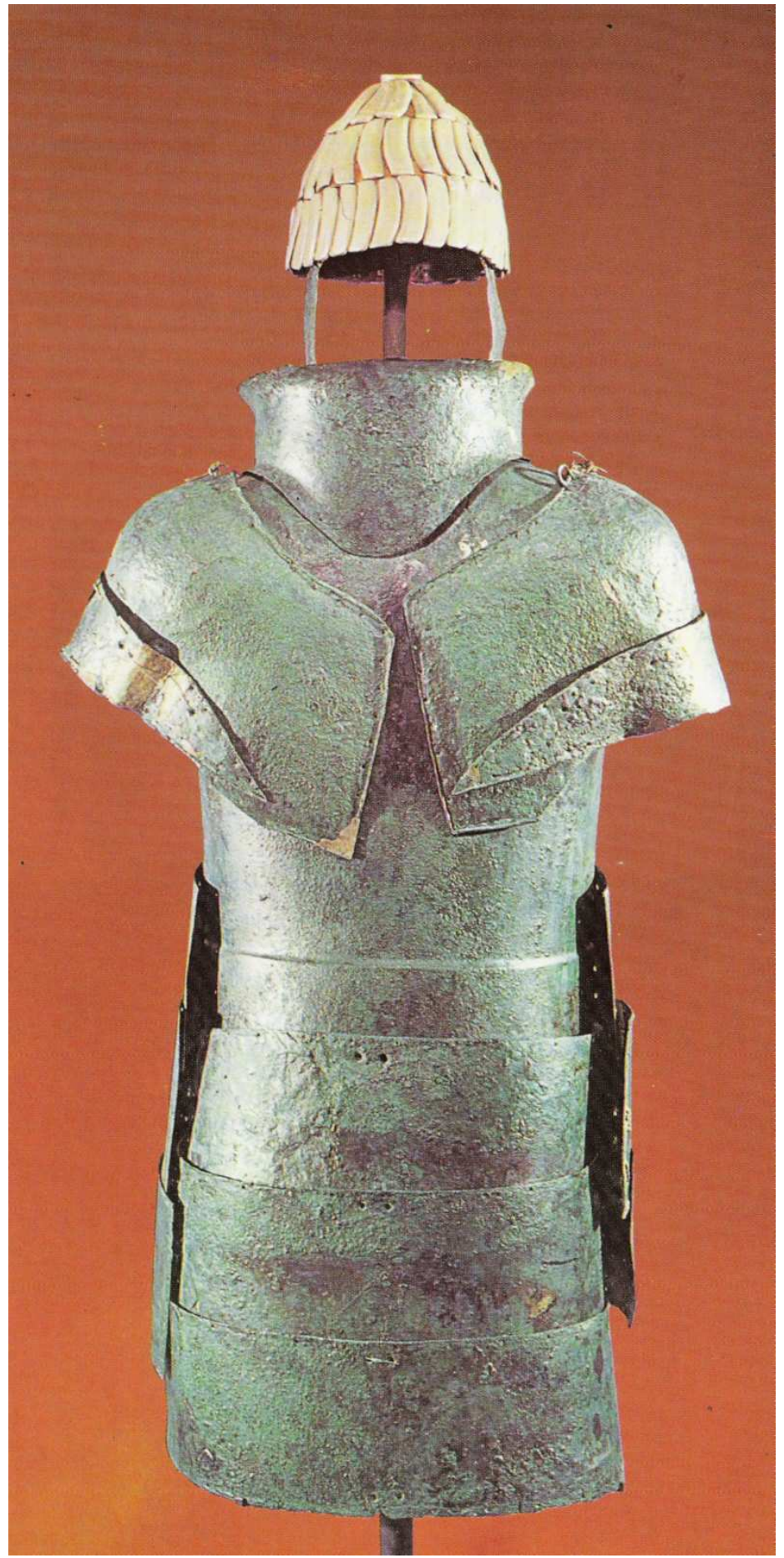

Fig. AC1. Armadura em bronze com elmo em dentes de javali. Proveniente de Dendra, Argólida. Cerca de 1425 a.C. Fonte da figura: Papajatsis, 1986, p. 23. 


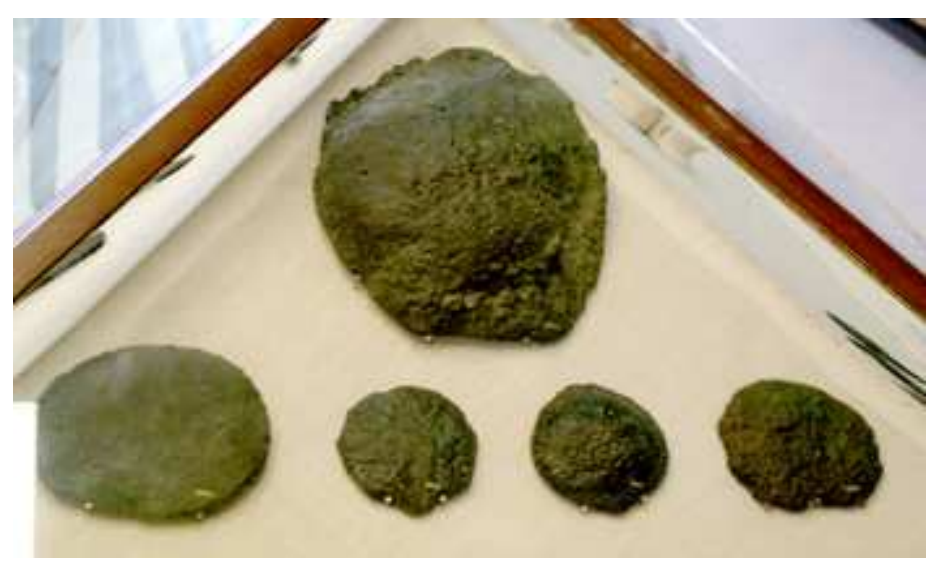

Fig. AC2. Cinco chapas de bronze datadas de cerca de 1500 a.C. provenientes de Archalachori, em Creta. As dimensões são, respectivamente, $15 \mathrm{~cm}$ de diâmetro para a maior delas, $10 \mathrm{~cm}$ para a média e $5-6 \mathrm{~cm}$ para as três menores. Pequenas perfurações, que não podem ser observadas através dessa imagem, existem no em torno das chapas e poderiam ser usadas para a sua fixação ao corselete em material perecível. Fonte da figura: <http://www.salimbeti.com/micenei/armour2.htm>. Último acesso em 23/10/2008.
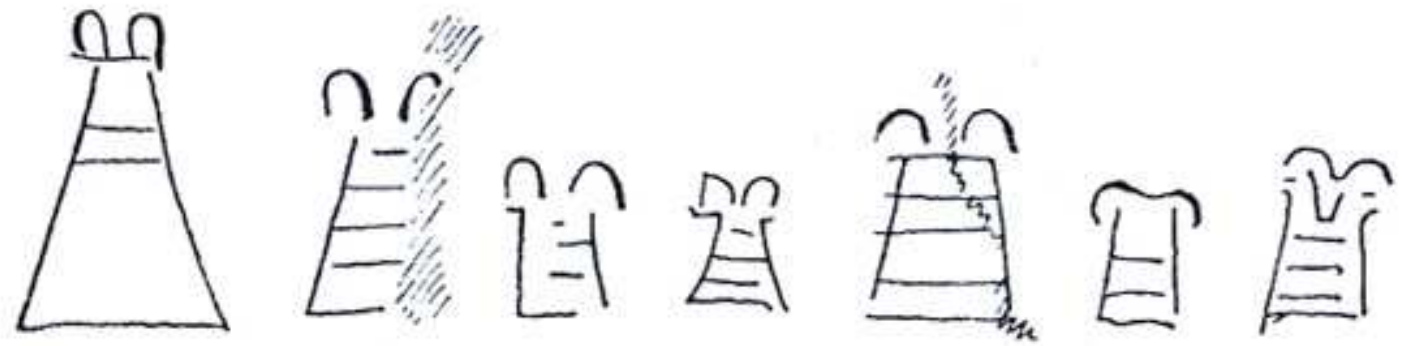

Fig. AC3. Ideogramas em Linear B de tabletes de Knossos que correspondem a armaduras ou corseletes. Fonte da figura: <http://www.mlahanas.de/Greeks/war/Armor/arm1.jpg >. Último acesso em 20/10/2008. 


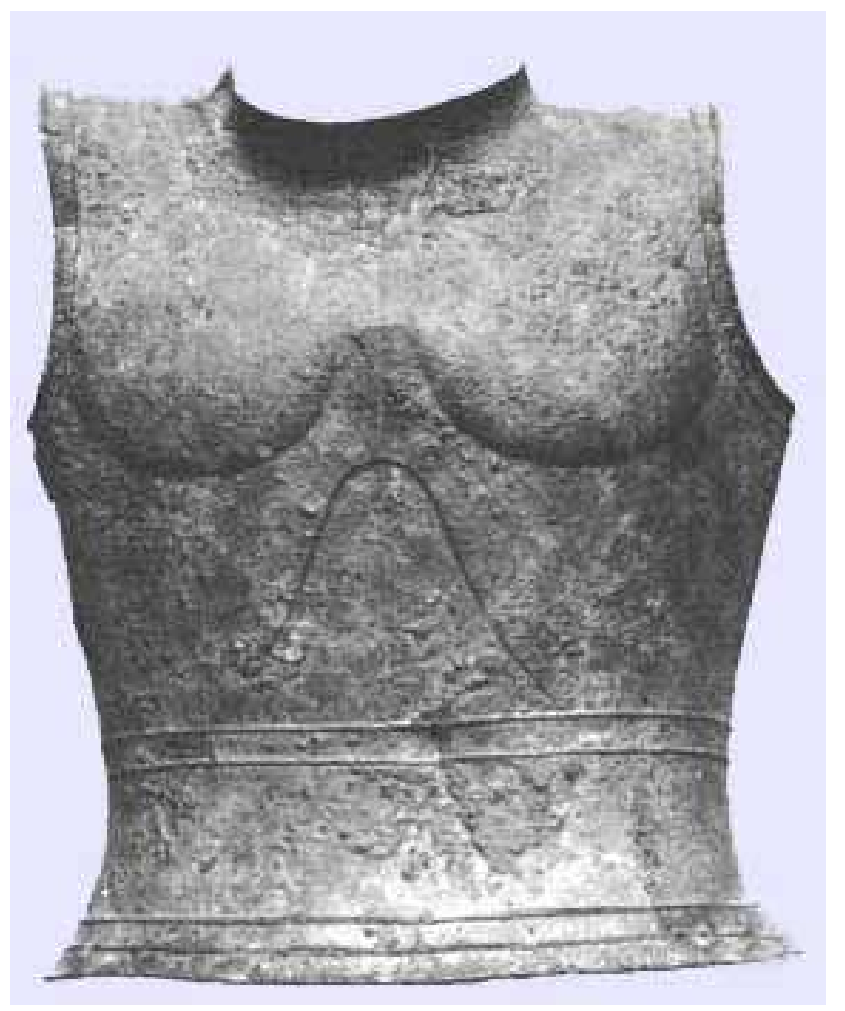

Fig. AC4. Corselete em bronze. Proveniente de Argos. Cerca de 725 a.C. Dimensão: $49 \mathrm{~cm}$ de altura. Fonte da figura: <http://www.mlahanas.de/Greeks/war/Armor/arm1.jpg >. Último acesso em 20/10/2008. 


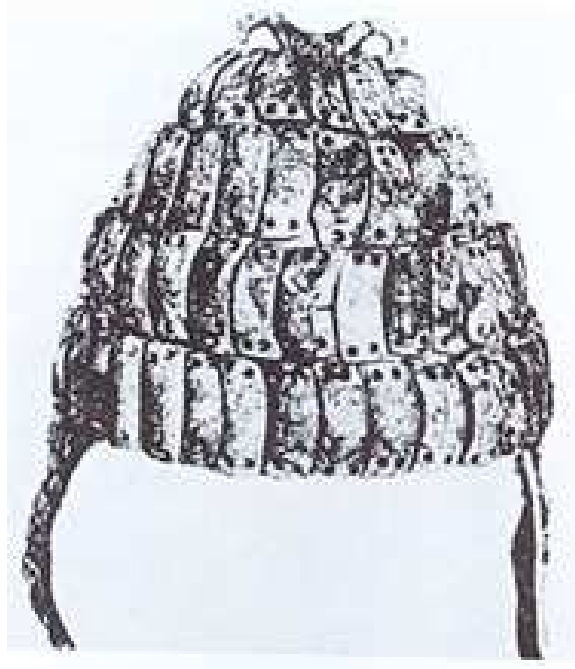

Fig.E1 Elmo em dentes de javali (reconstruído). Micenas. Século XVI a.C. Fonte da figura:

$<$ http://www.salimbeti.com/micenei/hel mets2.htm>. Último acesso em $02 / 10 / 2008$.

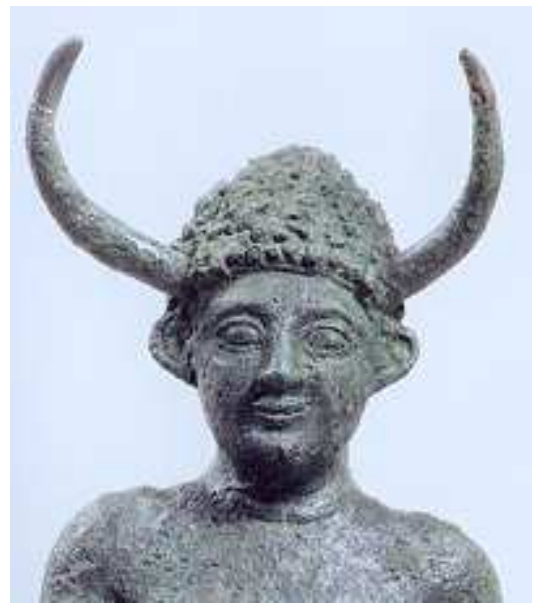

Fig. E3 Detalhe de estatueta em bronze proveniente de Enkomi, Chipre. Heládico Recente IIIC. Fonte da figura: $<$ http://www.salimbeti.com/micenei/hel mets3.htm>. Último acesso em 20/10/2008.

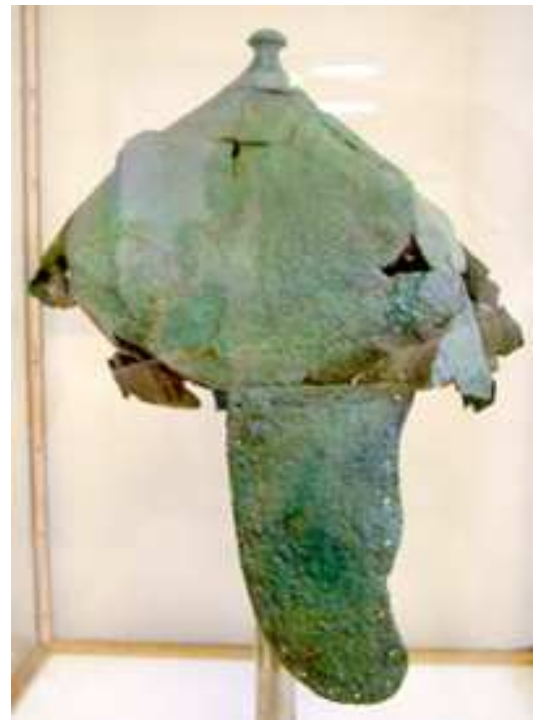

Fig.E2 Elmo em bronze. Cnossos, Creta. Século XV a.C. Fonte da figura: $<$ http://www.salimbeti.com/micenei/hel mets2.htm>. Último acesso em $02 / 10 / 2008$.

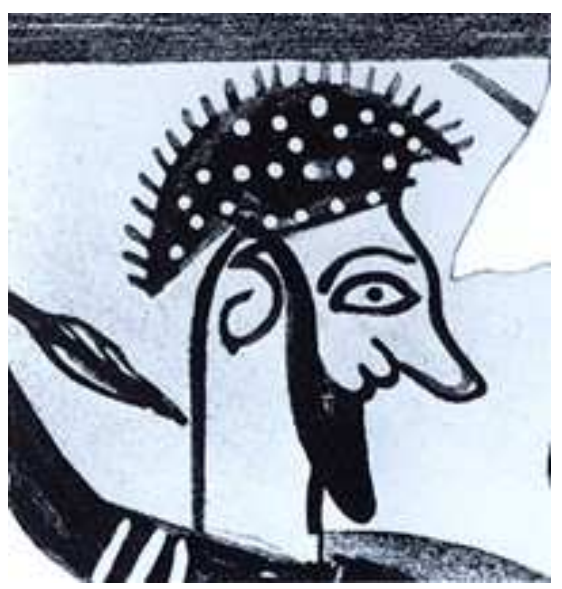

Fig. E4 Detalhe da Face B do Vaso dos Guerreiros. Fonte da figura: $<$ http://www.salimbeti.com/micenei/hel mets3.htm>. Último acesso em 20/10/2008. 


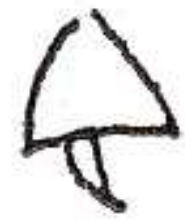

Fig. E5 Ideograma em Linear B correspondente ao elmo. Fonte da figura:

$<$ http://www.salimbeti.com/micenei/helmets3.htm>. Último acesso em 20/10/2008.

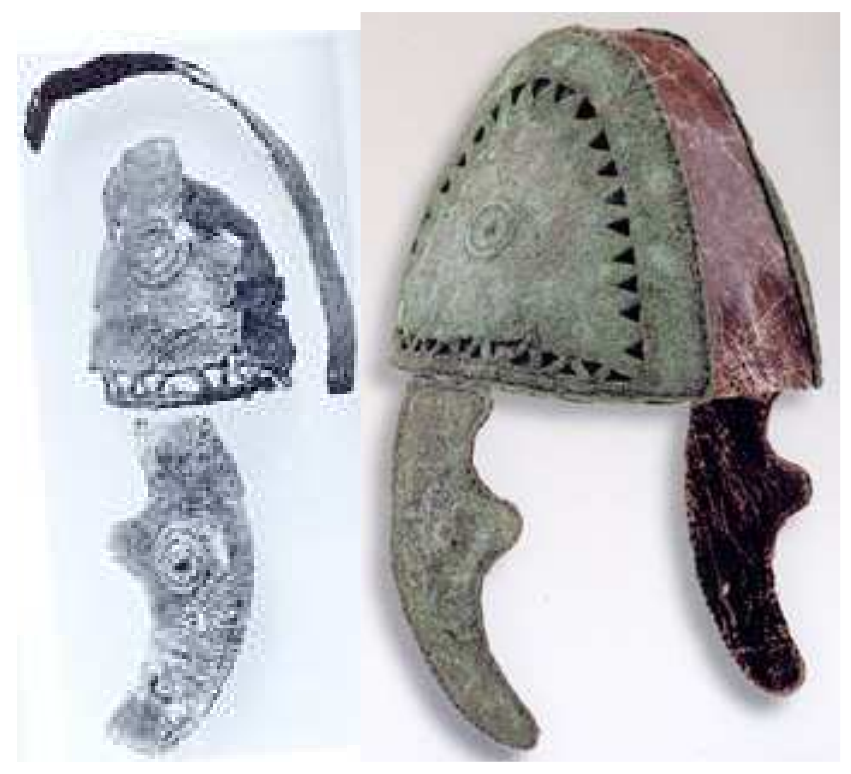

Fig. E6 Elmo em bronze proveniente de Tirinto e sua reconstituição. Túmulo XXVIII. Cerca de 1050 a.C. Fonte da figura:<http://www.salimbeti.com/micenei /helmets3.htm>. Último acesso em 20/10/2008.
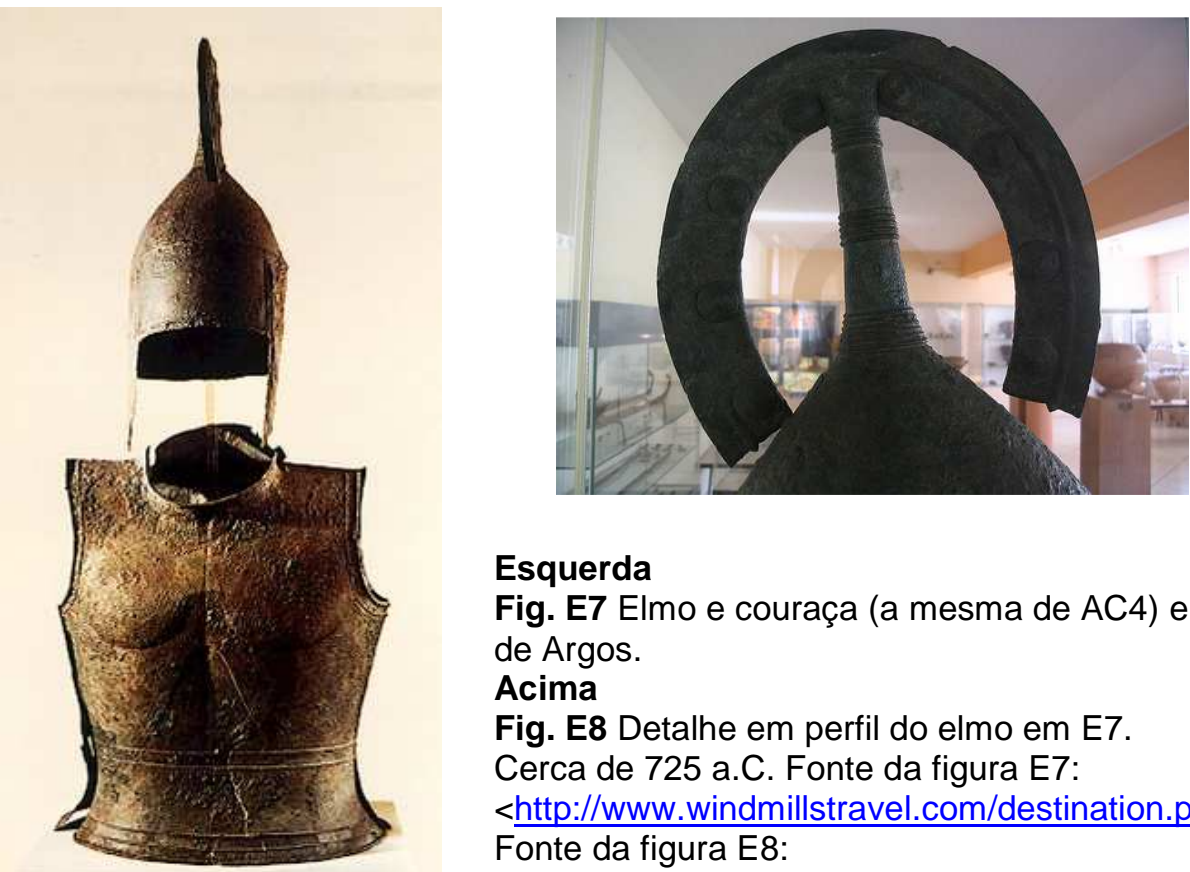

\section{Esquerda}

Fig. E7 Elmo e couraça (a mesma de AC4) em bronze proveniente de Argos.

Acima

Fig. E8 Detalhe em perfil do elmo em E7.

Cerca de 725 a.C. Fonte da figura E7:

$<$ http://www. windmillstravel.com/destination.php?type $=$ city\&id $=15>$ Fonte da figura E8:

$<$ http://flickr.com/photos/dandiffendale/2760928270/in/set72157606707390236/>. Último acesso em 18/12/2008. 
Prancha Escudo

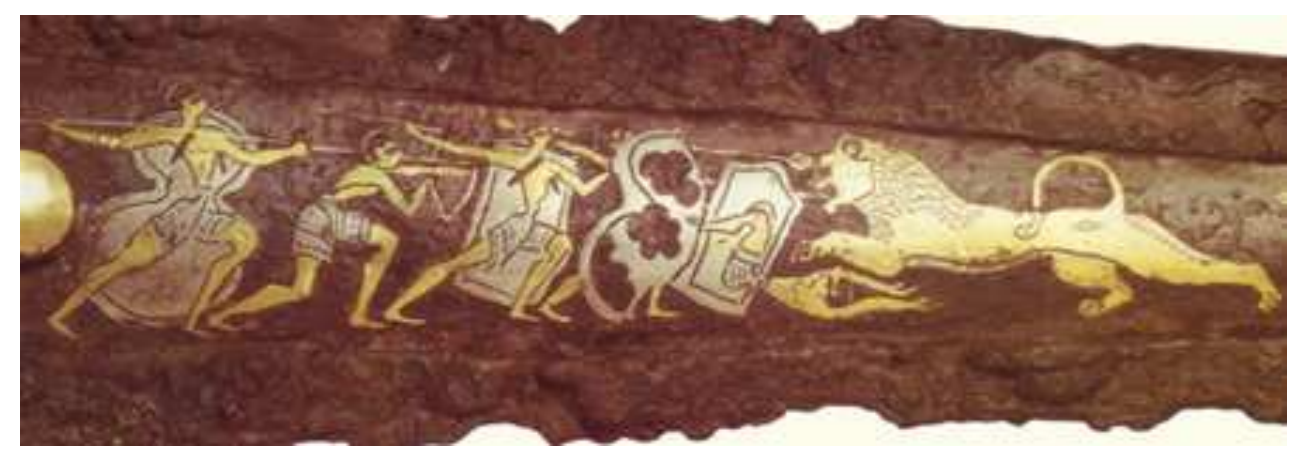

Fig. ES1 Adaga da Caça ao Leão, com representações do escudo 'em torre' e do escudo 'em oito' e do télamon. Proveniente do Túmulo em Poço IV, Micenas. 1550-1500 a.C. Museu Arqueológico Nacional de Atenas. Fonte da figura: <http://www.salimbeti.com/micenei/shields1.htm $>$. Último acesso em 15/10/2008.

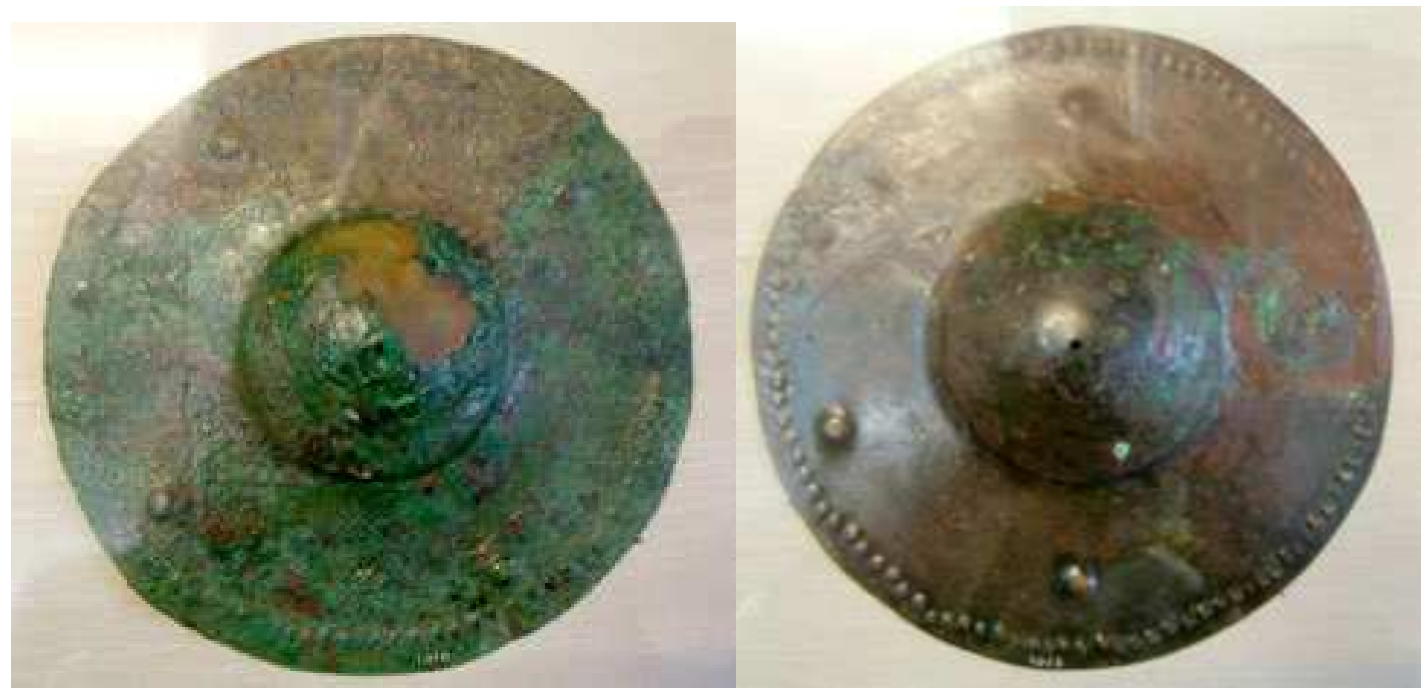

Fig. ES2 Dois discos (ônfalos) em bronze. Dimensões: $19 \mathrm{~cm}$ cada. Provenientes do Túmulo B7 de Mouliana, Creta. 1300-1200 a.C. Fonte da figura: <http://www.salimbeti.com/micenei/shields2.htm>. Último acesso em 15/10/2008.

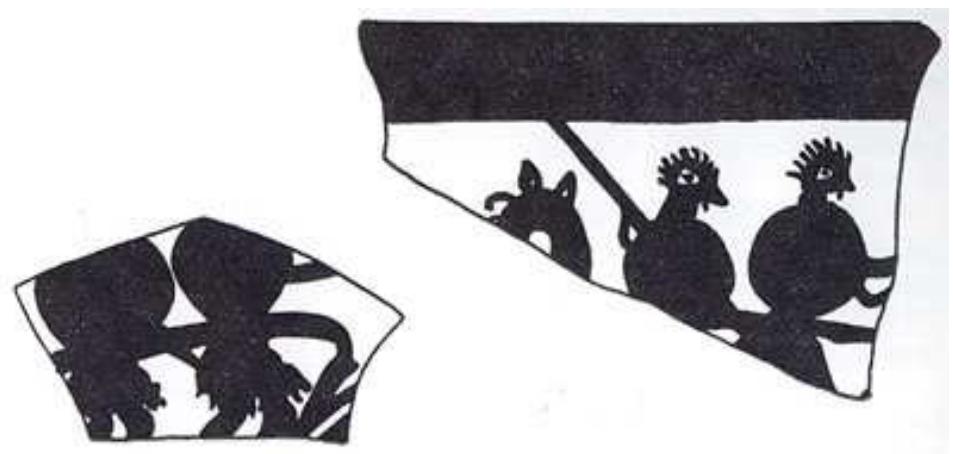

Fig. ES3 Fragmento cerâmico de uma cratera. Proveniente de Micenas. Estilo IIIC. Cerca de 1200 a.C. Fonte da figura: <http://www.salimbeti.com/micenei/shields2.htm>. Último acesso em 19/10/2008. 


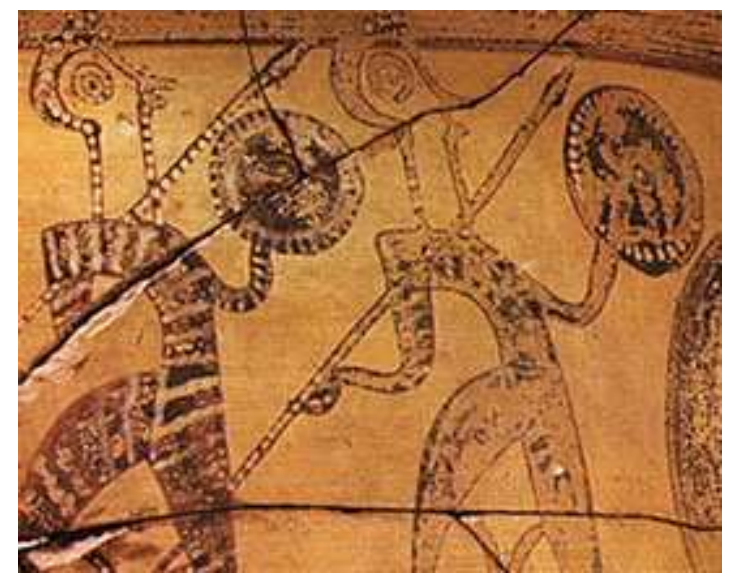

Fig. ES4 Fragmento cerâmico Proveniente de Tirinto. Cerca de 1250 a.C. Fonte da figura:

http://www.salimbeti.com/micenei/shields2.htm Último acesso em 19/10/2008.

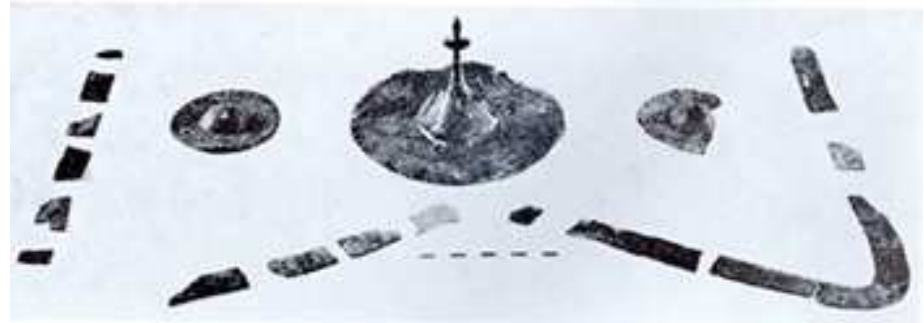

Fig.ES5 Fragmentos em bronze acompanhados de três ônfalos $(16,2 \mathrm{~cm} ; 8,4 \mathrm{~cm}$ e 8,4 cm). Provenientes do túmulo 40, Kaloriziki (Kurion), Chipre. Fonte da figura:

$<$ http://www.salimbeti.com/micenei/shields3.htm>. Último acesso em 02/10/2008.

Fig. ES6 Fragmento de uma cratera ática mostrando uma figura portando um escudo em forma de ampulheta entre dois arqueiros. Proveniente do cemitério do Dípilon, Atenas. Metade do século VIII a.C. Louvre, Paris, A530 [s488]. Fonte da figura:

$<$ http://upload.wikimedia.org/wikipedia/ commons/f/f7/Warriors Dipylon Maste r Louvre S523.jpg>. Último acesso em 20/10/2008.

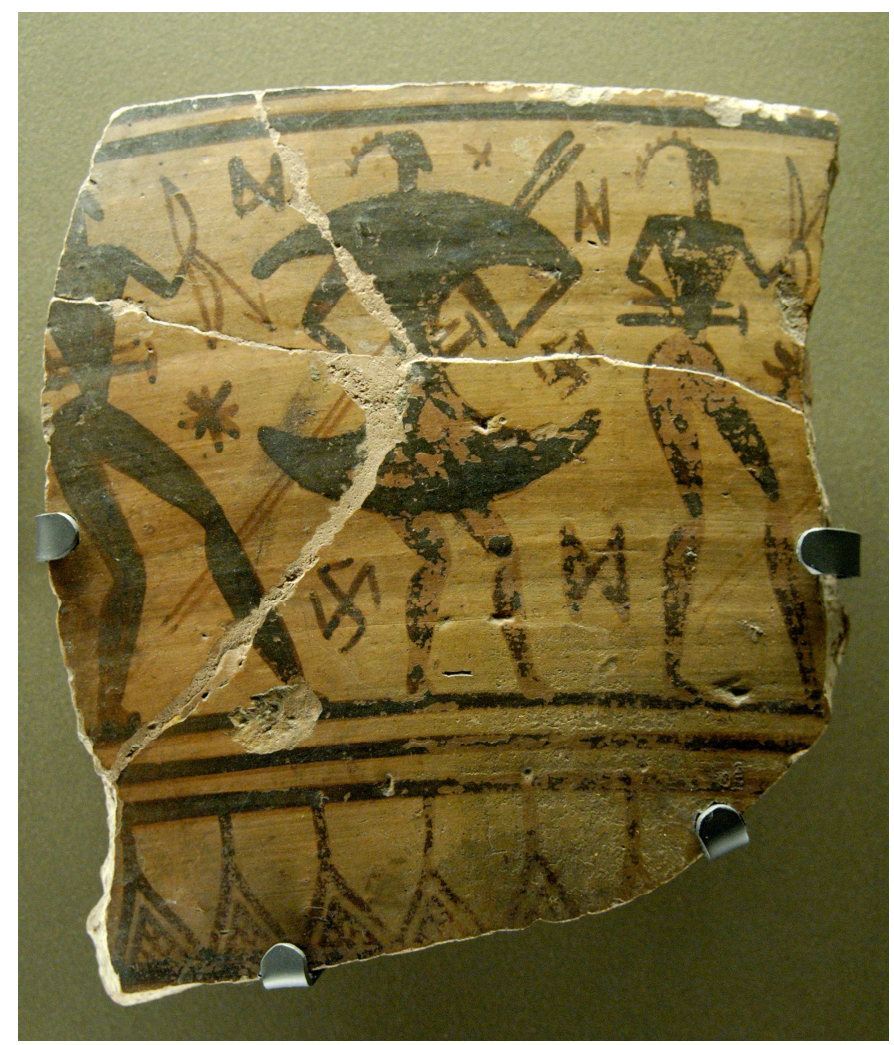


Prancha Espadas

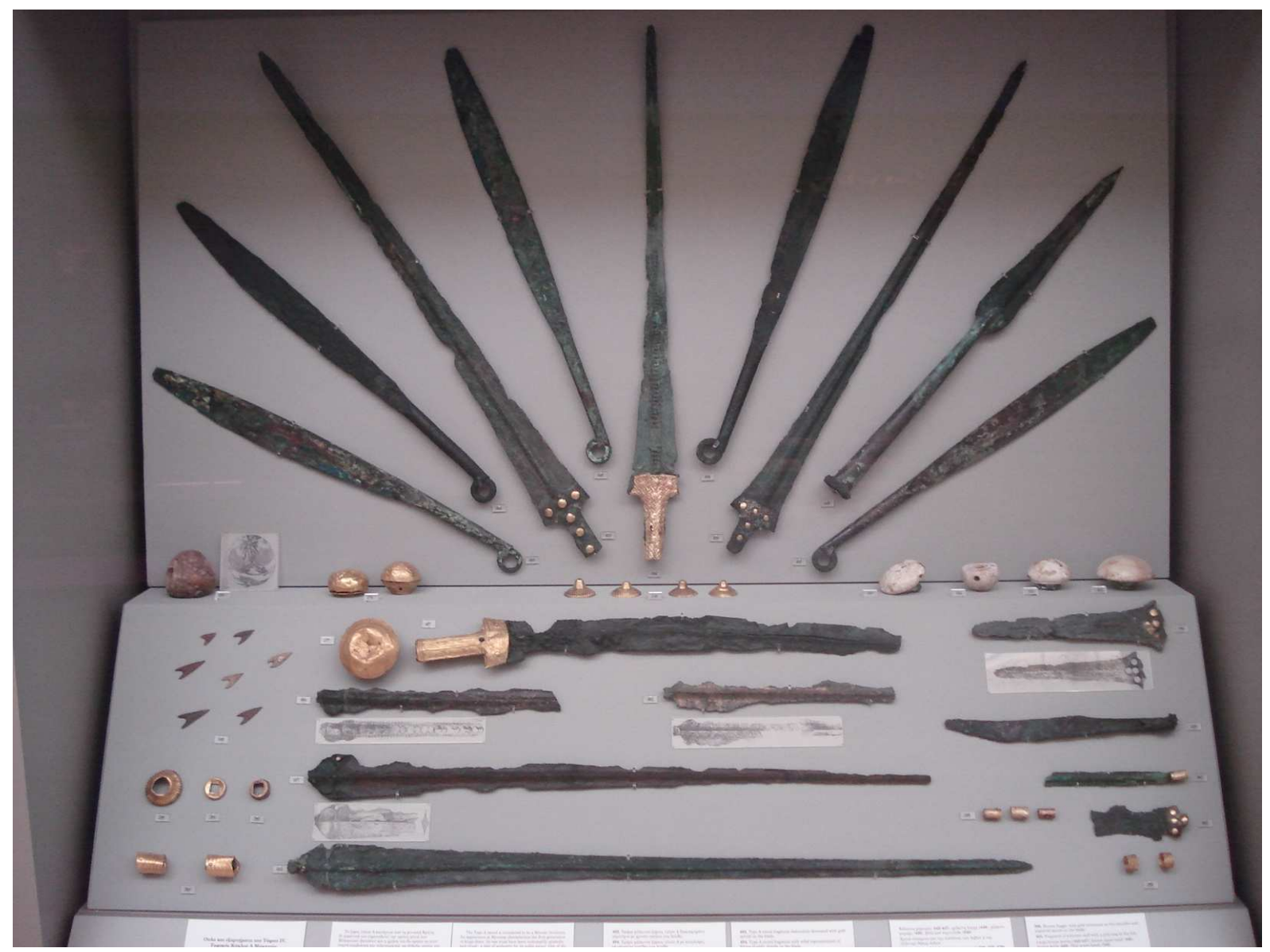

Fig. ESP1 Algumas das espadas, dentre outros achados, encontradas no Círculo Tumular A em Micenas expostas numa vitrine do Museu Arqueológico Nacional de Atenas. Fonte da figura: concessão do acervo pessoal de Gilberto da Silva Francisco. 


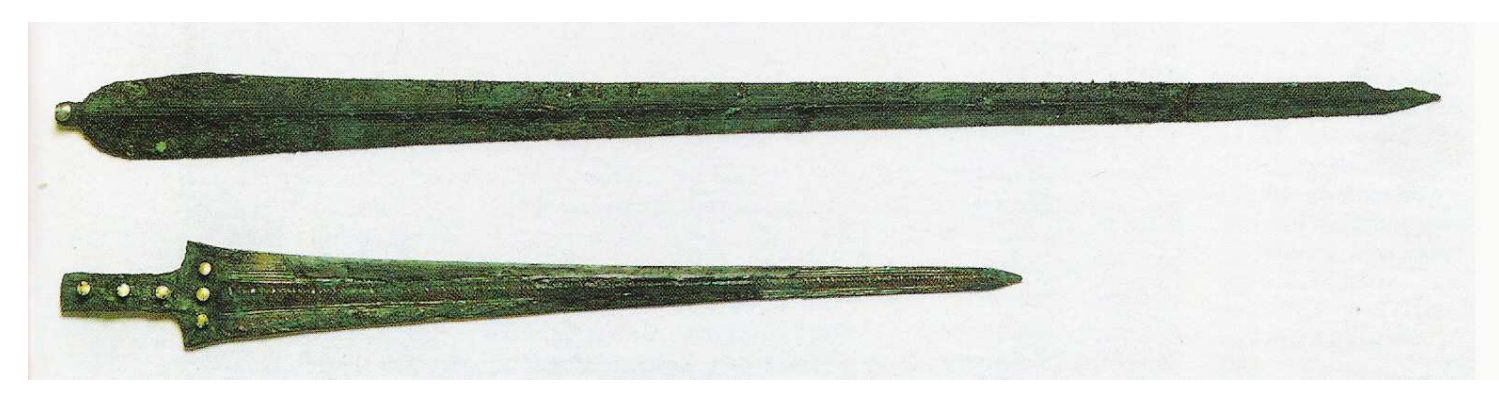

Fig. ESP2 Superior Espada do tipo A, de invenção minóica. Inferior Espada do tipo B de criação micênica. Ambas as lâminas são de bronze; o exemplar do tipo $A$ apresenta um cravo em prata e o exemplar do tipo B apresenta cravos em ouro. Segunda metade do século XVI a.C. Museu Arqueológico Nacional de Atenas. Foto Y. Fafalis. Fonte da imagem: Les Myceniens: Des Grecs du Ile millénaire, Editions Fatons, Dijons, 1994 (obra coletiva), p. 29.

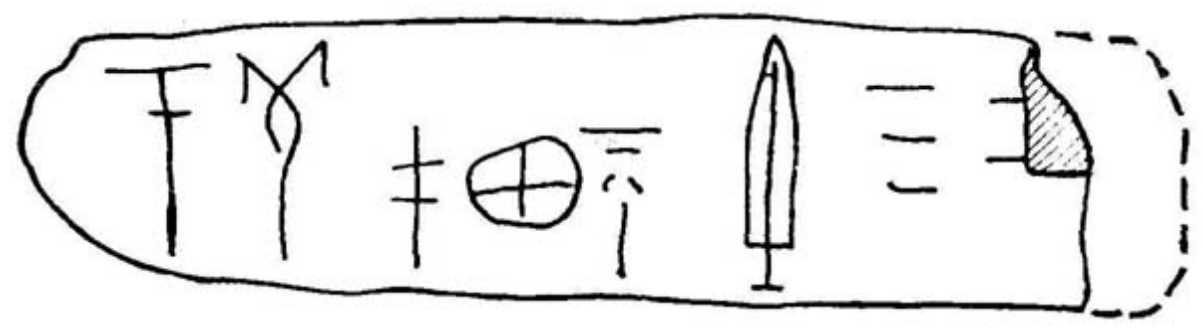

Fig. ESP3 Tablete em Linear B que apresenta o ideograma para a espada. Fonte: Chadwick, p.173. 
Prancha Lança e Dardo

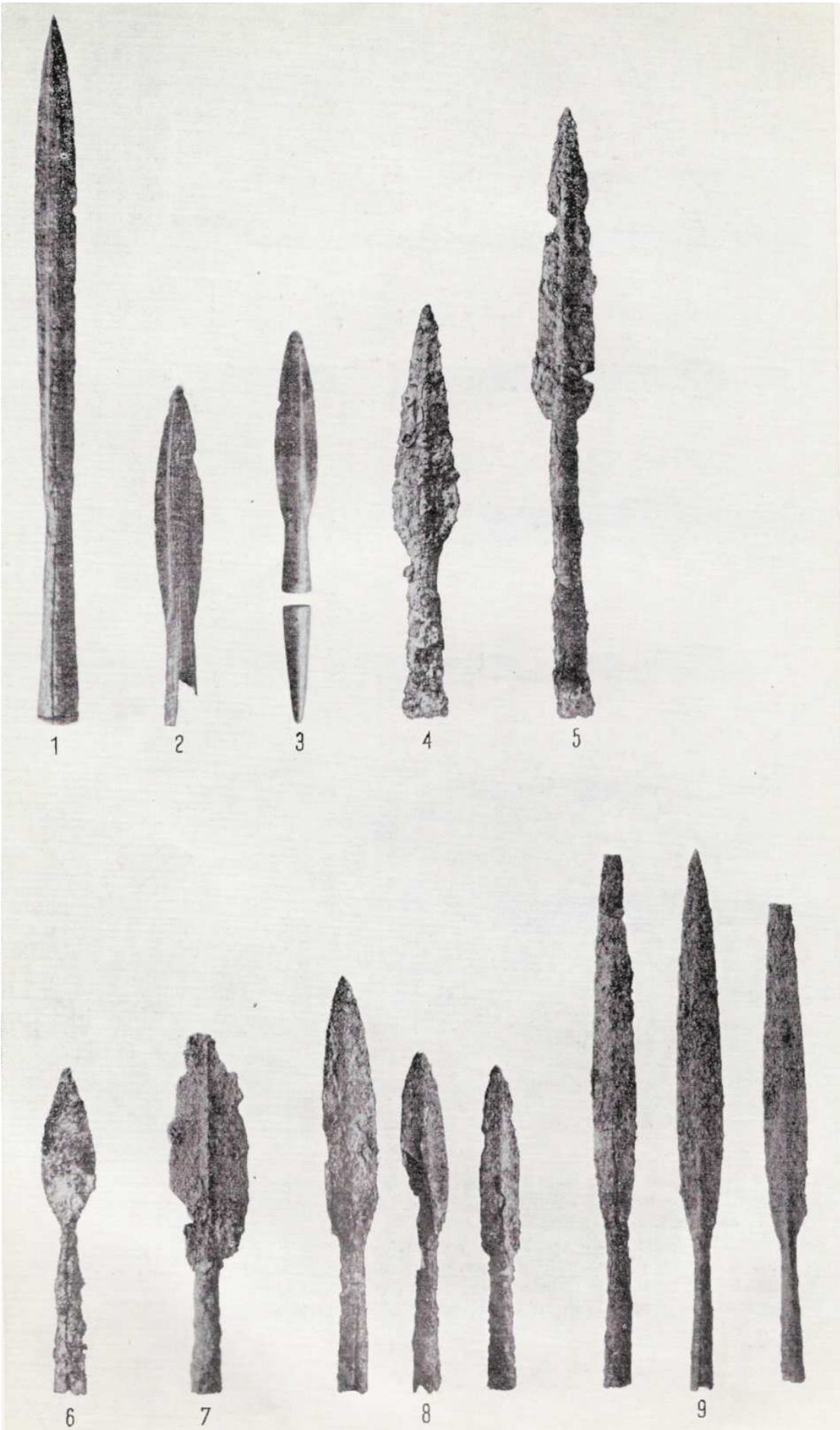

Fig. LD1 Pontas de lanças. 1. Proveniente de Cnossos, c.1450 a.C. $(0,50 \mathrm{~m})$. 2. Kallithéa, túmulo A, c. 1200 a.C. $(0,23 \mathrm{~m})$. 3. Kallithéa, túmulo $B$, c. 1150 a.C. $(0,19 \mathrm{~m}$; talão $0,09 \mathrm{~m})$. 4. Cerâmico, fim do século $X$ a.C. $(0,32 \mathrm{~m})$. 5. Cerâmico, $900-850$ a.C. $(0,50 \mathrm{~m})$. 6. Cerâmico, 800-775 a.C. $(0,25 \mathrm{~m})$. 7 . Argos, c. 775 a.C. $(0,26 \mathrm{~m})$. 8. Tirinto, fim do século VIII a.C. (comprimento máximo 0,31m). 9. Argos, cerca de 700 a.C. (comprimento máximo $0,40 \mathrm{~m}$ ).

Fonte: Courbin, em Vernant, 1968, pl.2. 


\section{Prancha Arco e Flecha}

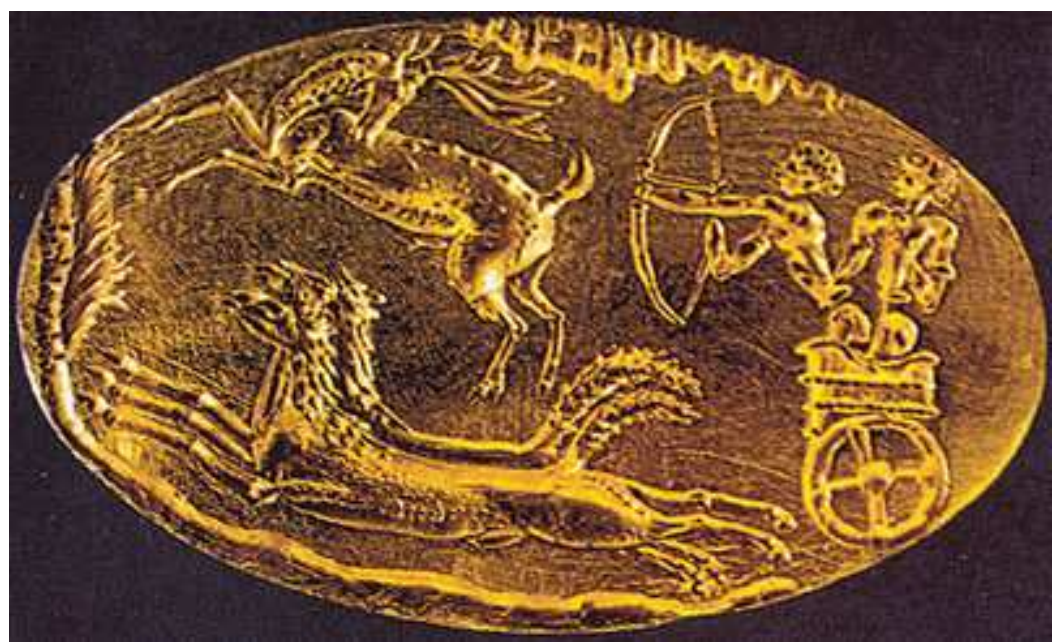

Fig. AF1 Anel-sinete em ouro com cena de caça em que o arqueiro é representado com um arco. Proveniente do Túmulo em Poço IV no interior do Círculo Tumular A. Micenas.

Cerca de 1550-1500 a.C.

Fonte da figura: <http://www.salimbeti.com/micenei/chariots.htm>. Último acesso em 03/12/2008.
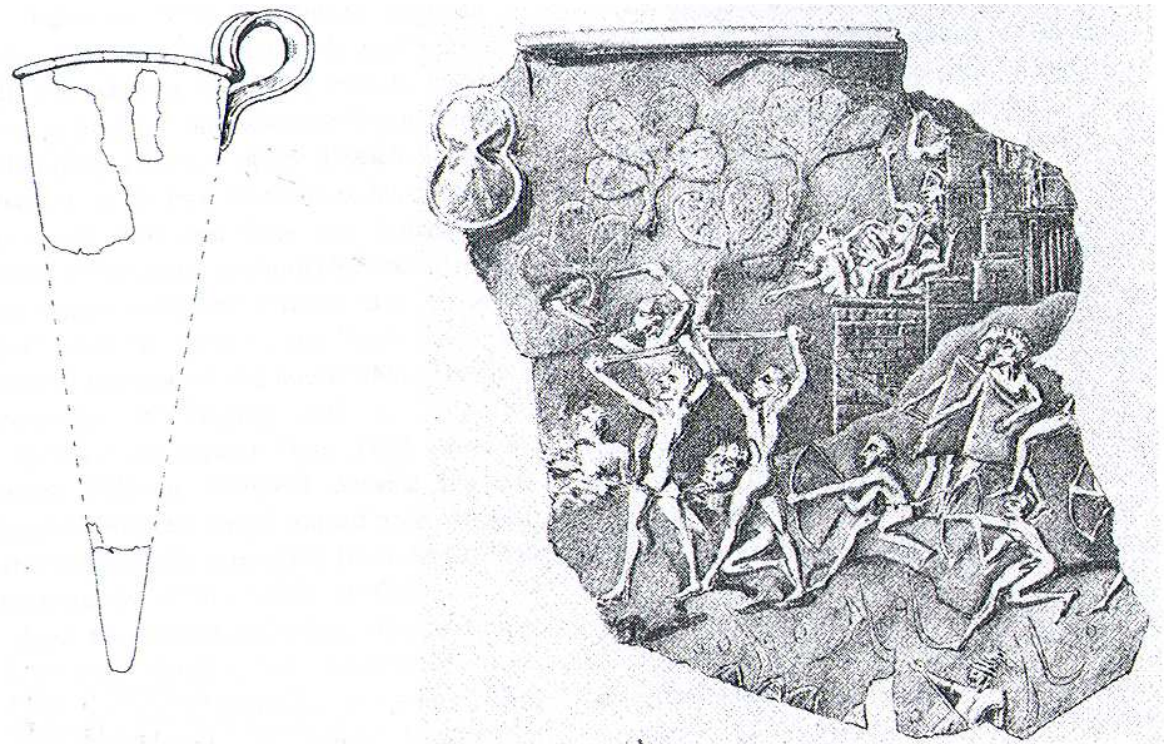

Fig. AF2 Fragmento de ríton em prata proveniente do Túmulo em Poço IV no interior Círculo Tumular A. Micenas. Cerca de 1550-1500 a.C. Fonte: Stubbings, 1973, p. 28, fig. 26a e 26b. 
Prancha Carro

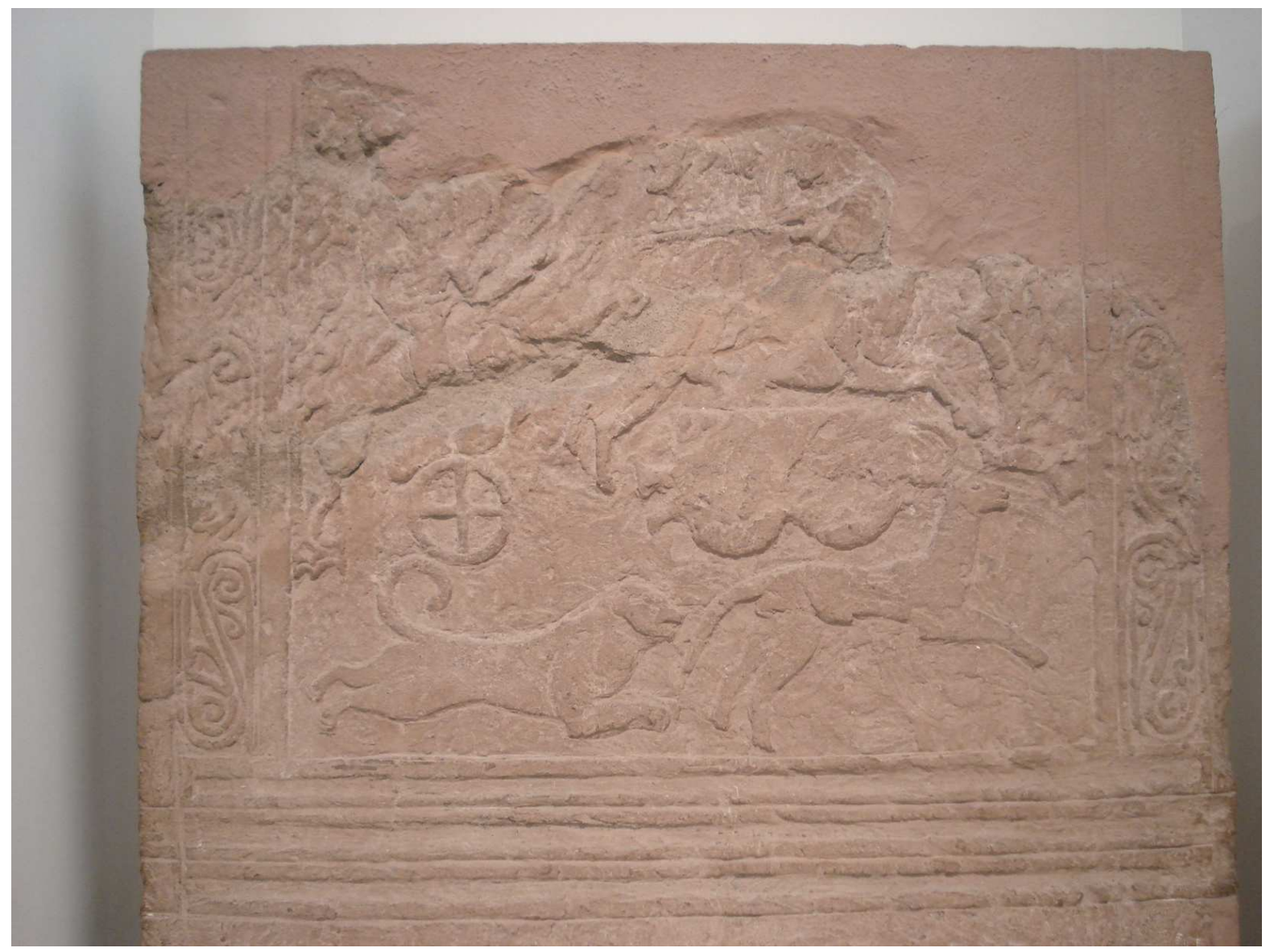

Fig. CA1 Estela funerária apresentando o relevo de um carro na cena do painel superior (note a roda de quatro raios). Encontrada por Schliemann no Túmulo em Poço V do Círculo Tumular A, Micenas. 1550-1500 a.C. Museu Arqueológico Nacional de Atenas, número de inventário 1427. Fonte da figura: acervo pessoal de Gilberto da Silva Francisco. 


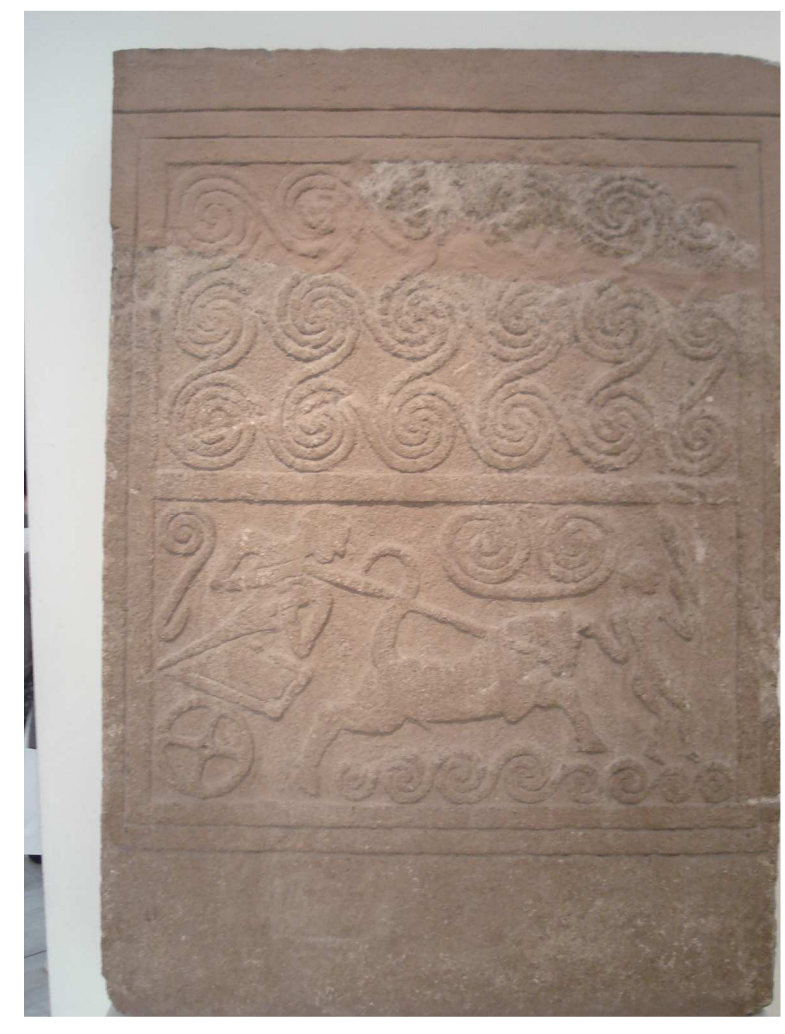

Fig. CA2 Estela funerária apresentando um painel em relevo com uma cena figurativa de um carro sendo guiado por uma figura humana portando uma espada. Encontrada por Schliemann no Túmulo em Poço $V$ do Círculo Tumular A, Micenas. 1550-1500 a.C. Museu Arqueológico Nacional de Atenas, número de inventário 1428. Fonte da figura: acervo pessoal de Gilberto da Silva Francisco.

Fig. CA3 Estela funerária apresentando um painel em relevo com uma cena figurativa de um carro. Encontrada por Schliemann no Túmulo em Poço V do Círculo Tumular A, Micenas. 1550-1500 a.C. Museu Arqueológico Nacional de Atenas, número de inventário 1429. Fonte da figura: acervo pessoal de Gilberto da Silva Francisco.

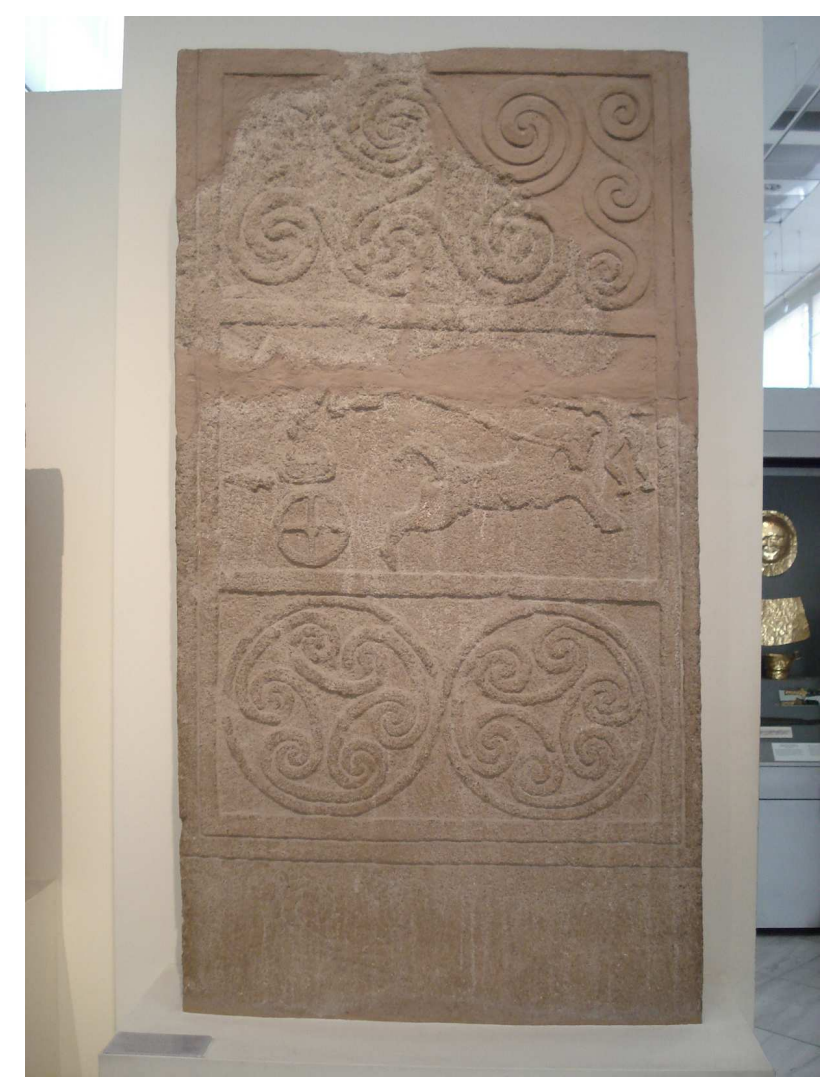




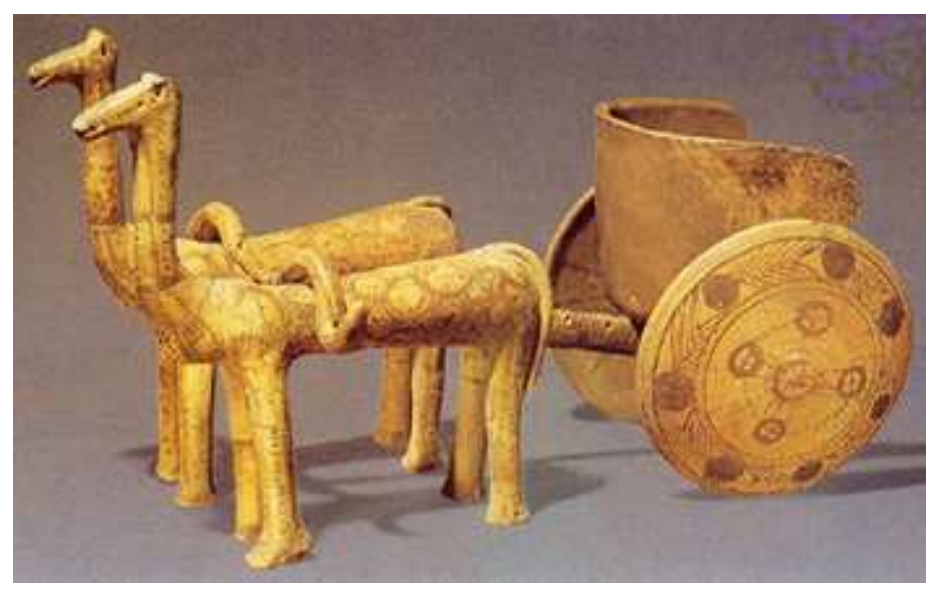

Fig. CA4 Miniatura de uma biga encontrada na Tessália, datada do século XIII a.C. Fonte da figura: $<$ http://www.salimbeti.com/micenei/chariots.htm>. Último acesso em 22/12/2008.

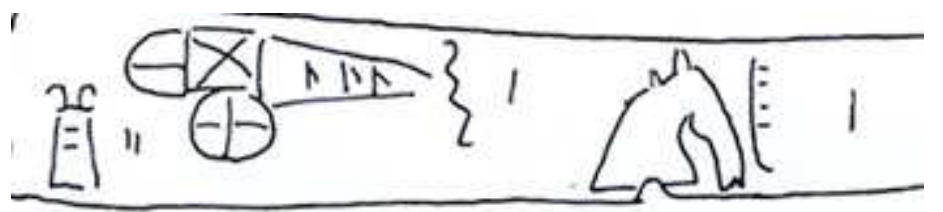

Knossos chariot tablet: Sc 217

Fig. CA5 Esquema de um tablete em Linear B proveniente de Cnossos com o ideograma para o carro. Fonte da figura: <http://www.salimbeti.com/micenei/chariots.htm>. Último acesso em 22/12/2008. 


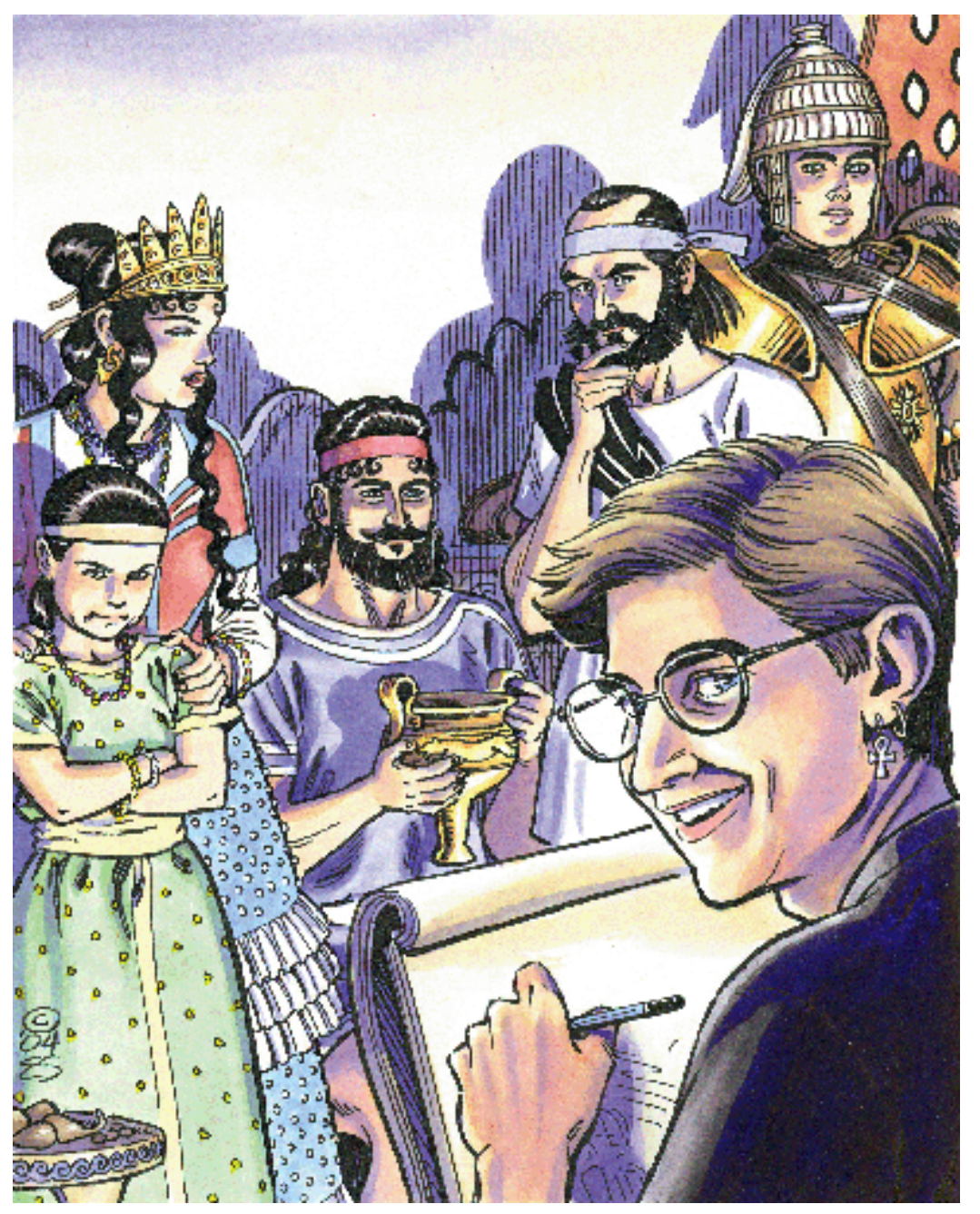

Capítulo 5

“Arqueologia Homérica”?

Os desencontros de uma disciplina 


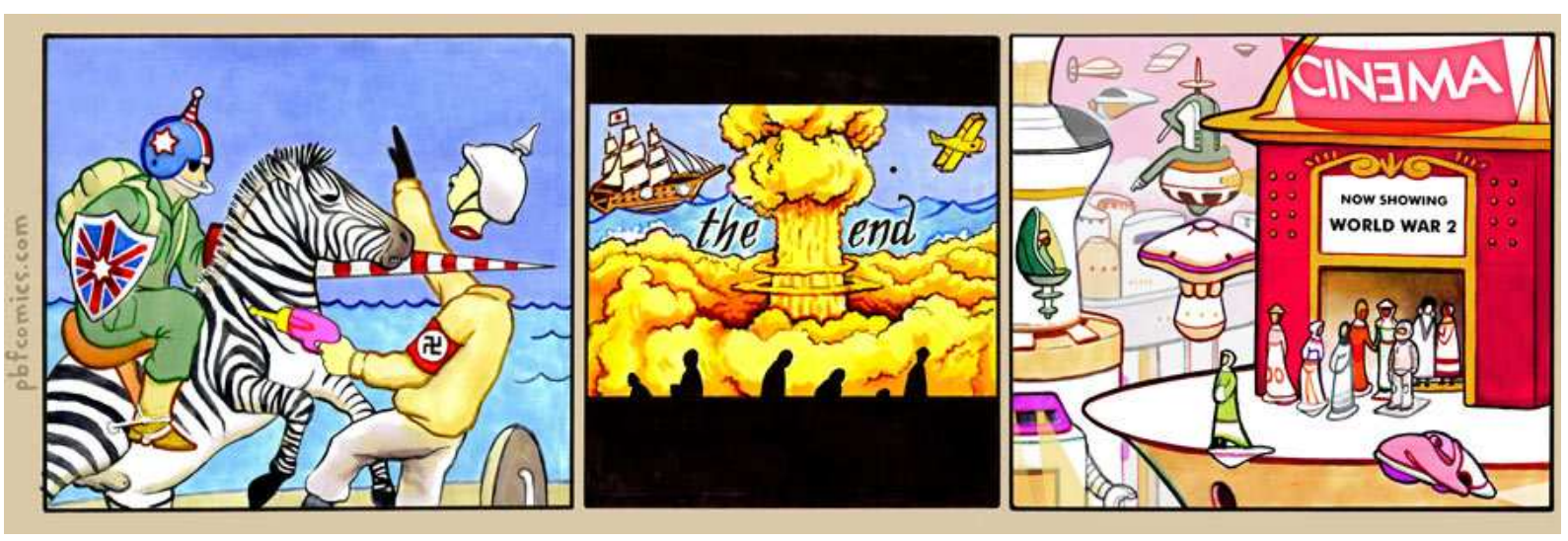

Fonte: http://pbfcomics.com/?cid=PBF209-Now_Showing.jpg. Último acesso em 12/11/2008.

\section{Poesia homérica: tradição oral > fonte textual}

Talvez seja oportuno iniciar este capítulo conclusivo observando de relance como se constituiu o texto homérico que temos hoje. Ele deriva de uma edição encontrada em papiros de época romana que datam entre 150 a.C. e o século VII d.C., além de alguns códices medievais escritos entre 900 e 1550 d.C. Em torno de 150 a.C., Aristarco, responsável pela Biblioteca de Alexandria, extirpou os versos presentes em manuscritos mais antigos que ele julgou posteriormente adicionados (JANKO, 1992, vol. 4, p. 20-38). O status dos textos antes de 150 a.C. é mais obscuro e é objeto de intensos debates que se dividiram em dois modelos: o que tem sido denominado "oral dictation" de um lado e os modelos "evolucionários" de outro. O primeiro defende que os textos que herdamos são registros confiáveis de uma recitação oral por um bardo para um escriba em algum momento durante o século VIII a.C. e que esse bardo (ou talvez um de seus predecessores) era Homero. Milman Parry (1987 [1971], p. 451) e Janko (1992) são alguns dos estudiosos que compartilham dessa teoria. O modelo evolucionário, por sua vez, propõe que os nossos textos sejam o produto de longos períodos de fluidez oral e transmissão textual, gradualmente cristalizantes (na terminologia de Nagy), entre o século VIII e o VI a.C., antes de receberem sua forma essencial sob o domínio de Pisístrato em Atenas durante o século VI a.C, mas fixado apenas no final do Período Clássico e início do Helenístico. "Homero" então seria um termo que expressa uma 
coletividade formada por aqueles envolvidos no processo de cristalização dos poemas (Graziosi, 2002).

Por um lado, a teoria evolucionária explicaria a popularidade das cenas homéricas na pintura vascular do século VI a.C., as diferenças entre os nossos textos e algumas citações atribuídas a Homero em autores clássicos, as várias versões textuais disponíveis aos editores alexandrinos e os aticismos (formas lingüísticas tardias) presentes no texto homérico. Por outro lado, os argumentos da "oral dictation" baseiam-se em quatro pontos: a unidade das narrativas, a unidade do tempo, a unidade da caracterização e o uso de artifícios como "flashbacks" e antecipações, compondo uma unidade coesa que impressionava até mesmo Aristóteles (Poética, 1448a-1459b); se o texto tivesse sido tardiamente estabelecido, as inconsistências no interior dos poemas (ou os "cochilos" homéricos, como Horácio os qualificou em sua Arte Poética, 359) teriam sido corrigidas pelos editores antigos, e os termos jônicos e eólicos teriam sido substituídos por formas áticas onde não houvesse prejuízo de sentido ou de métrica.

Embora as duas posições sejam antagônicas em relação a alguns aspectos da poesia homérica, ambas assumem que ela tem sua origem na tradição oral e posterior fixação escrita, que ela reflete vários estratos cronológicos sob aspectos dialetais e de estruturas sociais.

\section{Fonte textual $\mathrm{X}$ fonte material ou fonte textual $\mathrm{\cap}$ fonte material ${ }^{1}$}

M.I. Finley, em seu O Mundo de Ulisses (1982), deixou bem clara a sua posição em relação aos poemas homéricos: ainda que houvesse ataques a Tróia durante a Idade do Bronze, a natureza e a identidade dos combatentes certamente não teriam sobrevivido aos séculos de transmissão oral. Essa visão da poesia homérica é, em grande parte, conseqüência da comparação com a Canção de Rolando, épico francês, em que um pequeno incidente foi transformado pelos bardos numa batalha decisiva (onde Carlos Magno está com 200 anos!), e a Canção dos Nibelungos, épico germânico, em que os personagens principais são separados por

\footnotetext{
${ }^{1} \mathrm{O}$ símbolo ' $\mathrm{n}$ ' é a representação na matemática da idéia de 'intersecção'.
} 
gerações. Ele também afirmou que a sociedade descrita por Homero nada tem a ver com a sociedade dos palácios micênicos. Outros homeristas defendem que a sociedade apresentada pelos épicos homéricos corresponde à sociedade contemporânea a ele, ou seja, os séculos VIII e VII a.C. Evidentemente, a llíada e a Odisséia coseram narrativas preexistentes, talvez originadas em vários períodos, ou reinterpretaram versões conflitantes de uma expedição, o que estaria em pleno acordo com o que acontece na Canção dos Nibelungos. ${ }^{2}$

De qualquer maneira, as questões sobre a natureza da memória histórica que a épica nos coloca também permeiam o interesse gerado pelas descobertas arqueológicas. Estas revelaram os vários estratos cronológicos presentes na narrativa homérica: os Períodos Pré-Palacial, Palacial, Pós-Palacial, ProtoGeométrico, Geométrico, e até mesmo Orientalizante e Arcaico (VAN WEES, 2005), e, com isso, mostraram que a imaginação poética não pode ser confinada aos limites da história.

O início do capítulo 1 mostrou como os registros antigos dataram a Guerra de Tróia. Heródoto a coloca em torno de 1250 a.C., o Mármore de Paros em 1209 a.C. e Eratóstenes em 1183 a.C. Korfmann, o último escavador de Tróia, como vimos no capítulo 2, sugere os anos entre 1200 e 1180 a.C., em conformidade com a data oferecida por Eratóstenes. Teria a forma épica se originado antes ou depois disso? Uma linha argumentativa defende a origem da épica relacionada ao período imediatamente anterior ou imediatamente posterior ao Período Palacial (c. 14001200 a.C.), baseando-se no desconhecimento por parte da épica da burocracia palacial e seus oficiais, da escrita administrativa, das práticas funerárias, da especialização das indústrias palaciais, do desconhecimento dos termos usados para os trabalhadores especializados nos tabletes em Linear B, da produção para a exportação, enfim, o desconhecimento de aspectos do Período Palacial Micênico dos séculos XIV e XIII a.C. Mas seriam esses aspectos pertinentes à narrativa épica?

\footnotetext{
${ }^{2}$ Para questões de composição da épica, ver Bowra, 1952; Page, 1959; Kirk, 1962; Bowra, 1972.
} 
Há ainda os argumentos que envolvem as inconsistências entre os aspectos práticos do padrão de medida utilizado em Homero, em que o valor é medido em número de bois como, por exemplo, as armas em ouro de Glauco valerem 100 bois enquanto as armas de bronze de Diomedes valerem 9 bois (Ilíada, VI.234-236), e sua incompatibilidade com o sistema administrativo nos palácios micênicos. Este sistema não encontra paralelos na administração palacial refletida nos tabletes em Linear B. Talvez esta passagem em Homero caracterize apenas uma demonstração de possível equivalência de valores (cuja finalidade é simplesmente proporcionar ao ouvinte uma idéia mais palpável do embuste envolvido na troca das armas), e não a expressão de um equivalente universal de troca quer durante o Período Micênico quer durante a Idade do Ferro.

Um argumento em defesa da origem da épica ser anterior ao Período Palacial é composto pelas cenas de cerco a cidades muradas representadas no afresco de Thera, em vasos em metal (ver cap. 4, prancha Arco e Flecha, fig. AF2), em pedra e também em selos datados do início do Período Micênico (MORRIS, 1989). Evidentemente, cercos a cidades muradas não eram exclusividade desse período. Mas alguns dos itens do equipamento militar como o escudo em torre, o elmo em presa de javali, espadas com rebites em prata descritos na llíada encontram correspondências em achados do início do Período Palacial.

O uso de expressões que teriam sua origem muito anterior a Homero tem sido objeto de análises lingüísticas que tentam determinar as origens das narrativas épicas posteriormente incorporadas na épica homérica e, assim, quando precisamente uma narrativa celebrando uma expedição contra Tróia foi cantada em hexâmetro pela primeira vez.

Evidentemente, um horizonte que atinja os séculos XVI ou XV a.C. para a origem da épica homérica seria inconsistente em relação à posterior movimentação de povos no interior da Grécia por três gerações após a Guerra de Tróia, incluindo a chegada dos dórios no Peloponeso. 
Assim, embora alguns elementos dos poemas homéricos possam ter sua origem no Período Micênico, ou até mesmo em períodos mais antigos, ${ }^{3}$ tais poemas devem ser contextualizados na Idade do Ferro.

Se a tradição épica já existia durante o Período Micênico (1500-1100 a.C.), ela atravessou a Idade Obscura (1100-760 a.C.), foi certamente cantada no século VIII a.C. e fixada na forma escrita em uma data posterior, talvez no século VI a.C. sob Pisístrato. Em cada uma de suas performances muito provavelmente ela não era cantada exatamente da mesma maneira, ${ }^{4}$ e assim se sucedeu até a sua escrita. Portanto, Homero é mais do que o nome de um indivíduo (NAGY, 1979, p. 297-300, para quem a palavra Homeros significa 'aquele que junta [as canções]'), é a denominação de uma tradição de poesia épica oral que culminou na llíada e na Odisséia.

\section{As expectativas arqueológicas em relação ao poema homérico: passado, presente e futuro}

As grandes viagens à Grécia iniciadas durante o século XVII alcançaram seu auge na segunda metade do século XVIII com a redescoberta do mundo antigo no contexto da Europa lluminista. Então, muitos de seus monumentos eram tangíveis apenas pela imaginação alimentada pelos relatos de visitantes anteriores e de documentos antigos. A busca pela antiguidade começou como uma busca pelo desvelamento e logo se tornou um empreendimento de apropriação. Desde esses viajantes, passando pelos colecionadores de tesouros até as primeiras escavações arqueológicas, o passado ressurgia revelando epifanicamente o lar ancestral da civilização ocidental. Apesar das dificuldades associadas com a organização de um novo estado, a Grécia tentava proteger seus tesouros arqueológicos através da criação do Serviço Arqueológico (1833) e da Sociedade Arqueológica de Atenas (1837). Ao mesmo tempo, escolas estrangeiras estabeleciam suas fundações em

\footnotetext{
${ }^{3}$ Coldstream, 1977, p. 341-6; Morris, 1989; Page, 1959, p. 222-230; Parry, 1971; Nilsson, 1919, 34-41; Nilsson, 1932, passim.

${ }^{4}$ Como mostraram os estudos de Parry (1971) sobre a canção servo-croata.
} 
Atenas e recebiam direitos a escavações, pois o governo da Grécia não dispunha de fundos suficientes para explorar o seu próprio território.

As escavações em Hissarlik deixaram de ser a perseguição de uma imagem concebida por um poeta, para constituir um dos sítios mais importantes da arqueologia da região da Anatólia, tirando a exclusividade de Homero como fonte, e transformando-a em uma fonte de informação suplementar. Mas quais as conseqüências de se tratar a llíada como fonte histórica? Desde as descobertas de Schliemann, que revelaram não só tesouros, mas também a Pré-história e a Protohistória egeanas, a arqueologia da Idade do Bronze pode ser reconstituída em termos de basicamente três tradições epistemológicas: primeiro, uma visão "épica" dessa era, ou seja, como uma verificação arqueológica de Homero (e foi precisamente esta que deu origem ao termo "Arqueologia Homérica"); segundo, um interesse na "objetividade" histórica através do estudo "científico" dos dados materiais ao invés de se basear no testemunho literário; terceiro, a possibilidade de objetividade e de uma única verdade arqueológica estar posta em cheque pelas reflexões críticas sobre a natureza e o escopo da disciplina.

As escavações recentes em Tróia coordenadas por Manfred Korfmann da Universidade alemã de Tübingen estabeleceram uma duração de dois mil anos (3000-1000 a.C.) para Tróia como um centro comercial na Anatólia. O conhecimento dessa história talvez permanecesse enterrado para sempre no monte de Hissarlik na atual Turquia, não fosse um poema datado cerca de 300 anos após a data estabelecida para o seu fim. Mas seria essa cidade a mesma cidade cantada por Homero? A arqueologia ainda não pôde provar a Guerra de Tróia em termos absolutos: não há qualquer evidência escrita da ldade do Bronze que possa dizer "Aqui está Tróia” ou "A Guerra de Tróia aconteceu aqui nesta data". Por outro lado, seria muita coincidência a existência de uma cidade exatamente na localização indicada pela llíada e corroborada pela tradição posterior; portanto, seria um ceticismo infrutífero descartar a cidade encontrada por Schliemann como uma possibilidade de ser Tróia.

A idéia da continuidade de uma mesma identidade cultural para os habitantes dos palácios do Período Micênico e os habitantes da Grécia do século VIII a.C. 
encontra no deciframento da Linear B o seu maior argumento. Mas o vocabulário institucional dos tabletes em Linear $B$, apesar da existência de termos que se encontram na épica homérica, representa uma organização política bastante diferente. Mas até que ponto a continuidade lingüística compreende e reflete a continuidade de outros aspectos culturais de uma sociedade como seus hábitos, religião, comércio ou conhecimento técnico? Karl Joachim-Hölkeskamp (apud LATACZ, 2004, p. 165-166) disse que o colapso do sistema palacial micênico e suas conseqüências não resultaram numa ruptura abrupta e definitiva porque não refletiram diretamente nas estruturas subjacentes como as técnicas de manufatura, os hábitos alimentares, as relações comerciais, o transporte, a comunicação, a atribuição de nomes de divindades ou a religião. As mudanças ocorridas entre o século XV e o século VIII a.C. de caráter econômico, demográfico, social e político seriam aquelas que se poderiam esperar de qualquer povo durante o curso de muitos séculos, numa mesma área de habitação.

Snodgrass (2000 [1971], p. 28-9) percebe essas mudanças de maneira diferente. O século $\mathrm{XI}$ a.C. marca a passagem da Idade do Bronze para a Idade do Ferro, que pode ou não ser igualada ao início da Idade Obscura. $O$ fato é que esse período foi precedido pela época micênica, caracterizada principalmente pelo sistema palacial. Esse sistema se desintegrou no século XI junto com a escrita, ${ }^{5}$ mas o estilo e decoração da cerâmica continuaram nos moldes da tradição micênica, e um número substancial de assentamentos micênicos continuou a ser habitado; as práticas funerárias de enterramento em Túmulos em Câmara persistem, embora mais raramente nas thóloi; os ornamentos tradicionais das vestimentas micênicas e as figurinhas femininas em argila ainda são encontrados. A partir disso, a conclusão de Snodgrass é que 'a cultura micênica, embora moribunda, ainda não morreu'. Apesar da continuidade desses aspectos internos da civilização micênica, junto com

\footnotetext{
${ }^{5}$ Apesar da escrita Linear B ter desaparecido do continente, a ilha de Chipre conservou a escrita linear "sobretudo a partir do século IX até o século III a.C., tendo servido para conotar tanto a língua local - o eteocipriota - quanto o grego cipriota.” (SARIAN, 1998/1999, p. 159). Vale notar que a adaptação do alfabeto fenício, unicamente consonantal, para representar de forma escrita a língua grega teve como intermediário o silabário cipriota, remanescente do silabário cretense, "onde, precisamente, subsistem, a partir do modelo micênico, as cinco vogais introduzidas no alfabeto grego.” (Ibidem, p. 163).
} 
o sistema palacial e a escrita Linear B também desapareceram as referências em documentos hititas e egípcios.

Snodgrass mostra que, após as destruições dos palácios micênicos no final do século XIII (c. 1200 a.C.), aquela população responsável por aquela cultura permaneceu lá. A região da Argólida, centro da cultura micênica, foi a região que mais sofreu com as destruições, mas também se recuperou de maneira mais sólida: embora Micenas tenha deixado de ser habitada, Argos e Asine, outros dois grandes centros dessa região, continuaram a ser habitados. Mesmo Tirinto, que se pensava ter-se extinguido completamente com a destruição de c. 1200 a.C., apresenta um assentamento considerável datado do Micênico III C.

Outras áreas da Grécia tiveram outra experiência: na região da Acaia, na ilha de Kephallenia, no leste da Ática, nas Cíclades e no Dodecaneso há sinais de aumento da população micênica no século XII, talvez causado pela incursão de refugiados de áreas mais turbulentas.

Mas quando o elemento do novo e do desconhecido, que marca o fim da cultura micênica, deve ser detectado? "A cultura micênica termina em diferentes momentos em diferentes áreas da Grécia" (Snodgrass, 2000 [1971], p. 31). As diferenças nas práticas funerárias parecem não compor uma linha segura, pois, como vimos no capítulo 3, a prática da inumação continuou para algumas regiões da Grécia, embora com restrições. Seria este fim marcado pela adoção do ferro em detrimento do bronze, que já marca em termos absolutos a Idade do Bronze e a Idade do Ferro? Ainda que se adote a utilização do ferro, as questões de qual fonte e qual é a seqüência dos eventos pelos quais o ferro alcançou a Grécia, contudo, permanecem.

Em contraposição à Idade Obscura está o 'Renascimento Grego': a adoção e adaptação do alfabeto fenício pelos gregos; a volta das figuras humanas na cerâmica; o início da pólis. O século VIII a.C. é referido como o período do 'Renascimento Grego' e atualmente acredita-se que o início desse 'renascimento' tenha se dado a partir das colônias gregas estabelecidas na região oriental do Egeu. A adoção do alfabeto fenício em torno de 800 a.C. e sua expansão para um sistema de 26 caracteres, o estabelecimento de rotas de comércio que abrangiam desde o 
Levante até a ilha de Ísquia, próxima a Nápoles, transformaram o Mediterrâneo em domínio grego (LATACZ, 2004, p. 150).

A história recente (dos últimos mil anos) da Grécia nos mostra que a sua anexação ao Império Turco-Otomano e a sua existência sob esse domínio, que durou desde o século XV até 1830, modificaram o modus vivendi daquele povo habitante da Península Balcânica, mas não apagaram sua memória e que, apesar das diferenças, a sua língua ainda é uma forma de grego. Igualar a Grécia atual à Grécia Antiga é cometer um anacronismo imperdoável nos moldes históricos; por outro lado, desvinculá-la totalmente de sua Antiguidade é negar a seu povo a existência de um passado e o direito à sua memória. Talvez, algo parecido se dê com o período da proto-história grega que se denomina "Idade Obscura". A Grécia do século VIII a.C. não é a mesma do século XV a.C. (ou do século XV d.C.), mas negar uma certa continuidade entre elas é privar os gregos do século VIII a.C. da memória de seu próprio passado ou do passado em si, quer ele seja heróico ou não.

Mesmo que Homero ambiente sua épica num passado distante e heróico, este precisa ser compreensível à sua audiência. Talvez os anacronismos cometidos por ele nada mais sejam do que elementos que conferiam à sua audiência uma atmosfera de autenticidade; uma audiência que, segundo se acredita, está localizada temporalmente no século VIII a.C e é à mentalidade dessa audiência a que ele se dirige.

Compartilho da idéia de Snodgrass de que a poesia homérica é um amálgama, uma combinação de elementos e práticas das eras pelas quais a tradição oral viajou. Como Hurwit (1994, p.19), concordo que o texto homérico, como um sítio arqueológico, é composto por vários estratos de camadas sobrepostas. E como acontece com as camadas arqueológicas, elas não são uniformes entre si, mas muitas vezes o depósito de uma é maior do que a outra.

O mundo expresso por Homero, e este sempre entendido como o resultado de uma tradição anterior, é sim um constructo literário, com tijolinhos de diferentes sociedades históricas. A sua intenção não pode ter sido documentar uma sociedade, mas representá-la de uma maneira plausível para a sua audiência. Para ele, a 
verossimilhança, conceito que não fugiu a Aristóteles em sua Póetica, não está na representação exata do passado ou na precisão documental.

Se a poesia homérica apresenta elementos de eras consecutivas e diferentes, por que não denominá-las todas de homéricas? No estado atual dos estudos homéricos e arqueológicos não é possível dizer se uma delas é mais 'homérica' do que as outras, e denominá-las todas homéricas é mantê-las sob o jugo de uma tradição oral que, a partir do momento em que foi escrita, passou a fazer parte de uma tradição literária, que mais lança sombras do que luzes sobre cada uma delas.

\section{A impertinência do termo "Arqueologia Homérica"}

A única Arqueologia Homérica possível é a arqueologia do texto homérico em duas acepções: a filológica, que abrange a recuperação e o estudo dos papiros e códices, e o estudo do texto homérico em si, camada por camada, com a finalidade de compreensão do texto. Há outras denominações, cuja pertinência não vem ao caso discutir aqui, mas por fazerem referência geográfica ou cronológica ou ainda identitária transcendem a ilusória unidade proporcionada por uma tradição poética.

Qual é, então, o papel que se deve esperar do arqueólogo que se propõe a estudar os poemas homéricos? Mais do que o simples e fundamental papel de mediador entre a poesia homérica e a compreensão dos seus elementos constituintes, ele deve ser também o mediador dos aspectos daquela cultura que não foram preservados pela fonte escrita.

Para utilizar os poemas homéricos a fim de reconstruir o passado, quer seja ele Micênico, Heróico, Obscuro ou contemporâneo a Homero, é necessário saber lidar com uma representação do passado como a da 'tirinha' que compõe a epígrafe do presente capítulo. A tradição épica que culminou nos poemas homéricos preservou os reis do Período Micênico como heróis de um passado glorioso; a preservação de elementos desse passado no interior de tal tradição nos dá acesso ao mesmo tempo à sociedade dentro da qual a poesia homérica permaneceu como o resultado de uma seleção e a uma visão fragmentária da sociedade à qual ela remete. A relação entre esse passado heróico e o momento histórico ao qual essa 
poesia pertence (séc. VIII-VII a.C.) se dá na tensão entre a representação do passado e a emolduração que se realiza no momento em que essa tradição se consolida. A poesia homérica como resultado de uma longa tradição interpreta o passado mantendo as contradições presentes na própria realidade que ela experimentava. 


\section{Bibliografia}

AHLBERG-CORNELL, G. Myth and Epos in Early Greek Art: Representation and Interpretation. Jonsered: Paul Aströms Förlag, 1992.

. Prothesis and Ekphora in Greek Geometric Art. Göteborg:

Paul Aströms Förlag, 1971.

ALCOCK, S. E. Tomb Cult and Post-Classical Polis. American Journal of Archaeology, v. 95, n. 3 (1991), p. 447-467.

ANTONACCIO, C. M. Contesting the Past: Hero Cult, Tomb Cult, and Epic in Early Greece. American Journal of Archaeology, v. 98, no. 3 (1994), p. 389-410,

. Archaeology of Ancestors: tomb cult and hero cult in early

Greece. Lanham, Maryland: Rowman and Littlefield, 1995.

ANTONOVA, I. (org.) The Gold of Troy: Searching for Homer's Fabled City. London: Thames and Hudson, 1996.

BAURAIN, C. Le Grecs et la Mediterranée Orientale. Des siècles obscurs à la fin de l'époque archaïque. Paris: Nouvelle Clio, 1997.

BÉRARD, C. L'Hérôon à la porte de l'Ouest. Berne: A. Francke, 1970.

BLEGEN, C. W. Excavations at Troy 1932. American Journal of Archaeology, v. 36, n. 4 (Oct. - Dec., 1932), pp. 431-51.

. Excavations at Troy 1933. American Journal of Archaeology, v. 38, n. 2 (Apr. - Jun., 1934), p. 223-48. 
. Excavations at Troy 1934. American Journal of Archaeology, v. 39, n. 1 (Jan. - Mar., 1935), p. 6-34.

. Excavations at Troy 1935. American Journal of Archaeology, v. 39, n. 4 (Oct. - Dec., 1935), p. 550-587.

. Excavations at Troy 1936. American Journal of Archaeology, v. 41, n. 1. (Jan. - Mar., 1937), p. 17-51.

. Tróia e os troianos. Tradução de Rodrigo Machado. Lisboa: Ed. Verbo, 1971 [1963]. . Post-Mycenaean deposit in chamber-tombs. Arch. Eph., 1, 1937, p. 277-310.

BOWRA, C.M. Tradition and Design in the lliad. Oxford: Clarendon Press, 1930. . Heroic Poetry. London: Macmillan, 1952. . E U K N H M IDES A X A I0 I. Mnemosyne, v. 14, n. 2, 1961, p. 97-110. . Homer. London: Duckworth, 1972.

BREMER, J.M.; DE JONG, I; and KALFF, J. (ed.). Homer, Beyond Oral Poetry. Recent Trends in Homeric Interpretation. Amsterdam: John Benjamins, 1987.

BUCHHOLZ, H.-G. \& KARAGEORGHIS, V. Prehistoric Greece and Cyprus: An Archaeological Handbook. London: Phaidon, 1973.

BURN, A. R. Dates in Early Greek History. The Journal of Hellenic Studies, v. 55, Part 2., 1935, p. 130-146. 
CALHOUN, G.M. "Classes and Masses in Homer", Classical Philology, 29, 1934, p. 192-208.

CARLIER, P. Homère. Paris: Librairie Arthème Fayard, 1999.

CARTER, J. B. \& MORRIS, S. P. (ed). The Ages of Homer: a Tribute to Emily Towsend Vermeule. Austin, 1995.

CHADWICK, J. The Decipherment of Linear B. New York and Melbourne: Cambridge University Press, 1995 [1958].

Homère: un menteur? Diogène 77, 1972, p. 3-18.

. El Mundo Micenico. Madri: Alianza, 1987.

. "Who were the Dorians?". La Parola Del Passato, 1976, p.103-117.

COINDOZ, M. Troie et la guerre: mythe ou réalité? Archaeologia, $n^{\circ} 220$, jan. 87, p. 56-64.

COLDSTREAM, J.N. Geometric Greece. Cambridge: Methuen, 1977.

Hero-cults in the age of Homer. Journal of Hellenic Studies, 96, 1976, p. 8-17.

COOK, J.M. The cult of Agamemnon at Mycenae. Geras Antoniou Keramopoulou. Athénes, 1953, p.112-118.

COURBIN, P. La guerre en Grèce à haute époque d'aprés de les documents archéologiques. Gnoli \& Vernant, 1968, p. 69-71. 
CRIELAARD, J.P. (ed.). Homeric Questions. Amsterdam, 1995.

DE JONG, I. Narrators and focalizers. The Presentation of the Story in the Iliad. Amsterdam, 1987.

DEMARGNE, P. Naissance de L'Arte Grèc. Paris: Gallimard, 1964.

DESBOROUGH, V. R. The Greek Dark Age. London: Ernst Benn Limited, 1972. . Protogeometric Pottery. Oxford: Clarendon Press, 1952. . The Last Mycenaean and their successors: c. 1200-1000 b.C. Oxford: Clarendon Press, 1964.

DICKINSON, O. Homer, the Poet of the Dark Age. Greece and Rome, 33 (1986), p. 20-37.

FINLEY, M. O Mundo de Ulisses. Trad. Armando Cerqueira. Lisboa: Ed. Presença, 1982.

FORTENBERRY, D. Single Greaves in the Late Helladic Period. American Journal of Archaeology, v. 95, n. 4. (Oct., 1991), p. 623-627.

FOWLER, R. (ed.). The Cambridge Companion to Homer. Cambridge: Cambridge University Press, 2004.

GNOLI, G; VERNANT, J.-P. (dir.). La mort, le morts dans les sociétés ancienes. Cambridge/Paris, 1982. 
GRAZIOSI, B. Inventing Homer: The Early Reception of Epic. Cambridge: Cambridge University Press, 2002.

GRIFFIN, J. Homer on Life and Death. Oxford: Clarendon, 1980.

HÄGG, R. (ed.). The Greek Renaissance of the Eighth Century B.C.: Tradition and Innovation. Proceeedings of the Second International Symposium at the Swedish Institute in Athens, 1-5 June, 1983. Stockholm, 1983.

. Submycenaean Cremation Burials in the Argolid?. Laffineur, R. (ed.) Thanatos: Les Costumes Funeraires en Egee a L'Age du Bronze. Aegeum 1, 1987.

\& MARINATOS, N. (ed.). Sanctuaries and Cults in the Aegean Bronze Age. Proceedings of the First International Symposium at the Swedish Institute in Athens, 12-13 May, 1980. Stockholm, 1981.

HAMMOND, N. G. (ed.). Atlas of the Greek and Roman World in Antiquity. New Jersey: Noyes Press, 1981.

HURWIT, J. M. Art, Poetry, and the Polis in the Age of Homer. Langdon, S. (ed.). From Pasture to Polis: Art in the Age of Homer. Columbia and London: University of Missouri Press, 1994.

JANKO, R. The lliad: a Commentary, vol. 4: books 13-16. Cambridge: Cambridge University Press, 1992.

JOHANSEN, K. F. The lliad in Early Greek Art. Copenhagen, 1967.

KANNICHT, R. Poetry and Art: Homer and the Monuments Afresh. Classical Antiquity 1, n. 1, april 1982, p. 70-86. 
KARAGEORGHIS, V. Salamis in Cyprus: Homeric, Hellenistic and Roman. Great Britain: Thames and Hudson, 1969.

KING, C. The Homeric Corslet. American Journal of Archaeology, v. 74, n. 3, Jul., 1970, p. 294-296.

KIRK, G. S. The Songs of Homer. Cambridge: Cambridge University Press, 1962.

. The Homeric Poems as History. The Cambridge Ancient History. Vol. II, Part 2. Cambridge, 1982, p. 820-850.

KURTZ, D.C.; BOARDMAN, J. Greek burial customs. London, 1971.

LANGDON, S. (ed.). New Light on Dark Age: Exploring the Culture of Geometric Greece. Columbia, Missouri/London, 1997.

LATACZ, J. Troy and Homer: Towards a Solution of an Old Mystery. Oxford: Oxford University Press, 2004 [2001].

LEAF, W. Strabo on the Troad. Cambridge: Cabridge University Press, 1923.

LECHEVALIER, J.B. Description of the Plain of Troy: with a Map of that Region. Londres, 1791.

Les Mycéniens: Des Grecs du Ile millénaire, Editions Fatons, Dijons, 1994 (obra coletiva).

LORIMER, H. L. Homer and the Monuments. London: Macmillan \& Co.LTD, 1950.

LUDWIG, E. Schliemann : Storia d'un Cercatore d'Oro. Verona, 1932. 
MACKENDRICK, P.L. The Greeks Stones Speak: The History of archaeology in Greek Lands. London: Methuen \& Co Ltd, 1962.

MAHAFFY, J.P. The Site and Antiquity of the Hellenic llion. The Journal of Hellenic Studies, v. 3., 1882, p. 69-80.

MÖLLER, A. Epoch-making Eratosthenes. Greek, Roman, and Byzantine Studies 45, 2005, p. 245-260.

MONTANARI, F. Les poèmes homériques entre réalité et fiction. Em Gaia 9, 2005, p. 9-24.

MORRIS, I. The Archaeology of Ancestors: The Saxe-Goldstein Hypothesis Revisited. Cambridge Archaeological Journal 1:, 1991, p. 147-169.

\& POWELL, B. (ed.). A New Companion to Homer. Leiden/New York/Cologne, 1997.

MORRIS, S. P. A Tale of Two Cities: The Miniature Frescoes from Thera and the Origins of Greek Poetry. American Journal of Archaeology, vol. 93, 1989, p. 511-535.

MUSTI, D. (org.) La transizione dal miceneo all'alto arcaismo: dal palazzo alla città. Roma: Consiglio Nazionale delle Ricerche, 1991.

MYLONAS, G. E. Ancient Mycenae: The Capital City of Agamemnon. New Jersey: Princeton University Press, 1957. . Mycenae: A Guide to Its Ruins and Its History. Athens: Ekdotike Athenon S.A., 1985.

MYRES, J. L. On the 'List of Thalassocracies' in Eusebius. The Journal of Hellenic 
Studies, v. 26, 1906, p. 84-130.

NAGY, G. The Best of the Achaeans: Concepts of the Hero in Ancient Greek Poetry. John Hopkins University Press, 1979.

NILSSON, M. The Mycenaean Origin of Greek Mythology. Cambridge, 1932. . Homer and Mycenae. New York: Cooper Square Publishers, Inc., 1993 (1968).

PAGE, D. History and the Homeric lliad. Berkeley, 1959.

PAPAJATSIS, N. Micenas-Epidauro-Tirinto-Nauplia. Ediciones Clio, Atenas, 1986.

PARRY, M. The Making of Homeric Verse: the Collected Papers of Milman Parry. Edited by Adam Parry. New York: Oxford University Press, 1987 [1971].

POPHAM, M. R.; SACKET, L .H.; THEMELIS, P.G. (org). Lefkandi I. The Iron Age. London, 1980.

PRICE, T. H. Hero-cult and Homer. Historia 22, 1973, p. 129-143.

ROMILLY, J. De. Homère. Col. Que sais-je? Paris: PUF, 1985.

Perpectives Actuelles sur l'epopée Homerique. Paris: Presses Universitaires de France, 1983, p. 5-41.

RUNNELS, C. The Archaeology of Heinrich Schliemann: An Annotated Bibliography Handlist. Boston: Archaeological Institute of America, 2002. 
SAGE, M. Warfare in Ancient Greece: a Sourcebook. London and New York: Routledge, 1996.

SANDARS, N. K. The First Aegean Swords and Their Ancestry. American Journal of Archaeology, v. 65, n. 1, (Jan., 1961), p. 17-29.

. Later Aegean Bronze Swords. American Journal of Archaeology, v. 67, n. 2, (Apr., 1963), p. 117-153.

SARIAN, H. La Civilization. Em Treuil, 1989, p. 585-593.

. Culto Heróico, Cerimônias Fúnebres e a Origem dos Jogos Olímpicos. Clássica, v. 9/10, 1996-1997, p. 34-44.

A Escrita Alfabética Grega: uma invenção da pólis? A contribuição da Arqueologia. Clássica, v. 11/12, 1998-1999, p. 159-177.

SCHAEFFER, C. F.-A. Stratigraphie comparée et chronologie de l'Asie occidentale : (3e et 2e millénaires). London: Oxford University Press, 1948.

SCHLIEMANN, H. Ítaca, o Peloponeso e Tróia: pesquisas arqueológicas. São Paulo: Ars Poética, 1992 [1868].

Troy and Its Remains. New York: Dover Publications, Inc., 1994 [1875].

Mycenae: A Narrative of the Researches and Discoveries at Mycenae and Tiryns. New York: Arno Press, 1976 [1880].

Ilios: The City and the Country of the Trojans. New York: Arno Press, 1976 [1881]. 
SCHNAPP-GOURBEILLON, A. Les Funerailles de Patrocle. Em Gnoli \& Vernant, 1982, p. 77-88.

SCULLY, S. Homer and the Sacred City. Ithaca, 1990.

SHEFOLD, K. Myth and Legend in Early Greek Art. London: Thames and hudson: 1966.

Gods and Heroes in late Archaic Greek Art. Cambridge, 1992.

SHERRATT, E. S. 'Reading the texts': archeology and the Homeric question. Antiquity 64 (1990), p. 807-824.

SNODGRASS, A. The archaeology of Greece. The Present and the Future of a Discipline, University of California Press, 1987.

. Early Greek Armour and Weapons: from the end of Bronze Age to 600 b.C. Edinburgh: University Press, 1964.

Arms and Armour of the Greeks. London and Southampton: Thames \& Hudson, 1967.

. The Dark Age of Greece: An Archaeological Survey of the Eleventh to Eighth Centuries B.C. Edinburgh: University Press, 2000 (1971).

Homero e os Artistas: Texto e pintura na Arte Grega Antiga. São Paulo: Odysseus, 2004 [1998].

. Poet and Painter in Eighth-Century Greece. Proceedings of the Cambridge Philological Society, n. 205 (New Series No. 25), 1979, p.118-130. 
. Les origines du culte des héros dans la Grèce antique. Gnoli \& Vernant (dir.), $1982,107-119$.

SPENCER, T. J. B. Robert Wood and the Problem of Troy in the Eighteenth Century. Journal of the Warburg and Courtauld Institutes, v. 20, n. 1/2. (Jan. - Jun., 1957), p. 75-105.

SOUZA, C. D. Estruturas e Artefatos: o culto heróico em sítios gregos da ldade do Ferro (séc. XI ao VIII a.C.). Dissertação de Mestrado, Universidade de São Paulo, 2005.

STUBBINGS, F. H. Prehistoric Greece. New York: The John Day Co., 1973.

SYMEONOGLOU, S. A Chart of Mycenaean and Late Minoan Pottery. American Journal of Archaeology, v. 74, n. 3 (Jul., 1970), p. 285-288.

TANDY, D. W. Warriors into Traders. Berkeley, Los Angeles, London: University of California Press, 1997.

TAYLOUR, W. Os Micênios. Lisboa: Ed. Verbo, 1973.

THOMAS, R. Literacy and orality in Ancient Greece. Cambridge: Cambridge University press, 1992.

TORRALVO, A. C. As dimensões sociais dos costumes funerários entre os micênios. Dissertação de Mestrado, Universidade de São Paulo, 1993.

TREUIL, R. (ed.). Les Civilisations Égéennes du Néolithique e de l'Age du Bronze. Paris: Presses Universitaires de France, 1989. 
TSOUNTAS, C. The Mycenaean Age: A Study of the Monuments and Culture of PreHomeric Greece. Boston and New York: The Riverside Press, 1897.

VAN WEES, H. Greek Warfare: Myths and Realities. London: Duckworth, 2004.

VERMEULE, E. T. The Mycenaeans in Achaia. American Journal of Archaeology, v. 64, n. 1 (Jan., 1960), p. 1-21.

Aspects of Death in Early Greek Art and pottery. Berkeley, 1979.

- Grecia en la Edad del Bronze. México, Fondo de Cultura

Económica, 1996.

VERNANT, J.-P (dir.). Problèmes de la Guerre en Grèce Ancienne. Paris, La Haye: Mouton, 1968.

WACE, A. J. B. The Date of the Treasury of Atreus. The Journal of Hellenic Studies, v. 46, Part 1 (1926), p. 110-120.

Mycenae, 1939. The Journal of Hellenic Studies, v. 59, Part 2, 1939,

p. $210-212$.

. Mycenae: An Archaeological History and Guide. Princeton, 1949.

Notes on the Homeric House. The Journal of Hellenic Studies, v.

71. (1951), p. 203-211.

\& STUBBINGS, F.H. (ed.). A companion to Homer. London, 1962.

WATHELET, P. Les Troyens de l'lliade. Mythe et histoire. Liège-Paris, 1989. 
WEBSTER. T. B. L. La Grèce de Mycènes a Homère. Paris: Payot, 1962.

WEINER, M. H. The Absolute Chronology of Late Helladic III A 2 Revisited. Annual of the British School at Athens, 98 (2003), p. 239-250.

WHITLEY, J. Style and Society in Dark Age Greece. New York: Cambridge University Press, 1991.

WOOD, M. In Search for the Trojan War. Penguin Books / BBC Books, London, 1996 [1985].

ZERVOS, C. La Civilisation Hellénique (Tome I, XI-VII S.) Paris: Ed. Cahiers D’Art, 1969. 


\section{Fontes Literárias}

CÍCERO. Em defesa do poeta Árquias. Introdução, tradução e notas de Maria Isabel Rebelo Gonçalves. Lisboa: Inquérito, 1986.

COUGNY, G. (org.) Epigrammatum anthologia palatina cum planudeis et appendice nova epigrammatum veterum ex libris et marmoribus. Paris: Firmin-Didot, 1927.

DIODORUS OF SICILY (séc. I a.C.). Translated by C. H. Oldfather. 12 vols. The Loeb Classical Library. London, 1989 [1933].

FILOSTRATO. Philostratus: Life of Apollonius of Tyana. Translated by F. C. Conybeare. The Loeb Classical Lybrary. London/Cambridge: William Heinemann/Harvard University Press, 1948.

HERODIAN. 2 vols. Translated by C. R. Whittaker. The Loeb Classical Lybrary. Cambridge: Harvard University Press, 1970.

HERÓDOTO. Histoires, Livre II. Texte Établi et traduit par Ph.E. Legrand. Les Belles Lettres. Paris, 1982.

HESíODO. Os Trabalhos e os Dias. Tradução de Mary Lafer. São Paulo: lluminuras, 1990.

HOMERO. llíada. Tradução de Carlos Alberto Nunes. Ediouro, Rio de Janeiro, 1996. $6^{\underline{a}}$ edição.

. llíada. Vol. 1. Tradução de Haroldo de Campos. São Paulo: Mandarim, 2001.

. llíada. Vol.2. Tradução de Haroldo de Campos. São Paulo: ARX, 2002. 
HORACE. Oeuvres Completes I: Odes et Épodes. Éditions Garnier. Paris, 1950.

STRABO. Geography. Jones, P.V (ed.). Loeb Classical Library, Cambridge, Massachusetts: Harvard University Press, 1917-1932.

LUCAIN. La Guèrre Civile (La Pharsale). Tome II, Livre VI-X. Texte Établi et Traduit par A. Bourgery et M. Ponchont. Les Belles Lettres. Paris, 1948.

PLUTARCO. Alexandre, o Grande. Tradução de Hélio Vega. Rio de Janeiro: Ediouro, 2005.

SHACKLETON, B (org.). Anthologia Latina. Stuttgart: Teubner, 1982.

TÁCITO, Anales: libros I-VI. Tradução de Jose L. Moralejo. Madrid : Gredos, 1991.

TUCÍDIDES. História da Guerra do Peloponeso: Livro I. Tradução de Ana Lia Amaral. Texto grego estabelecido por Jacqueline de Romilly. São Paulo: Editora Martins Fontes, 1999. 


\section{Lista das figuras}

\section{Frontispícios}

Frontispício da Introdução: A apoteose ou deificação de Homero (1827). Quadro de Jean Auguste Dominique Ingres. Museu do Louvre Paris, INV 20039. Fonte da figura:

$<$ http://www.culture.gouv.fr/public/mistral/joconde fr>. Último acesso em 05/12/2008.

Frontispício do Capítulo 1: Capa do livro "The Hero Schliemann: The Dreamer who dug up Troy" de Laura Amy Schlitz e Robert Byrd. Candlewock Press, 2006. Fonte da figura:

$<$ http://www.greenleafpress.com/catalog/index.php?main page=popup image\&plD=1273\&zenid=183 d9c45c67254dd6e3bde87c86007c7>. Último acesso em 04/12/2008.

Frontispício do Capítulo 2: Manfred Körfmann em Tróia. Foto tirada em 2004. Fonte da foto: $<$ http://www.nytimes.com/imagepages/2005/08/19/international/19korfmann CA0.ready.html>. Último acesso em 01/12/2008.

Frontispício do Capítulo 3: Detalhe do quadro Funerais de Pátroclo (1778) de Jacques Louis David. Óleo sobre tela $(94 \times 218 \mathrm{~cm})$. National Gallery of Ireland, Dublin, Irlanda. Fonte da figura: $<$ http://www.vroma.org/ araia/patroklos.html>. Último acesso em 17/12/2008.

Frontispício do Capítulo 4: Vaso dos Guerreiros. Proveniente de Micenas (c. 1200 a.C.). Altura: 41 $\mathrm{cm}$. Museu Arqueológico Nacional de Atenas. Fonte da Figura:

$<$ http://bama.ua.edu/ ksummers/cl222/mycenae/mycenaen vase warriors large.jpg $>$. Último acesso em 29/11/2008.

Frontispício do Capítulo 5: Eric Shanower, criador de Age of Bronze, quadrinho que tem sido publicado desde 1998 e que reconta a Guerra de Tróia baseado na tradição literária e nos achados arqueológicos da Idade do Bronze Recente, está posicionado diante dos personagens, mas olhando para o leitor. O quadrinho Age of Bronze ganhou o prêmio Will Eisner Comics Industry de melhor escritor/artista em 2001 e 2003 e o prêmio Gran Guinigi de Melhor Quadrinho Seriado no Festival de Quadrinhos de Lucca, na Itália, em 2006. Fonte da figura:

$<$ http://age-of-bronze.com/aob/index.shtml>. Último acesso em 22/12/2008 .

\section{Figuras do Capítulo 1}

Fig. 1 Plano da Cidade de Tróia e seus arredores publicada em The lliad of Homer, II, 1716, p. 85, de Alexander Pope. Fonte: Spencer, 1957, 9a.

Fig. 2 Mapa da Trôade em An Essay on the Original Genius and Writings of Homer; with a comparative view of the ancient and present state of the Troad de Robert Wood, publicado em 1775, p. 87. Fonte: Spencer, 1957, 9b.

Fig. 3 Mapa da planície de Tróia publicado por M. Chevalier em 1785-6 em Transactions of the Royal Society of Edinburgh, III, 1794 (p.93). Fonte:

$<$ http://www.chs.harvard.edu/publications.sec/online print books.ssp/classics issue 3/burgess fig1.j pg>. Acesso em 11/11/2007.

Fig. 4: Hissarlik (Tróia), em 1873, vista norte. Trincheira norte-sul escavada por Schliemann. Fonte: Schliemann, 1976, p. 64.

Fig. 5: Visão geral do Tesouro de Príamo, quando de sua descoberta, em 1873. Fonte: $<$ http://www.detecting.org.uk/images/Priams2.jpg >. Acesso em 22/05/2007.

Fig. 6 Sophia, esposa de Schliemann, vestindo as jóias do Tesouro de Príamo. Fonte: $<$ http://home.att.net/ a.a.major/sophie.jpg >. Acesso em 11/11/2007.

Fig. 7 Objeto ovalado encontrado por Schliemann que ele relacionou ao a $\$ \mathrm{pij}$ o mf a I oks s a homérico. Museu Pushkin, Russia. Inventário P 359 A 5817. Fonte: $<$ www.yorku.ca/.../+3130\%202006/3130jan26-2006.htm> (detalhe). Acesso em 26/01/2006.

Fig. 8 Caldeirão de cobre encontrado por Schliemann que ele relacionou à l ebh h homérica. Fonte: <http://en.wikipedia.org/wiki/lmage:Priam\%27s_treasure.JPG> (detalhe). Acesso em 26/01/2006. Fig. 9 Molheira de ouro encontrada por Schliemann. Fonte da Imagem:

http://www.utexas.edu/courses/classicalarch/images2/troy2goldsauce.jpg. Acesso em 31/05/2007. 
Fig. 10 Visão geral da exposição do Tesouro de Príamo no Museu Pushkin, Rússia. Fonte: $<$ http://www.utexas.edu/courses/classicalarch/images2/Troy2gold2.jpg> Acesso em 29/05/2007. Fig. 11 Diagrama da sucessão de estratos em Hissarlik, estabelecido por Schliemann no final da primeira fase de escavações durante os anos de 1871-73. Fonte: Schliemann, 1994 [1875], p. 10. Fig. 12 Plano da cidadela de Tirinto publicado por Schliemann em Mycenae, 1976 [1880], Plan A. Fig. 13 Muro do lado sul de Tirinto. Fonte:

$<$ http://www.odysseyadventures.ca/articles/mycenae/tiryns casemates-south.htm >. Acesso em $11 / 11 / 2007$.

Fig. 14 Rampa de acesso a Tirinto construída sobre muros ciclópicos. Fonte:

<http://www.megalithic.co.uk/modules.php?op=modload\&name=a312\&file=index\&do=showpic\&pid=2 $3466>$. Acesso em 24/10/2007.

Fig. 15 Portal de entrada de Tirinto. Fonte:

$<$ http://www.megalithic.co.uk/modules.php?op=modload\&name=a312\&file=index\&do=showpic \&pid=2 3465>. Acesso em 24/10/2007.

Fig. 16 Vestígios de torre à direita do portal de entrada de Tirinto. Fonte:

<http://www.megalithic.co.uk/modules.php?op=modload\&name=a312\&file=index\&do=showpicpid=23 464>. Acesso em 24/10/2007.

Fig. 17 Galerias internas de Tirinto. Fonte: <http://www.derbiogrieche.de/drepanon/ganzalt.html>. Acesso em 24/10/2007.

Fig. 18 Algumas das figurinhas de animais e figurinhas femininas encontradas em Tirinto por Schliemann. Fonte: Schliemann, 1976 [1880], p. 10-12.

Fig. 19 Plano da acrópole de Micenas publicado por Schliemann em Mycenae, 1976 [1880], Plan C.

Fig. 20 Bastião à direita da Porta dos Leões, Micenas. Fonte:

$<$ http://wms.erudition.net/images/greece/mycenae/cyclopean wall1.jpg >. Acesso em 11/11/2007.

Fig. 21 Porta dos Leões, Micenas. Fonte:

$<$ http://employees.oneonta.edu/farberas/arth/Images/ARTH209images/Mycenaean/lions gate.jpg >. Acesso em 24/10/07.

Fig. 22 Postigo ogival que cruza o interior do muro de Micenas. Fonte:

$<$ http://www.odysseyadventures.ca/articles/mycenae/mycenae sallyport.htm>. Acesso em $26 / 06 / 2008$.

Fig. 23 Portão norte de Micenas. Fonte:

$<$ http://www.megalithic.co.uk/modules.php?op=modload\&name=a312\&file=index\&do=showpic\&pid=2 3254>. Acesso em 24/10/07.

Fig. 24 Dromos e porta de acesso ao Tesouro de Atreu, Micenas. Fonte:

$<$ http://employees.oneonta.edu/farberas/arth/Images/ARTH209images/Mycenaean/treas atreus entr .jpg >. Acesso em 24/10/07.

Fig. 25 Interior do Tesouro de Atreu, Micenas. Fonte:

<http://employees.oneonta.edu/farberas/arth/Images/ARTH209images/Mycenaean/treas atreus int.jp g>. Acesso em 25/10/2007.

Fig. 26 Figurinhas em terracota encontradas em Micenas por Schliemann. Fonte: Schliemann, 1976 [1880], Plate B e Plate C.

Fig. 27 Plano do Círculo Tumular Circular A e seus arredores, em Micenas, publicado por

Schliemann. Fonte: Schliemann, 1976 [1880], Plan B.

Fig. 28 Círculo Tumular A visto a partir da Porta dos Leões. Fonte:

$<$ http://employees.oneonta.edu/farberas/arth/Images/ARTH209images/Mycenaean/roy grav circ a.jp g>. Acesso em 25/10/07.

Fig. 29 Máscara de Agamêmnon. Fonte:

$<$ http://www.odysseyadventures.ca/articles/mycenae/article mycenae.htm>. Acesso em 11/11/07.

Fig. 30 Máscaras mortuárias em ouro encontradas no interior do Sepulcro IV do Círculo Tumular A, em Micenas. Fonte: Mylonas, 1985, p. 36.

Fig. 31 Ríton de ouro na forma de cabeça de leão, proveniente do Túmulo IV no interior do Círculo Tumular A. Fonte: <http://www.ou.edu/finearts/art/ahi4913/aegeanhtml/mycobj4.html>. Acesso em 27/06/2008.

Fig. 32 Diadema em ouro, proveniente do Túmulo III no interior do Círculo Tumular A. Fonte: $<$ http://www.ou.edu/finearts/art/ahi4913/aegeanhtml/mycobj4.html $>$. Acesso em 27/06/2008. 
Fig. 33 Plano do Túmulo Circular A com o Sepulcro VI descoberto por Stamatákis. Fonte: Tsountas, 1897, p. 86, fig. 33.

Fig. 34 Diagrama da sucessão de estratos em Hissarlik, estabelecido por Schliemann no final da segunda fase de escavações durante os anos de 1878-79. Fonte: Schliemann, 1976 [1881], p. vii.

\section{Figuras do Capítulo 2}

Fig. 1 Plano da Cidadela de Micenas com os monumentos revelados por Schliemann, Stamatákis e Tsountas. Fonte: http://www.varchive.org/schorr/mycenae.htm em 17/09/2008.

Fig. 2 Tsountas à entrada da cisterna em Micenas. Fonte da figura: Tsountas, pl. VII.

Fig. 3 Plano do Palácio de Micenas. Fonte da figura: Mylonas, 1985, p. 59.

Fig. 4 Canecas em ouro de Vaphio (1500-1400 a.C.). Provenientes de Vaphio, nas proximidades de Esparta. Altura: $8,9 \mathrm{~cm}$. Museu Arqueológico Nacional de Atenas. Fonte da figura:

$<$ http://images.encarta.msn.com/xrefmedia/sharemed/targets/images/pho/t014/T014535A.jpg >. Último acesso em 18/09/2008.

Fig. 5. Desenho do relevo das Canecas Vaphio. Fonte da figura:

$<$ http://www.mlahanas.de/Greeks/LX/VaphioCup2.jpg >. Último acesso em 18/09/2008.

Fig. 6 Plano da área de Micenas além da cidadela. Fonte da figura: Mylonas, 1985, p. 69.

Fig. 7 Píthoi no chão da Casa VII Theta. Tróia VIla. Fonte da imagem: Blegen, 1936, p.36.

Fig. 8 Plano do Círculo Tumular B. Fonte da figura:

http://www.odysseyadventures.ca/articles/mycenae/mycenae circle-b plan.htm. Último acesso em $14 / 12 / 2008$.

Fig. 9 Plano dos principais estratos da Cidadela ou cidade alta de Tróia. Fonte da figura: $<$ http://en.wikipedia.org/wiki/lmage:Plan Troy-Hisarlik-en.svg>. Último acesso em 13/11/2008.

Fig. 10 Reconstrução artística dos estratos de Tróia por Christoph Haussner. Fonte da Figura: $<$ http://www.utexas.edu/courses/introtogreece/lect4/img22troylvls.html >. Último acesso em $13 / 11 / 2008$.

Fig. 11 Tróia e seus arredores atualmente. A linha escura marca os limites do Parque Histórico Nacional de Tróia. Fonte da Figura: Latacz, 2004, p. 6.

Fig. 12 Níveis de estabelecimentos sobre Hissarlik estabelecido pela equipe de Korfmann (2000). Fonte da Figura: Latacz, 2004, p. 11.

\section{Figuras do Capítulo 3}

Fig. 1 Ânfora cinerária. (c. 860-840 a.C.). Museu Arqueológico do Cerâmico. Fonte da Figura: $<$ http://teachers.sduhsd.k12.ca.us/ltrupe/art\%20history\%20web/final/chap5Greece/CineraryAmphora.j pg>. Último acesso em 29/11/2008.

Fig. 2 'Taça de Nestor'. Kotile datada de c. 720 a.C. Proveniente do túmulo 168 da Necrópole do Valle de S. Montano. Museu de Villa Arbusto, Lacco Ameno, Ísquia.

Fonte da figura (kotile): http://upload.wikimedia.org/wikipedia/commons/a/ae/Coppa di Nestore.png em 29/11/2008. Fonte da figura (inscrição):

http://upload.wikimedia.org/wikipedia/commons/3/3c/Nestor Cup Cumae.jpg em 29/11/2008.

Fig. 3 Cratera Fragmentária atribuída ao Mestre do Dípilon utilizada como marcador tumular. (c. 750 a.C.). Altura: $58 \mathrm{~cm}$ (fragmento). Museu do Louvre, Paris. Número de Inventário: A 517. Fonte da Figura:

$<$ http://www.louvre.fr/llv/oeuvres/detail notice.jsp?CONTENT\%3C\%3Ecnt id =10134198673225197\& CURRENT LLV NOTICE\%3C\%3Ecnt id=10134198673225197\&FOLDER\%3C\%3Efolder id=985272 $3696500782 \&$ bmLocale=en>. Último acesso em 29/11/2008.

Fig. 4 Cratera Funerária proveniente do Cemitério do Dípilon, Atenas (c. 750-735 a.C.) atribuída ao Ateliê Hirschfeld. Altura: $108,3 \mathrm{~cm}$; diâmetro: $72,4 \mathrm{~cm}$. The Metropolitan Museum of Art, New York. Número de Inventário: 14.130.14. Fonte da Figura:

$<$ http://teachers.sduhsd.k12.ca.us/ltrupe/art\%20history\%20web/final/chap5Greece/VaseDipylon\%20Cemetary.jpg>. Último acesso em 29/11/2008. 


\section{Figuras do Capítulo 4}

\section{Prancha Cnêmides}

Fig. C1 Possíveis fivelas para segurar cnêmides, provenientes do Círculo Tumular A, encontradas por Schliemann durante a campanha de escavação em 1876. Cerca de 1550-1500 a.C. Fonte da figura: $<$ http://www.salimbeti.com/micenei/armour4.htm>. Último acesso em 11/04/2008.

Fig. C2 Ornamento de ouro entalhado com figura humana usando uma espécie de calção.

Encontrado por Schliemann no interior do sepulcro III do Círculo Tumular A durante a campanha de escavação de 1876. Cerca de 1550-1500 a.C. Fonte da figura:

$<$ http://www.salimbeti.com/micenei/armour4.htm>. Último acesso em 11/04/2008.

Fig. C3 Objeto de bronze, provável tornozeleira, encontrado na Câmara Tumular 15, em Micenas. Cerca de 1300-1250 a.C. Fonte da figura: <http://www.salimbeti.com/micenei/armour4.htm>. Último acesso em 11/04/2008.

Fig. C4 Cnêmide de bronze encontrada no interior do Túmulo 12 em Dendra, em 1960. Cerca de 1400 a.C. Fonte da figura: <http://www.salimbeti.com/micenei/armour4.htm>. Último acesso em $11 / 04 / 2008$.

Fig. C5 Cnêmide de bronze encontrada em Olímpia. Século VI a.C. $37 \mathrm{~cm}$ de altura. Fonte da figura: $<$ http://ccwf.cc. utexas.edu/ warfare/Lectures/lmages/2.9/04\%20archaic greave olympia.JPG>. Último acesso em 11/04/2008.

Fig. C6 Representação de fragmento de cnêmide encontrada no Túmulo "Sueco" 18 em Enkomi, Chipre, datado de cerca de 1200 a.C. Fonte da figura:

$<$ http://www.salimbeti.com/micenei/armour4.htm>. Último acesso em 11/04/2008.

Fig. C7 Fragmentos de cnêmides provenientes de Enkomi, Chipre, datadas de pouco depois de. 1200 a.C. Fonte da figura: <http://www.salimbeti.com/micenei/armour4.htm>. Último acesso em $11 / 04 / 2008$.

Fig. C8 Par de cnêmides proveniente do Túmulo do Guerreiro, em Kallithea, datadas do Heládico Tardio IIIC. Dimensões: $25,5 \mathrm{~cm}$ de altura and $12,6 \mathrm{~cm}$ de largura. Fonte da figura: $<$ http://www.salimbeti.com/micenei/armour4.htm>. Último acesso em 11/04/2008.

Fig. C9 Par de cnêmides proveniente de Câmara Tumular na face sul da Acrópole de Atenas datado do Heládico Tardio IIIC. Fonte da figura: <http://www.salimbeti.com/micenei/armour4.htm>. Último acesso em 11/04/2008.

Fig. C10 Fragmento de afresco do Mégaron de Micenas, datado entre LHIIIA e LHIIIB (1370-1350 a.C.). A figura humana representada numa queda usa um par de cnêmides que alcança os joelhos ou está usando, além das cnêmides, algum tipo de joelheira. Fonte da figura:

$<$ http://www.salimbeti.com/micenei/armour4.htm>. Último acesso em 11/04/208.

Fig. C11 Fragmentos de afresco do Mégaron de Micenas, datado entre LHIIIA e LHIIIB (1370-1350

a.C.). Fonte da figura: <http://www.salimbeti.com/micenei/armour4.htm>. Último acesso em $11 / 04 / 2008$.

Fig. C12 Fragmento de afresco da casa do Mercador de Óleo, Micenas, datado entre HRIIIA e HRIIIB (1370-1350 a.C.). Fonte da figura: <http://www.salimbeti.com/micenei/armour4.htm>. Último acesso em 11/04/2008.

Fig. C13 Fragmento de afresco de Pilos datado de 1300 a.C. Fonte da figura: $<$ http://www.salimbeti.com/micenei/armour4.htm>. Último acesso em 11/04/2008.

Fig. C14 Detalhe da Estela dos Guerreiros, proveniente de Micenas datado do Heládico Recente III. Fonte da figura: <http://www.salimbeti.com/micenei/armour4.htm>. Último acesso em 11/04/2008.

Fig. C15 Detalhe do Vaso dos Guerreiros, proveniente de Micenas datado do século XII a.C. Fonte da figura: <http://www.salimbeti.com/micenei/armour4.htm>. Último acesso em 11/04/2008.

Fig. C16 Fragmento do "Vaso do Noivo", proveniente de Micenas, datado do Heládico Recente III. Fonte da figura: <http://www.salimbeti.com/micenei/armour4.htm>. Último acesso em 11/04/2008. Fig. C17 Fragmento cerâmico proveniente de Micenas, datado do Heládico Recente III. Fonte da figura: <http://www.salimbeti.com/micenei/armour4.htm>. Último acesso em 11/04/2008.

Fig. C18 Vaso Chigi, enócoa em estilo Proto-coríntio proveniente da Etrúria datada de c.620 a.C. Fonte da figura: <http://www.utexas.edu/courses/introtogreece/lect10/img10chigivase.html>. Último acesso em 11/04/2008. 


\section{Prancha Armadura e Corselete}

Fig. AC1. Armadura em bronze com elmo em dentes de javali. Proveniente de Dendra, Argólida. Cerca de 1425 a.C. Fonte da figura: Papajatsis, 1986, p. 23.

Fig. AC2. Cinco chapas de bronze datadas de cerca de 1500 a.C. provenientes de Archalachori, em Creta. As dimensões são, respectivamente, $15 \mathrm{~cm}$ de diâmetro para a maior delas, $10 \mathrm{~cm}$ para a média e 5-6cm para as três menores. Pequenas perfurações, que não podem ser observadas através dessa imagem, existem no em torno das chapas e poderiam ser usadas para a sua fixação ao corselete em material perecível. Fonte da figura: <http://www.salimbeti.com/micenei/armour2.htm>. Último acesso em 23/10/2008.

Fig. AC3. Ideogramas em Linear B de tabletes de Knossos que correspondem a armaduras ou corseletes. Fonte da figura: <http://www.mlahanas.de/Greeks/war/Armor/arm1.jpg>. Último acesso em 20/10/2008.

Fig. AC4. Corselete em bronze. Proveniente de Argos. Cerca de 725 a.C. Dimensão: $49 \mathrm{~cm}$ de altura. Fonte da figura: <http://www.mlahanas.de/Greeks/war/Armor/arm1.jpg>. Último acesso em 20/10/2008.

\section{Prancha Elmo}

Fig.E1 Elmo em dentes de javali (reconstruído). Micenas. Século XVI a.C. Fonte da figura: $<$ http://www.salimbeti.com/micenei/helmets2.htm>. Último acesso em 02/10/2008.

Fig.E2 Elmo em bronze. Cnossos, Creta. Século XV a.C. Fonte da figura: $<$ http://www.salimbeti.com/micenei/helmets2.htm>. Último acesso em 02/10/2008.

Fig. E3 Detalhe de estatueta em bronze proveniente de Enkomi, Chipre. Heládico Recente IIIC. Fonte da figura: <http://www.salimbeti.com/micenei/helmets3.htm>. Último acesso em 20/10/2008.

Fig. E4 Detalhe da Face B do Vaso dos Guerreiros. Fonte da figura:

<http://www.salimbeti.com/micenei/helmets3.htm>. Último acesso em 20/10/2008.

Fig. E5 Ideograma em Linear B correspondente ao elmo. Fonte da figura:

$<$ http://www.salimbeti.com/micenei/helmets3.htm>. Último acesso em 20/10/2008.

Fig. E6 Elmo em bronze proveniente de Tirinto e sua reconstituição. Túmulo XXVIII. Cerca de 1050 a.C. Fonte da figura:<http://www.salimbeti.com/micenei/helmets3.htm>. Último acesso em 20/10/2008.

Fig. E7 Elmo e couraça (a mesma de AC4) em bronze proveniente de Argos. Cerca de 725 a.C.

Fonte da figura: $<$ http://www.windmillstravel.com/destination.php?type=city\&id=15>. Último acesso em 18/12/2008.

Fig. E8 Detalhe em perfil do elmo em E7. Fonte da figura:

$<$ http://flickr.com/photos/dandiffendale/2760928270/in/set-72157606707390236/>. Último acesso em $18 / 12 / 2008$.

\section{Prancha Escudo}

Fig. ES1 Adaga da Caça ao Leão, com representações do escudo 'em torre' e do escudo 'em oito' e do télamon. Proveniente do Túmulo em Poço IV, Micenas. 1550-1500 a.C. Museu Arqueológico Nacional de Atenas. Fonte da figura: $<$ http://www.salimbeti.com/micenei/shields1.htm $>$. Último acesso em 15/10/2008.

Fig. ES2 Dois discos (ônfalos) em bronze. Dimensões: $19 \mathrm{~cm}$ cada. Provenientes do Túmulo B7 de Mouliana, Creta. 1300-1200 a.C. Fonte da figura: <http://www.salimbeti.com/micenei/shields2.htm>. Último acesso em 15/10/2008.

Fig. ES3 Fragmento cerâmico de uma cratera. Proveniente de Micenas. Estilo IIIC. Cerca de 1200

a.C. Fonte da figura: <http://www.salimbeti.com/micenei/shields2.htm>. Último acesso em 19/10/2008.

Fig. ES4 Fragmento cerâmico Proveniente de Tirinto. Cerca de 1250 a.C. Fonte da figura:

$<$ http://www.salimbeti.com/micenei/shields2.htm>. Último acesso em 19/10/2008. 
Fig.ES5 Fragmentos em bronze acompanhados de três ônfalos $(16,2 \mathrm{~cm} ; 8,4 \mathrm{~cm}$ e $8,4 \mathrm{~cm})$. Provenientes do túmulo 40, Kaloriziki (Kurion), Chipre. Fonte da figura:

$<$ http://www.salimbeti.com/micenei/shields3.htm>. Último acesso em 02/10/2008.

Fig. ES6 Fragmento de uma cratera ática mostrando uma figura portando um escudo em forma de ampulheta entre dois arqueiros. Proveniente do cemitério do Dípilon, Atenas. Metade do século VIII a.C. Louvre, Paris, A530 [s488]. Fonte da figura:

<http://upload.wikimedia.org/wikipedia/commons/f/f7/Warriors Dipylon Master Louvre S523.jpg>. Último acesso em 20/10/2008.

\section{Prancha Espadas}

Fig. ESP1 Algumas das espadas, dentre outros achados, encontradas no Círculo Tumular A em Micenas expostas numa vitrine do Museu Arqueológico Nacional de Atenas. Fonte da figura: concessão do acervo pessoal de Gilberto da Silva Francisco.

Fig. ESP2 Duas espadas micênicas. Segunda metade do século XVI a.C. Museu Arqueológico Nacional de Atenas. Foto Y. Fafalis. Fonte da imagem: Les Myceniens: Des Grecs du lle millénaire, Editions Fatons, Dijons, 1994 (obra coletiva), p. 29.

Fig. ESP3 Tablete em Linear B que apresenta o ideograma para a espada. Fonte: Chadwick, p.173.

\section{Prancha Lança e Dardo}

Fig. LD1 Pontas de lanças. Fonte: Courbin, em Vernant, 1968, pl.2.

\section{Prancha Arco e Flecha}

Fig. AF1 Anel-sinete em ouro com cena de caça em que o arqueiro é representado com um arco. Proveniente do Túmulo em Poço IV no interior do Círculo Tumular A. Micenas.

Cerca de 1550-1500 a.C.

Fonte da figura: <http://www.salimbeti.com/micenei/chariots.htm>. Último acesso em 03/12/2008.

Fig. AF2 Fragmento de ríton em prata proveniente do Túmulo em Poço IV no interior Círculo Tumular A. Micenas. Cerca de 1550-1500 a.C. Fonte: Stubbings, 1973, p. 28, fig. 26a e 26b.

\section{Prancha Carro}

Fig. CA1 Estela funerária encontrada por Schliemann no Túmulo em Poço V do Círculo Tumular A, Micenas. 1550-1500 a.C. Museu Arqueológico Nacional de Atenas, número de inventário 1427. Fonte da figura: acervo pessoal de Gilberto da Silva Francisco.

Fig. CA2 Estela funerária encontrada por Schliemann no Túmulo em Poço V do Círculo Tumular A, Micenas. 1550-1500 a.C. Museu Arqueológico Nacional de Atenas, número de inventário 1428. Fonte da figura: acervo pessoal de Gilberto da Silva Francisco.

Fig. CA3 Estela funerária encontrada por Schliemann no Túmulo em Poço V do Círculo Tumular A, Micenas. 1550-1500 a.C. Museu Arqueológico Nacional de Atenas, número de inventário 1429. Fonte da figura: acervo pessoal de Gilberto da Silva Francisco.

Fig. CA4 Miniatura de uma biga encontrada na Tessália, datada do século XIII a.C. Fonte da figura: $<$ http://www.salimbeti.com/micenei/chariots.htm>. Último acesso em 22/12/2008.

Fig. CA5 Esquema de um tablete em Linear B proveniente de Cnossos com o ideograma para o carro. Fonte da figura: <http://www.salimbeti.com/micenei/chariots.htm>. Último acesso em 22/12/2008.

\section{Figura da epígrafe do Capítulo 5}

Tirinha intitulada "Now Showing", criada por um artista de Nova York e publicada no website denominado "Perry Bible Fellowship" Comic Strips. Fonte: http://pbfcomics.com/?cid=PBF209Now Showing.jpg. Último acesso em 12/11/2008. 


\section{Lista de Websites}

Página sobre armamento micênico:

http://www.salimbeti.com/micenei/index.htm

Página oficial do quadrinho Age of Bronze de Eric Shanower:

http://age-of-bronze.com/aob/index.shtml

Fórum de discussão sobre a Idade do Bronze:

http://s8.invisionfree.com/Bronze Age Center/

Página do Project Troia da Unversidade de Tübingen:

http://www.uni-tuebingen.de/troia/eng/index.html

Página do Perseus Project:

http://www.perseus.tufts.edu/cache/perscoll Greco-Roman.html 


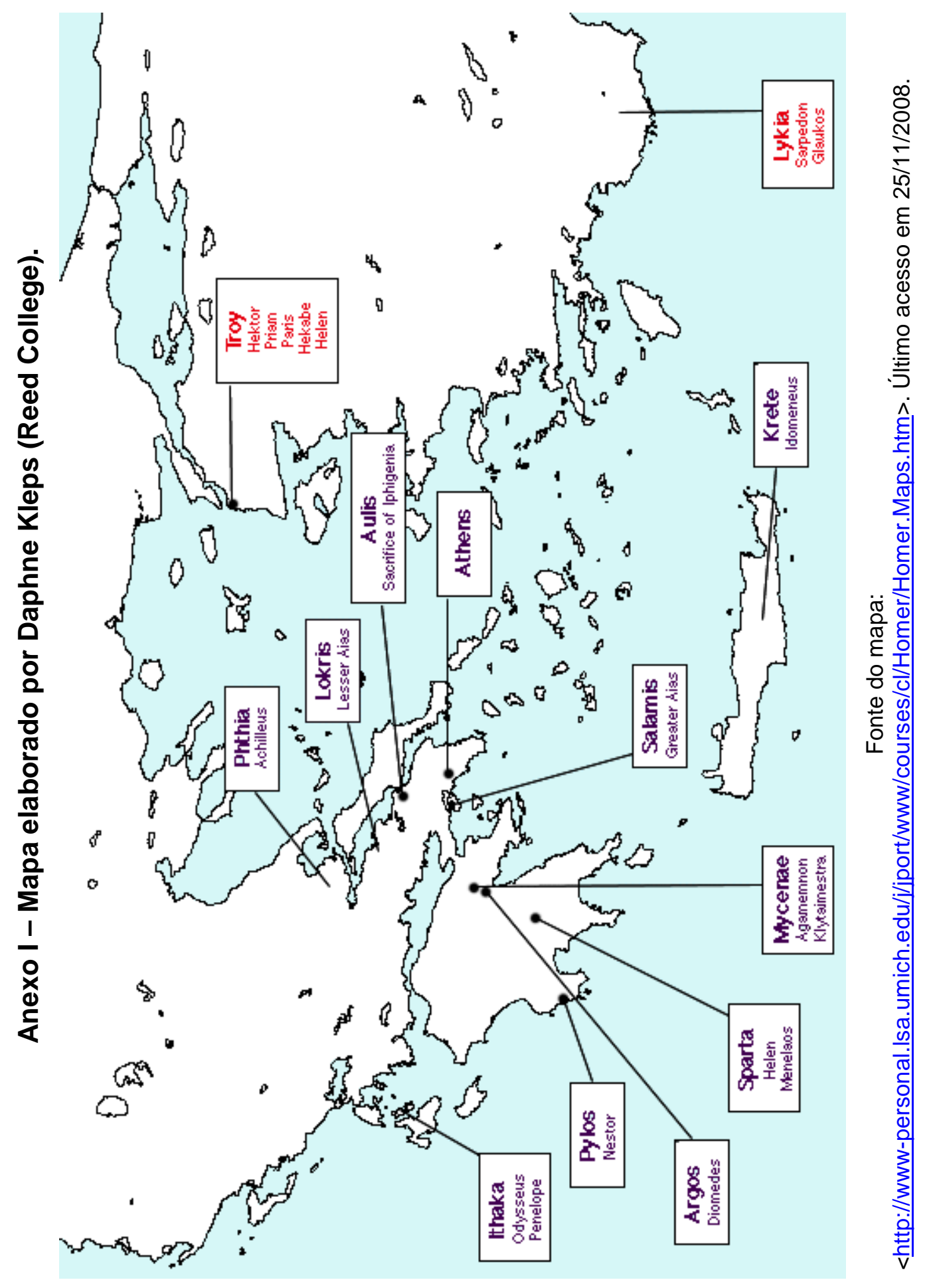




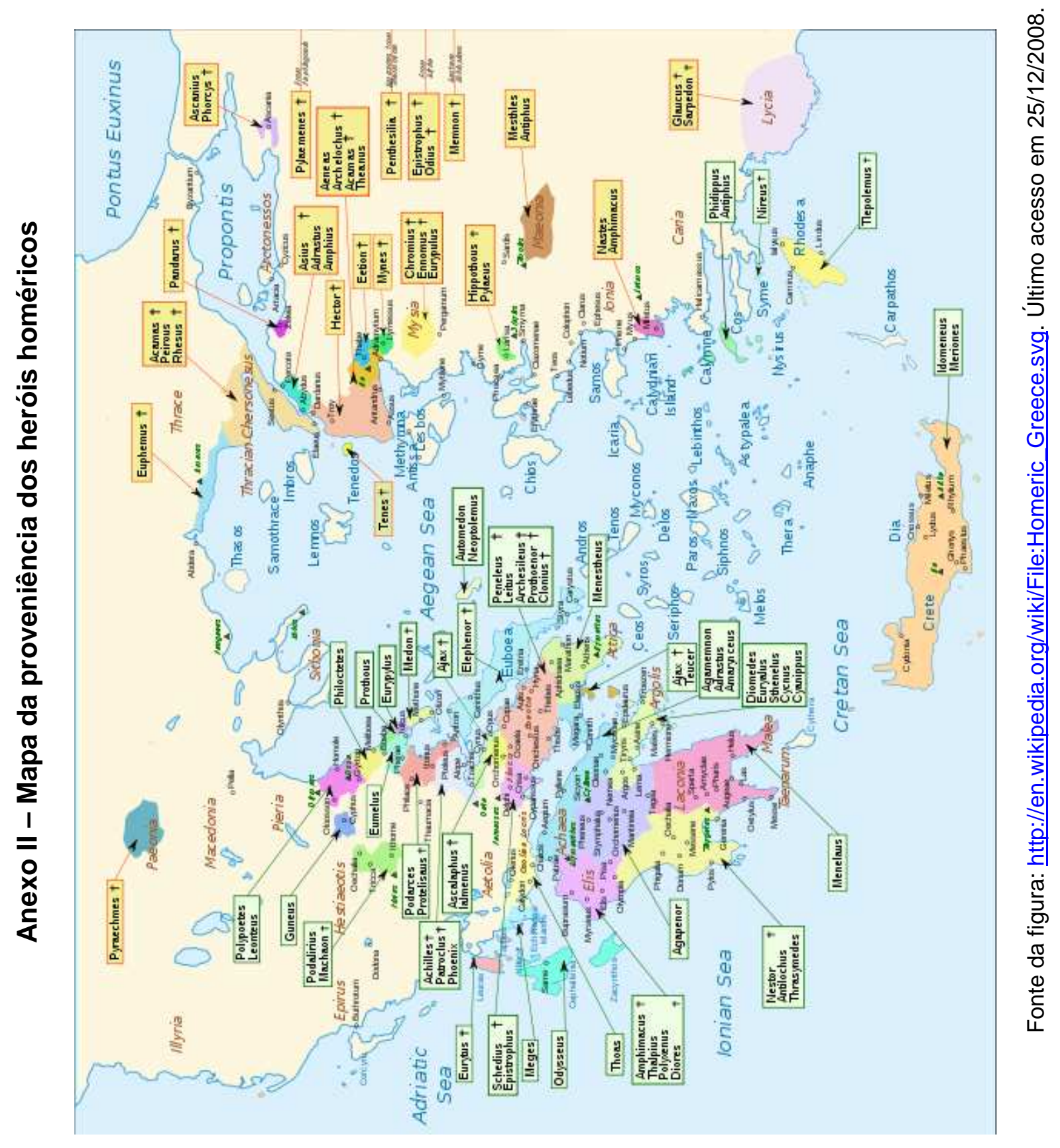


Anexo III - Sítios datados da Idade do Bronze que apresentam palácios

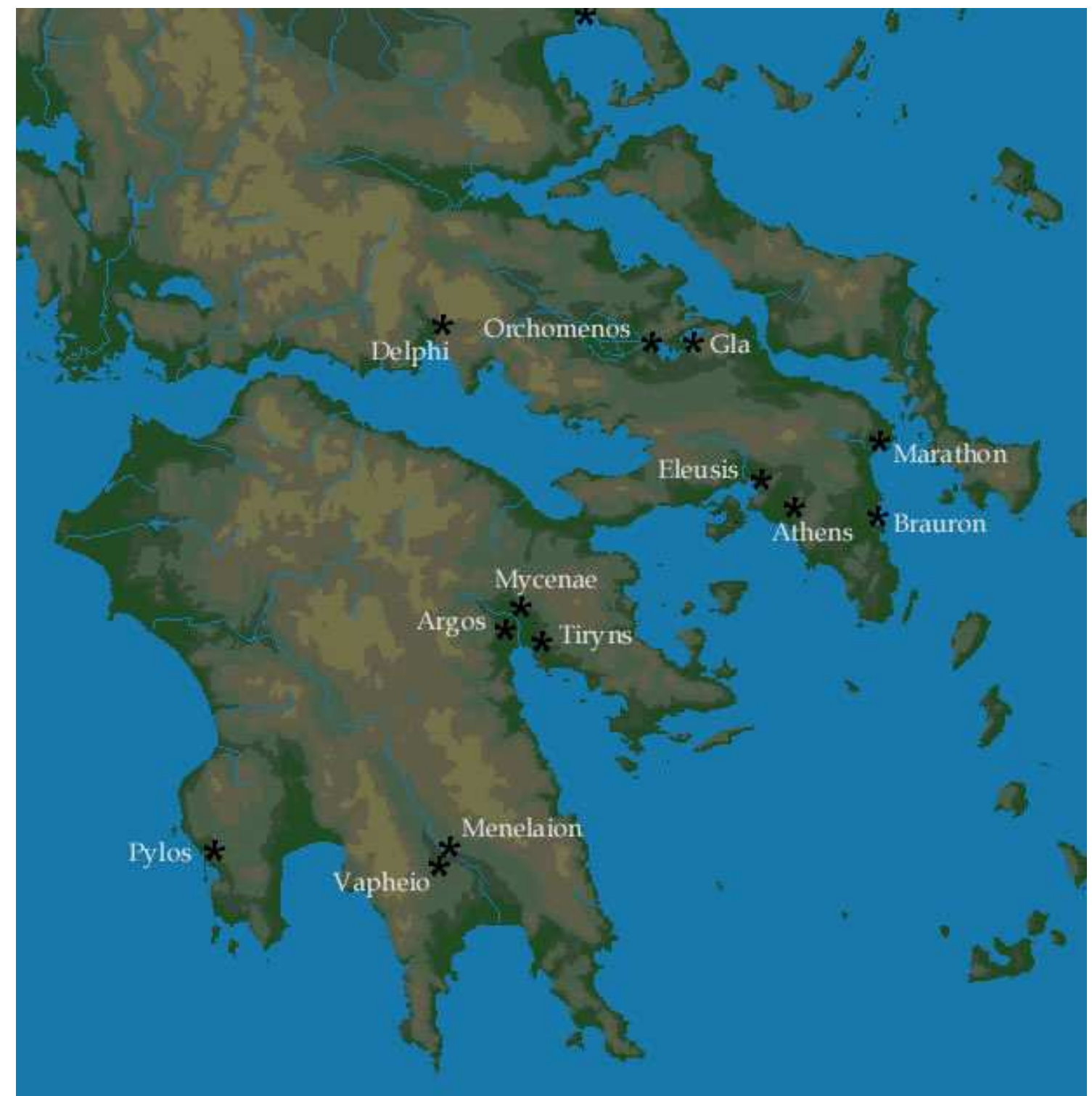

Fonte da figura: http://www.odysseyadventures.ca/articles/mycenae/Map Greece.htm. Último acesso em 14/12/2008. 
ANEXO IV - Tabela Cronológica

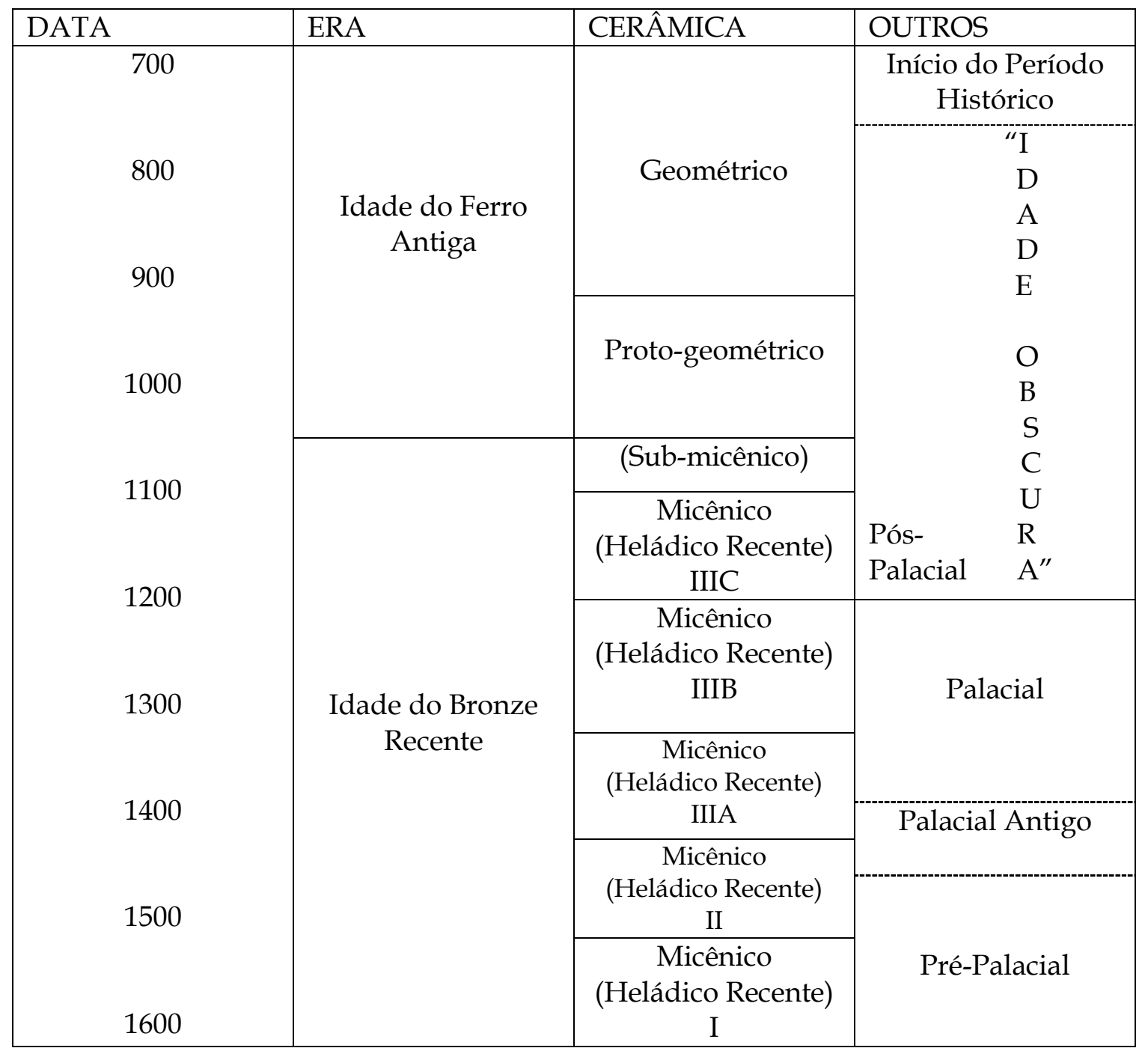

Fonte da Tabela: SHERRAT, 1990, p. 809. (Tradução Própria) 